$$
\text { الأحاديث الواردة في }
$$$$
\text { جمعاونخريجا وصر|سة }
$$$$
\text { إعداو الركثور }
$$

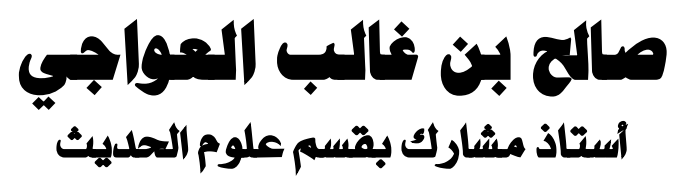

بكلية الحديث الشريف بالجامعة الإسلامية

\title{
ov äliuso
}

حولية كلية أمول الديه والدعوة بالمنوفِية

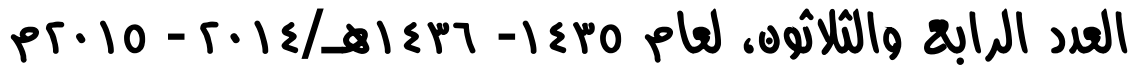

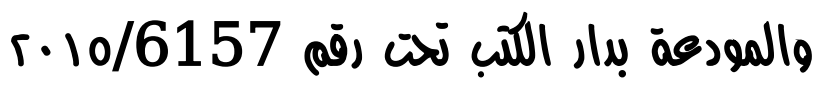




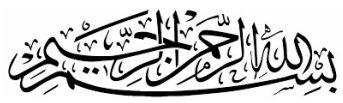

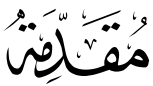

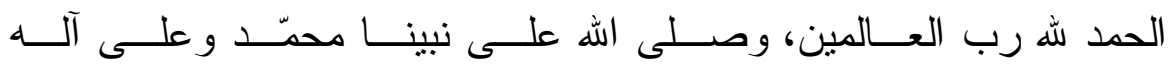
وصحبه أجمعين، وبعد:

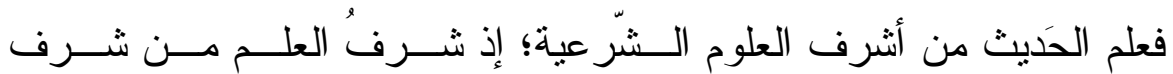

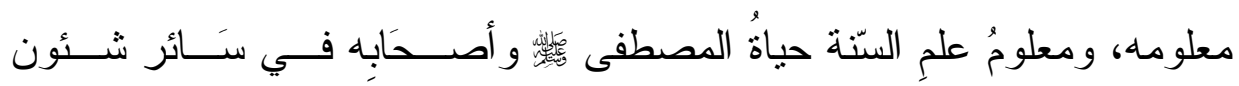

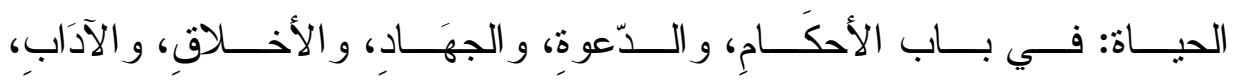
و المعَاملات، و غير هَا.

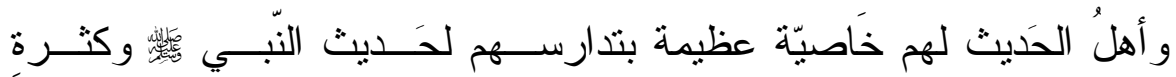

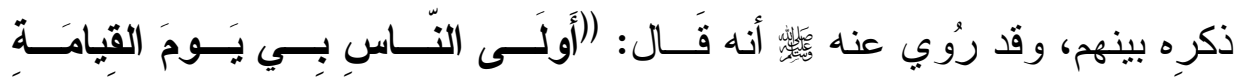

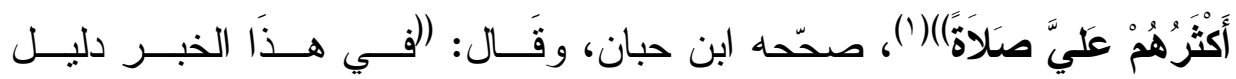

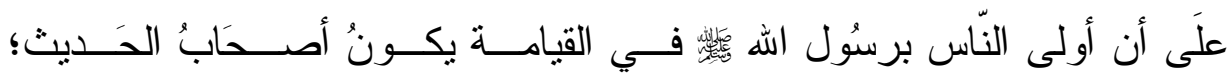

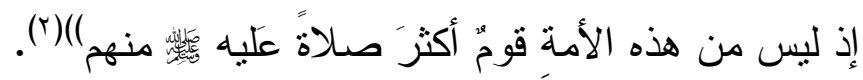

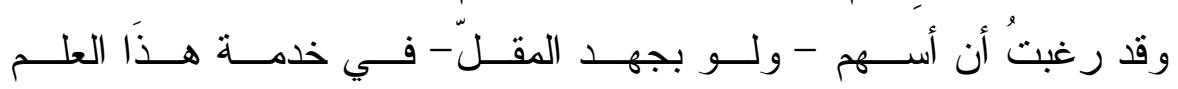

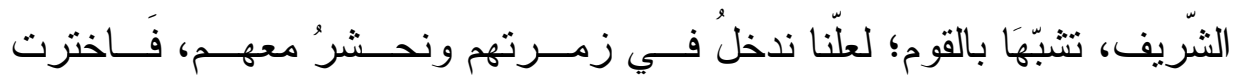

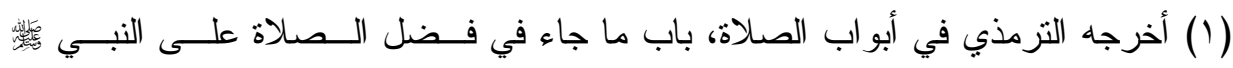

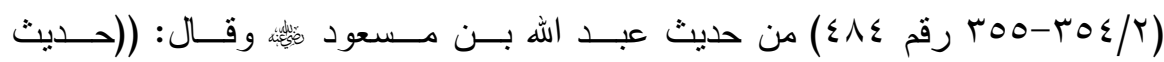

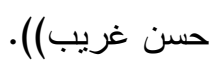

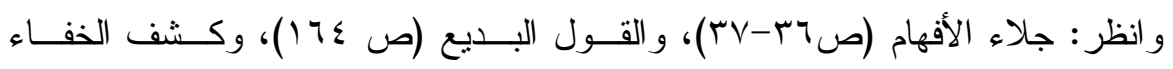

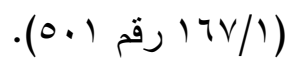

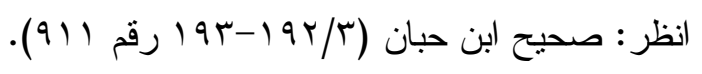




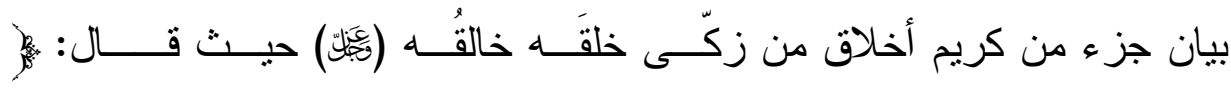

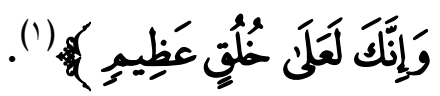

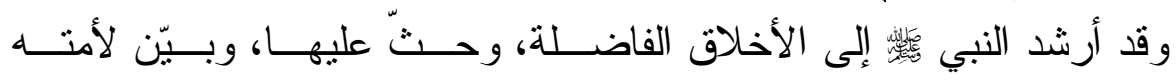
عظيم أجر أهلها في أحاديث كثيرة، ومن ذلك:

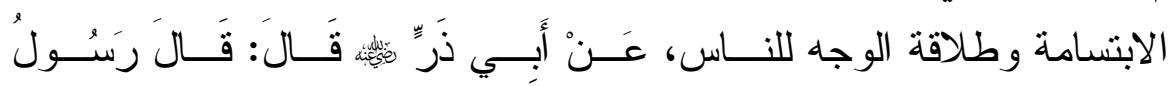

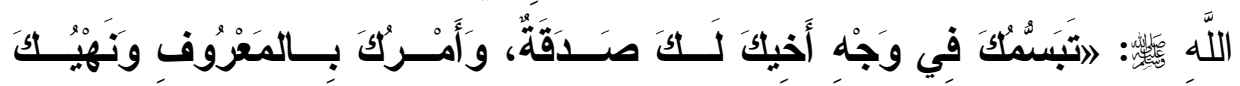

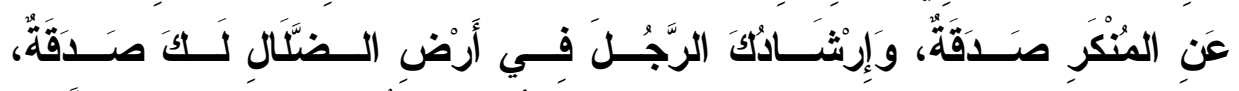

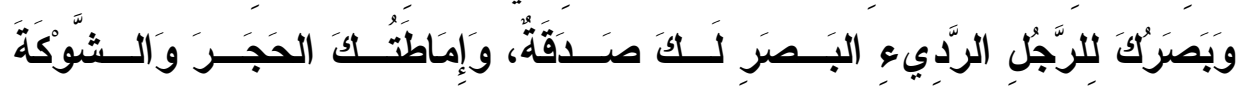

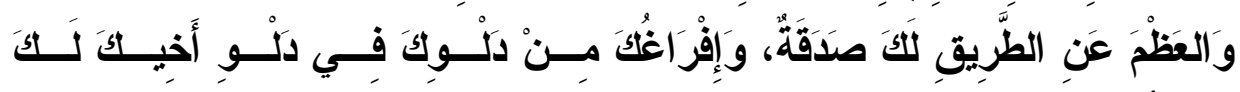

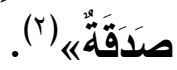

وكان تعامله

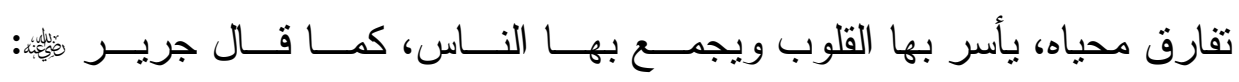

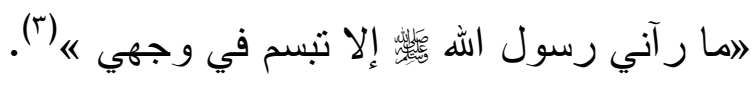

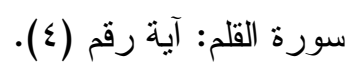

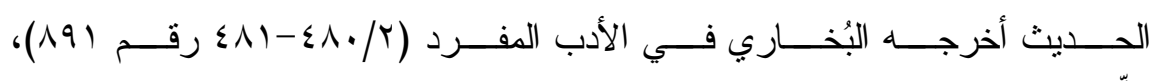

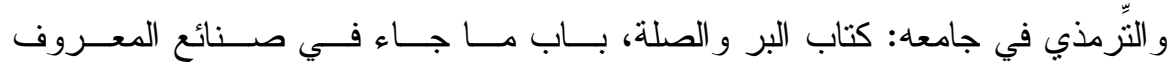

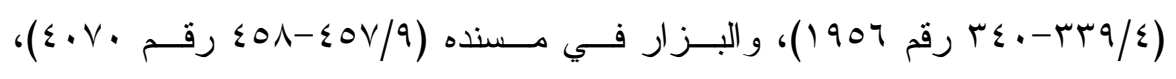

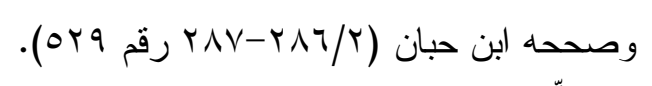

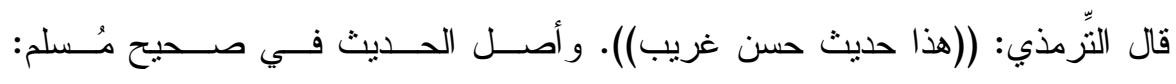

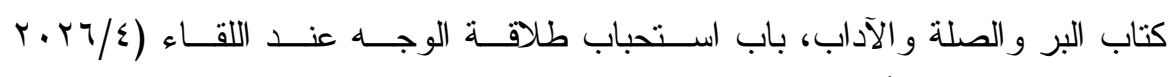

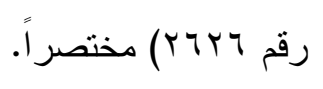

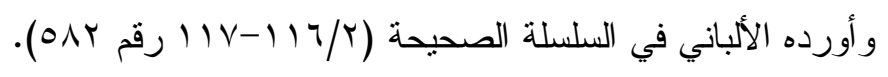

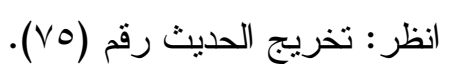


وهذا البحث يتعلق موضو عه بذلك الجانب المشرق، و الخلق الرفيع.

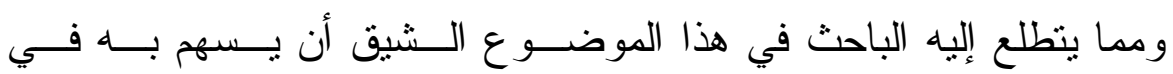

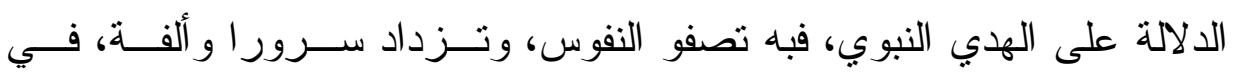

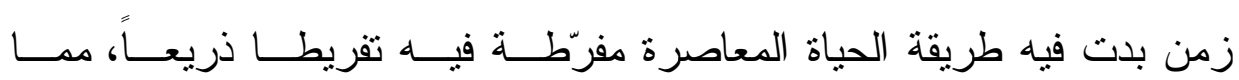
تتسبب لبعضهم في أمر اض مزمنة، و اكتئاب قد يصعب العلاج منه.

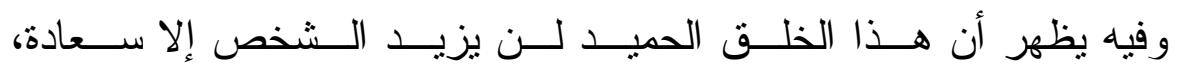

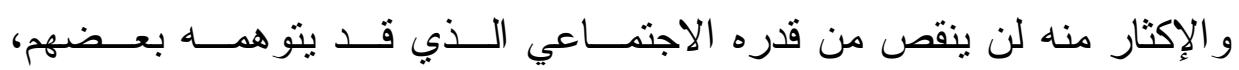

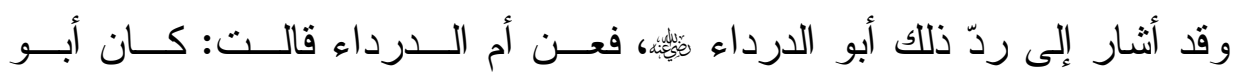

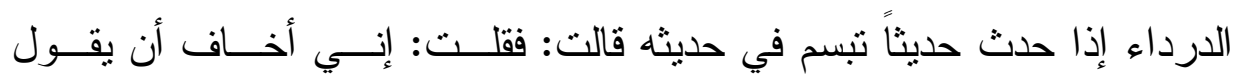

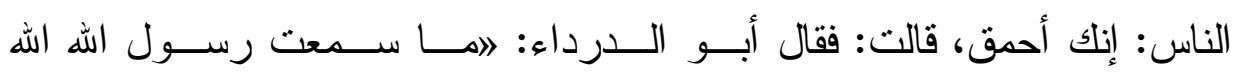
(') (

\section{أهمية البحث وأسباب اختياره:}

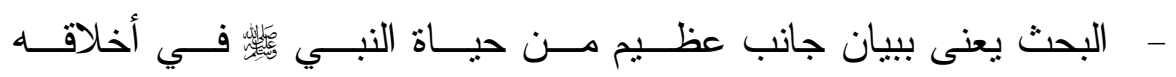

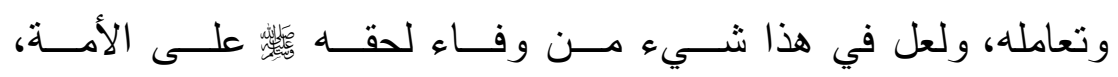
وتعظيم قدره.

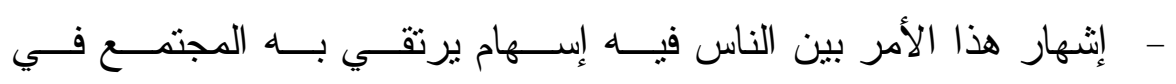

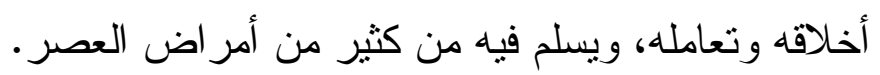

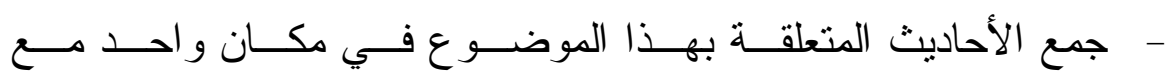
تخريجها ودر استها، وبيان الــصحيح منهـــا معـين لمــن أر اد نـشـر سماحة الإسلام و الدعوة إليه، و إظهار ذلك للبشرية جمعاء. 
مما تقدم في بيان أهمية الموضوع من أســباب مجتمعـة تظهـر أسـباب اختيار موضوع هذا البحث.

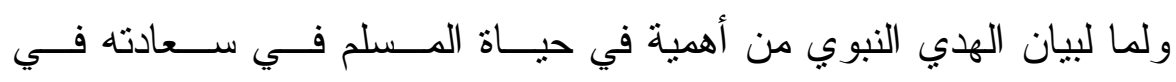

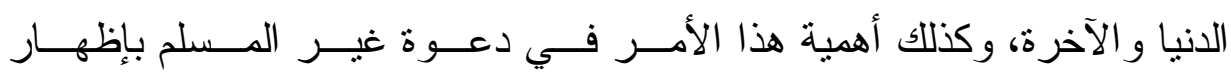

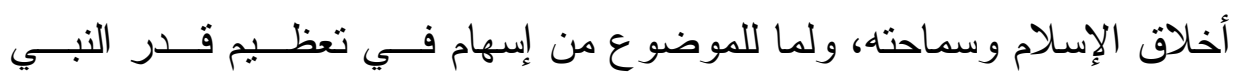

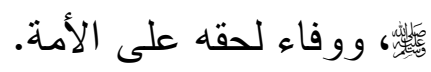

\section{أهداف البحث:}

- - جمع الأحاديث المتعلقة بموضو ع البحث في مؤلف و احد. -

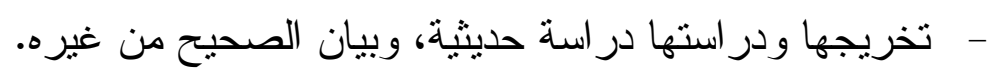

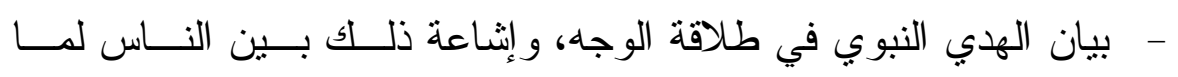

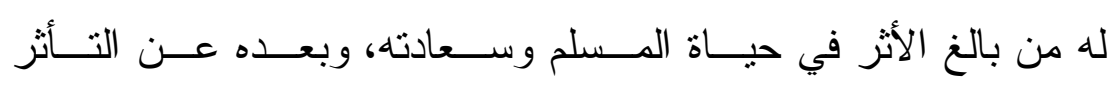

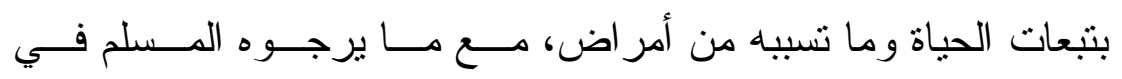
الآخرة من الأجر الوفير .

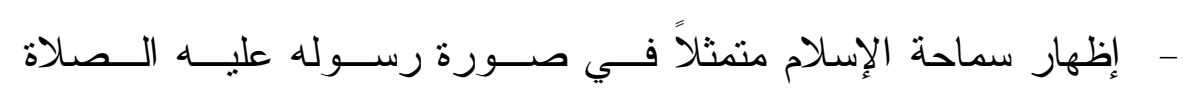

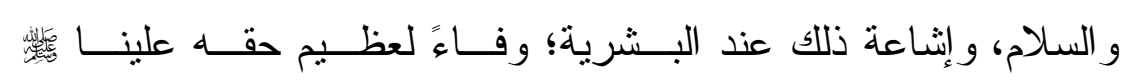
ودعوة لدينه.

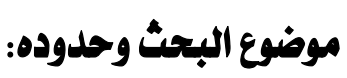

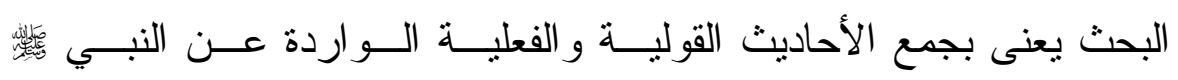

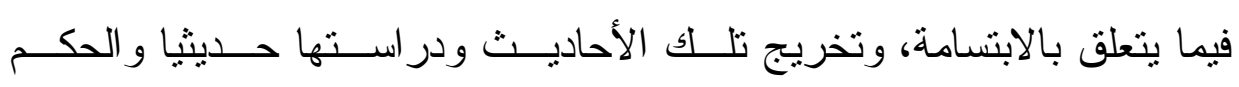
عليها.

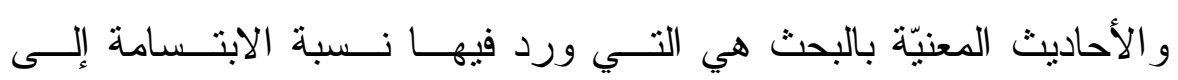

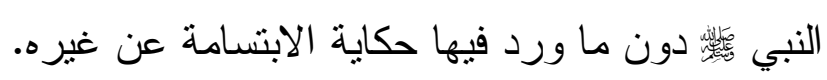


وجمع الأحاديث سيكون من الكتب التالية: - الكتب التسعة: صحيح البُخاري ومسلم، وســنـ أبــي داود و النـسائي

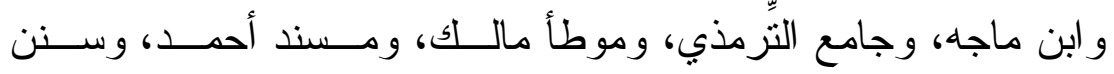

$$
\text { الدارمي. }
$$

- المنتقى لابــن الجـارود، وســنـ الــدر اقطني، ومعــاجم الطبرانـي الثثلاثة، و السن الصغرى و الكبرى وشعب الإيمان للبيهقي. - - محيحي ابن خزيمة و ابن حبان ومستدرك الحاكم. - مسانيد الطاليسي، و الحميدي، و إسحاق، و أبي يعلى، و البزار . - مصنفي عبد الرز اق و ابن أبي شيبة.

\section{الدراسات السابقة: - (الد}

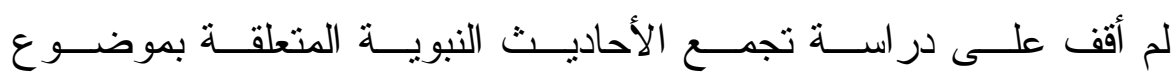

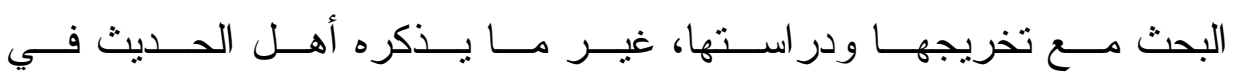
مصنفاتهم في أبو اب الآداب ونحو ذلك، كما صــنع الإمــام البُخـــاري رحمـــهـ

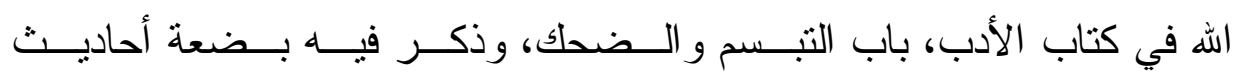

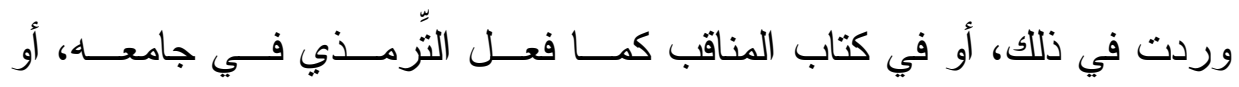
المصنفون في الثمائل و السير كصنيع التِّرذي أيضاً في شمائله.

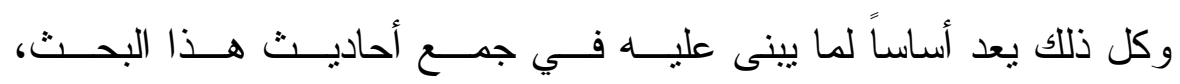
ومسائله.

ومما يحسن الإشارة إليه هنا:

رسالة لأحمد بن الصديق الغماري بعنـــوان: (ثــــوارق الأتــــوار المنيفــة بظهور النو اجذ الثريفة). 


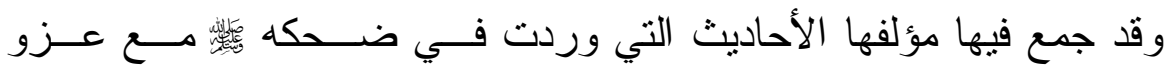

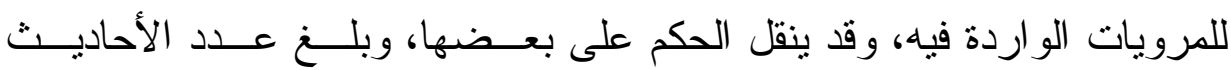
لديه (9 (1) حديثًا.

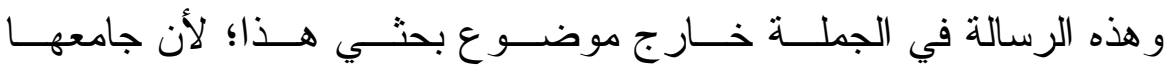

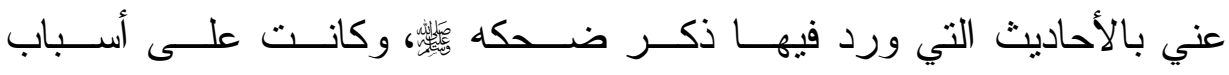
ووقائع معينة وليس في ابتسامته.

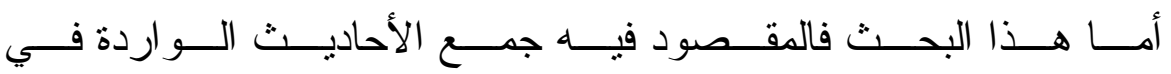

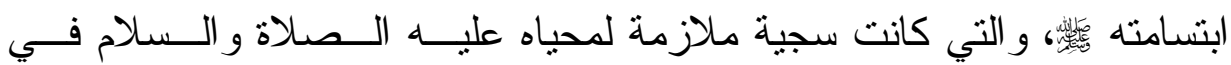
غالب أحو اله، أو عند حصول ما يقتضيها ('). وبلغ عندي عدد الأحاديث ثمانين ( • (^) حديثًا.

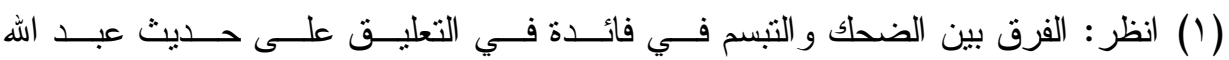
بن الحارث بن جَز عقب تخريج الحديث رقم (•) (م). 
خطة البحث:

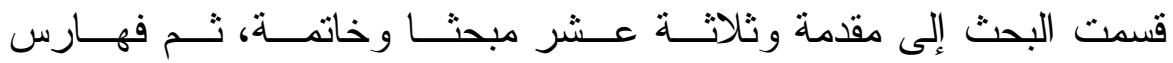

علمية.

المقدمة: وتحتوي على أهميــة الموضــوع وســبب اختيــاره، و الخطـــة،

و المنهج.

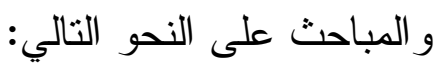

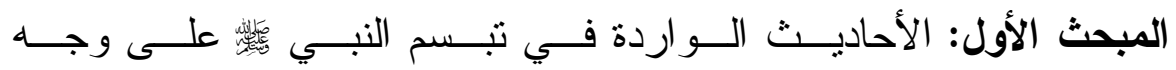

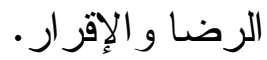

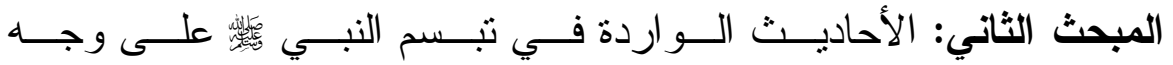

التفاؤل و البشارة.

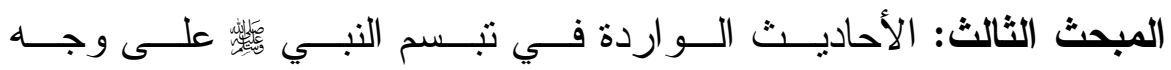

النصر و التمكين.

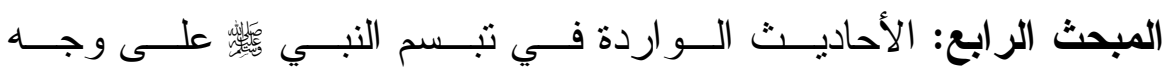

الماطفة و الانبساط.

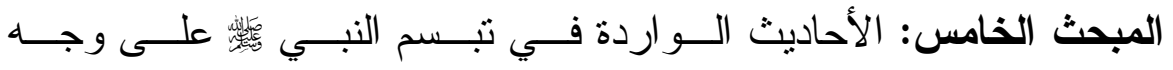

التعجب.

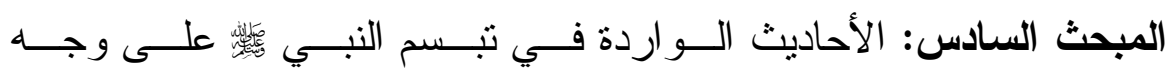

الغضب.

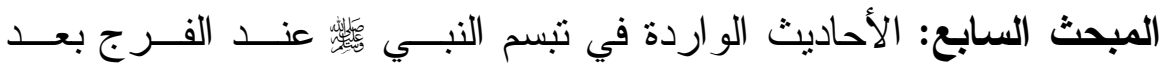

الثدة.

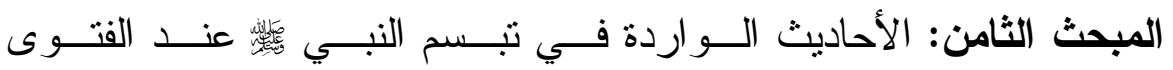




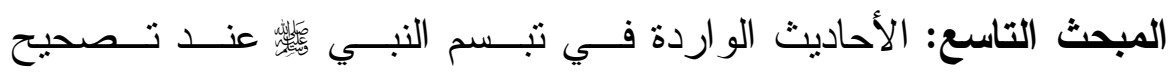
الخطأ وبيان الصو اب. - ابع.

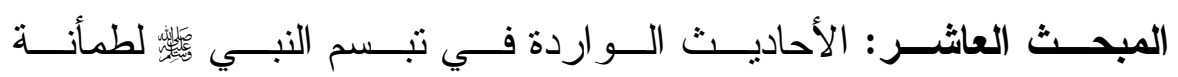
المتخوف.

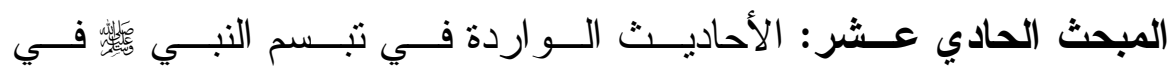

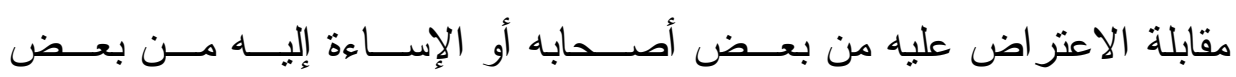

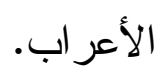

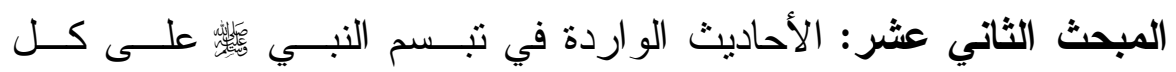

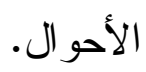

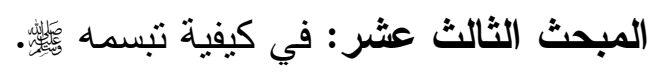
الخاتمة: وفيها أهم نتائج البحث. ثبت المصادر و المر اجع. الفهارس العلمية.

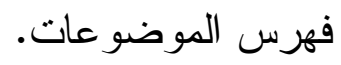

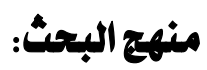

وقد راعيت في المنهج الذي سرت عليه في هذا البحث ما يلي:

- - جمع الأحاديث الواردة في هذا الموضوع من الكتب التالية:

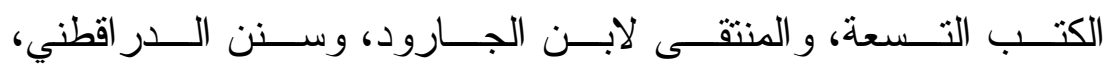

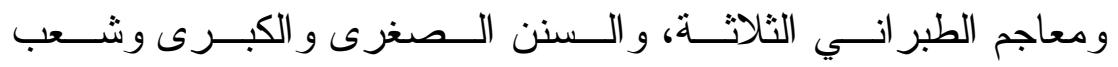
الإيمان للبيهقي. وصحيحي ابـن خزيمسـة وابـن حبــان ومسـستدرك

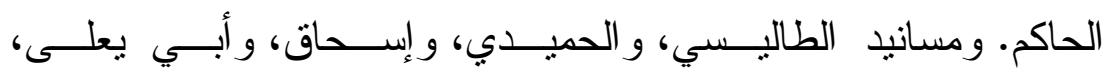
و البزار .ومصنفي عبد الرزاق و ابن أبي شيبة. 
- أقتصر في جمع الأحاديث على ما ورد فيه التـصريح بلفــ التبـسم وما اشتق منه.

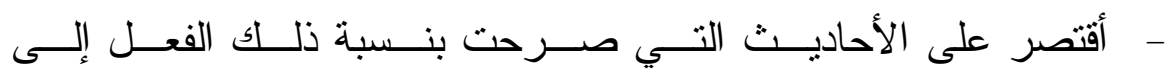
النبي

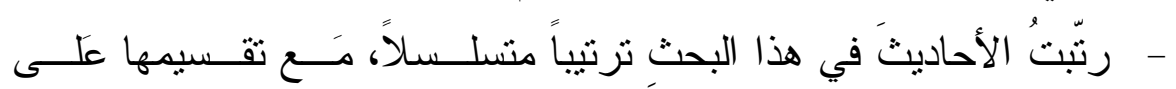

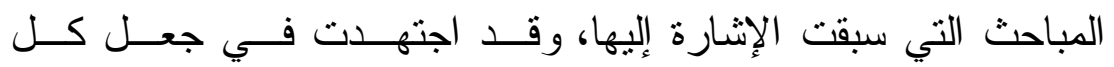

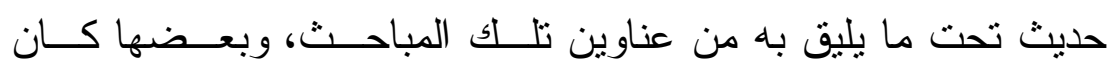

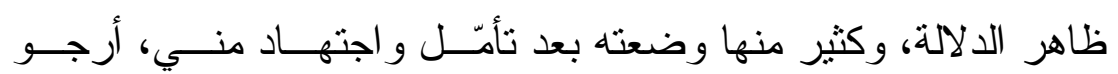
أن أكون قد وفقت فيه، و الله أعلم.

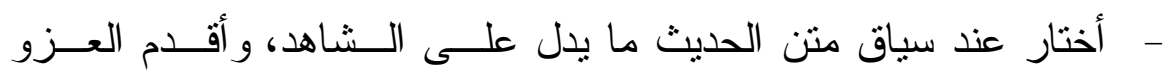
له كذللك عند التخريج. - - إذا كان الحديث طويلا فأقتصر منه على مـــا يبـين موضـــع الـشـاهد للبحث.

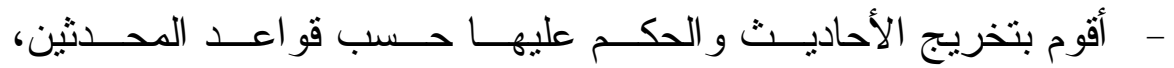

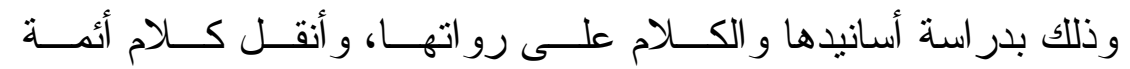

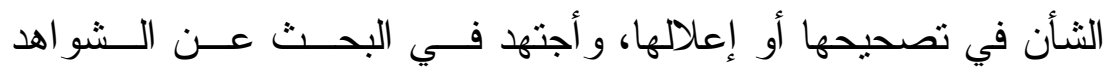
إن استذعى المقام ذلك. - لا أستطرد في ذكر من أخــرج الحــديث مــالم تكــن ثـــت هنــاك حاجة، مع سهولة ذلك مع الموسوعات الحديثة. - أهتم حين تخريج الحديث بما يدل على الثاهد منه.

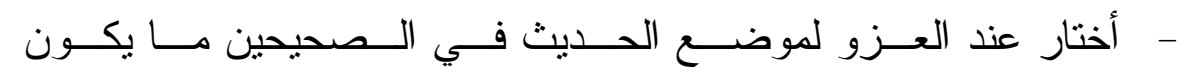
مناسباً لموضع البحث من تلك المو اضع. 
- ـ إذا وردت ألفاظ أخرى للحديث بغيــر لفـــ التبـسم، مثــل: الــضحك

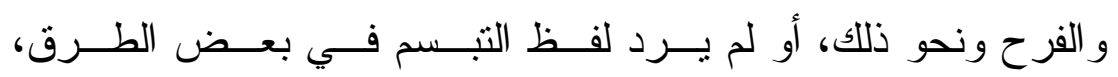

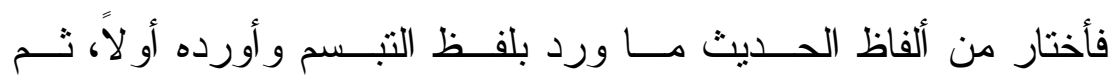
أورد الألفاظ الأخرى التي وردت فيــهـه وأثـــير إلـى مــن أخرجهــا،

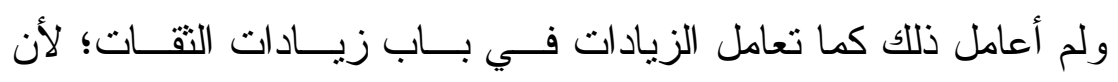

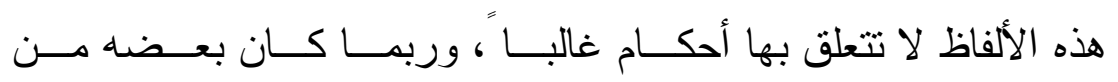

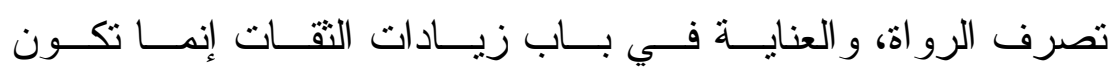

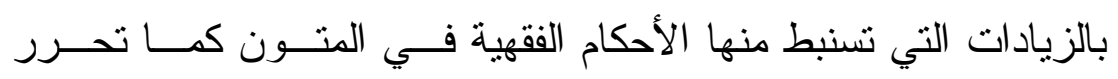

$$
\begin{aligned}
& \text { في علوم الحديث ('). } \\
& \text { - أقوم بشرح الغريب. } \\
& \text { - أعلق على ما يحتاج إلى تعليق. }
\end{aligned}
$$

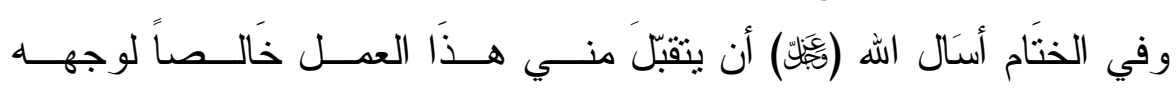

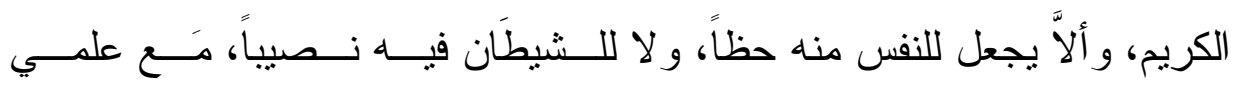

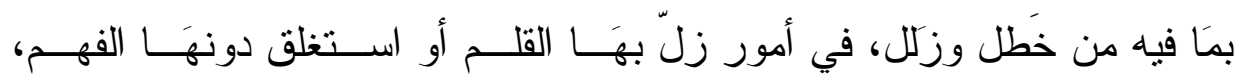

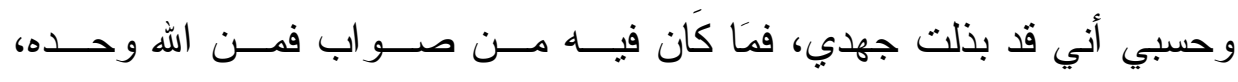

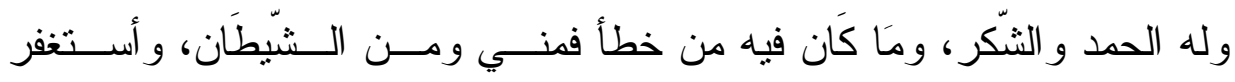
الله العظيم.

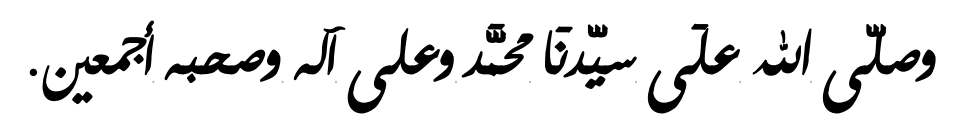

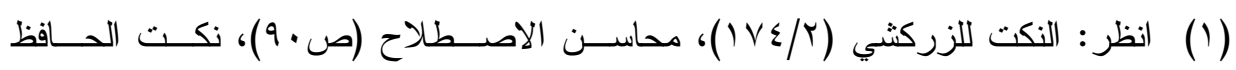

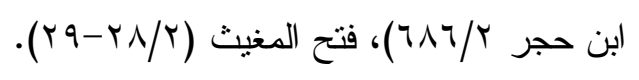




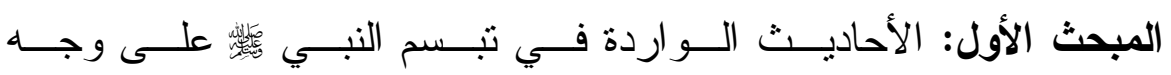

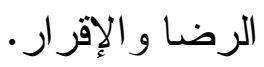

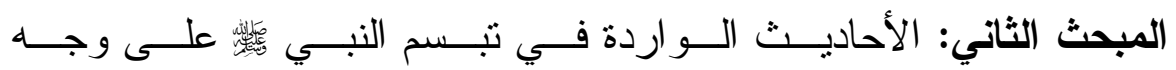

التفاؤل و البشارة.

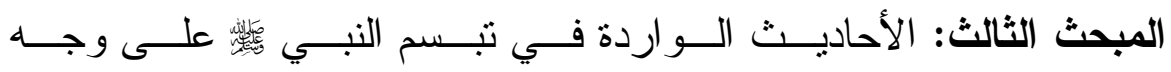

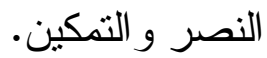

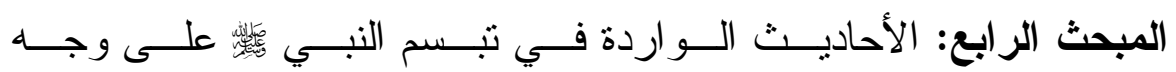
الماطفة و الانبساط.

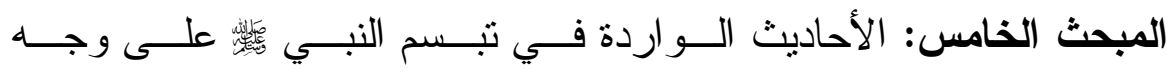
التعجب.

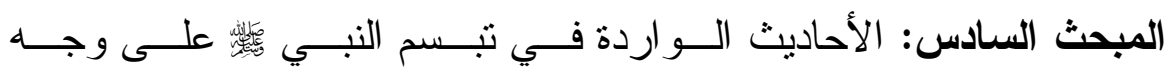

$$
\text { الغضب. }
$$

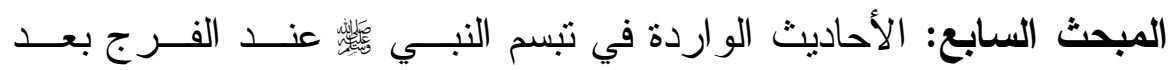

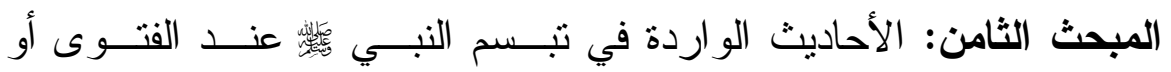
الحكم.

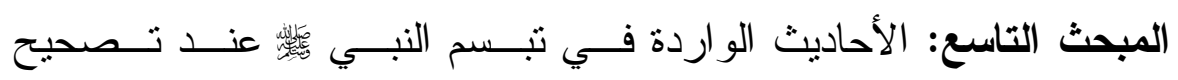
الخطأ وبيان الصو اب. - ابع.

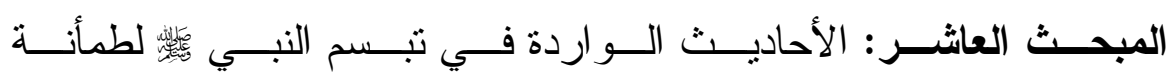

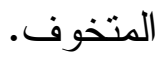




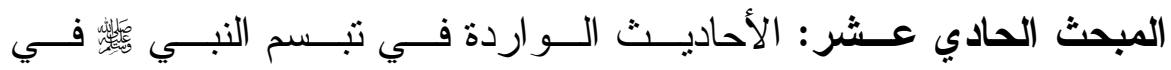

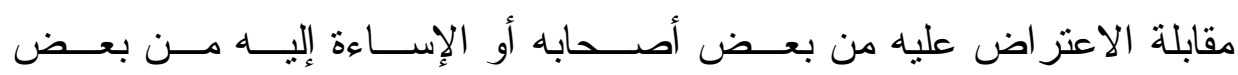

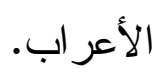

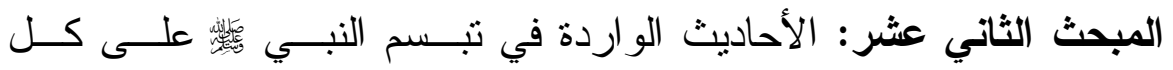

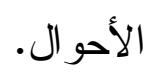

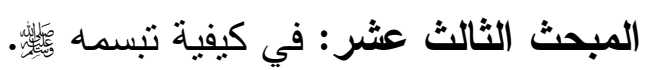




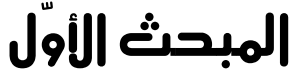

\section{الأحاديث الواردة في تبسم النبي المبد على وجه الرضا والإترار}

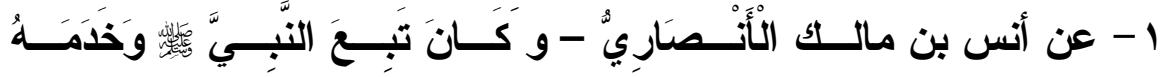

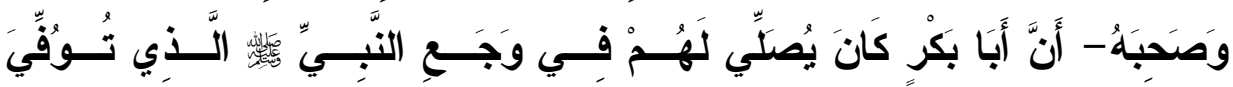

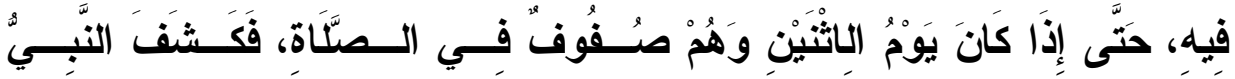

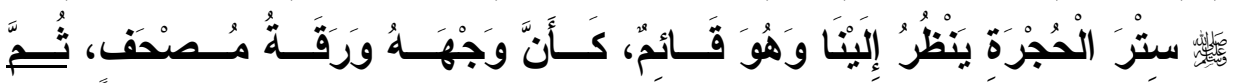

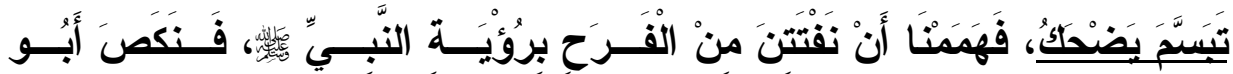

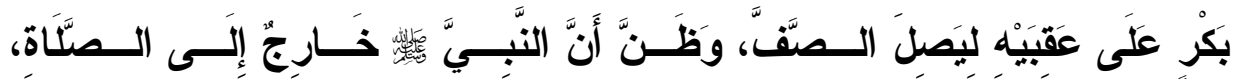

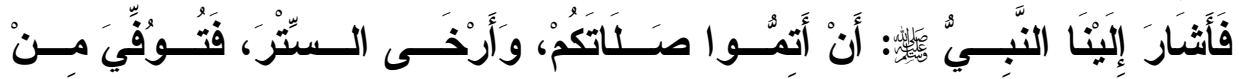

\section{تخريج الحديث:}

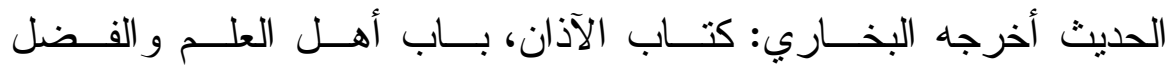

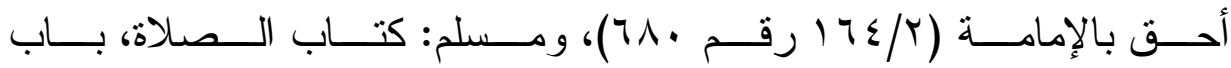

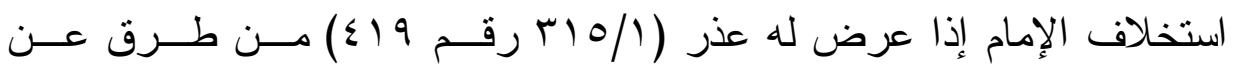
الزهري عن أنس فئس

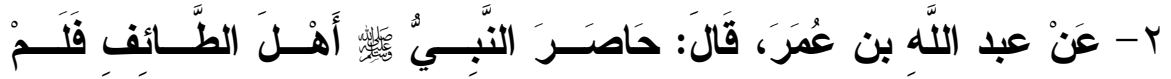

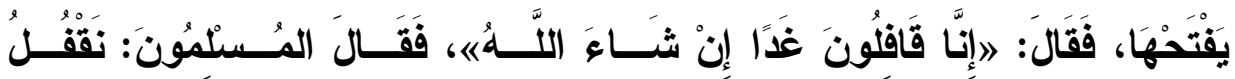

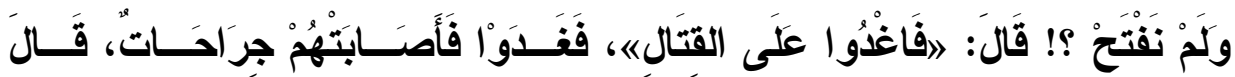

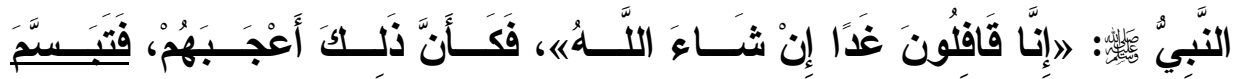

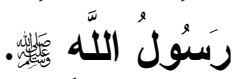




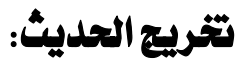

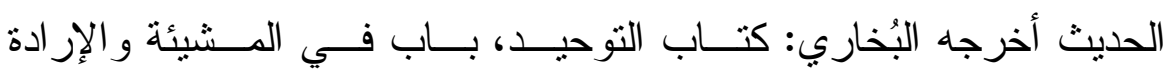

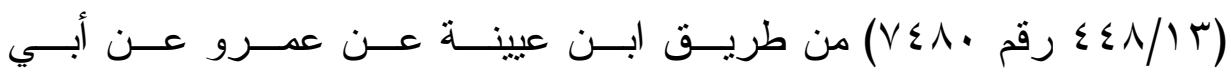

$$
\text { العباس عن ابن عمر (خفلّمنما). }
$$

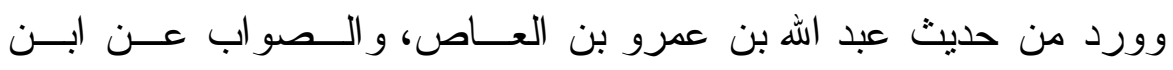

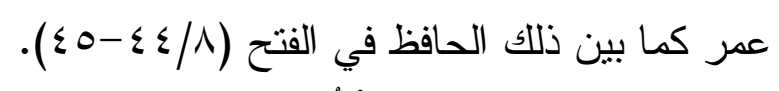

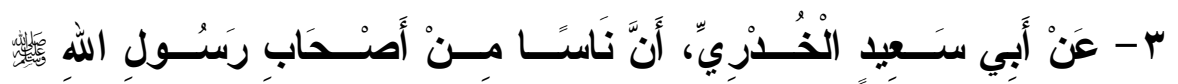

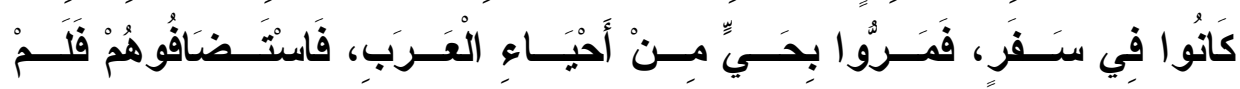

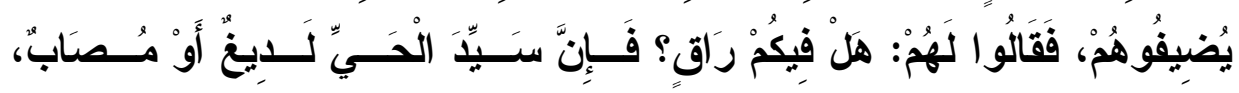

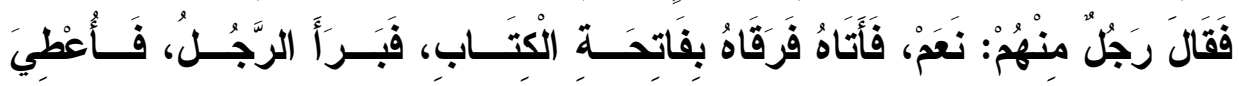

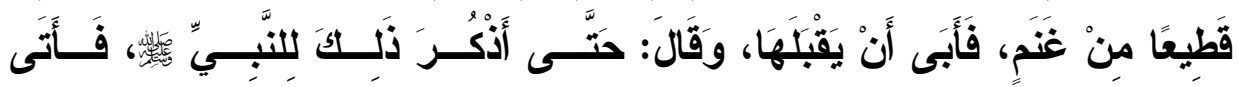
النَّبَّيَّ

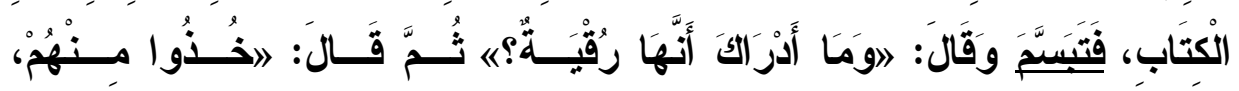

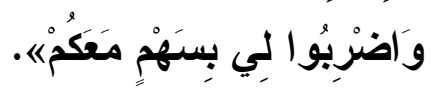

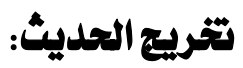

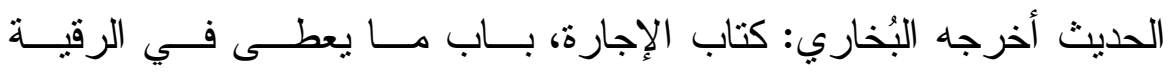

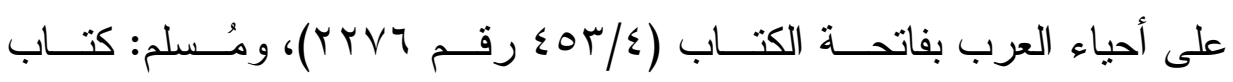

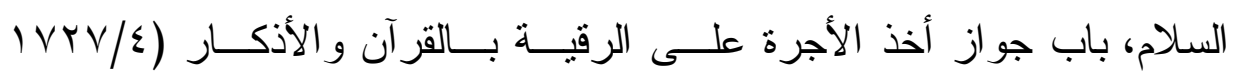

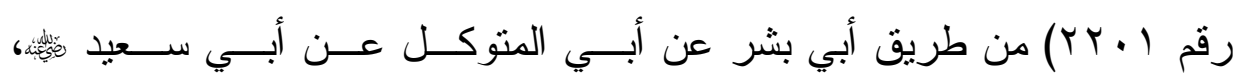

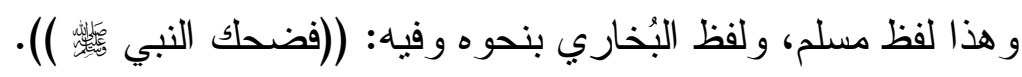




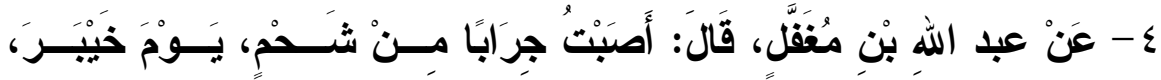

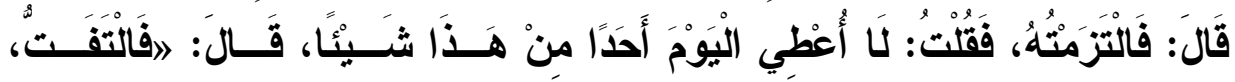

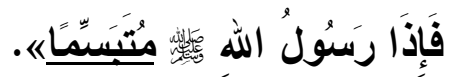

\section{تقريج الحديث:}

الحديث أخرجه مُسلم: كتاب الجهاد و الــسير، بــاب جـــواز الأكــل مـــن

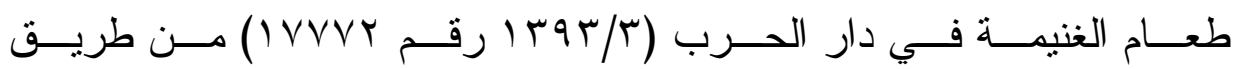
سليمان بن المغيرة عن حميد بن هلا عن عبد الهه بن مغفل. و أخرجه البُخاري: كتاب فرض الخمس، باب مـــا بــصيب مــن الطعـام

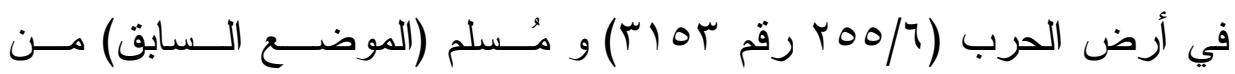
طريق شعبة عن حميد به، لكن ليس فيه ذكر التبسم.

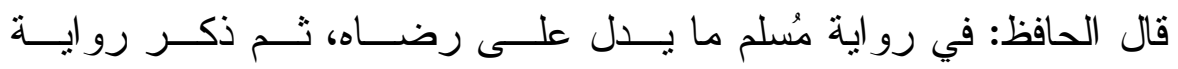

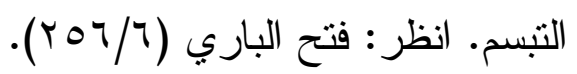

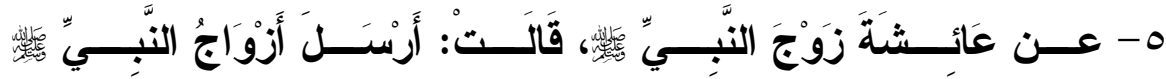

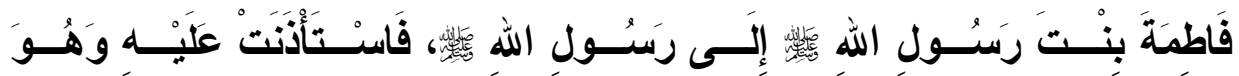

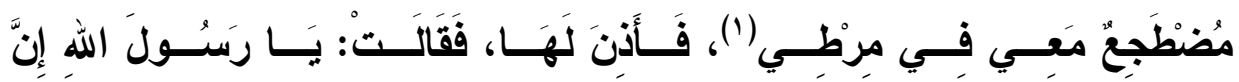

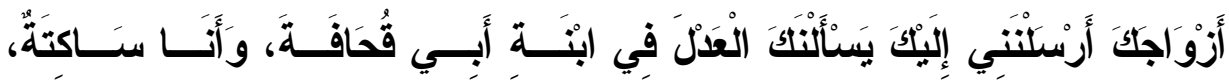

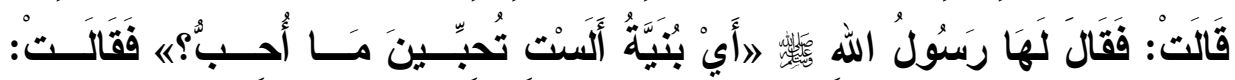

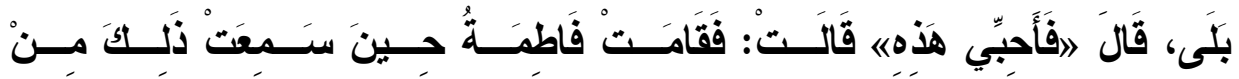

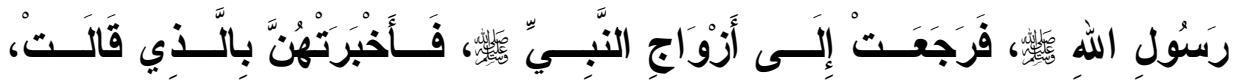

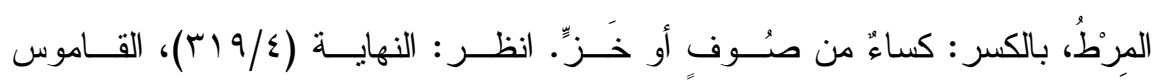

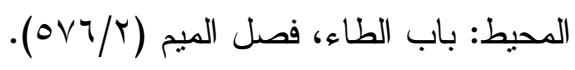




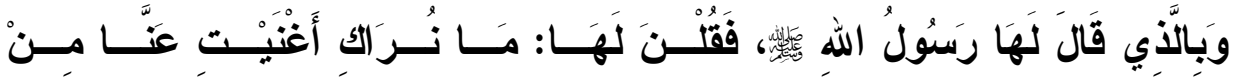

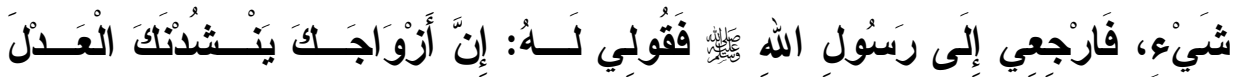

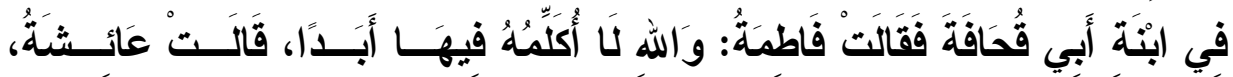

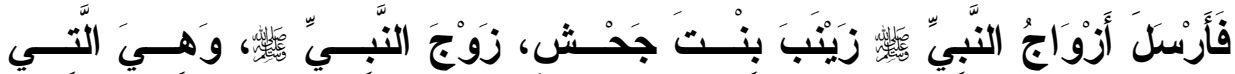

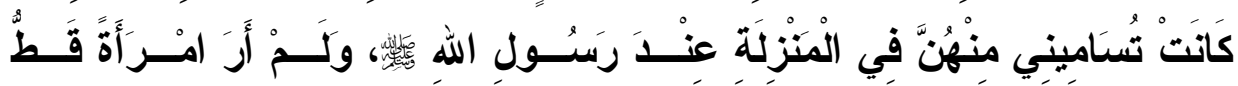

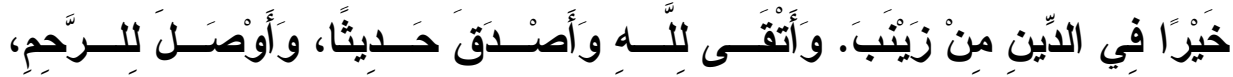

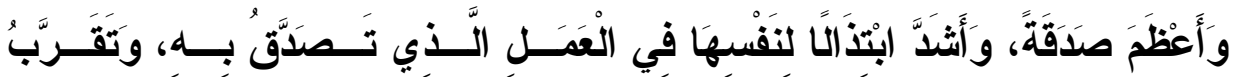

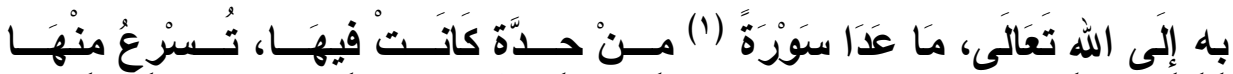

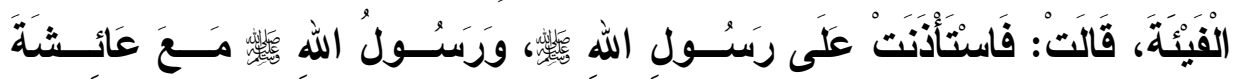

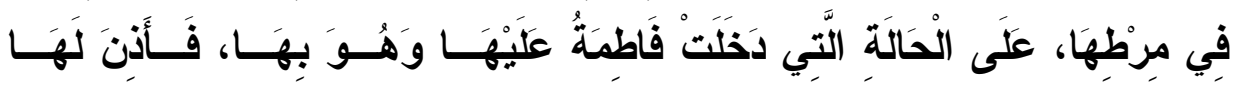

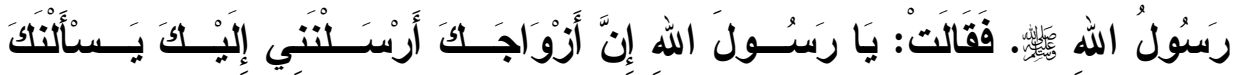

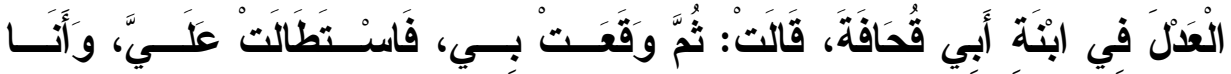

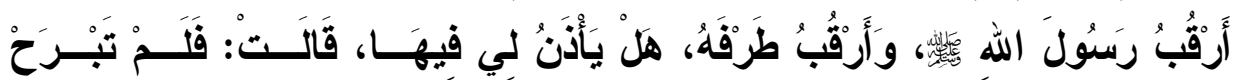

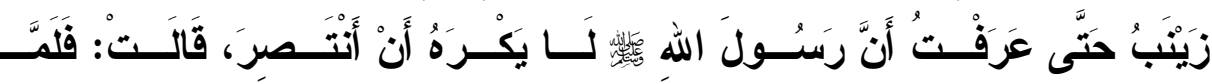

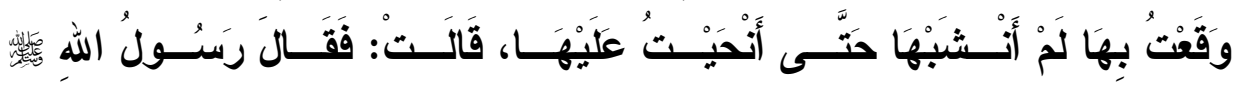

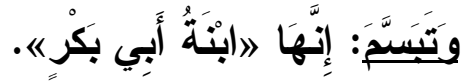

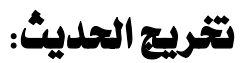

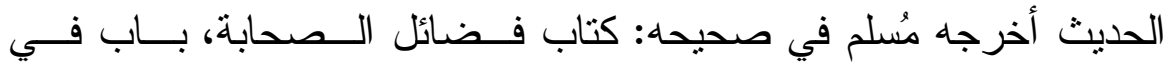

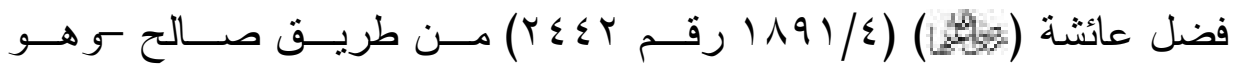

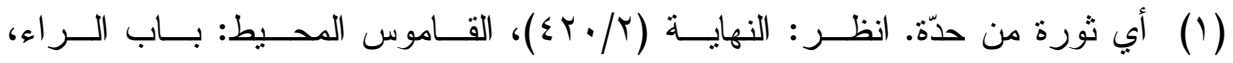

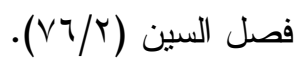


ابن كيسان - عن ابن شهاب عن محمد بن عبــــ الــرحمن بـن الحـــارث بـن هثام عن عائشة.

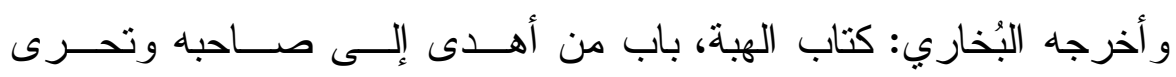

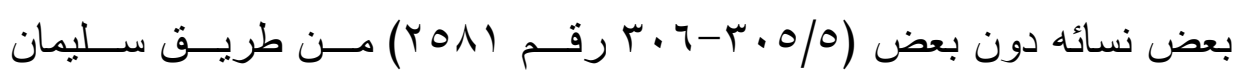
عن هشام بن عروة عن أبيه عن عائشة نحوه، ولم يذكر التبسم.

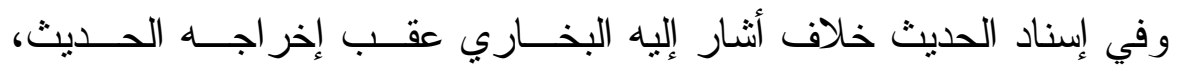

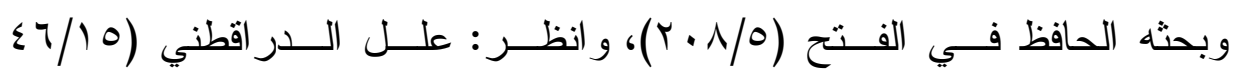

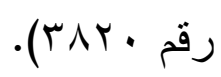

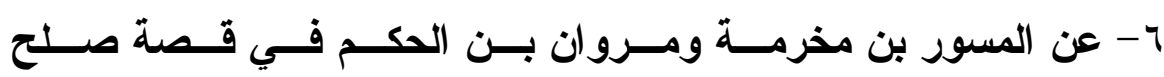

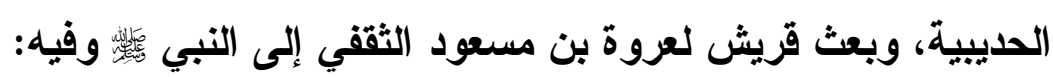

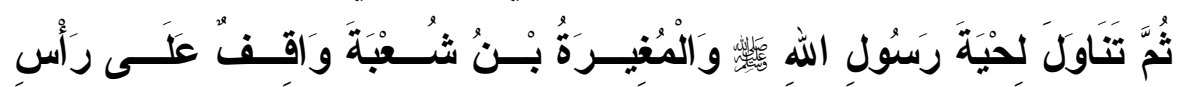
رَسنولِ اللهِ

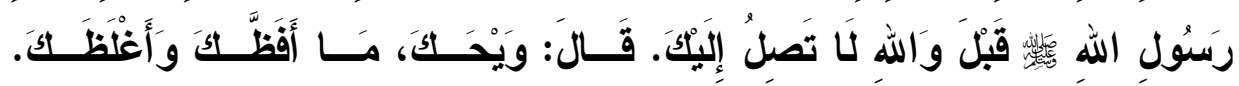

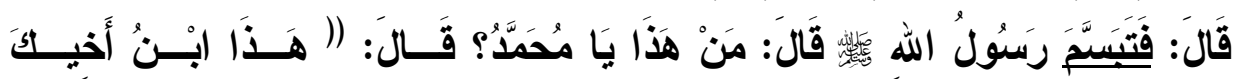

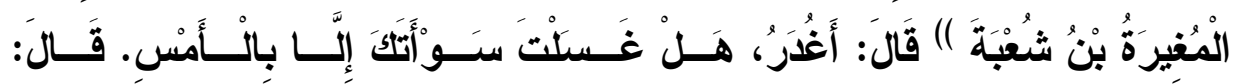

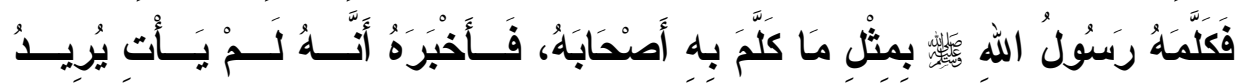
حَرْبًا.... الخخ الحديث.

\section{تخريج الحديث:}

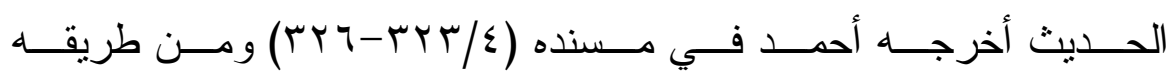

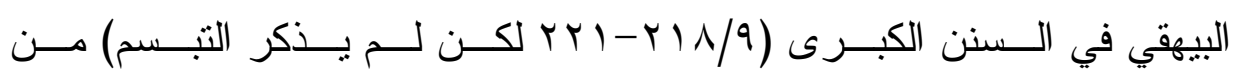
طريق ابن إسحاق عن الزهري عن عروة بـن الزبيـر عـن المسسور بـن مخرمة ومروان بن الحكم الحديث بطوله. 


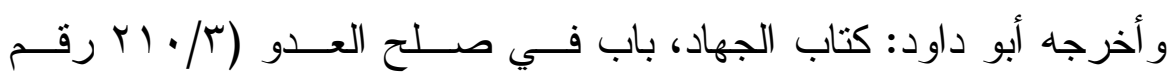

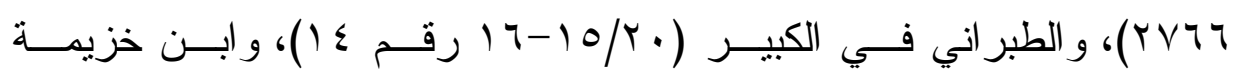

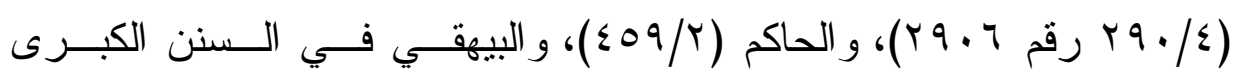
(Y 10/0) من الطريق المشار إليه لكـن مــن غيــر ذكــر موضــع الـشـاهد قال الحاكم: هذا حديث صحيح على شرط مُسلم ولم يخرجاه. وفي سنده ابن إسحاق وهــو محمــد بـن إبـــحاق بـن بـسـار المطلبـي

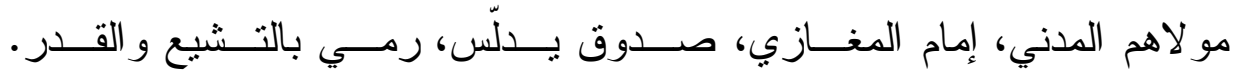

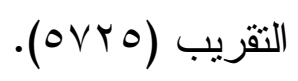

وقد صرح هنا بالتحديث كما ورد في أثتــاء ســياق القـصة فــي مسـسند أحمد، وحديثه لا ينزل عن الحسن، وهو في بــاب الـسبر و المغـــازي الــذي وفي هو إمامه.

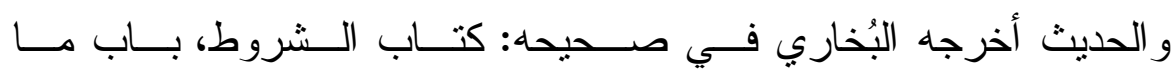

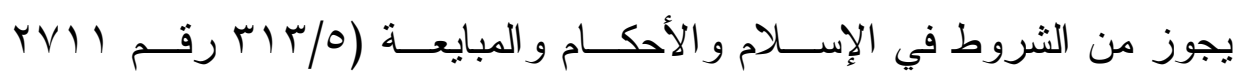

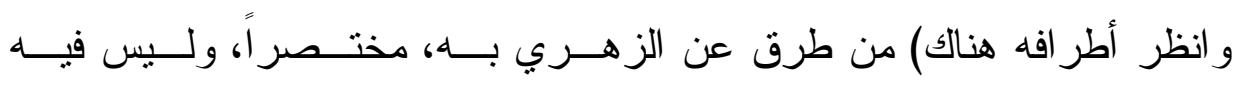
ذكر التبسم.

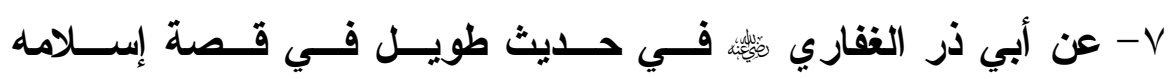
وفيه فقال:

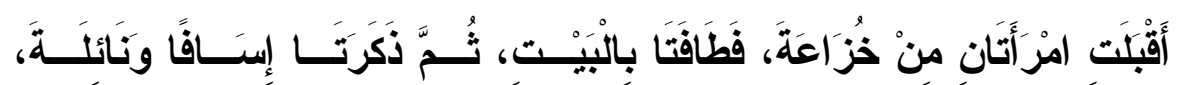

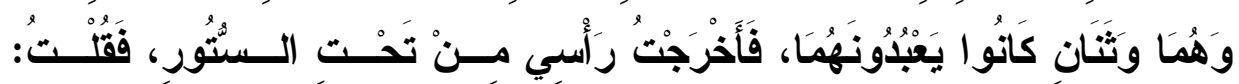

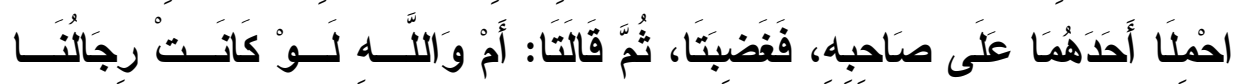

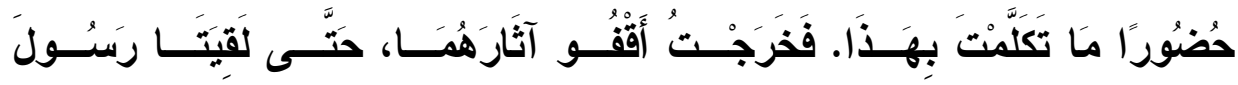




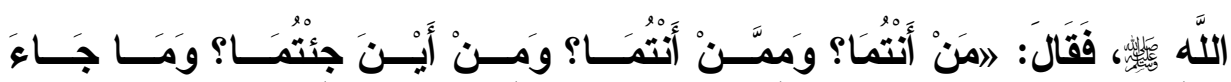

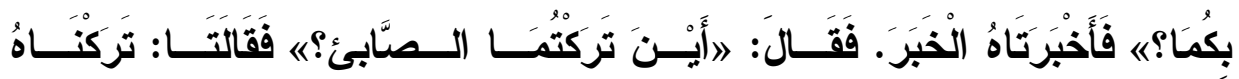

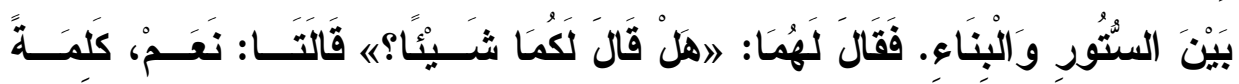

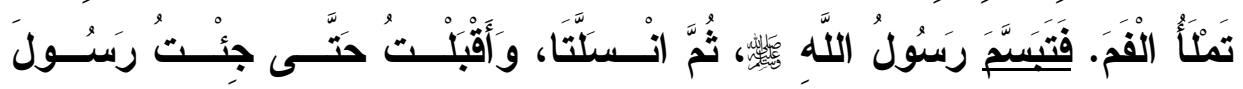

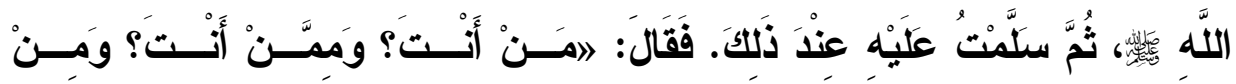

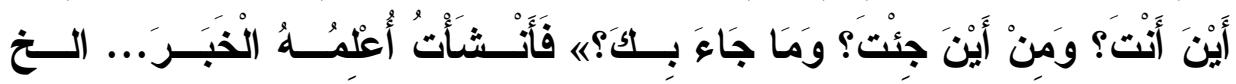
الحديث.

\section{تخريج الحديث:}

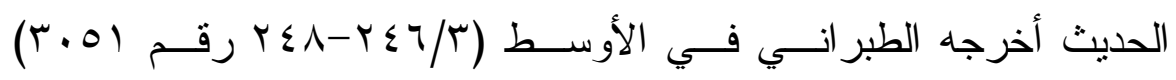

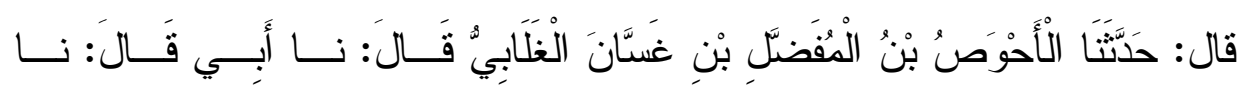

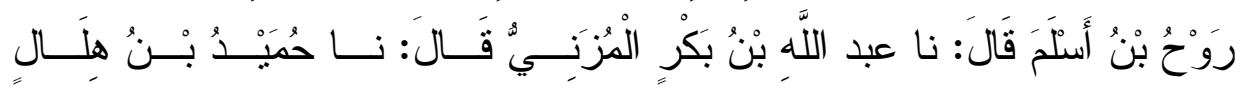

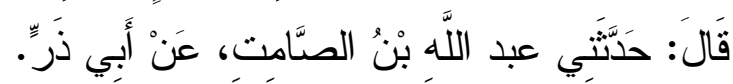

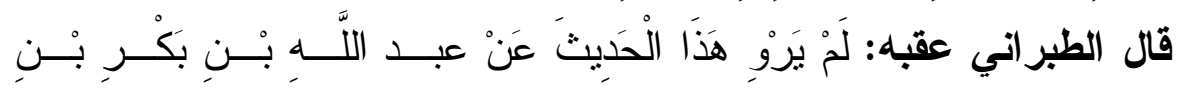

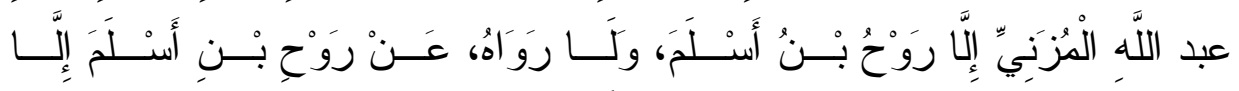

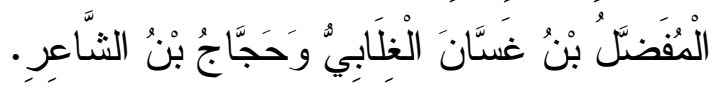

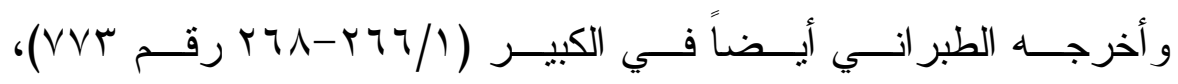

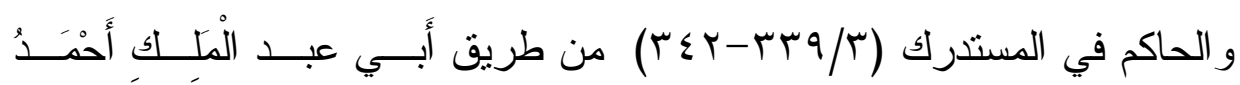

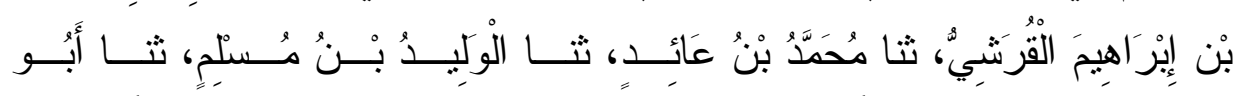

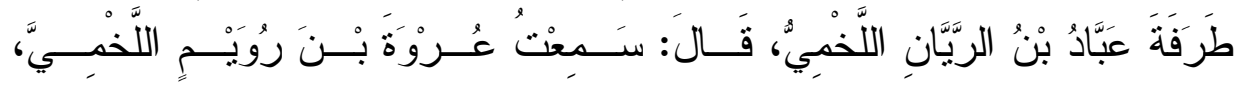

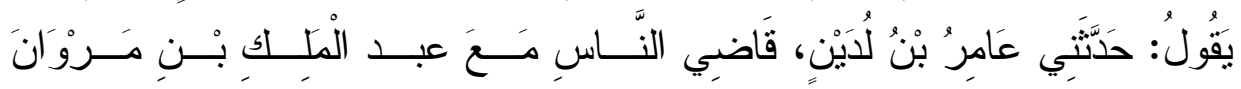

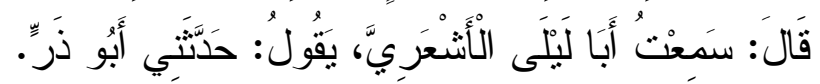
قال الأهبي في تلخيص المستدرك: إسناده صالح. 
و الحديث أخرجه مُسلم في صــحيحه: كتــاب فـــائل الــصحابة، بــاب

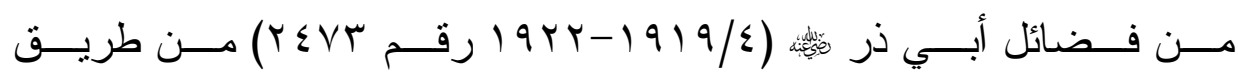

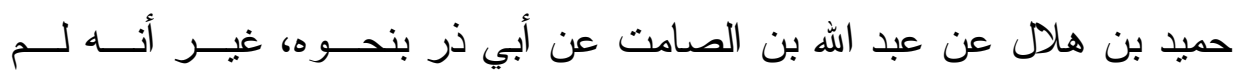

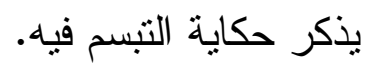

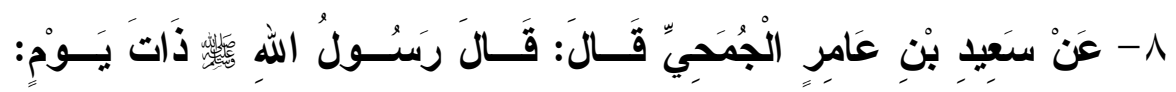

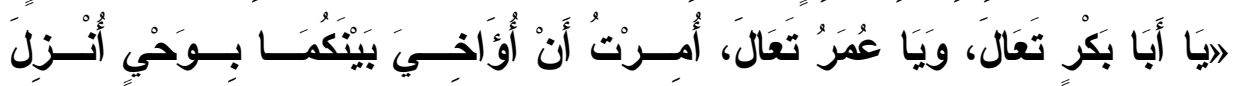

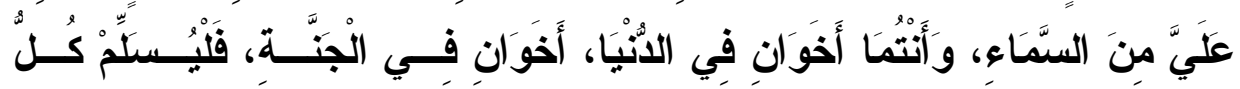

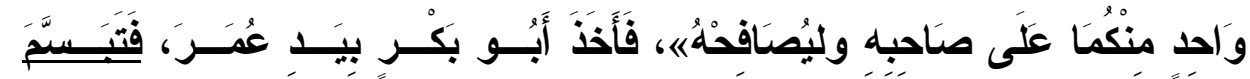

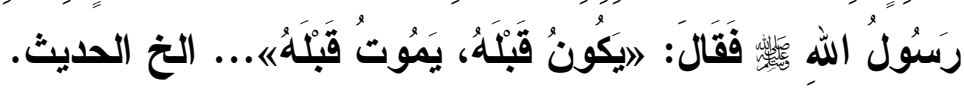

\section{تخريج الحديث:}

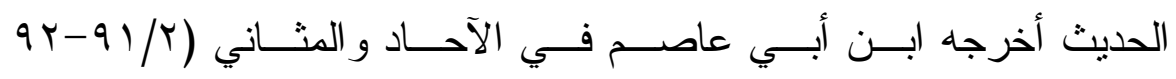

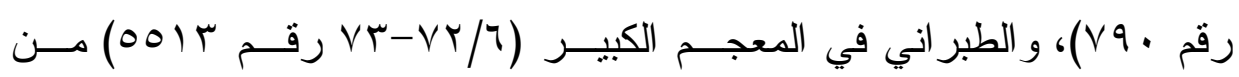

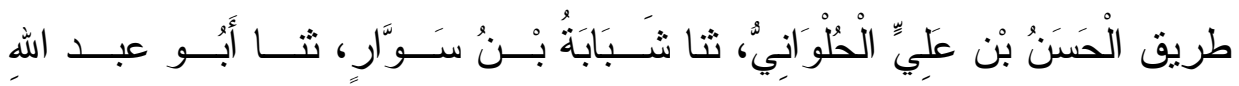

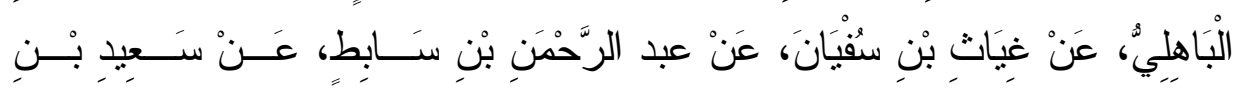
عَامرٍ الْجُمَحِيِّ.

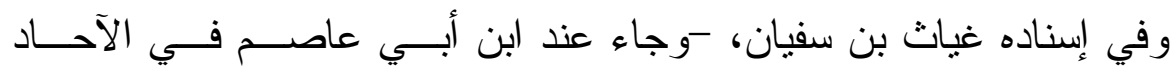
و المثاني: (عتاب)-، و الرواي عنه أبو عبد الله الباهلي، لم أقف عليهما.

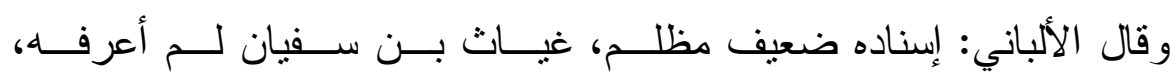

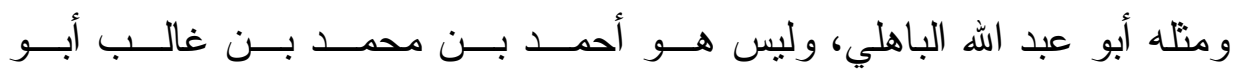

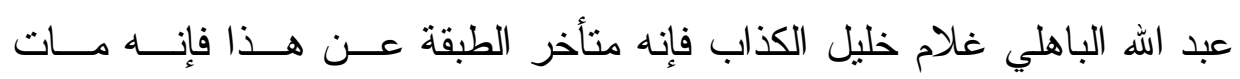

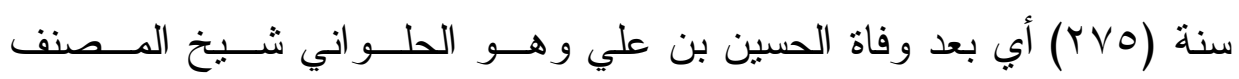
فيه بنحو ثلاثين سنة، فإن الحلو اني مات سنة (r ك ب). 
انظر : ظلال الجنة في تخريج السنة لابن أبي عاصم (T/Y ؟ ه).

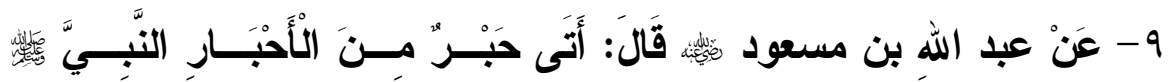

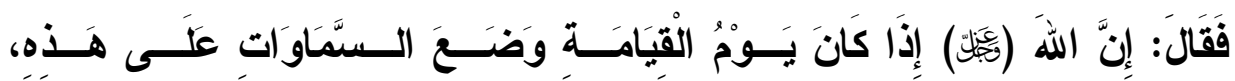

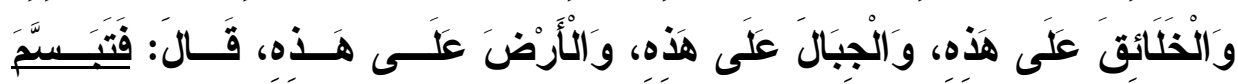
رَستـــــولُ اللهد

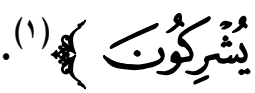

\section{تخريج الحديث:}

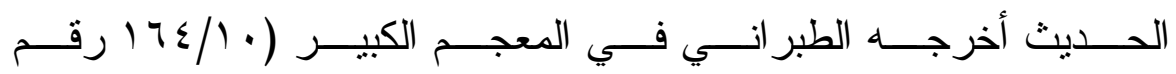

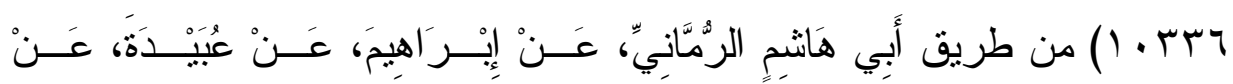
عبد الله.

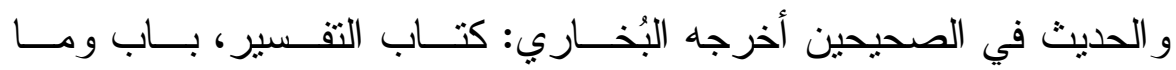

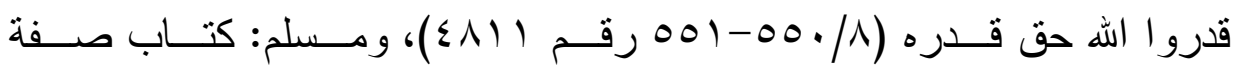

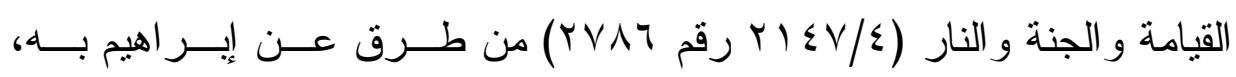

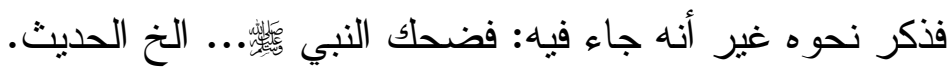
•

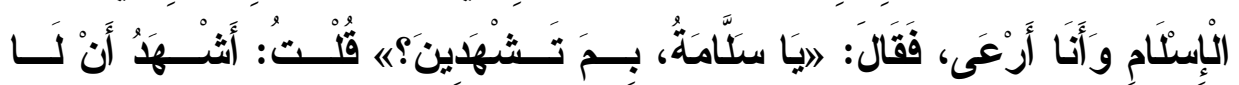

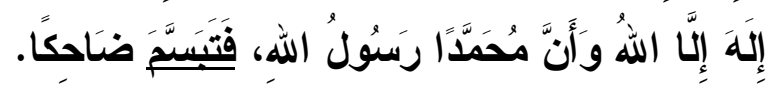

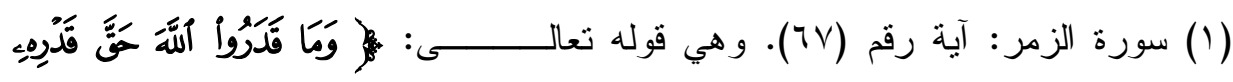

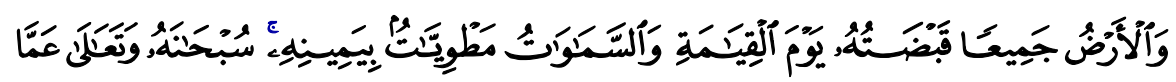

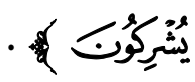




\section{تثريج الحديث:}

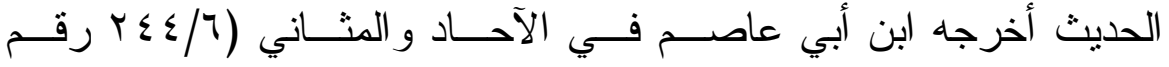

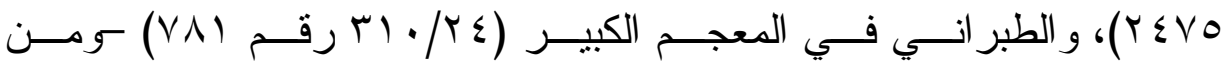

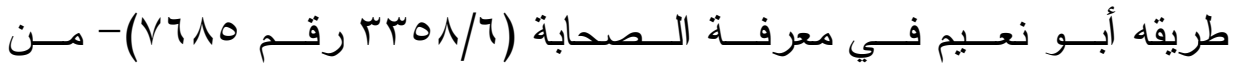

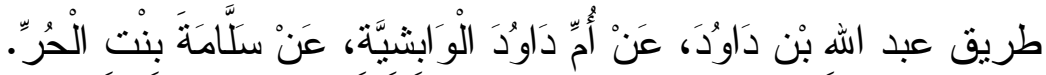

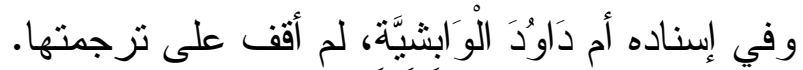

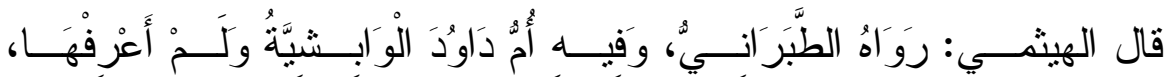

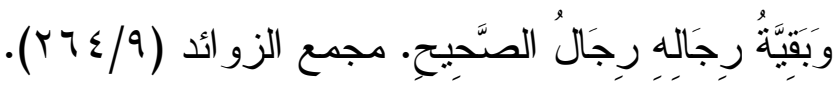

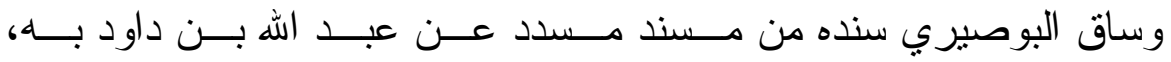

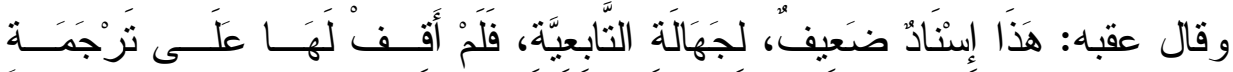

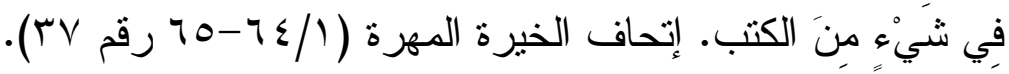

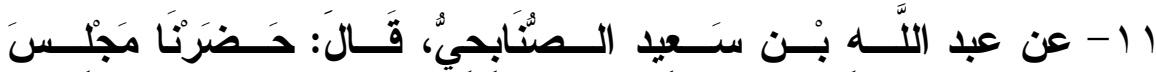

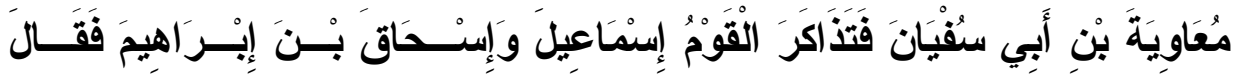

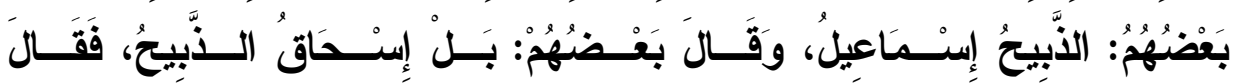

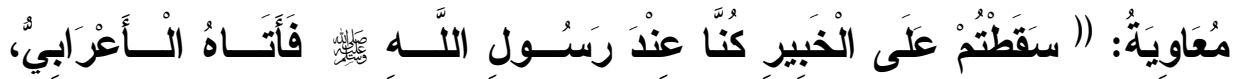

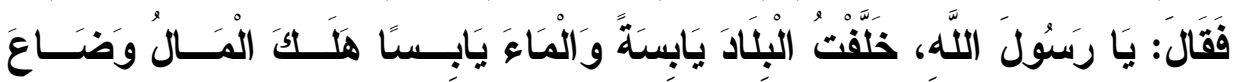

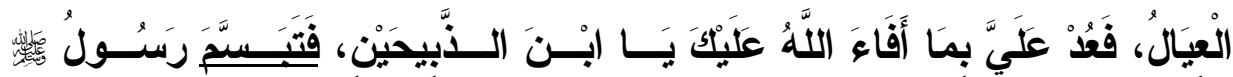

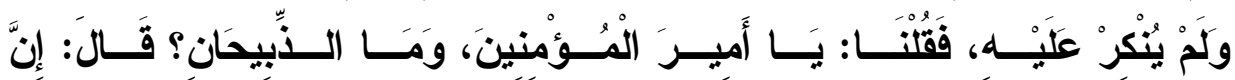

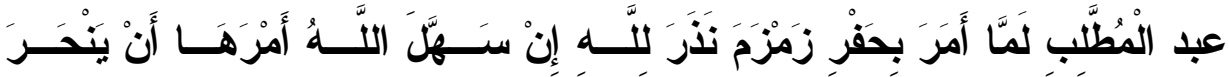

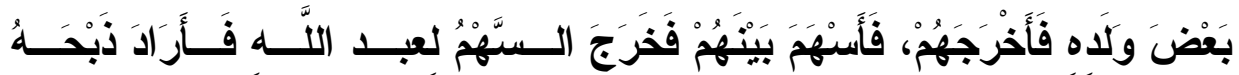

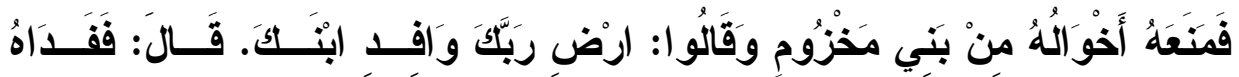

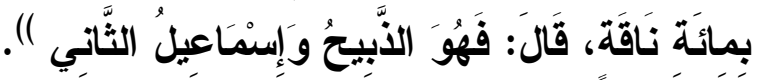




\section{تخريج الحديث:}

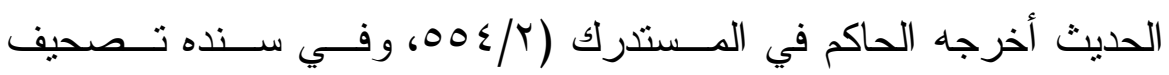

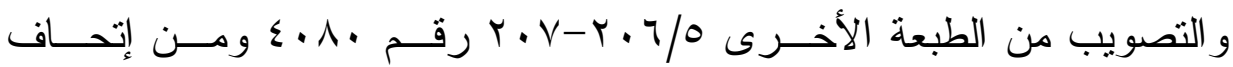

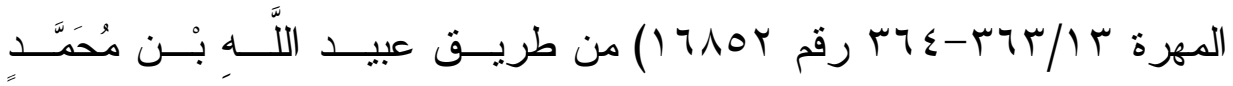

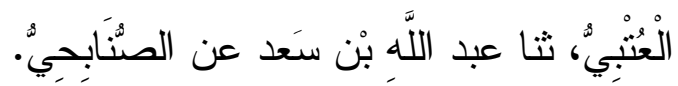
قال الذهبي في تلخيصه: إسناده و اه.

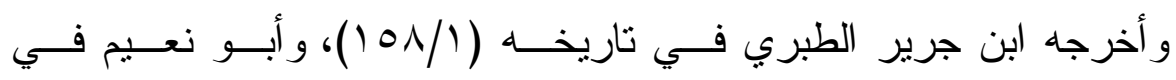

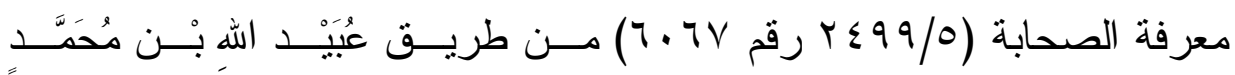

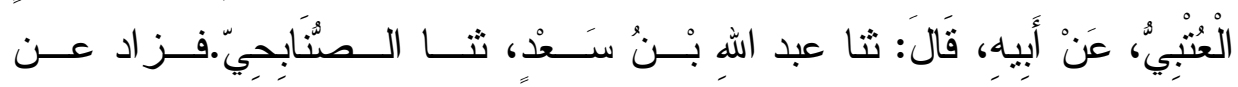

قال ابن كثيــر : هــذا حـديث غريــب جــدا. تفـسير القــرآن العظــيم $\cdot(r \circ / \mathrm{V})$

وقال السيوطي: هذا حديث غريب، وفي إســناده مسـن لا يعـرف حالــه.

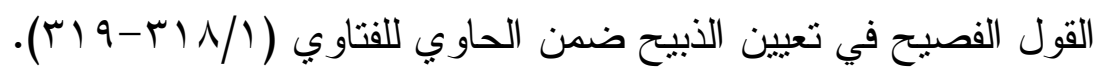

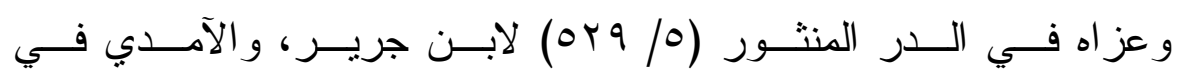
مغازيه، و الخلعي في فو ائده و لابن مردويه وقال: بسند ضعيف.

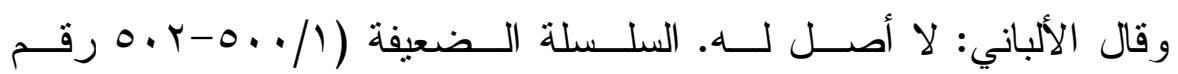

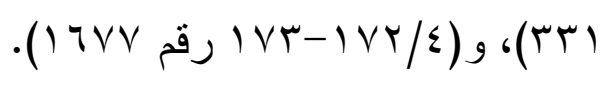

rا

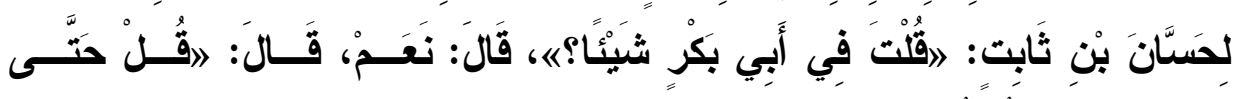

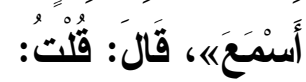

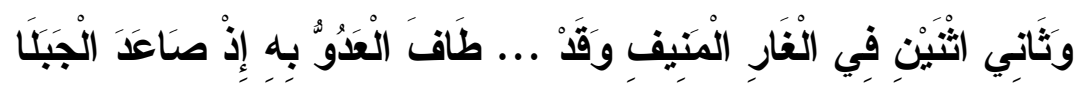




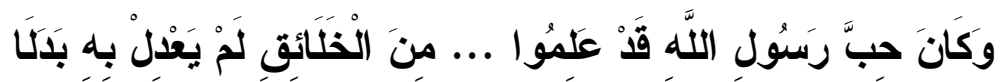

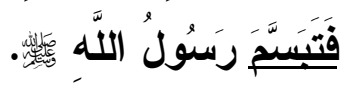

\section{تخريج الحديث:}

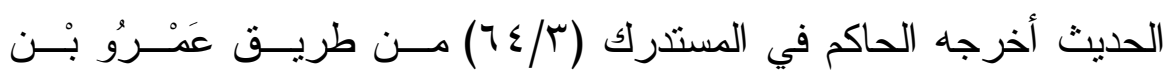

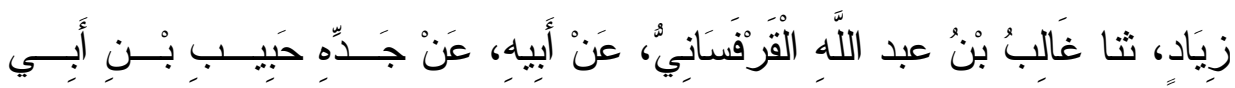

حَبِيب.

وتعقبــه الــذهبي فــي تلخيــصه للمــستدرك فقــال: وعمــرو بــضع

الحديث.يعني عمرو بن زياد.

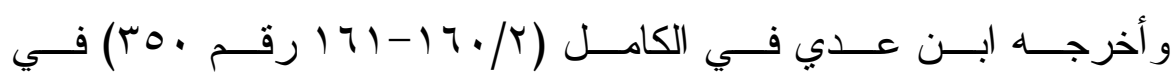

ترجمة الجر اح بن منهال أبو العطوف الحرانـي، مــن طريــق محمـــــــن بـن

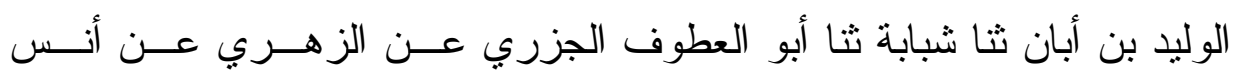
بن مالك.

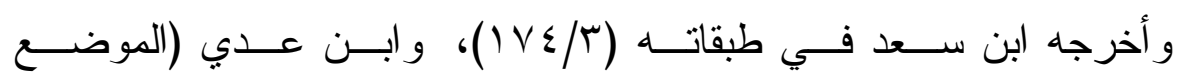

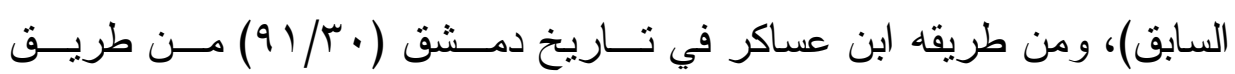
شبابة ثنا أبو العطوف الجزري عن الزهري مرسهاً.

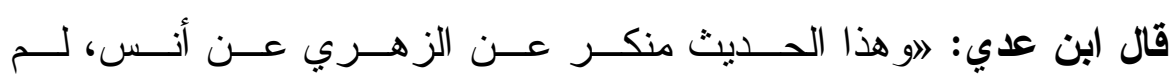

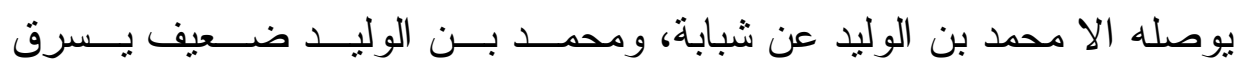

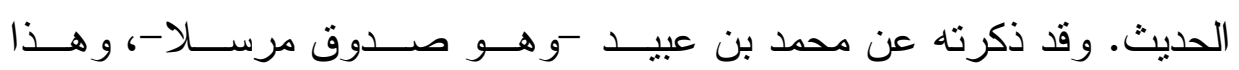

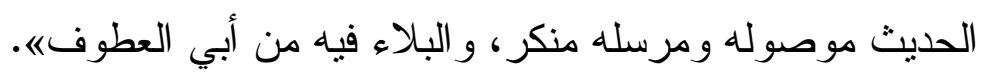

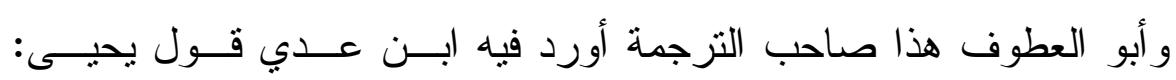

ليس حديثه بشيء، وقال مرة: ضعيف، وقـال علـي بــن المــديني: ضــــيف لا يكتب حديثه، وقال: منكر الحديث، وقال النسائي: منروك الحديث. 


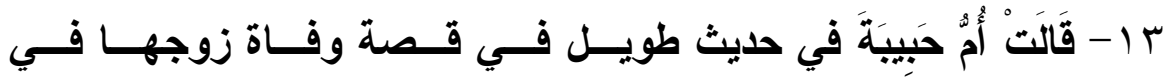

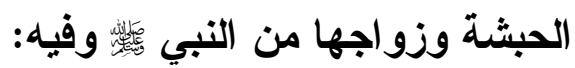

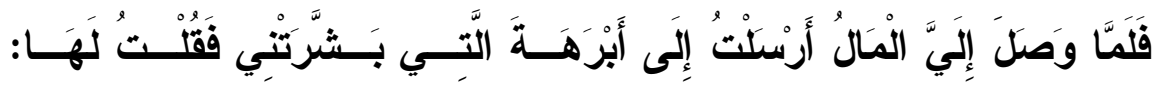

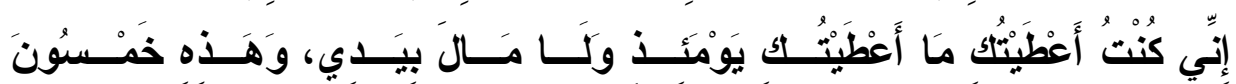

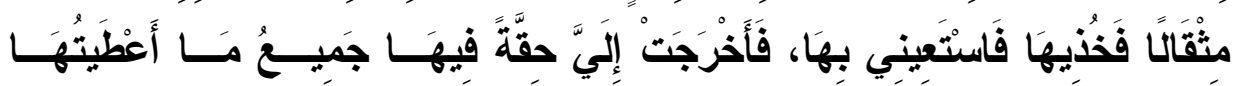

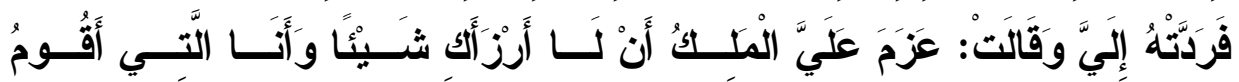

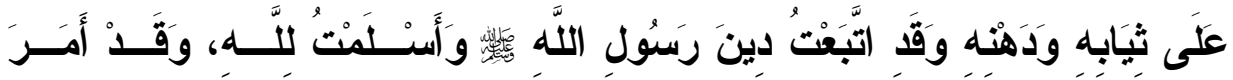

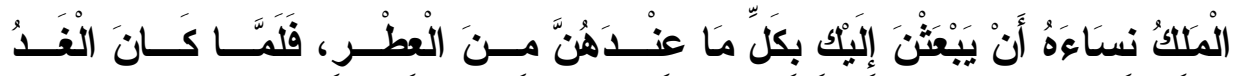

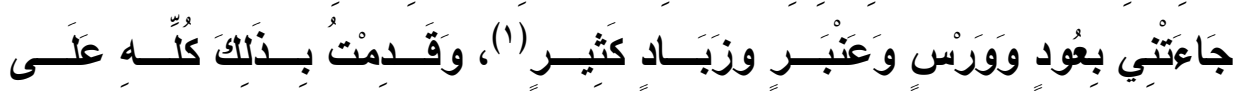

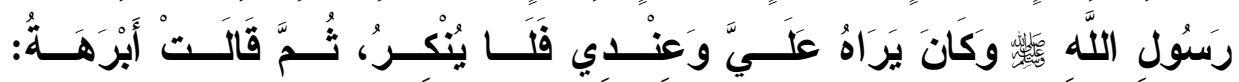

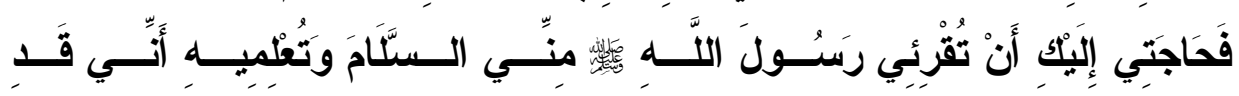

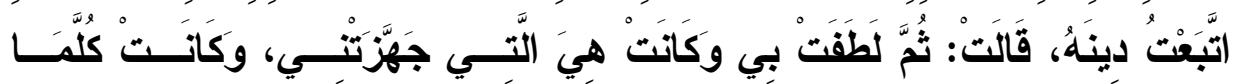

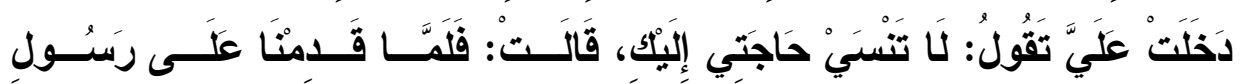

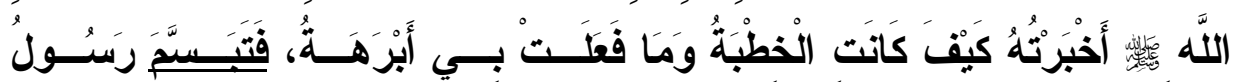
اللَّهَهِ

$$
\text { وَبرَكَاتُهُهُه. }
$$

\section{تخريج الحديث:}

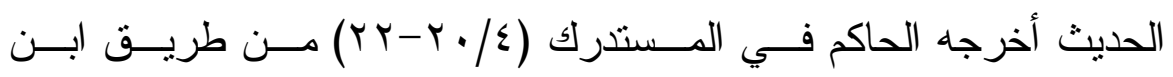

عمر حدثا عبد الله بن عمرو بن زهيـر عـن إســماعيل بـن عمــرو بـن

$$
\text { سعيد بن العاص قالت أم حبيبة:... الحديث. }
$$

الزّباد: نوع من الطيب. انظـــر : القــاموس المحــبط: بــاب الــــال، فـــل الــزاي 


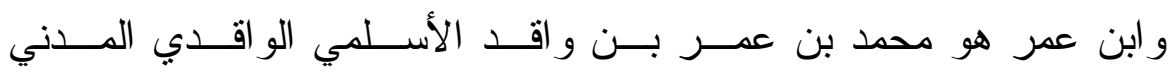

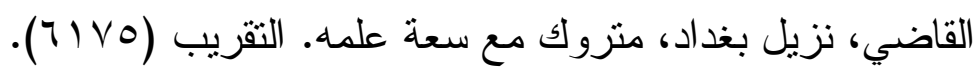
فالإسناد ضعيف جدا.

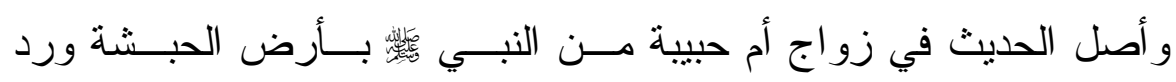
من غير هذا الطريق.

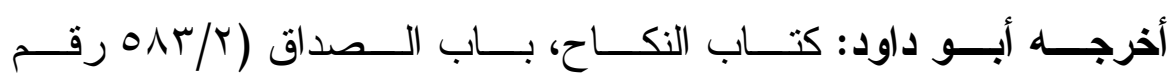

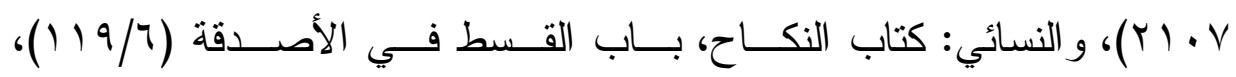

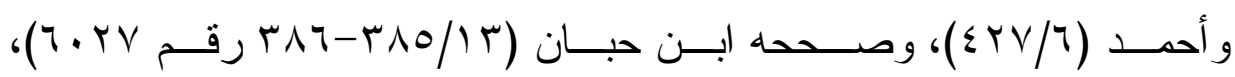

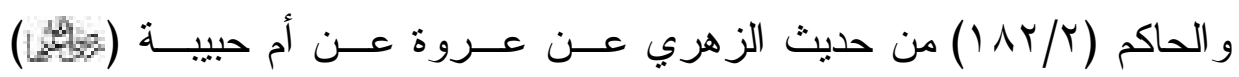

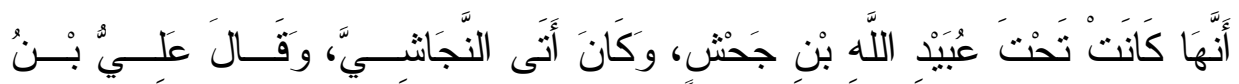

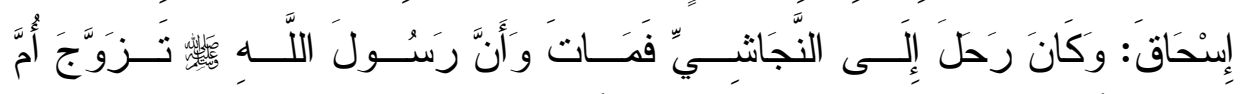

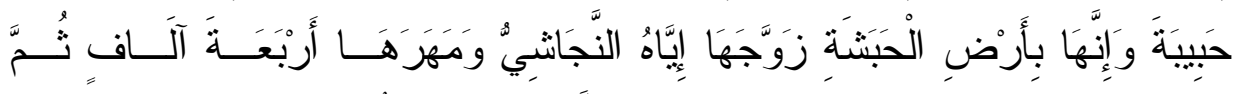

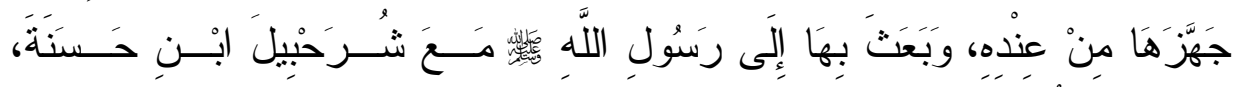

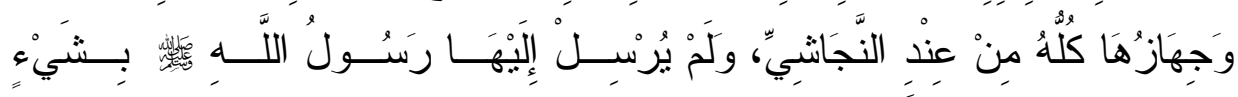

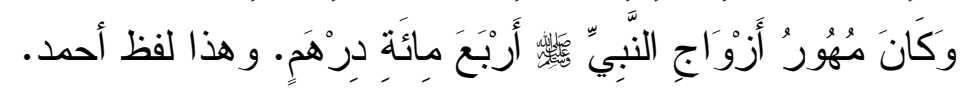
قال الحاكم: هذا حديث صحيح على شرط الثيخين ولم يخرجاه.

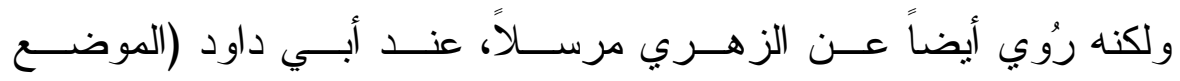

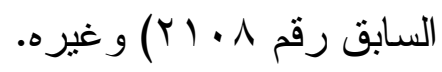

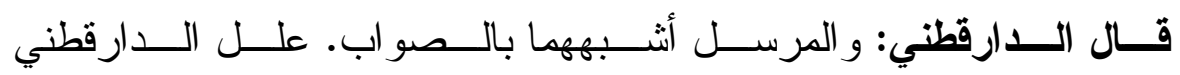
$(r \wedge) / 10)$ 


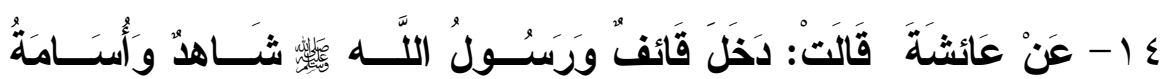

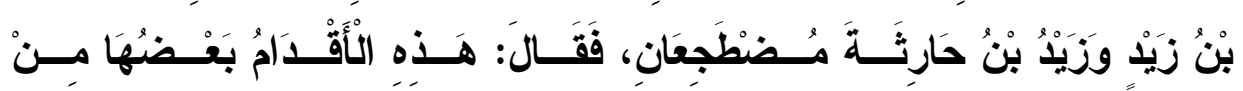

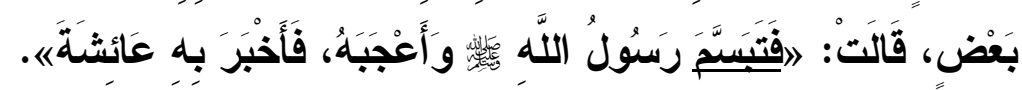

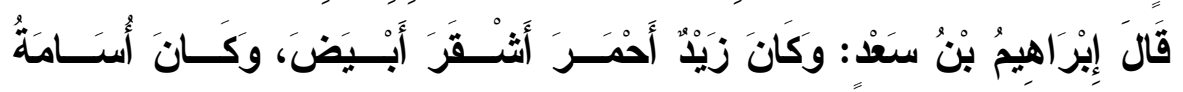

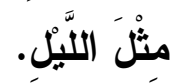

\section{تخريج الحديث:}

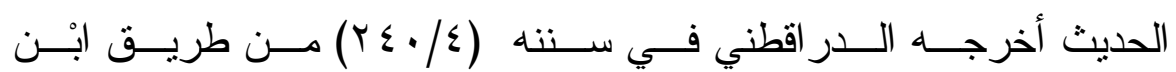

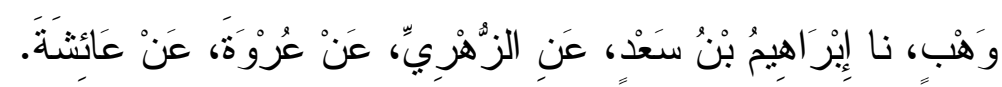

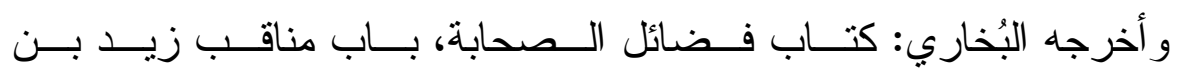

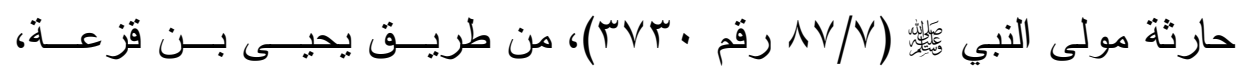

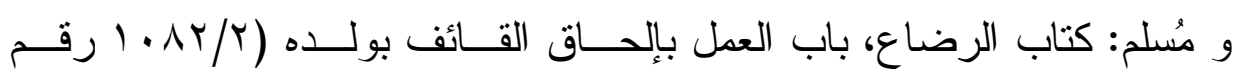

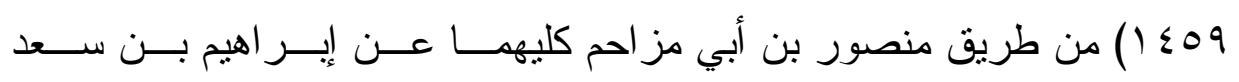

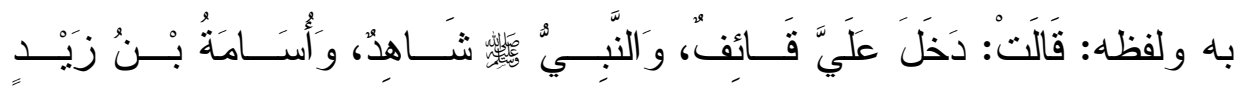

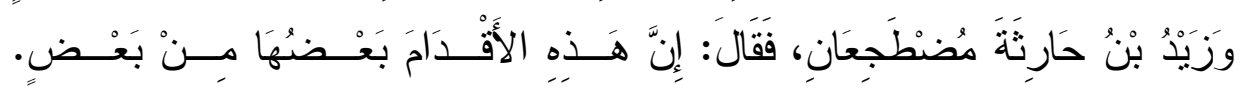

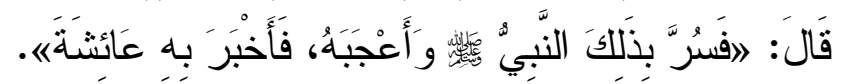
وأخرجاه أيضا من طرق أخرى عن الزهري بنحوه. 


\section{المبحث الثاني}

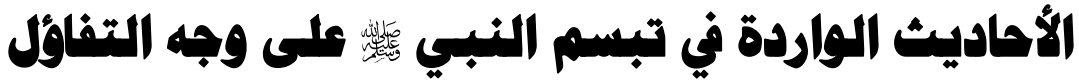

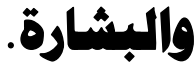

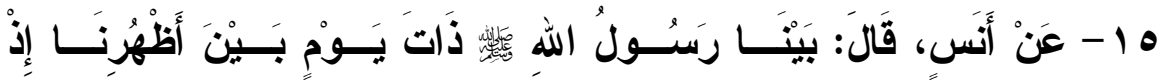

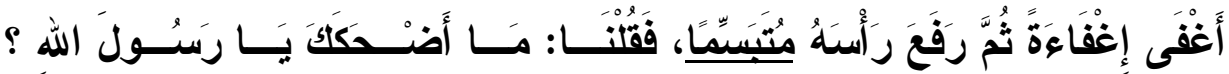

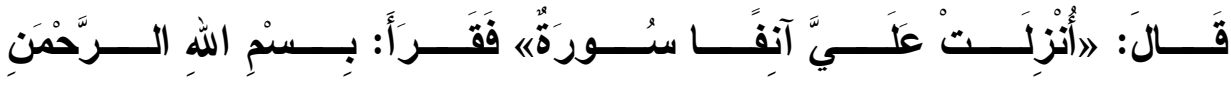

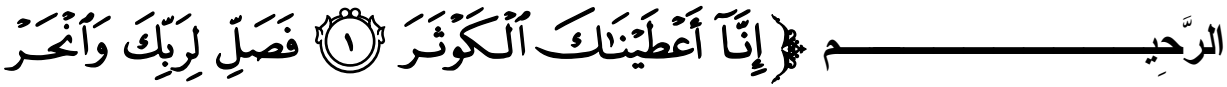

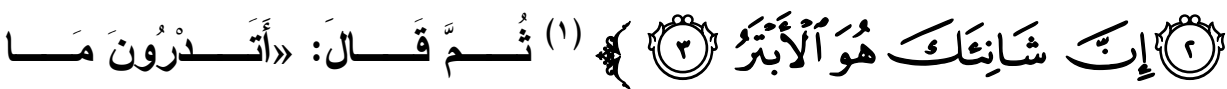

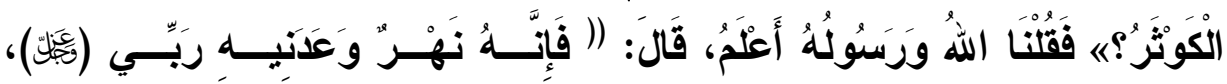

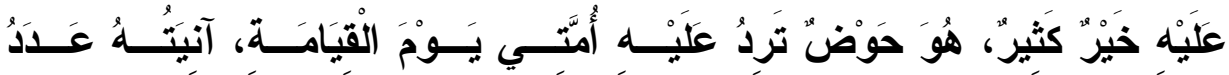

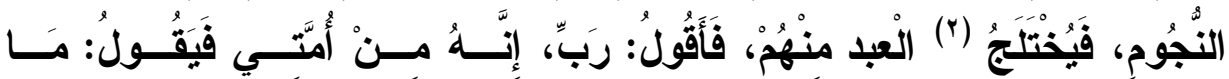

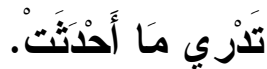

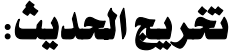

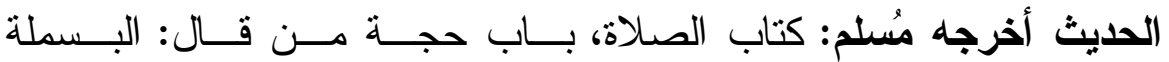

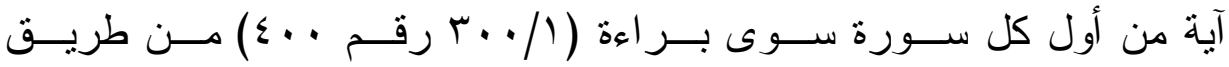

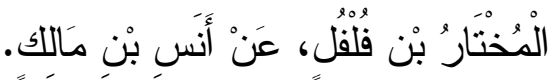

$$
\text { سورة الكوثر : آية رقم (1-ب). }
$$

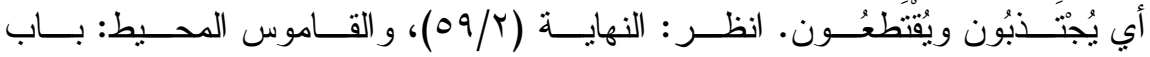

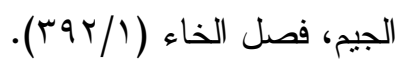




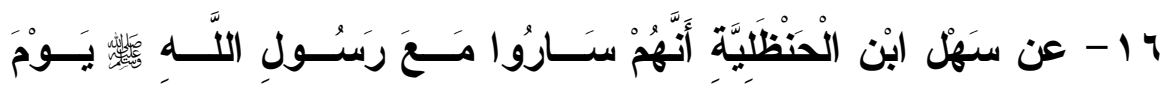

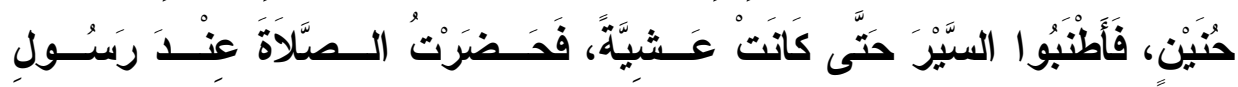
اللَّهَه

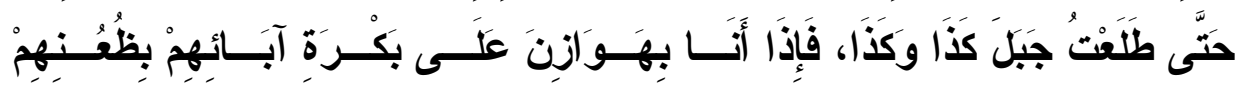

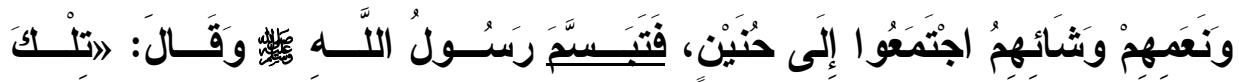

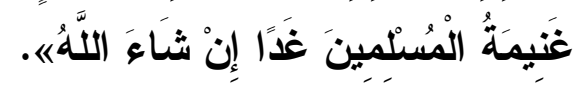

\section{تخريج الحديث:}

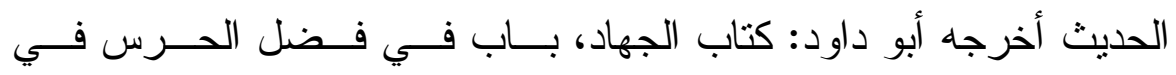

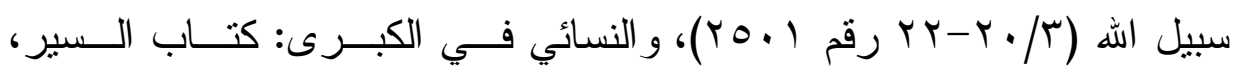

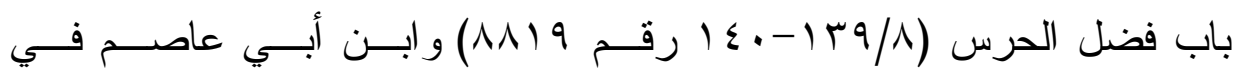

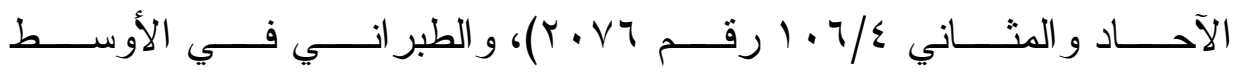

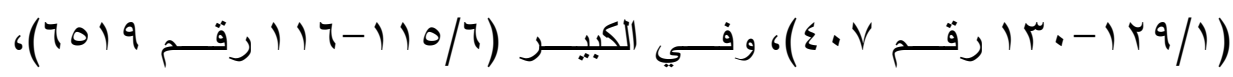

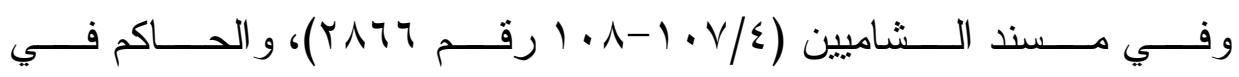

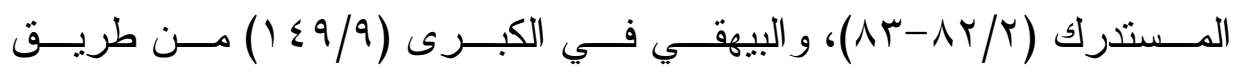

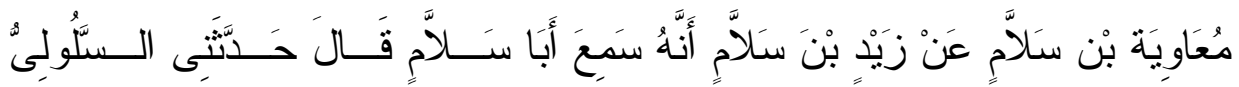

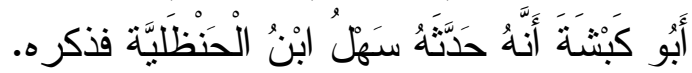

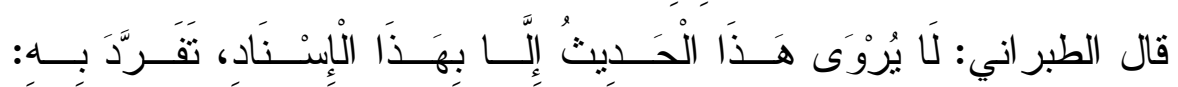

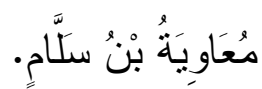

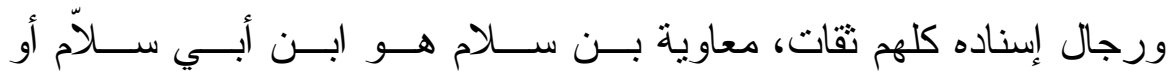

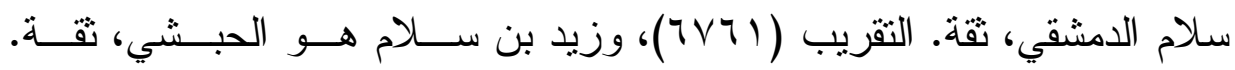




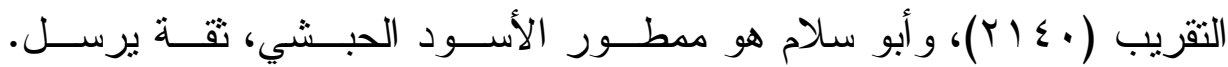

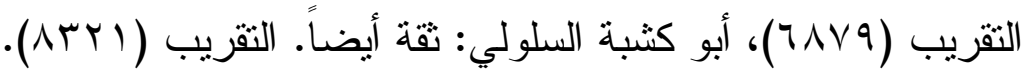

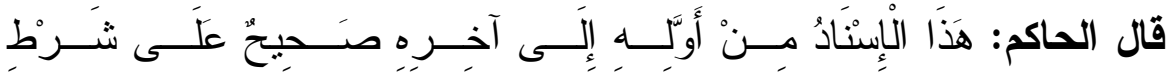

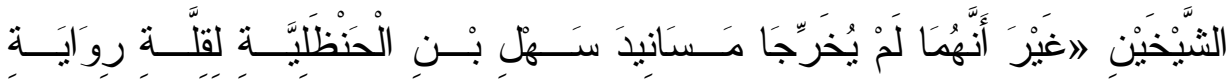

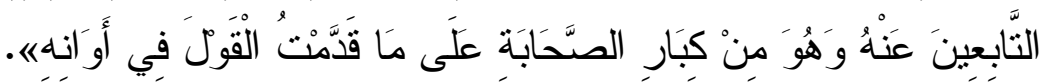

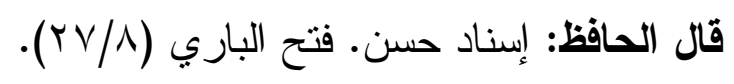

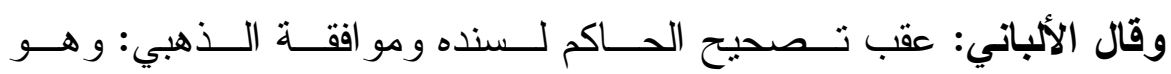
كما قالا. السلسلة الصحيحة (I الابل:

IV

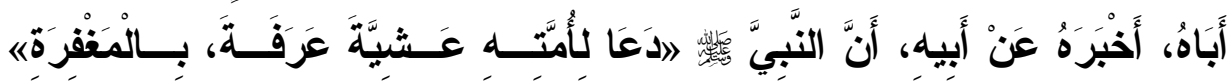

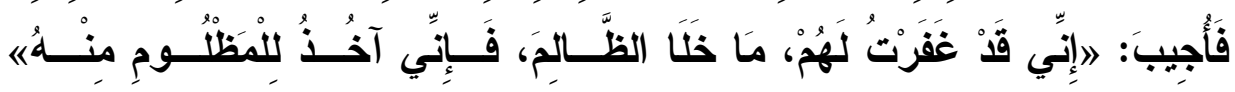

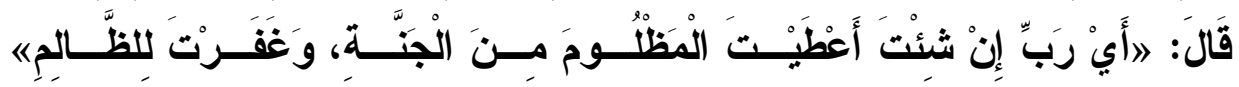

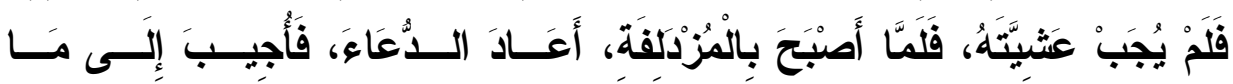

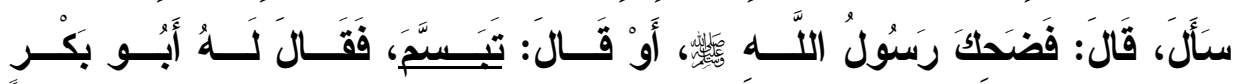

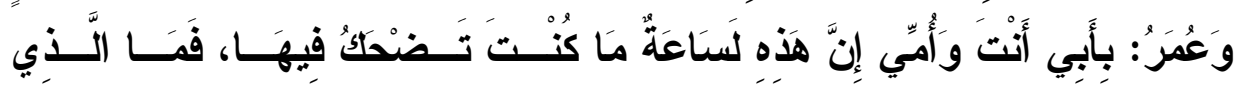

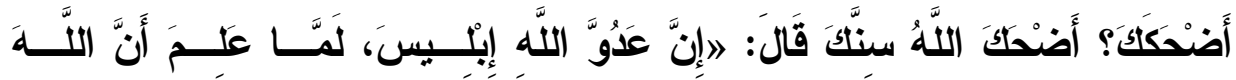

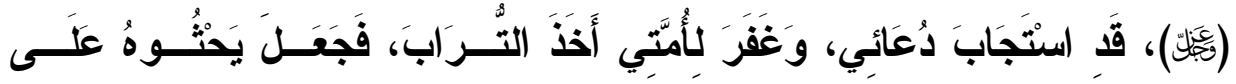

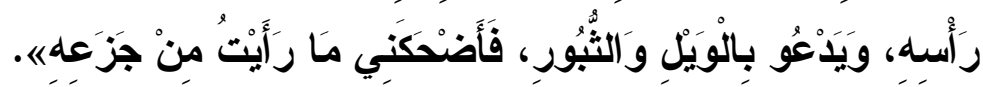

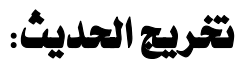

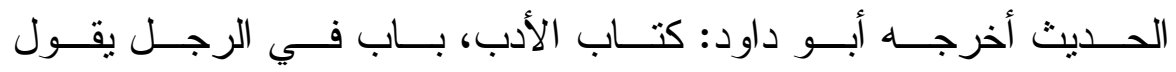

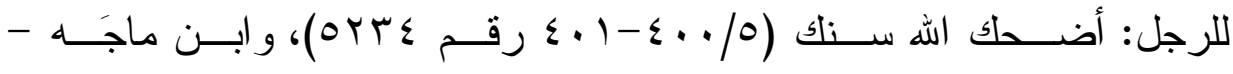

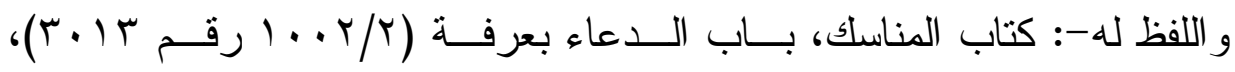




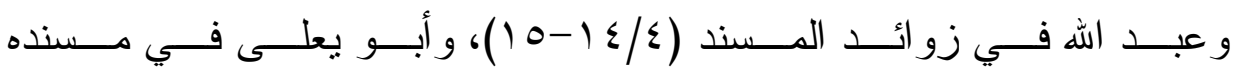

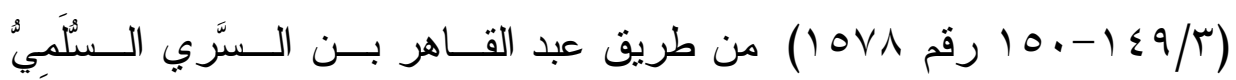

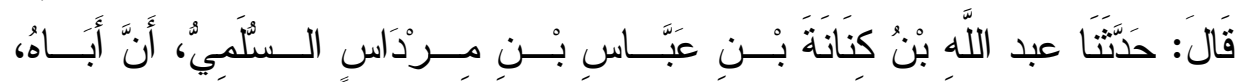

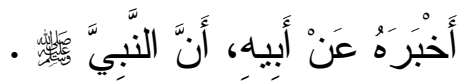

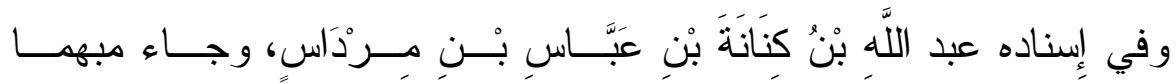

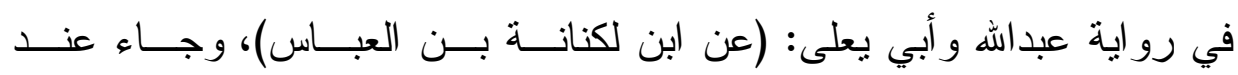

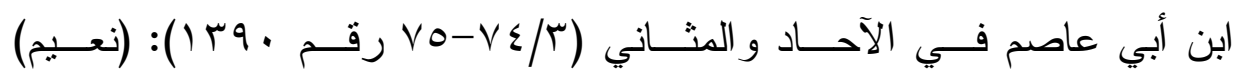
بدل (عبد الله).

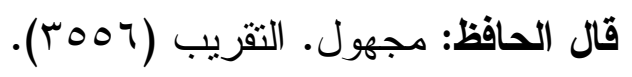

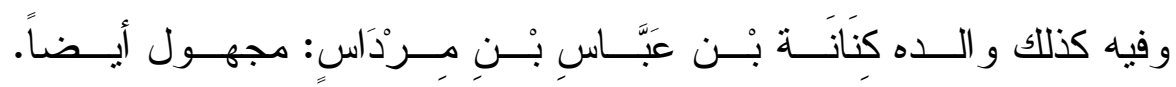

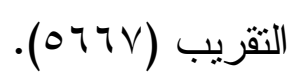

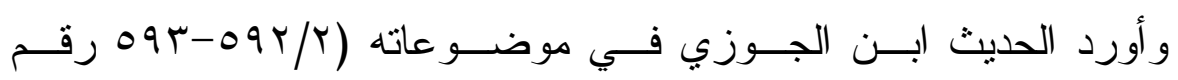

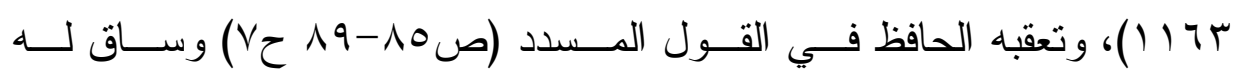
من الثو اهد ما يدل على أن للحديث أصلا.

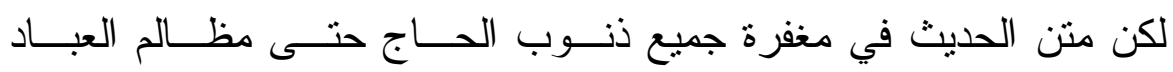

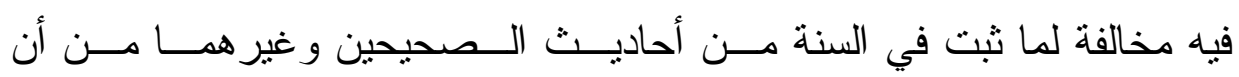

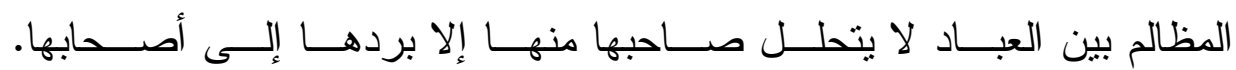

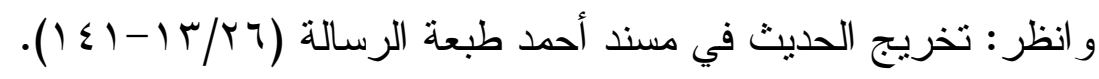

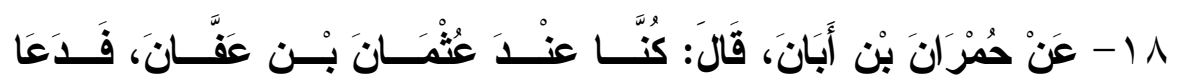

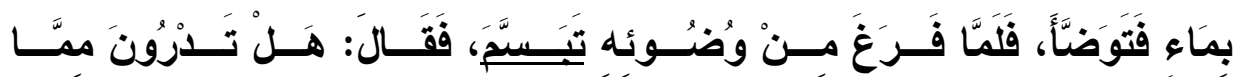

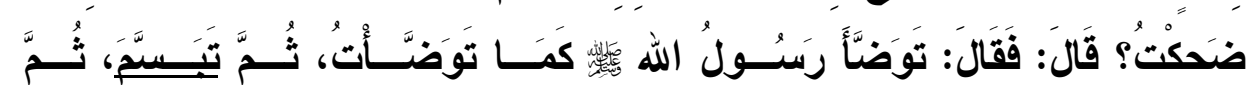

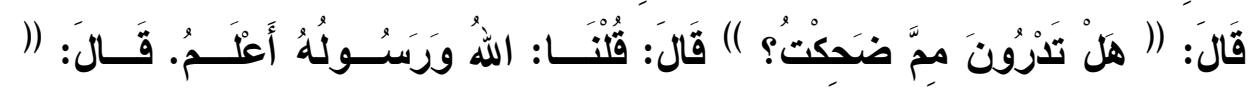




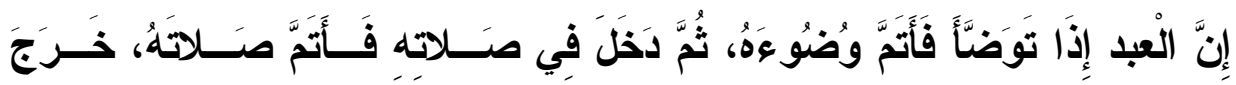

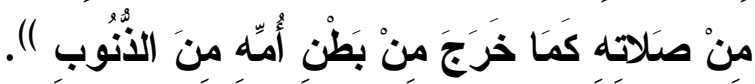

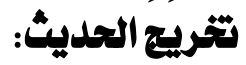

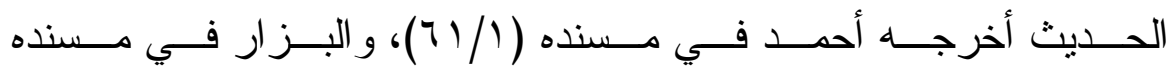

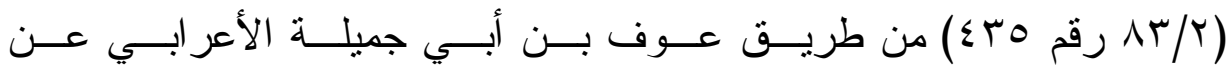
معبد الجهني عن حمران.

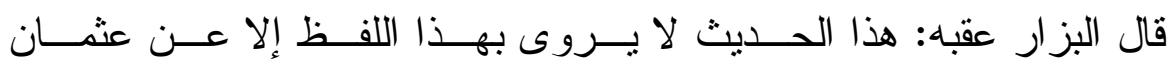
بهذا الإسناد.

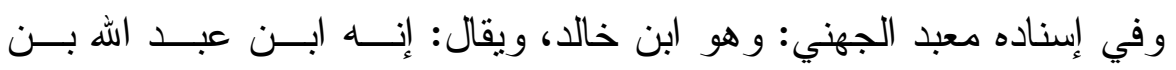

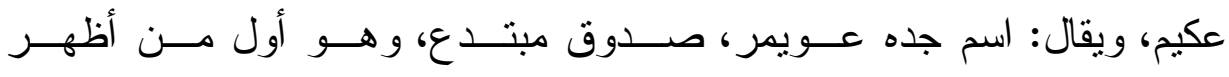
القدر بالبصرة. التقريب (TVVV)

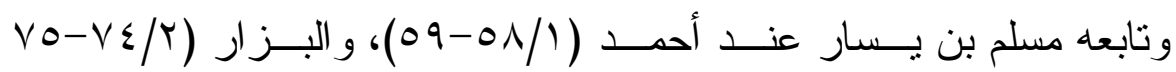

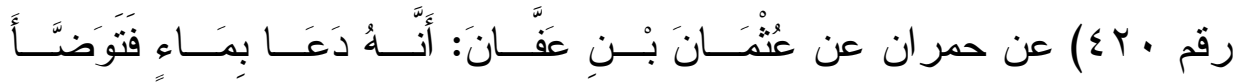

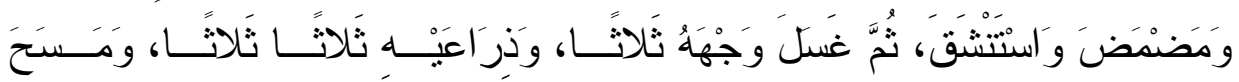

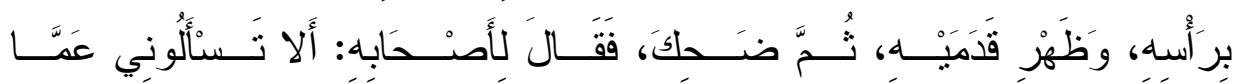

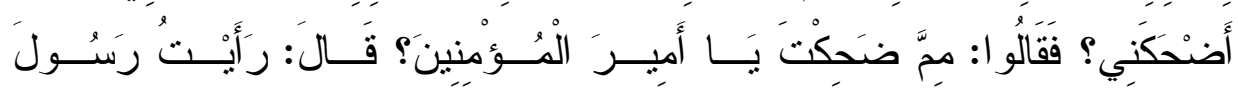

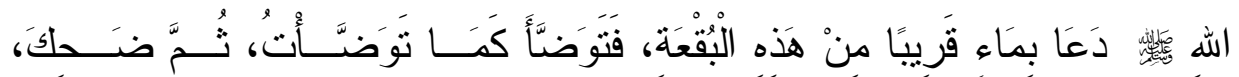

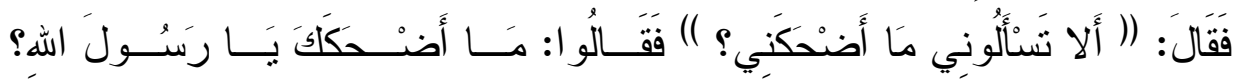

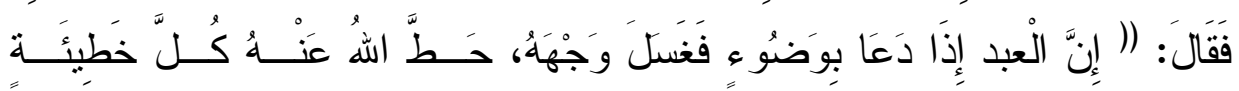

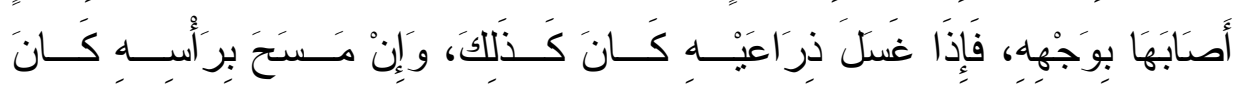

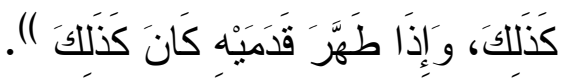




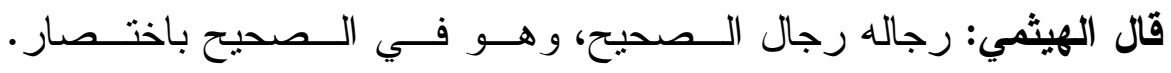

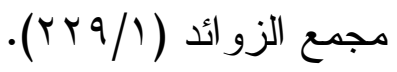

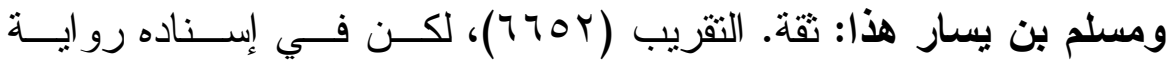

قتادة عنه، وهو لم يسمع منه كما قال: يحيــى بــن معـين. المر اســيل لابــن

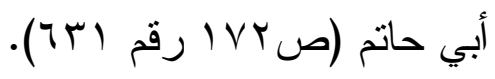

وله علــة أخــرى مرجوحسـة أثنــار إليهـــا الــدارقطني. انظـــر : علــل

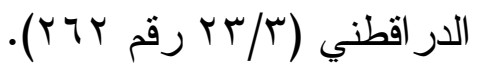

وحديث عثمان في الوضوء ثابــت فــي الــصحيحين مــن طــرق عــن

حمر ان عن عثمان بألفاظ مختلفة، وليس فيها ذكر التبسم.

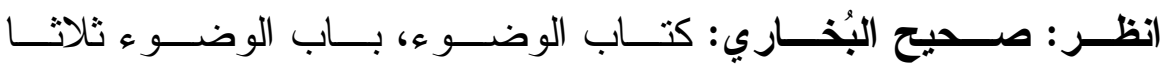

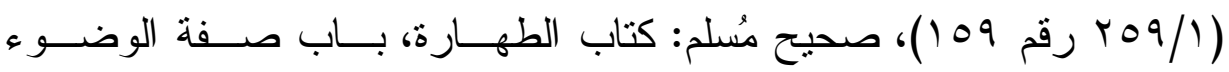

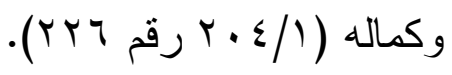

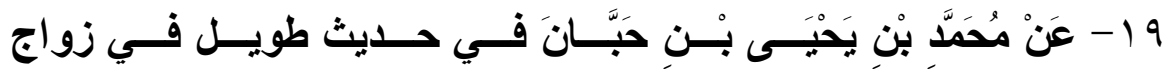

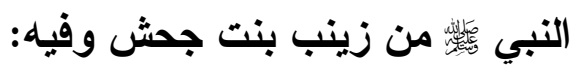

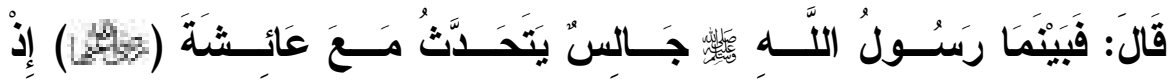

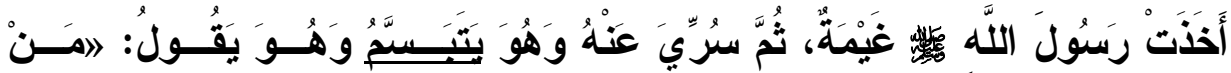

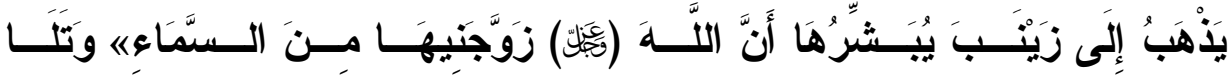

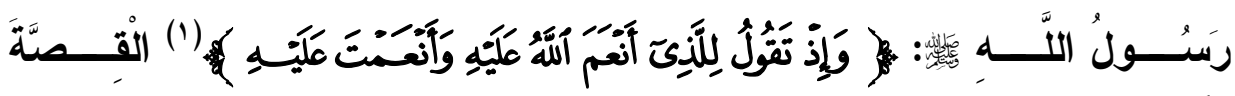

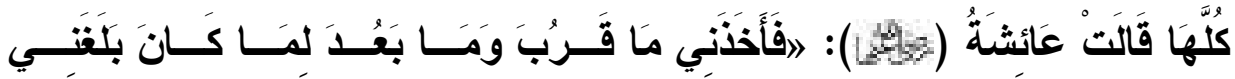

$$
\text { (1) (1) سورة الأحز اب: آية رقم (YV). }
$$




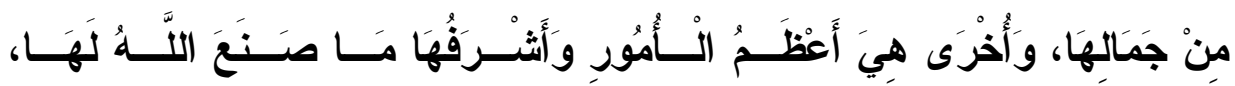

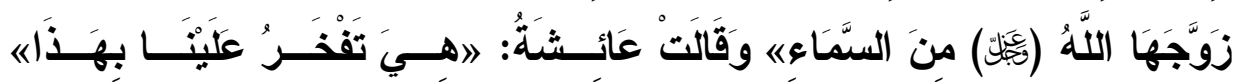

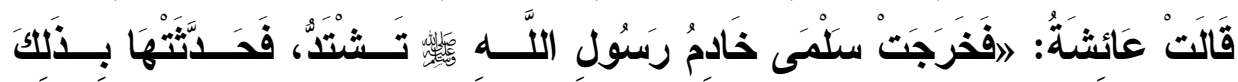

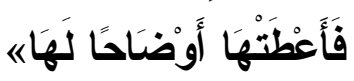

\section{تخريج الحديث:}

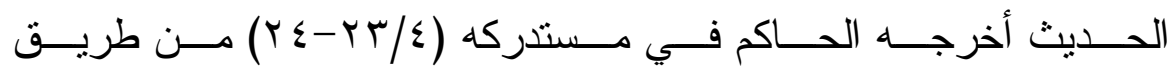

الو اقدي عن عبد الله بن عامر السلمي عن محمد بن يحيى بن حبان به.

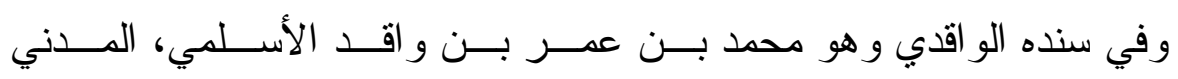
القاضي، متروك مع سعة علمه. التقريب (T) V0).

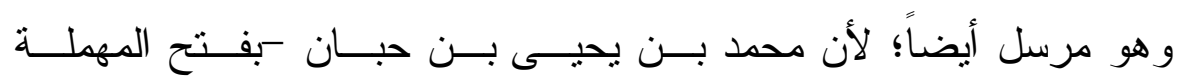

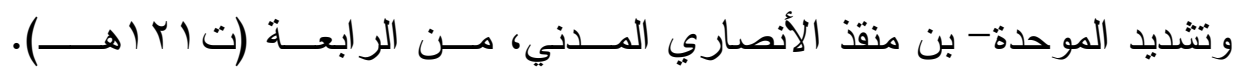

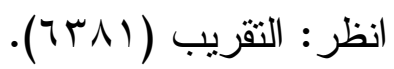

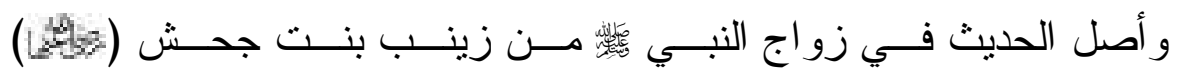

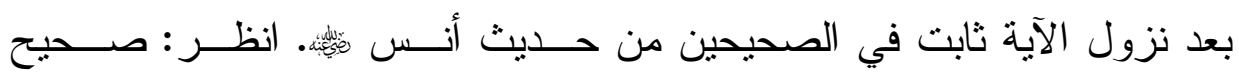

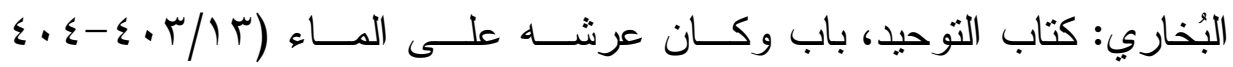

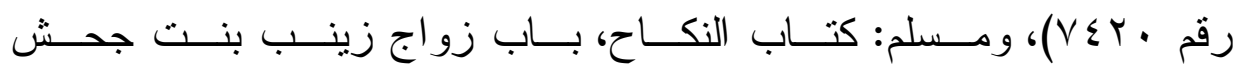

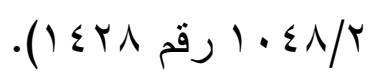

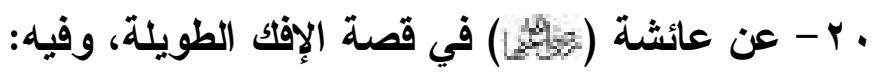

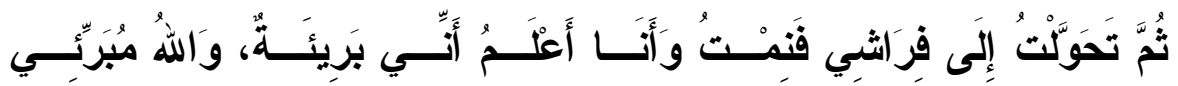

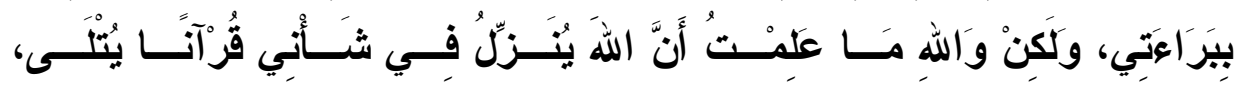

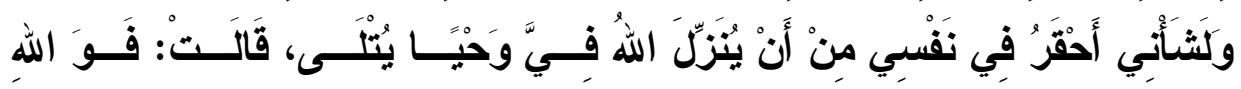




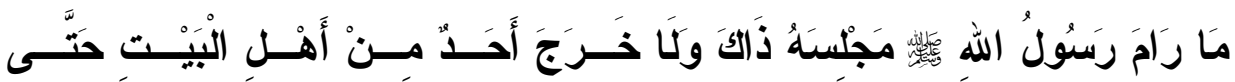

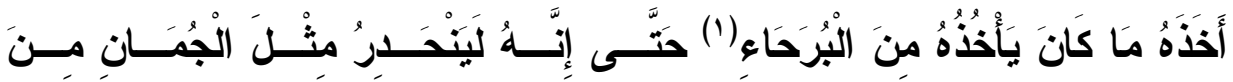

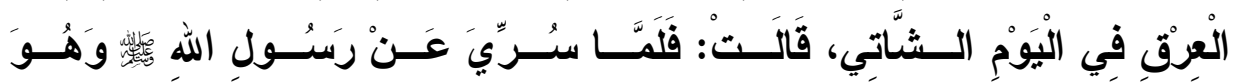

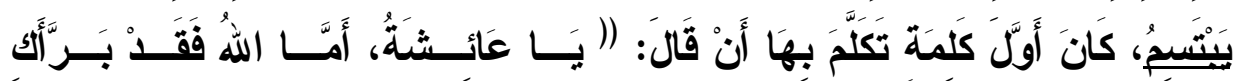

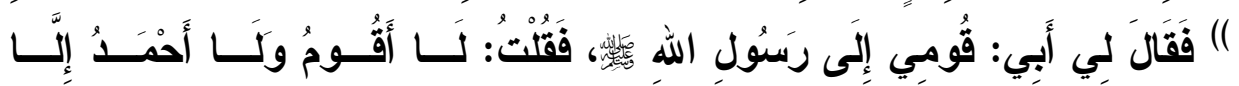
اللهَ تَعَالَى ... التخ الحديث.

\section{تخريج الحديث:}

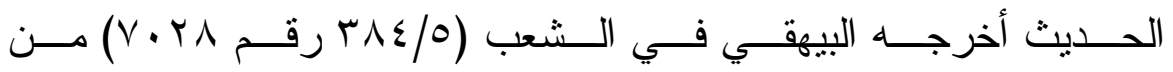

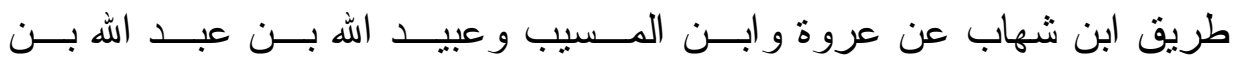
عنبة بن مسعود و علقمة بن وقاص عن عائشة بنحوه.

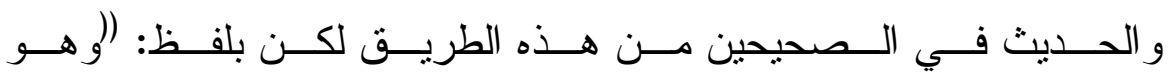

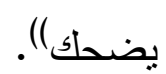

انظر : صحيح البُخاري: كتاب الثهادات، بــاب تعـديل النـسـاء بعــهـم

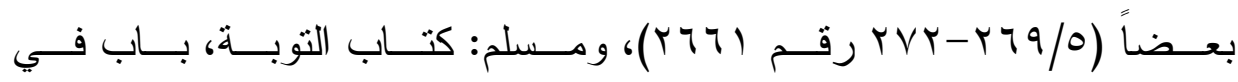

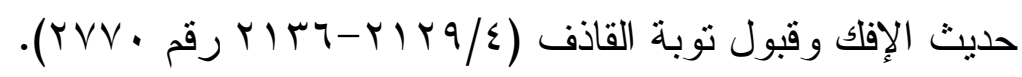

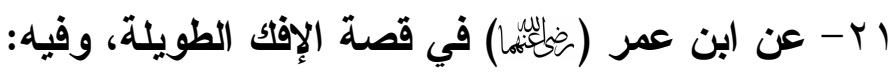

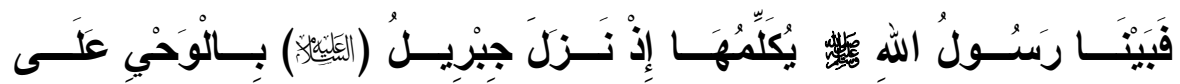
النَّبَـيِّ

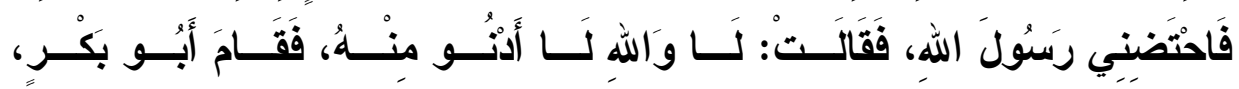

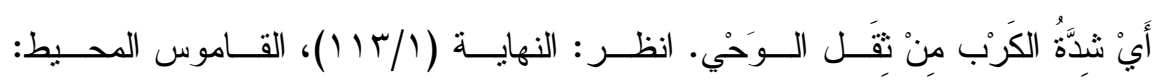

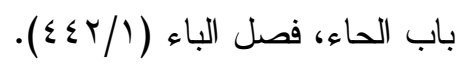




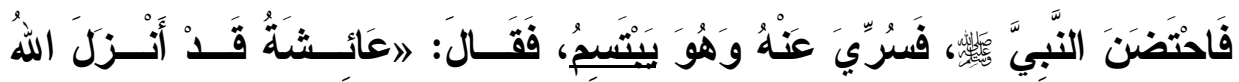

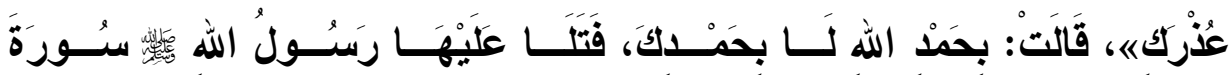

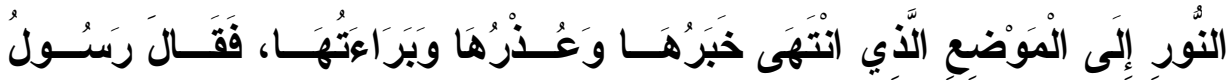

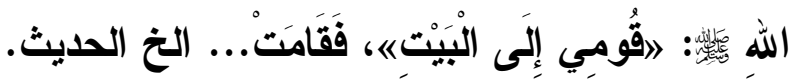

\section{تخريج الحديث:}

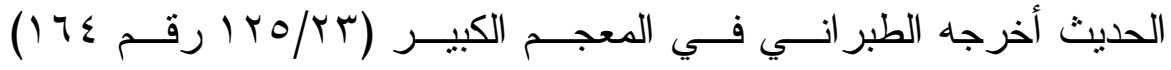
من طريق إسماعيل بن يحيى بن عبد الله التيمي عـن ابـن أبــي ذئَب عــن نافع عن ابن عمر به.

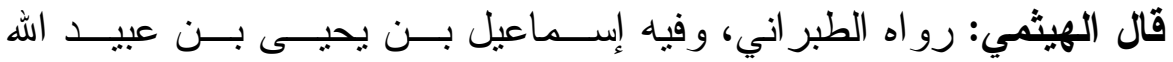
التيمي، وهو كذاب. مجمع الزو ائد (9/9 • ؟ ب).

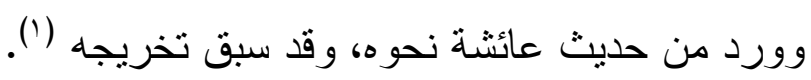

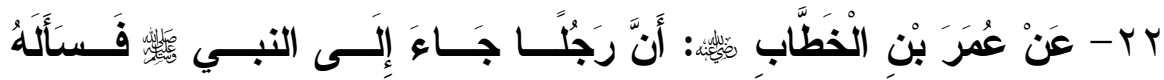

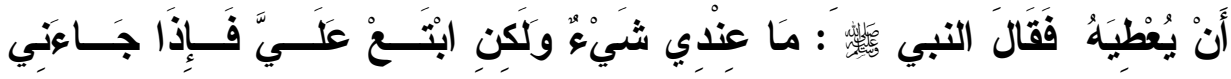

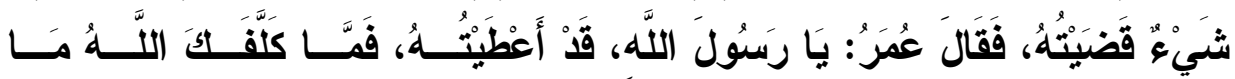

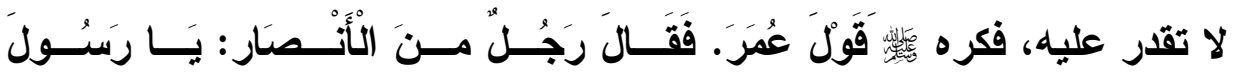

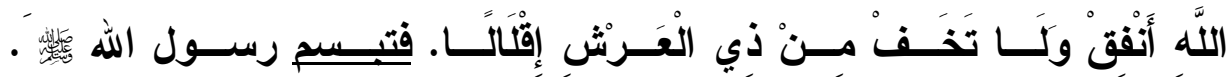

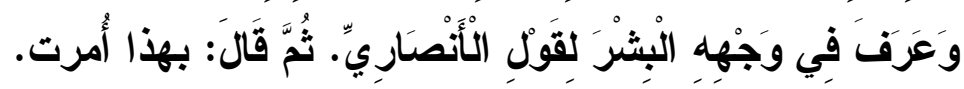




\section{تخريج الحديث:}

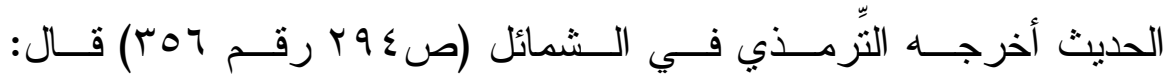

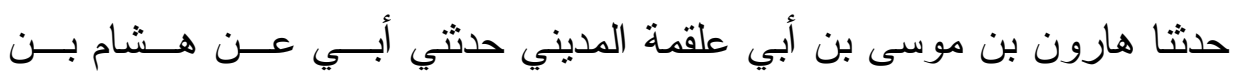

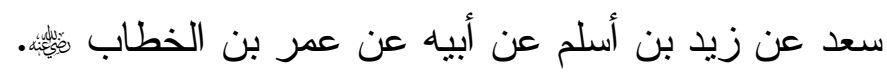
وفي إسناده موسى بن أبي علقمة، و هو مجهول. التقريب (ب9 (79).

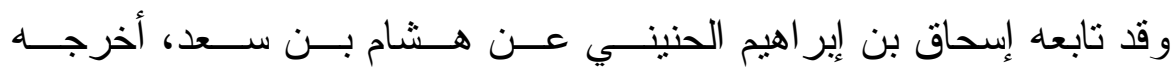

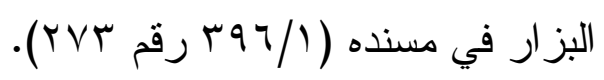

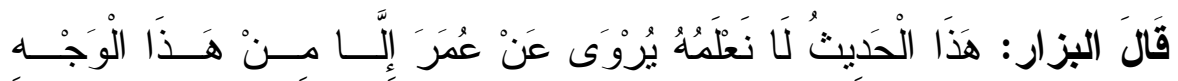

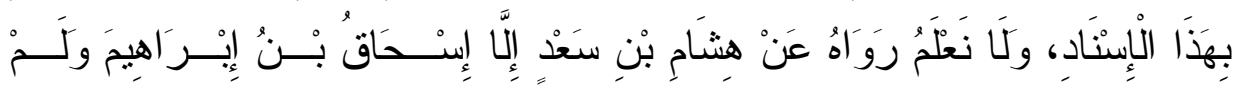
يَكُنْ بِالْحَافظـا.

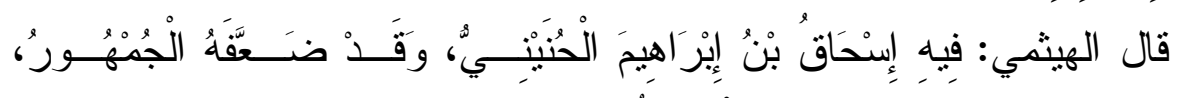

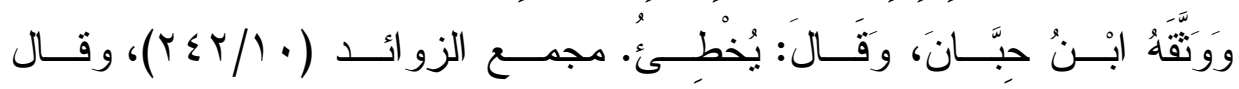
الحافظ: ضعيف. التقريب (rrv).

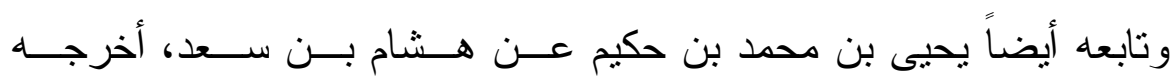

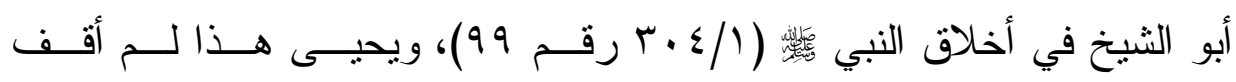
على ترجمته، وفي الإسناد إليه أيضاً عبد الله بــن شــبيب الربعـي قــال أبـــ

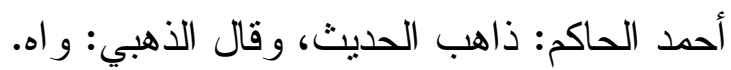

انظر: ميزان الاعتــدال (r/ ( لا ينتفع به.

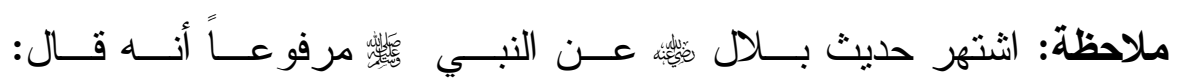

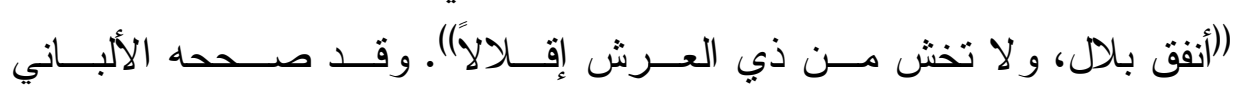

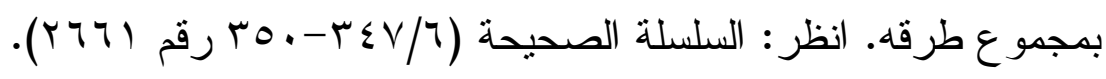




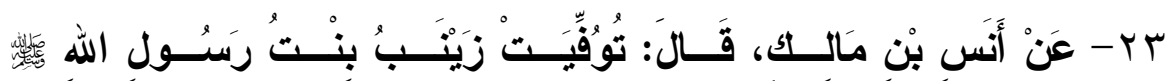

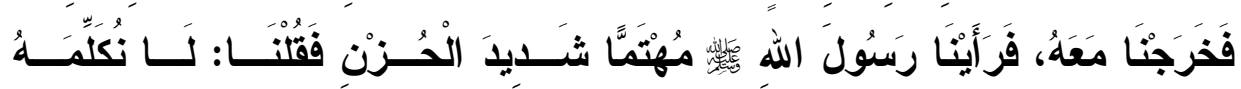

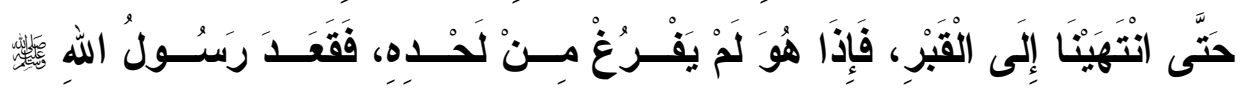

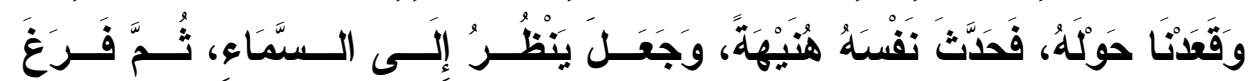

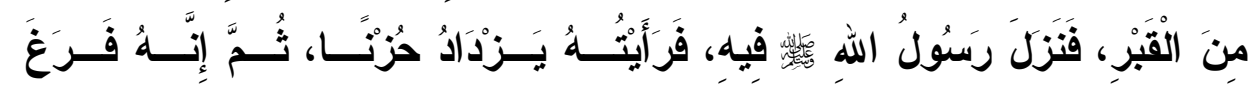

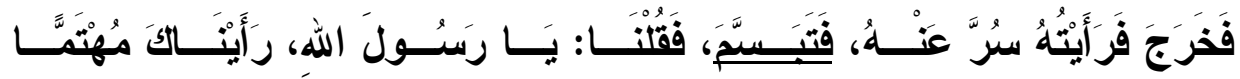

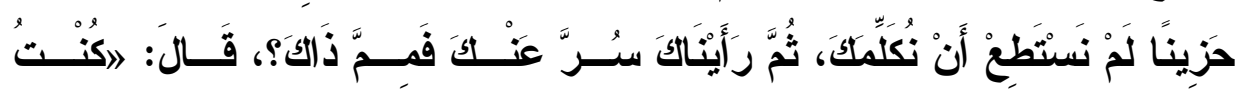

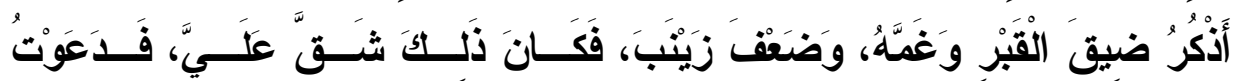

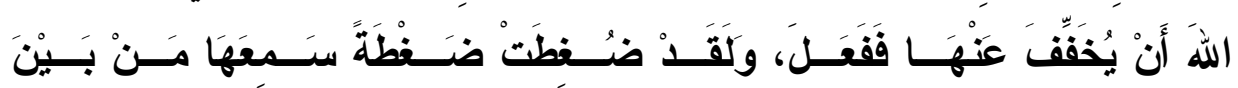

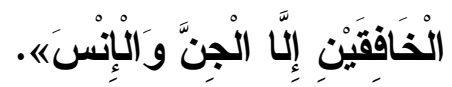

\section{تخريج الحديث:}

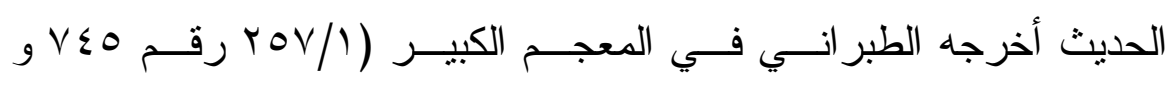

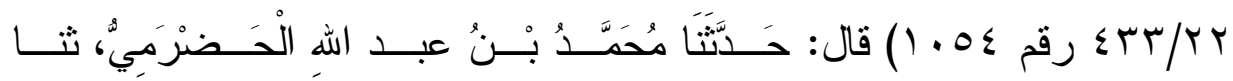

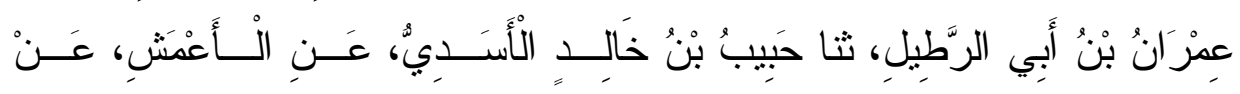

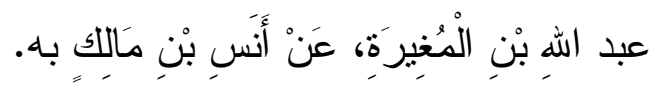

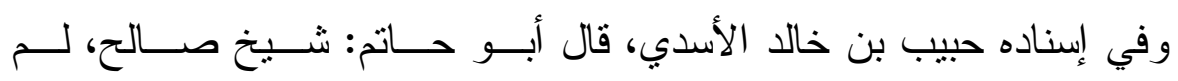

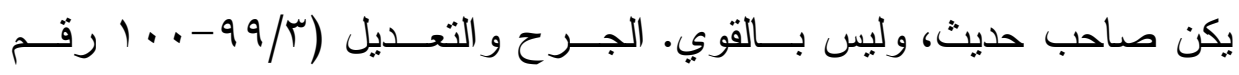
.$(\leqslant 70$

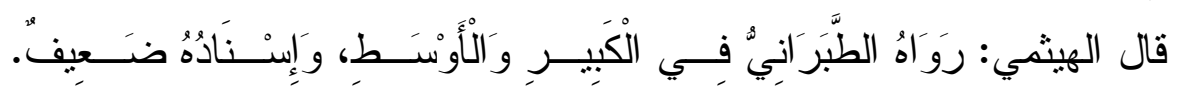

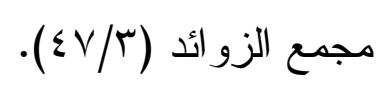

ورواية الطبر اني في الأوسط التي أنثار إليها الهيثمي سيأني ذكرها. وقد اختلف فيه على الأعمش: 
فرو اه عنه حبيب بن خالد كما سبق.

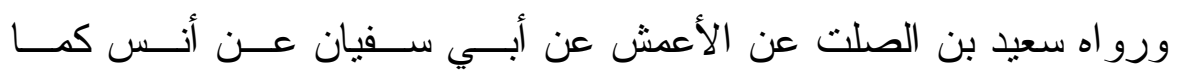

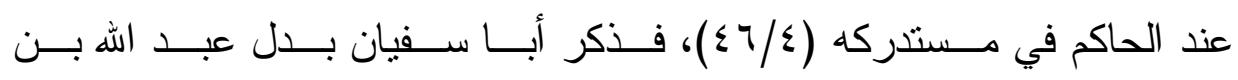

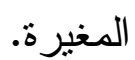

ورواه أبو حمزة السكري عن الأعمش عن سـليمان بــن المغيـرة عـنـ

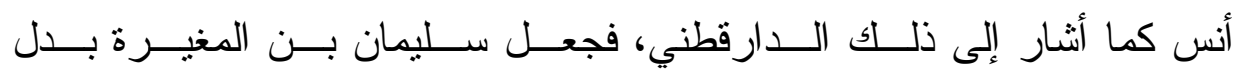
عبد الله بن المغيرة. وذكر الحديث العر اقـي فــي تخــريج الإحيــاء (TMV/T) و عز اه لابن أبي الدنيا في الموت من روايــة ســليمان الأعمـش عـنـ أنـس الأس مباشرة من غير و اسطة قال: ولم يسمع منه.

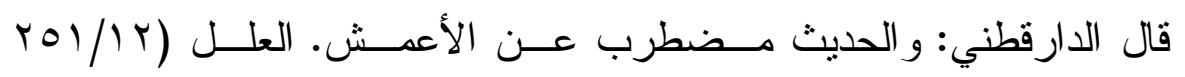

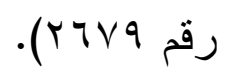

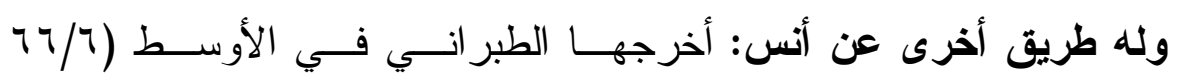

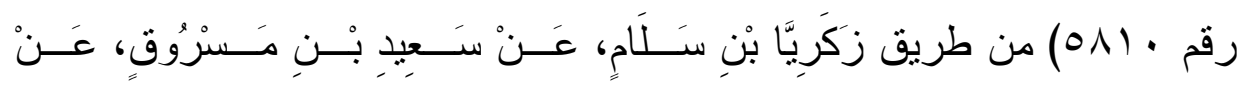

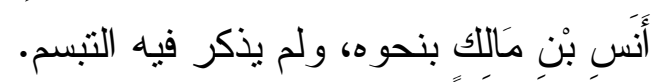

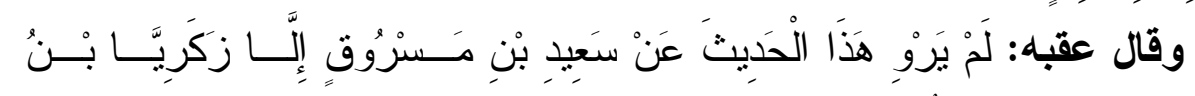

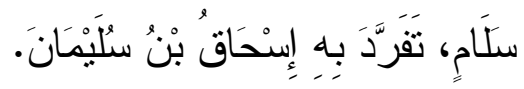

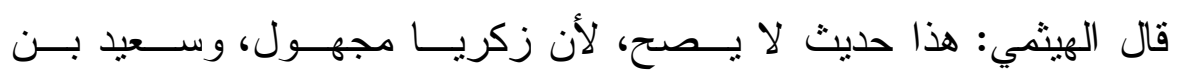

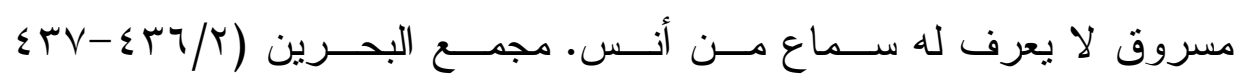

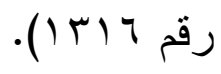


و أخرجه ابن الجوزي من طريــق زاذان عــن ابــن عمــر بنحــوه، ثـم

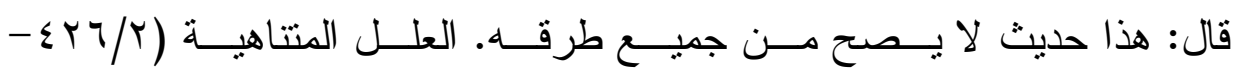

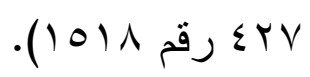

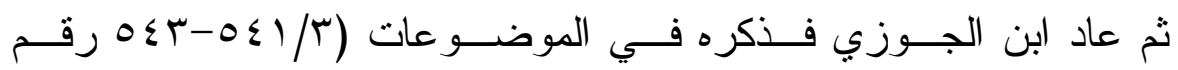
$\cdot(1) V \cdot-1 \vee \checkmark \Lambda$

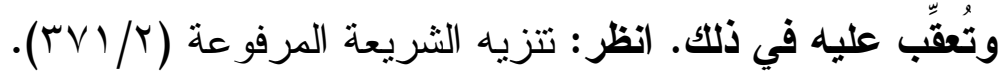
ولعل الحكم بضعفه أولى، و الله أعلم.

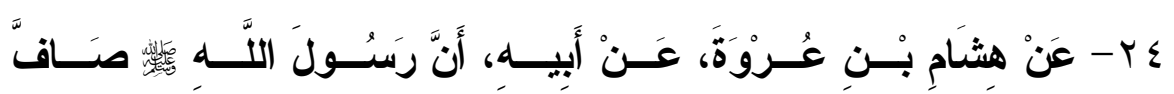

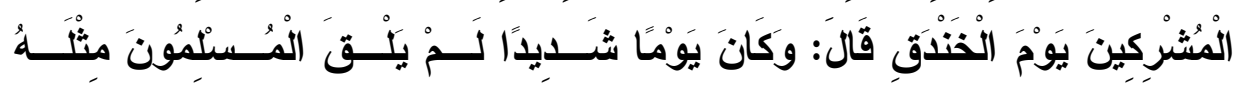

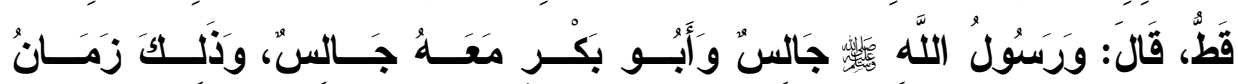

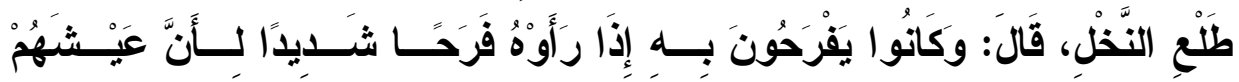

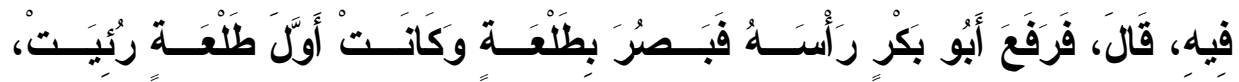

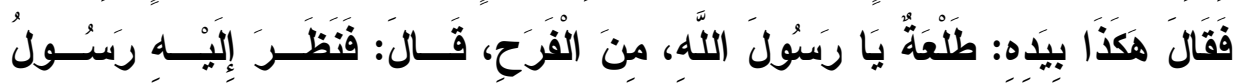

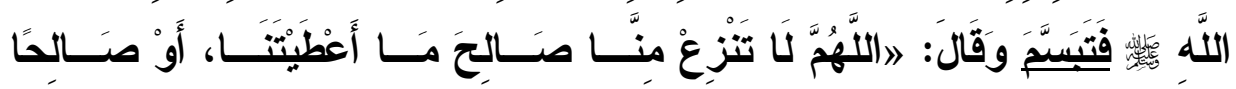
أَعْطَيْتَنَا

\section{تخريج الحديث:}

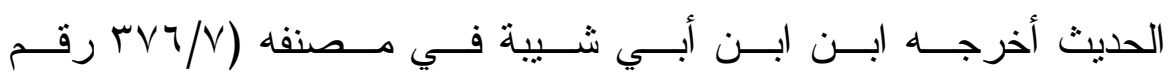

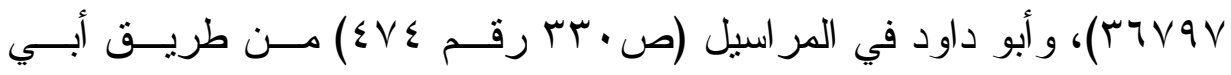

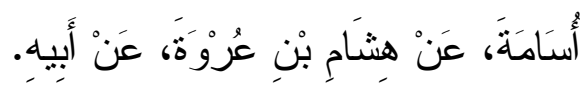

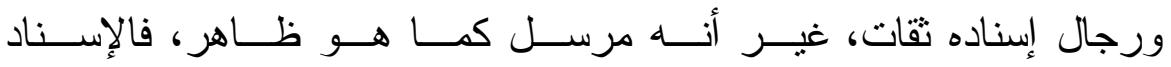

ضنعبن. 


\section{المبحث الثالث}

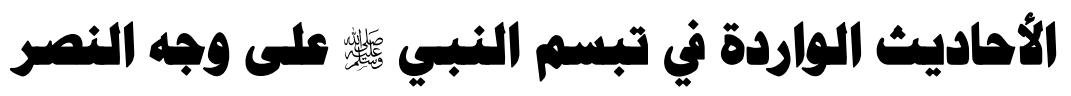 والتمبكين}

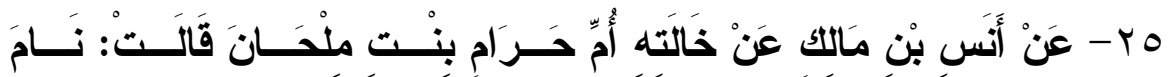

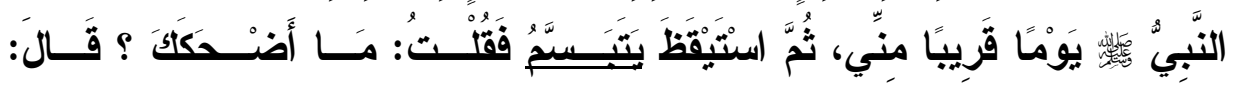

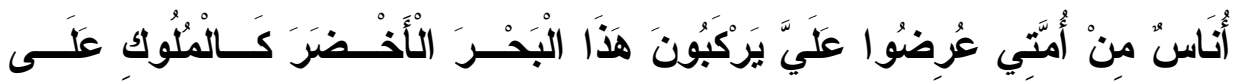

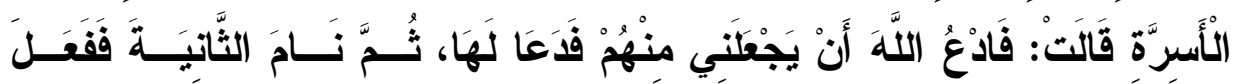

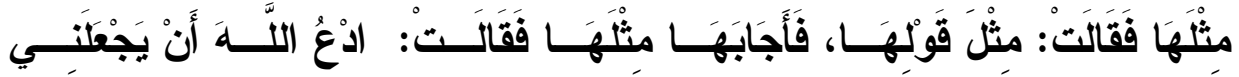

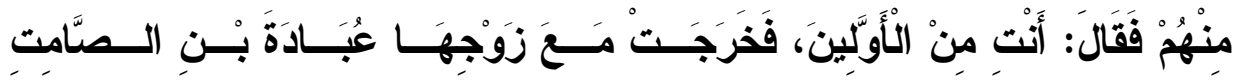

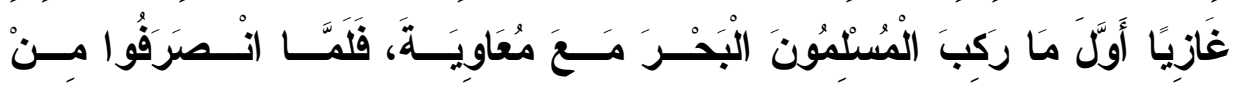

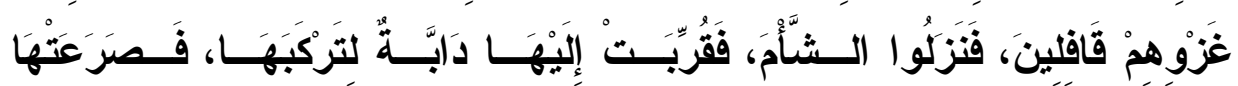
فَمَاتَتْ.

\section{تخريج الحديث:}

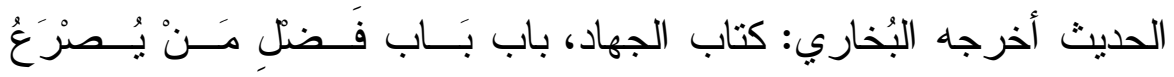

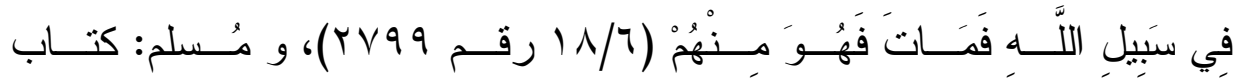

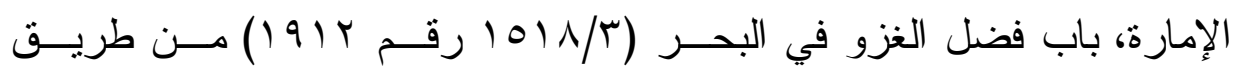
أنس بن مالك عن خالته أم حر ام بنت ملحان.

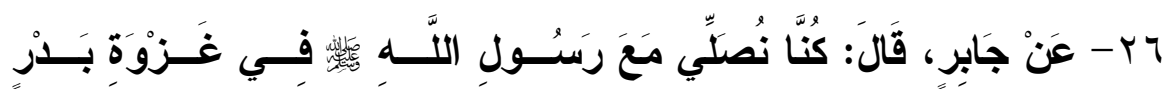

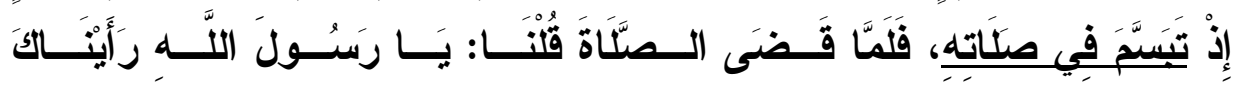

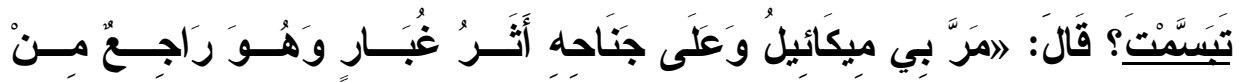

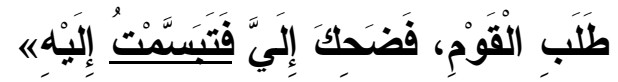




\section{تخريج الحديث:}

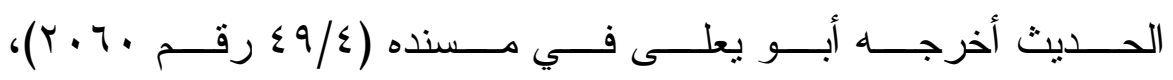

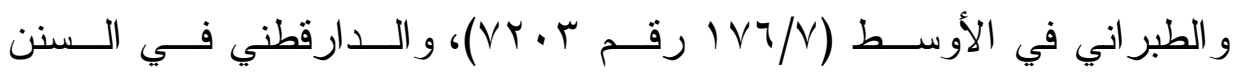

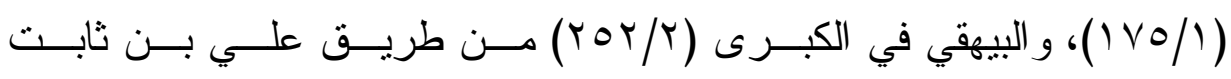

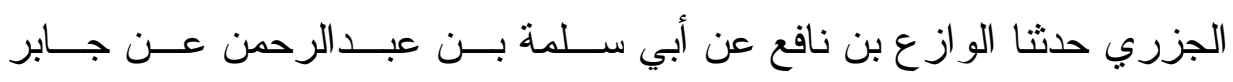
فذكره.

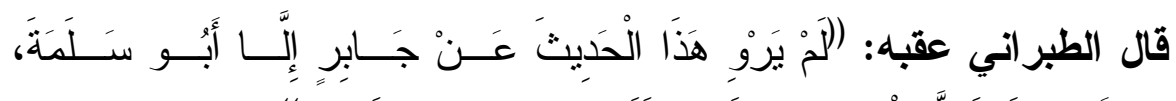

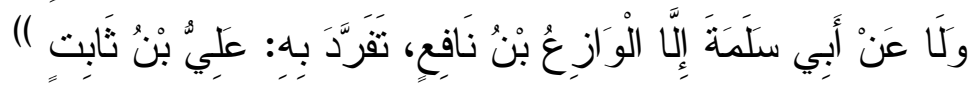

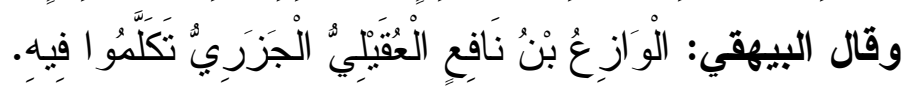

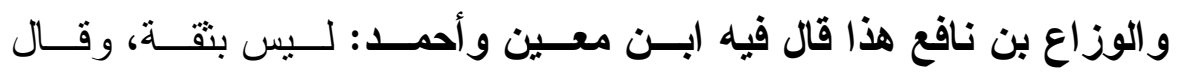

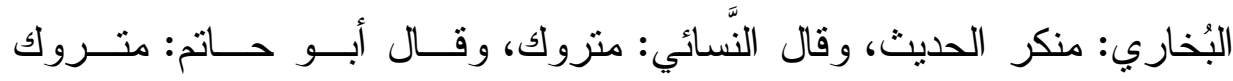
الحديث.

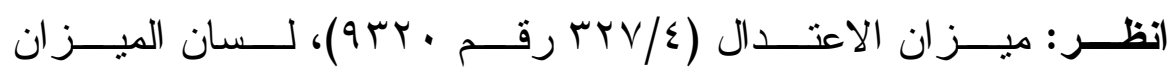

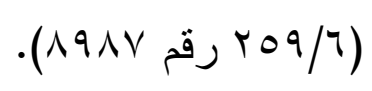

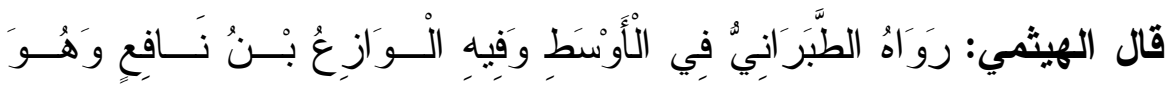

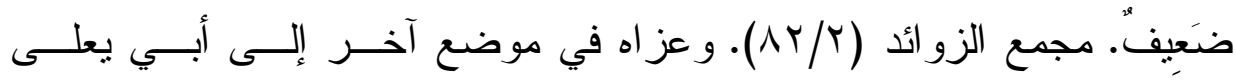

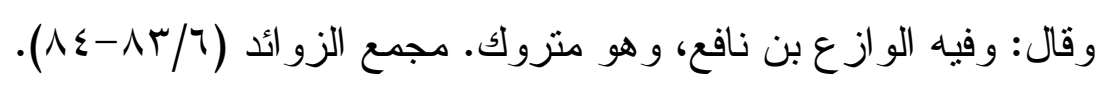




\section{المبحث الرابع}

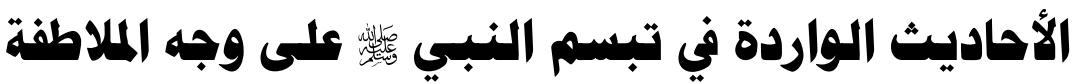

\section{والانبساط}

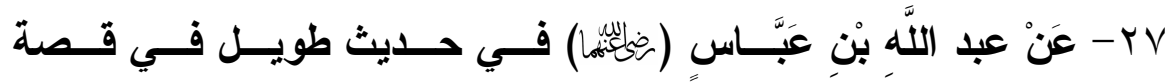

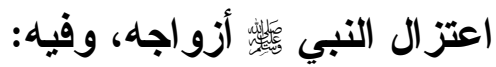

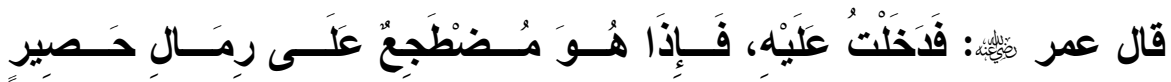

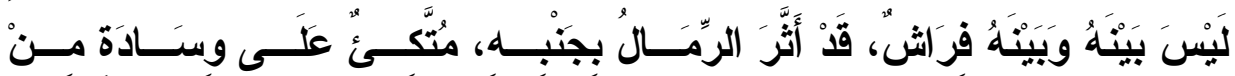

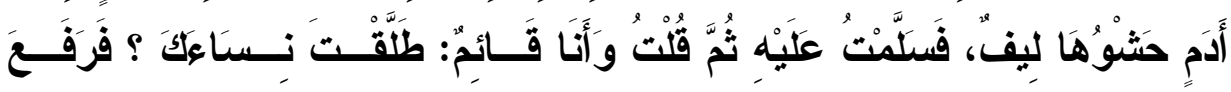

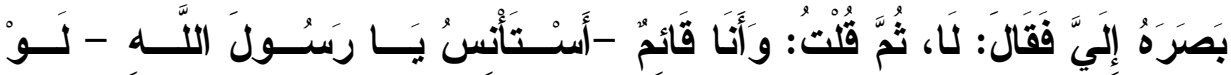

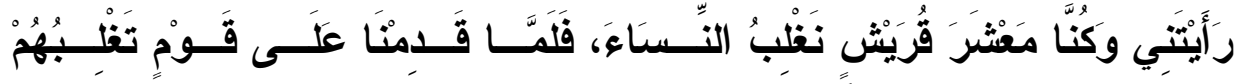

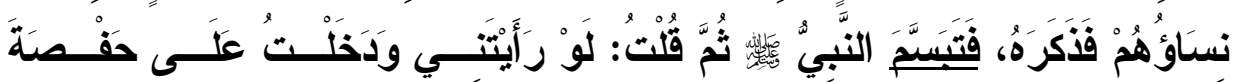

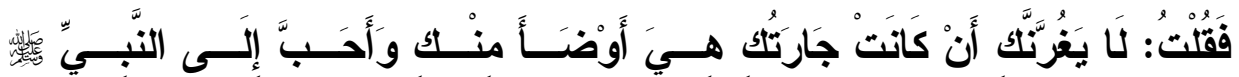

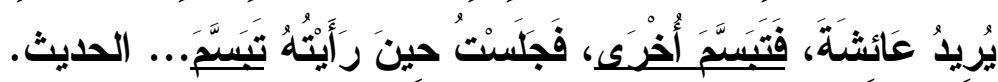

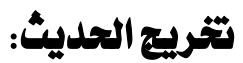

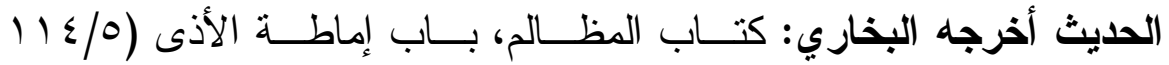

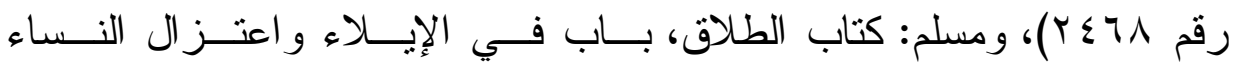

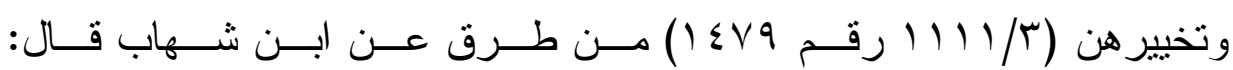
أخبرني عبيد الله بن عبد الله بن أبي ثور عن ابن عباس (خفلائما).

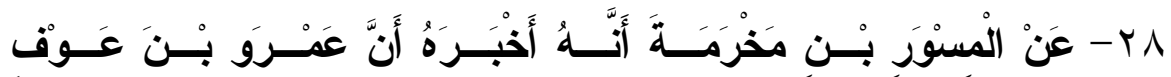

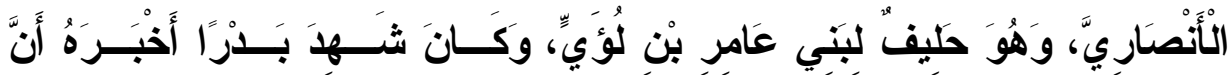
رَسنولَ اللَّهَ 


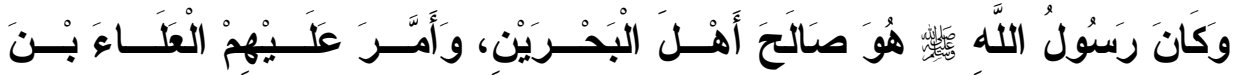

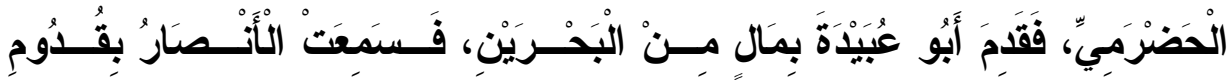

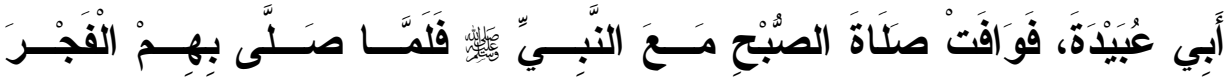

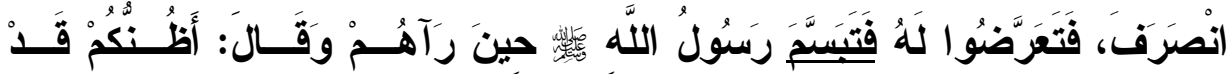

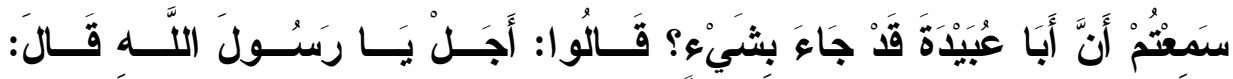

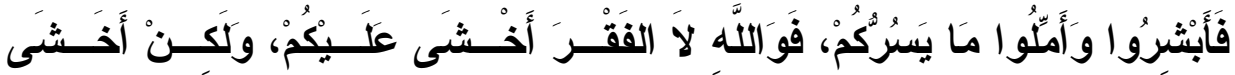

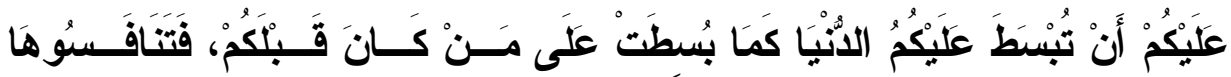

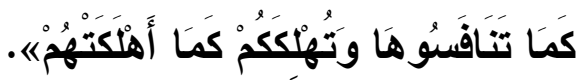

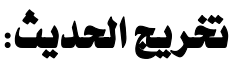

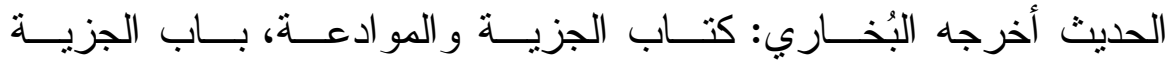

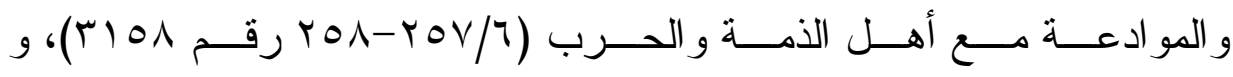

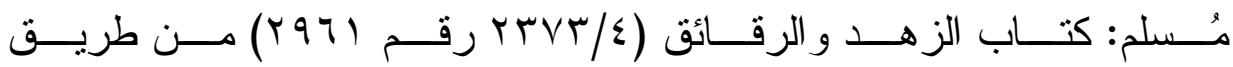

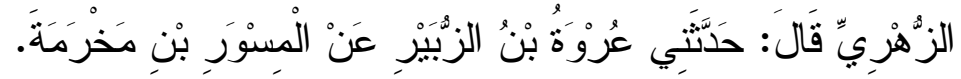

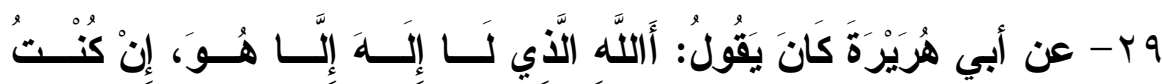

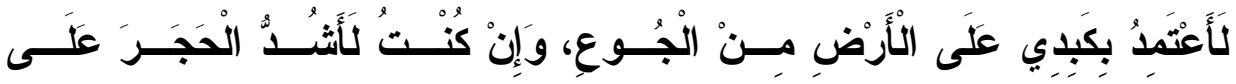

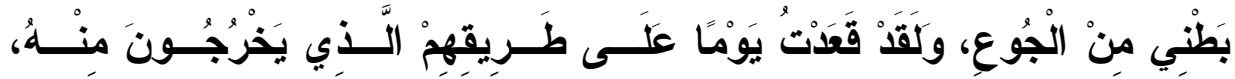

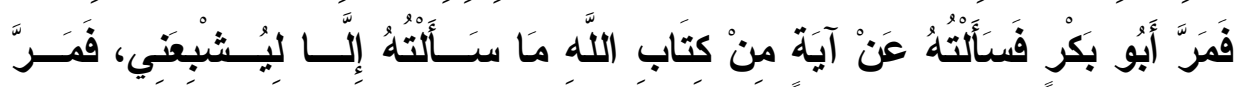

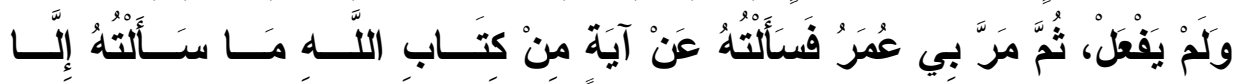

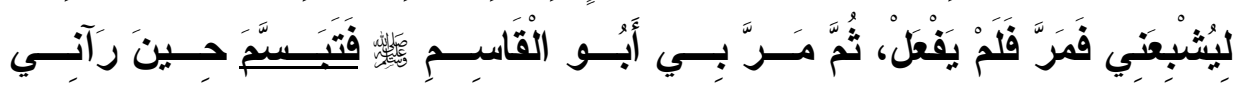

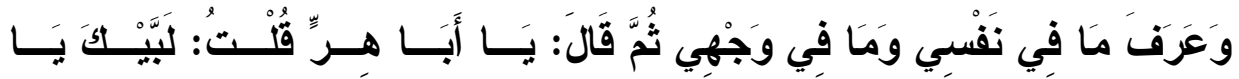

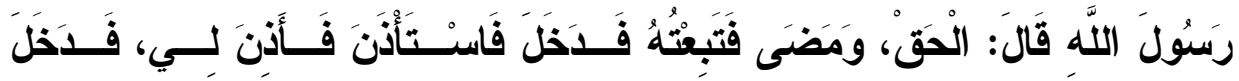

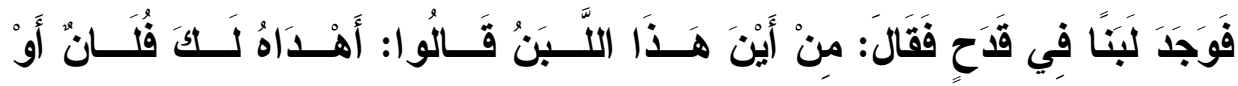




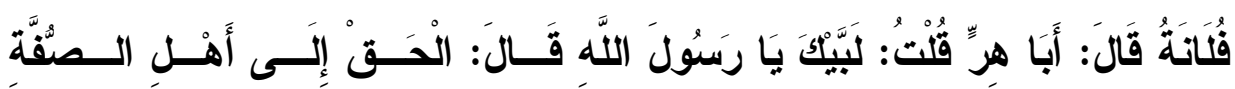

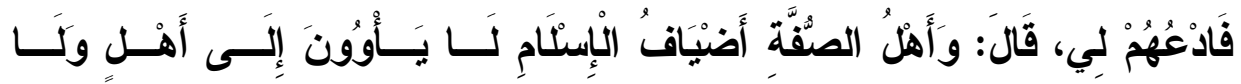

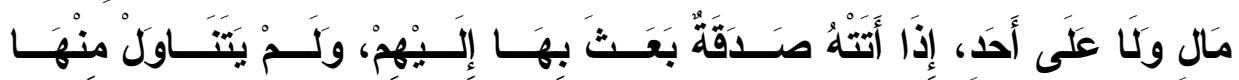

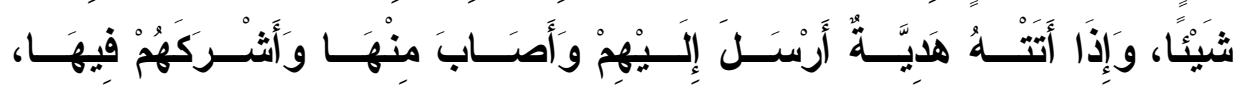

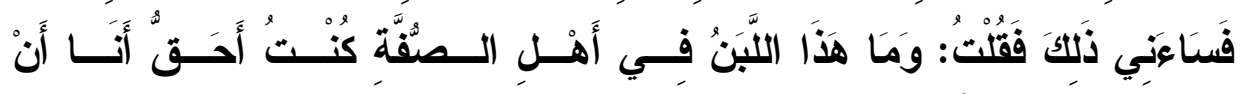

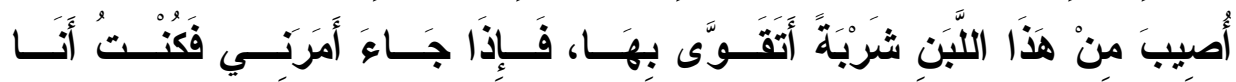

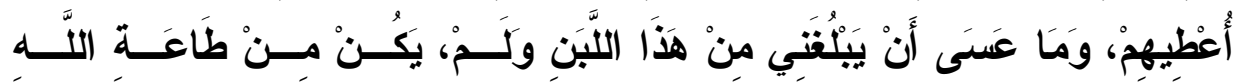

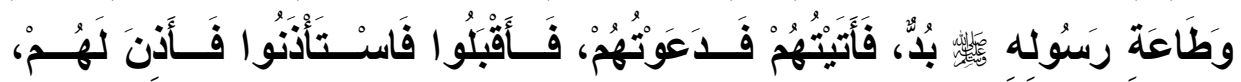

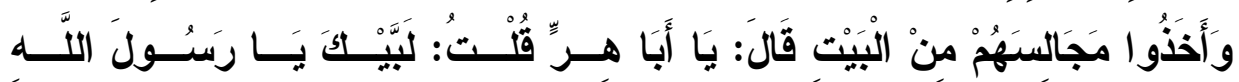

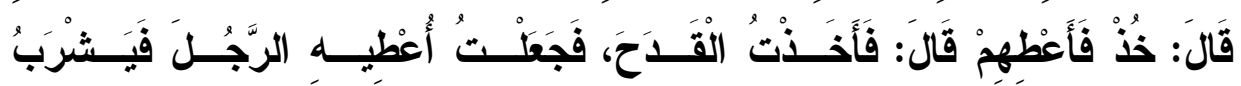

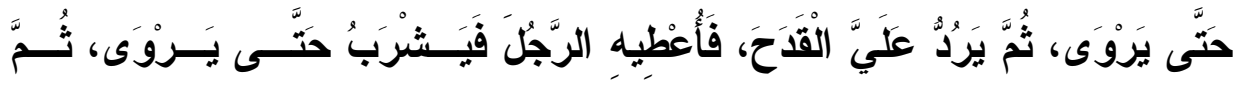

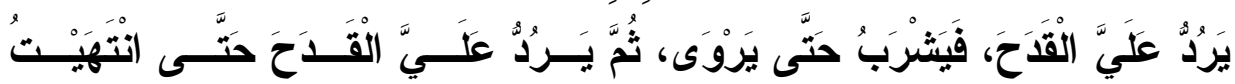
إِلَى النَّبَِّ

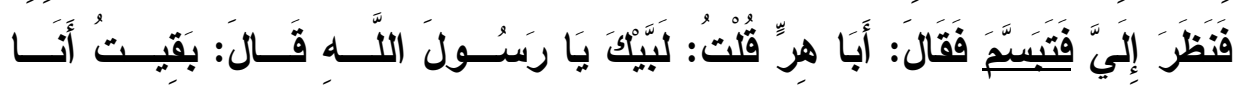

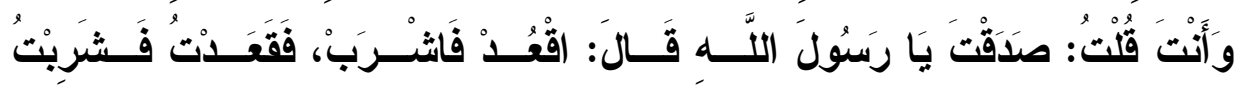

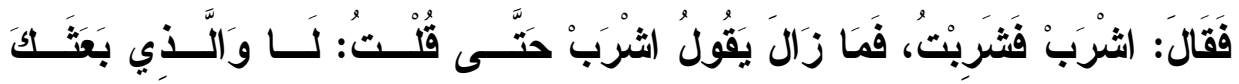

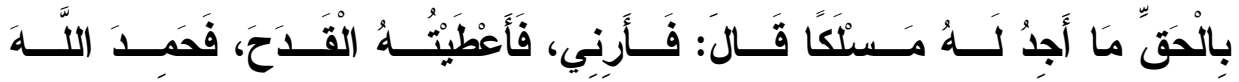

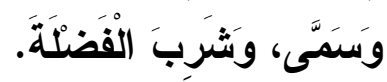

\section{تخريج الحديث:}

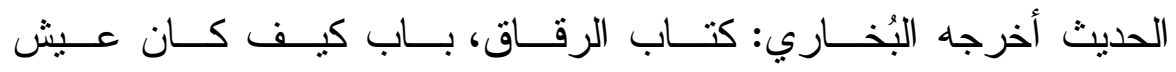

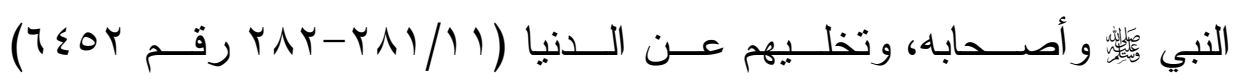
من طريق مجاهد عن أبي هريرة ونئ. 


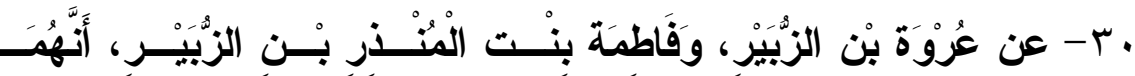

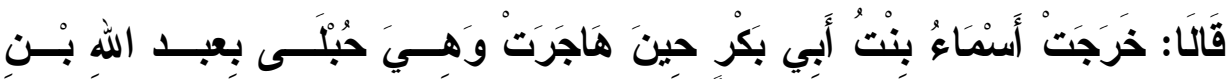

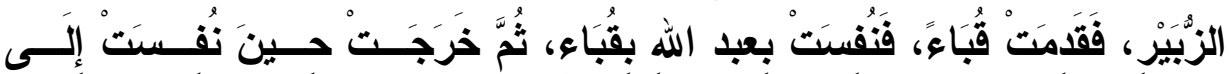

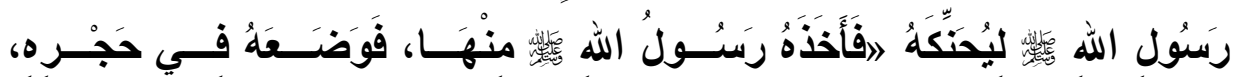

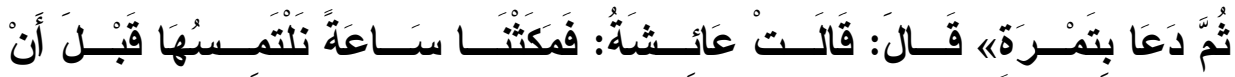

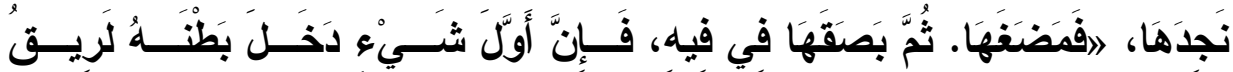

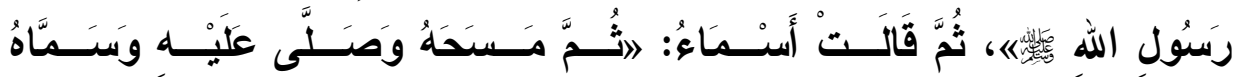

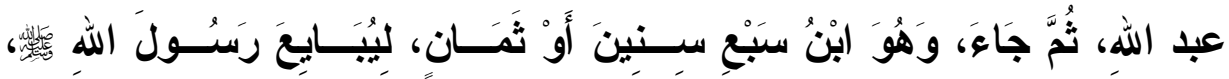

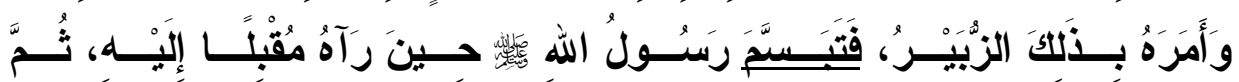
بَايَعَهُهُ .

\section{تخريج الحديث:}

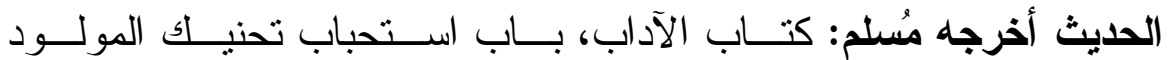

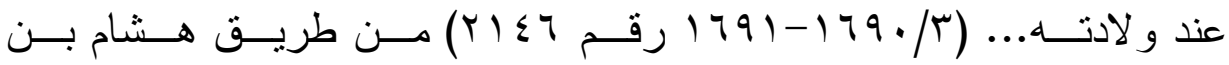
عروة عن عروة وفاطمة به.

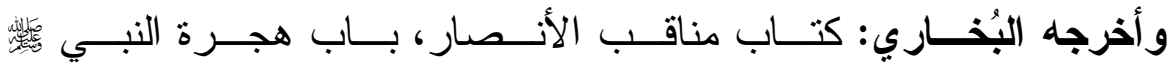

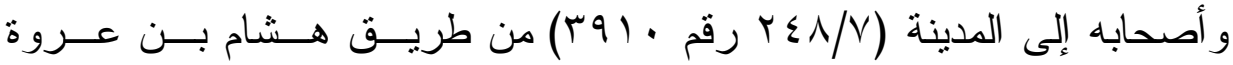
عن أبيه عن عائشة مختصر ا، وليس عنده موضع الثاهد في التبسم.

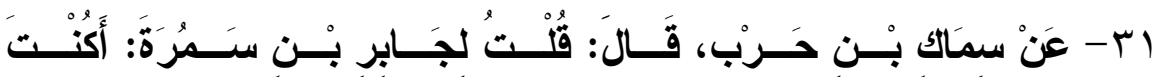

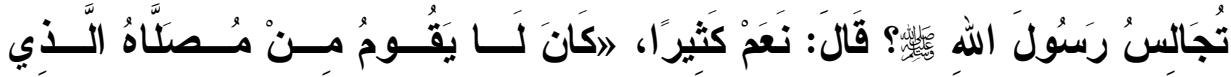

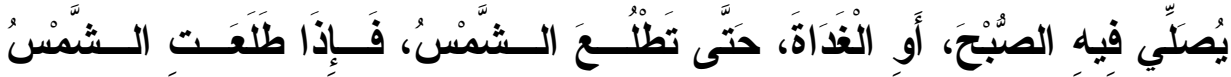

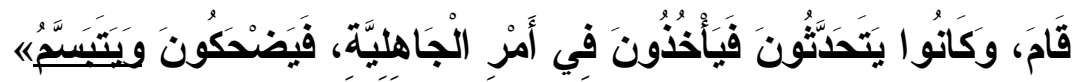




\section{تخريج الحديث:}

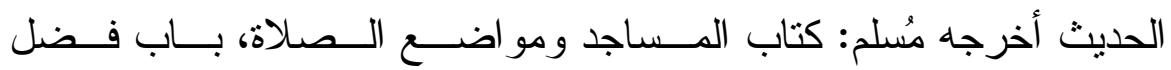

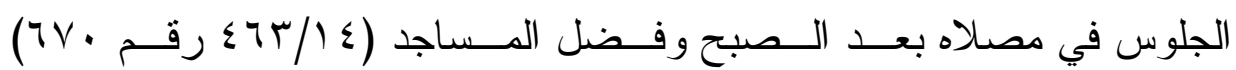
من طريق أبي خيثمة عن سماك بن حرب.

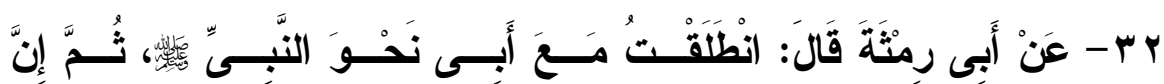

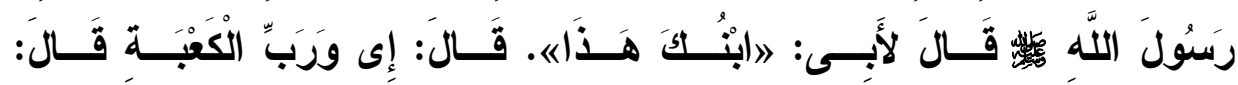

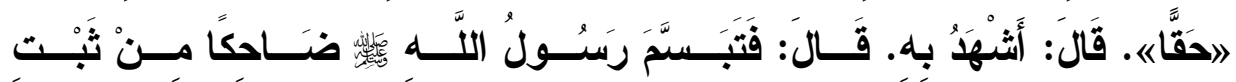

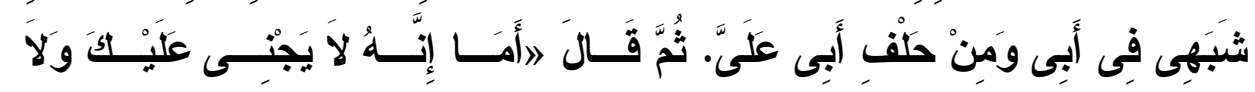

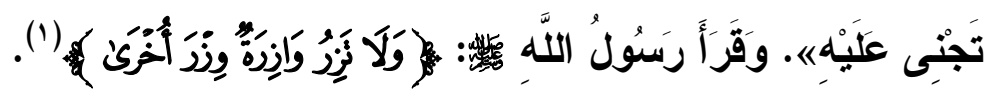

\section{تخريج الحديث:}

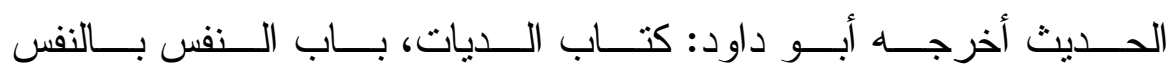

(§/T)

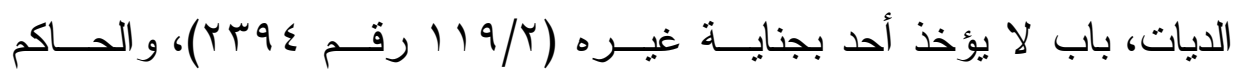

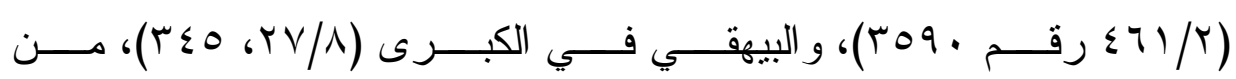

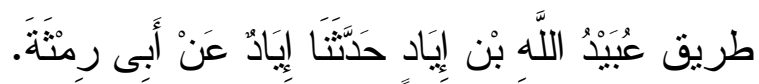
قال الحاكم: صحيح الإسناد ولم يخرجاه.

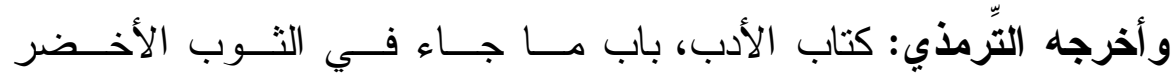

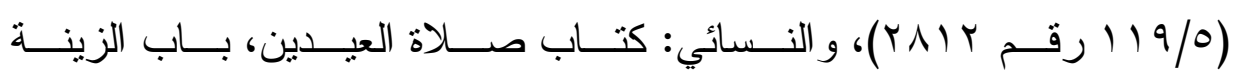
(1) سورة الأنعام: آية رقم (ع 1 (1)، ومواضع أخرى أيضاً في القرآن الكريم. 


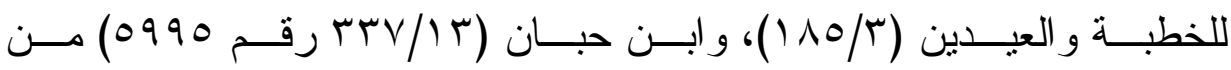

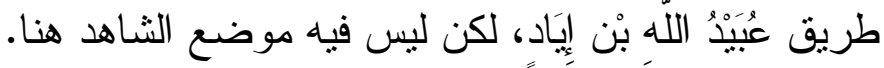

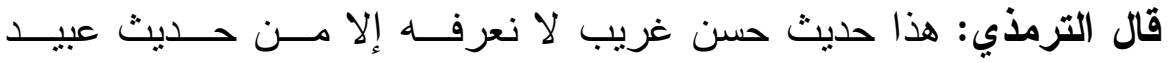
الله بن إياد، و أبو رمثه التيمي يقال: اسمه حبيب بــن حيــان، ويقــال اســـهـ: رفاعة بن بثربي.

وفي إسناده: عبيد الله بن إياد بـن لقـيط الـسـدوسي أبــو الـسَّليل قــال

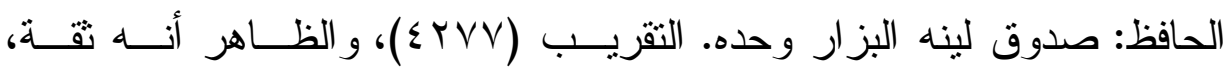

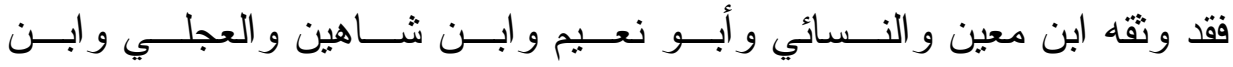
حبان. انظر : تهذيب التهذيب (ع/V)

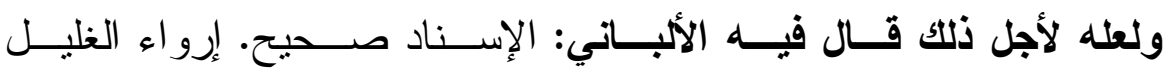
(r/V)

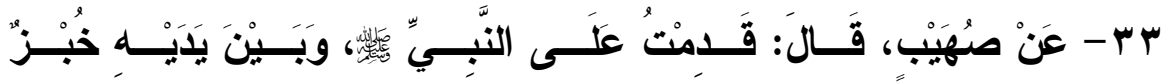

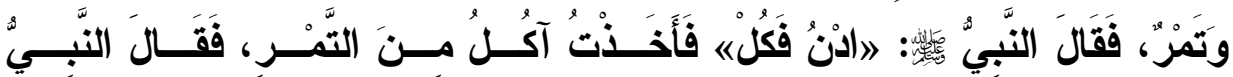

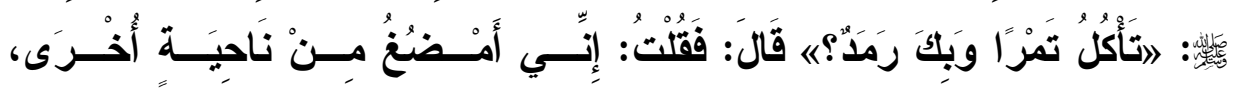

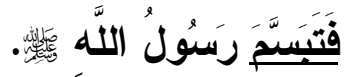

\section{تخريج الحديث:}

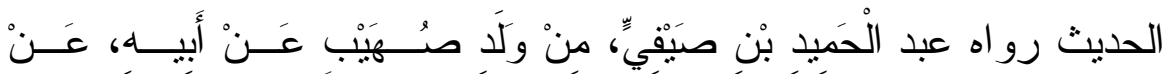

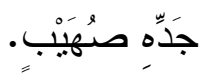
ورواه عن عبد الحميد هذا:عبد الله بـن المبــارك، وداود بــن إســماعيل بن مجمع: 


\section{أولأ: دوايل ابن المبارك:}

اختلف فيه على ابن المبارك:

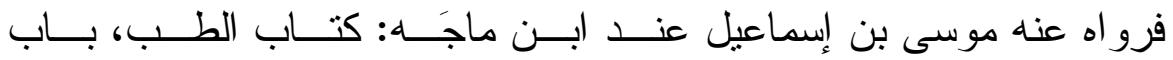

$$
\text { الحمية (r/ }
$$

وسعيد بن سليمان الواسطي عند الحاكم (T// (0) )،

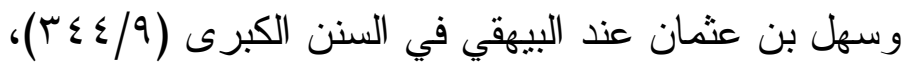

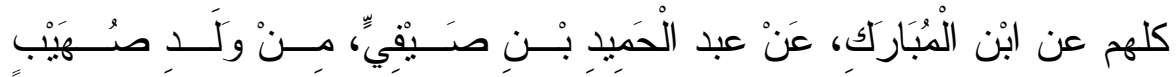

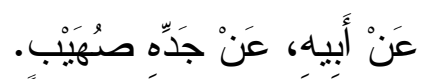

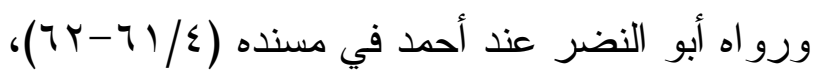

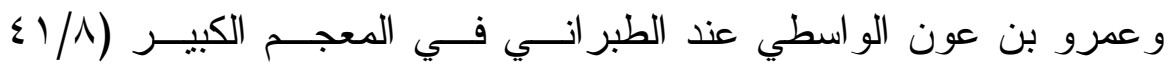
رقم ع. (VT)

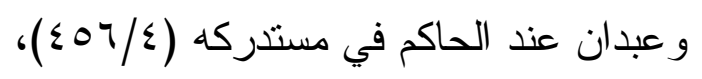

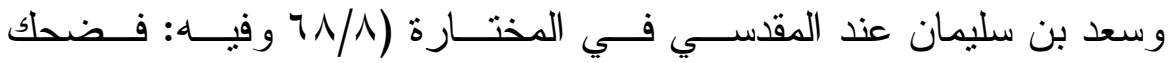

بدل تبسم)،

كلهم عن عبد الله بن المبارك ثثا عبد الحميــد بـن صــيفي رجــل مــن ولا صهيب عن أبيه عن جده قال: إن صهيبا قدم... فذكره مرسلاً.

و اختلف في اسم عبد الحميد بن صــيفي هــذا فأغلــب الروايــات علــى

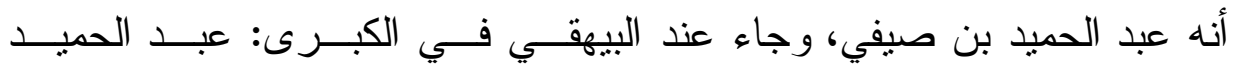

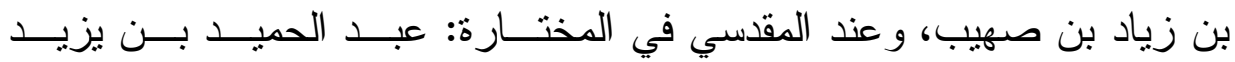
بن صيفي بن صهيب. 


\section{ثُانياً: رواية داود بن إسماعيل بن مجمع:}

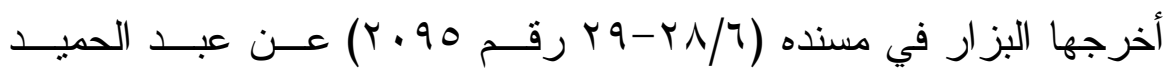

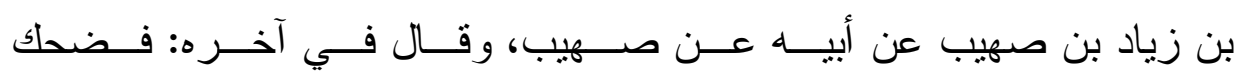
رسول الله

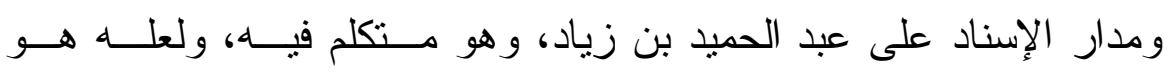

سبب هذا الاختلاف حيث لم يضبط سنده ('):

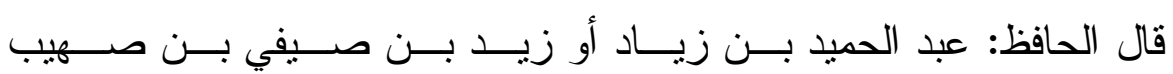
الرومي، وربما نسب إلى جده، لين الحديث. التقريب ( • (YVT).

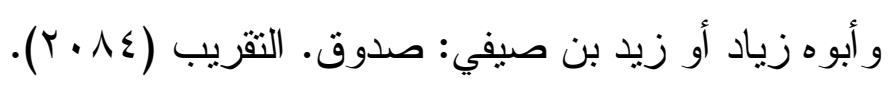

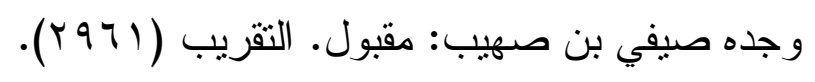

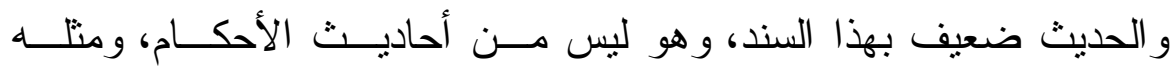

في الباب يحتمل، ولعل ذللك سبب من قوّاه: قال الحاكم: صحيح الإسناد ولم يخرجاه.

وعز اه العراقي لابن ماجه وقـال: بإســناد جيــد، وفــي موضــع آخــر

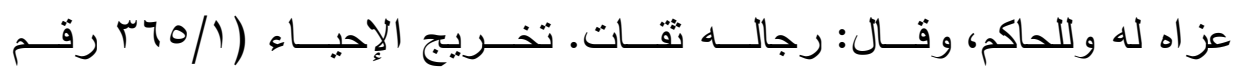

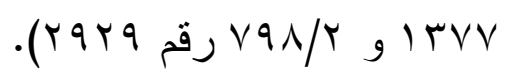

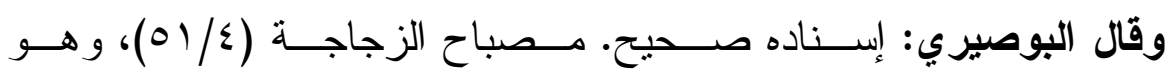
بعيد في مثل حال هذا الحديث، و الله أعلم.

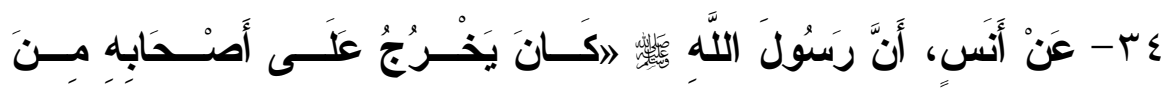

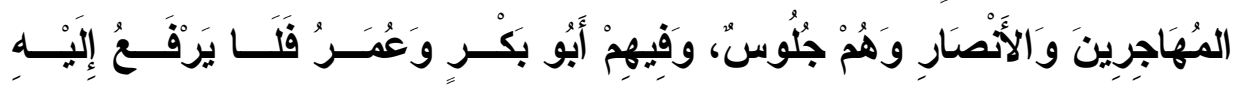




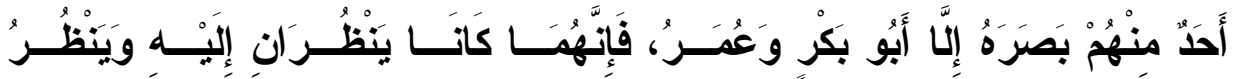

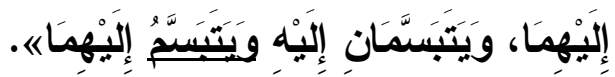

\section{تخريج الحديث:}

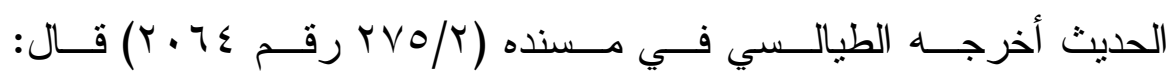

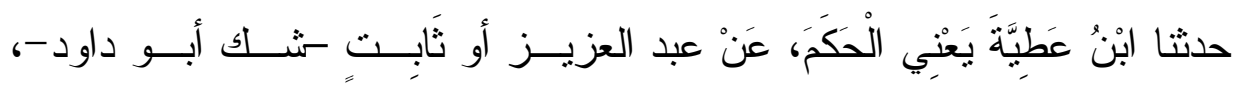
عَنْ أَنَس.

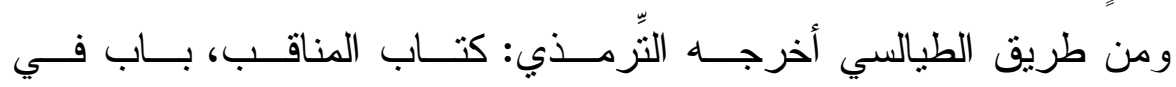

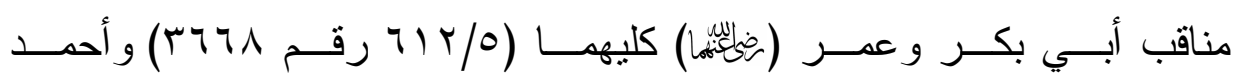

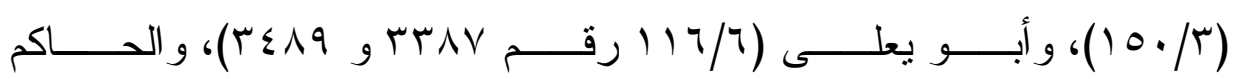

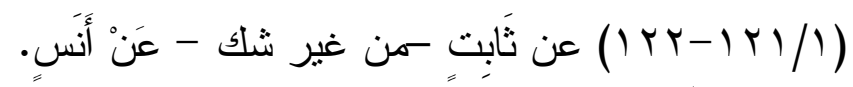

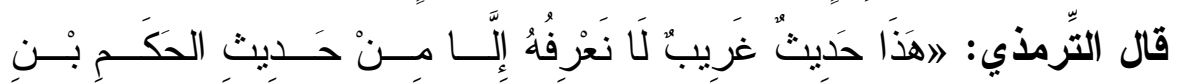

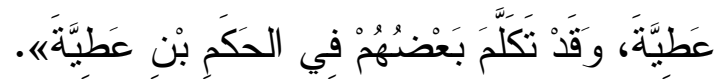

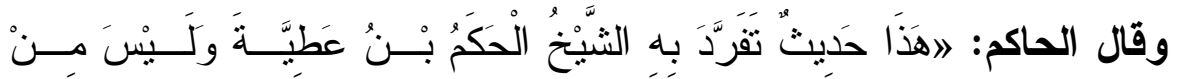

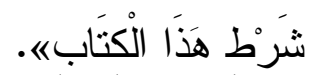

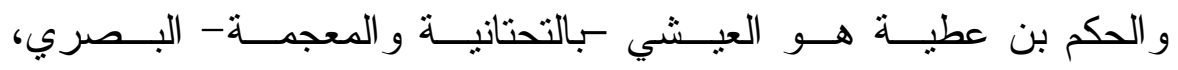

$$
\text { صدوق لله أوهام. التقريب (00 بـ ( ). }
$$

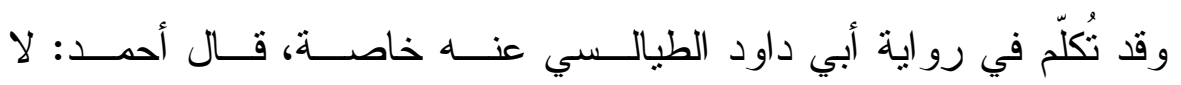

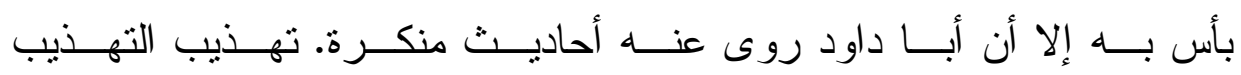
. ( $\left\{r \uparrow-\varepsilon \Gamma_{0} / \zeta\right)$

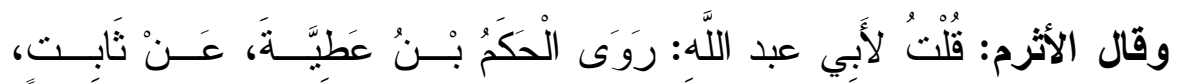

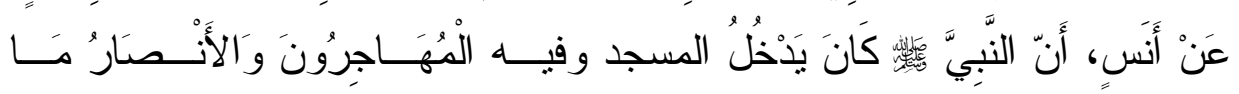




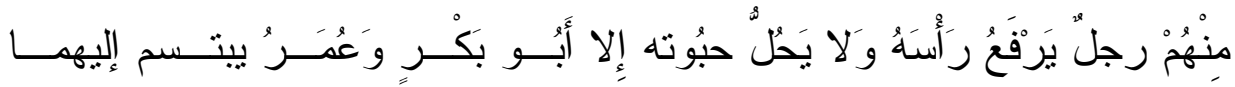
ويبتسمان إلَيْهِه - فَأَنْكَرَهُ.

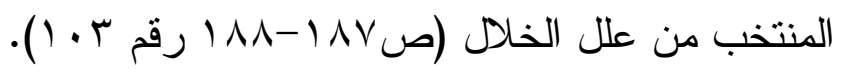

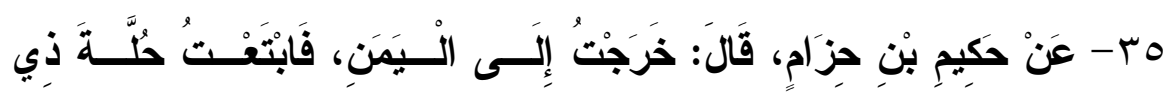

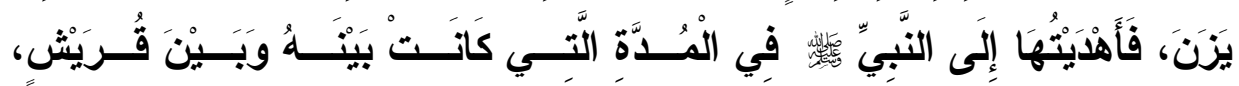

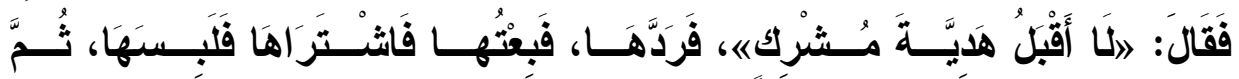

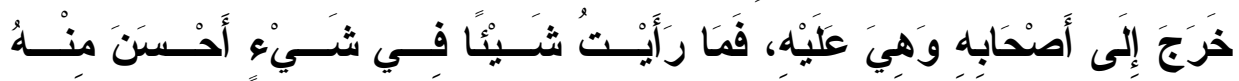

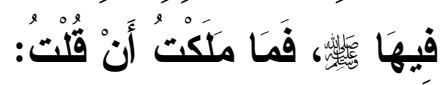

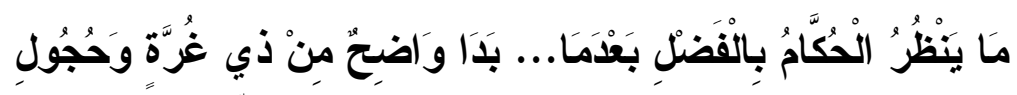

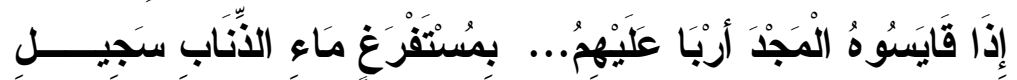
فَسَمَعَهُ رَسنولُ اللهِ بَنْ زَيْدِ

\section{تخريج الحديث:}

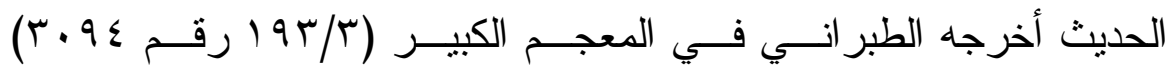

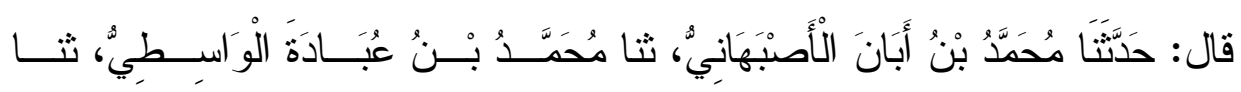

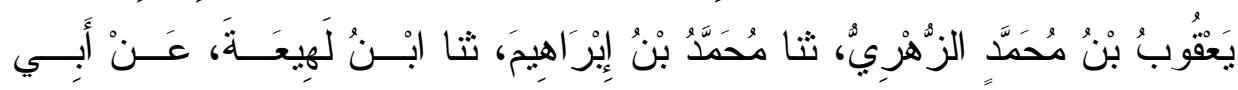

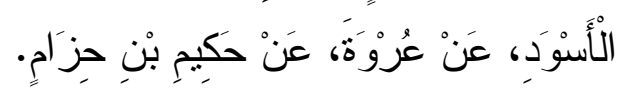

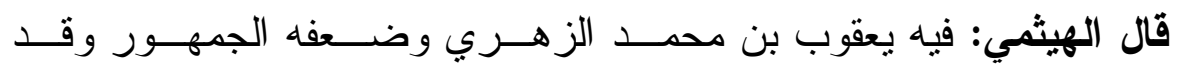

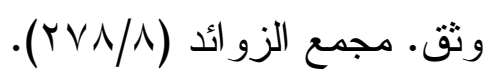

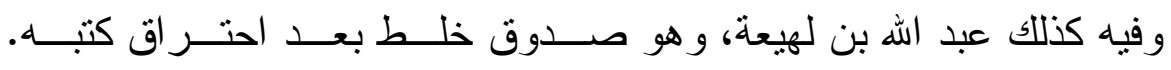

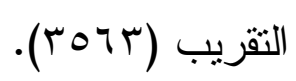




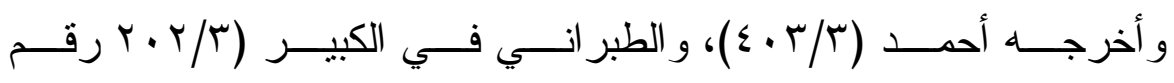

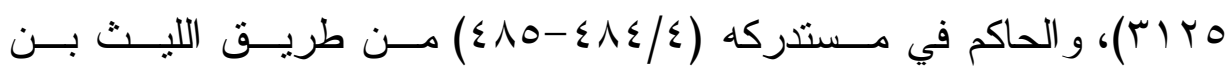

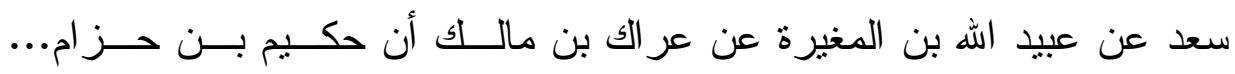

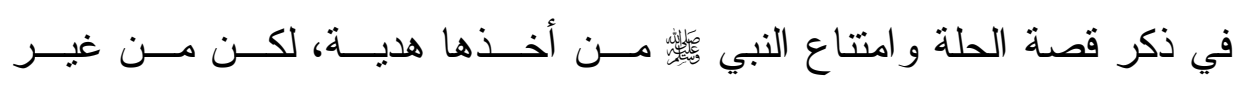

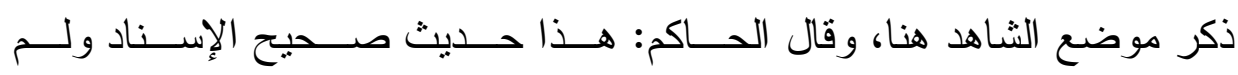
يخرجاه.

قال الهيثمي: رو اه أحمد و الطبر اني في الكبيــر و إســناده جيــد، رجاهـــه تقات. مجمع الزو ائد (ع/ (10)).

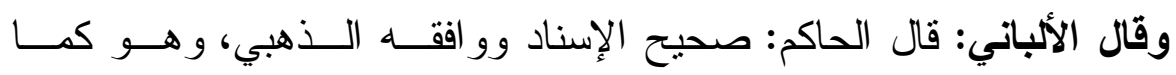

قالا.

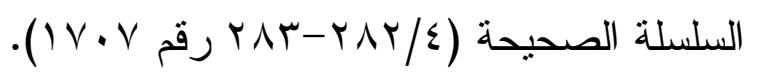

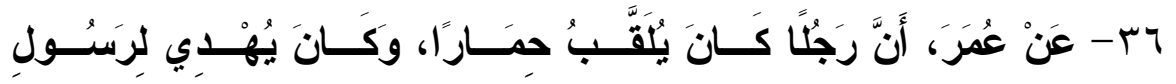

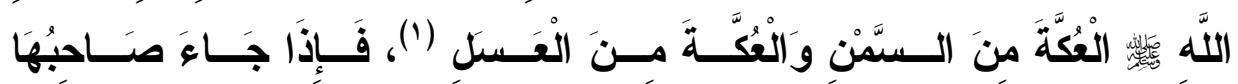

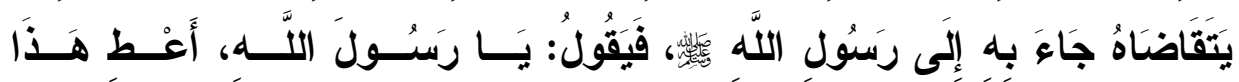

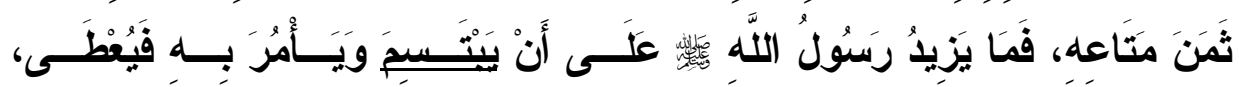

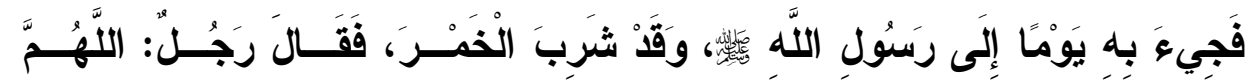

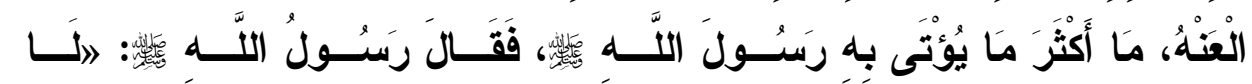

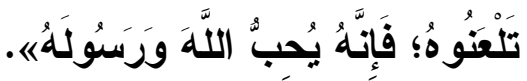

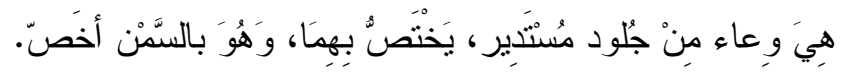

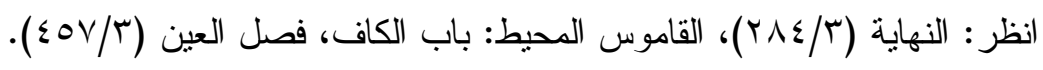




\section{تخريج الحديث:}

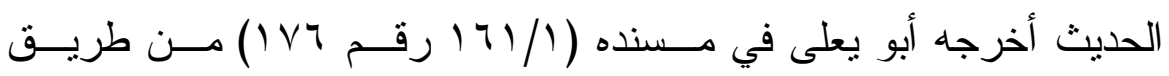

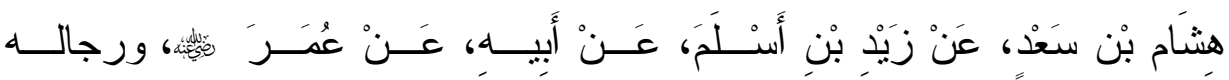

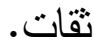

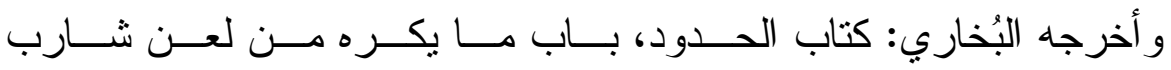

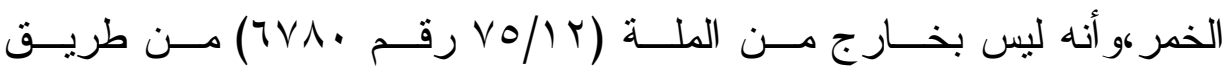

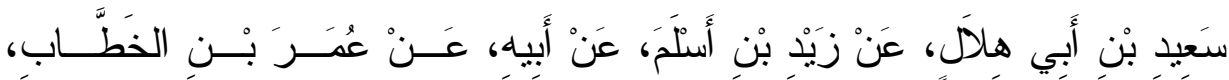

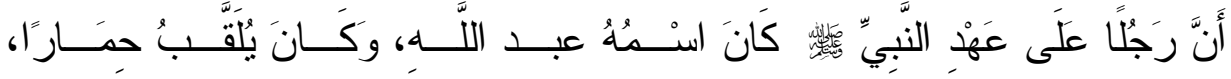

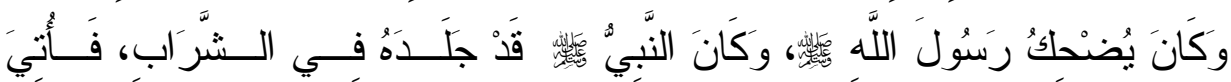

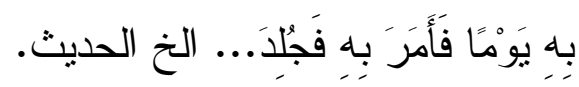

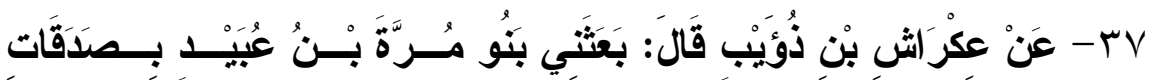

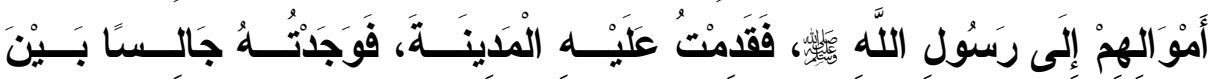

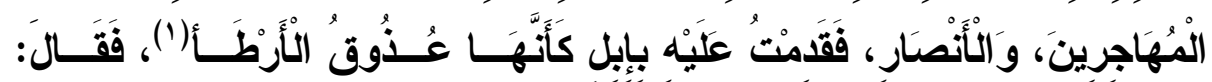

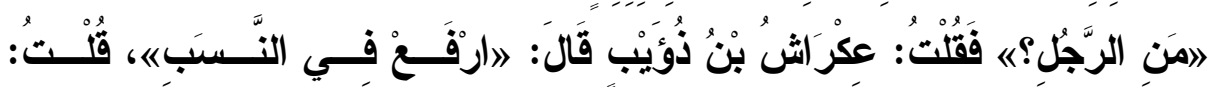

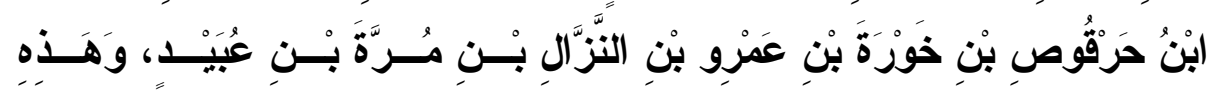

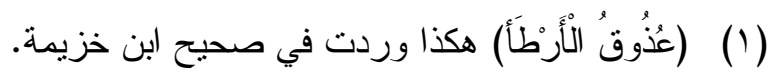

وعند الطبر (عن في الأوسط: (عروق الأمطا)، وفي الكبير (عروق الأرطى).

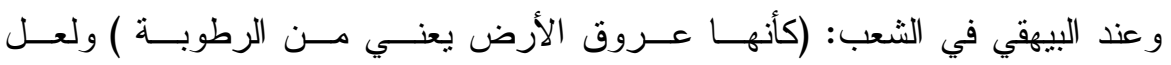

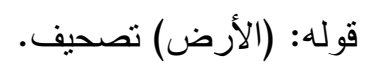

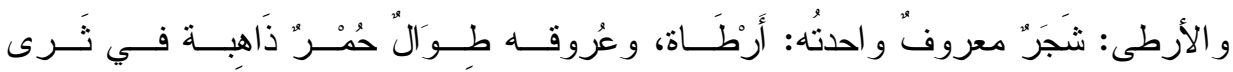

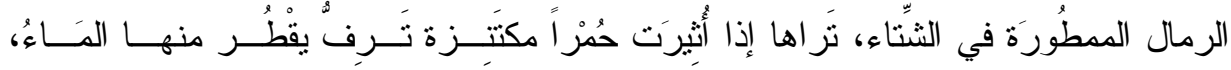

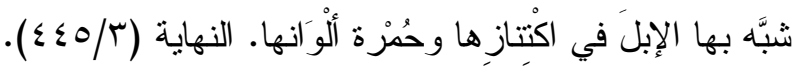




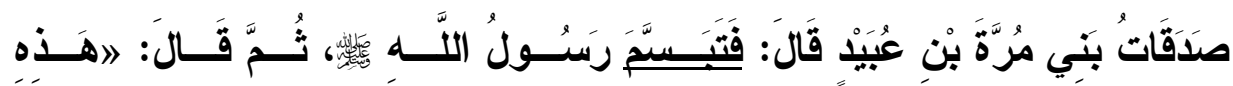

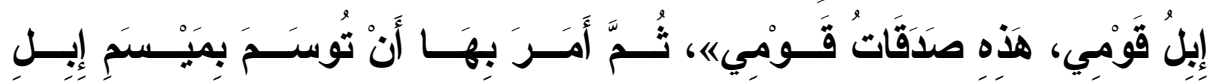

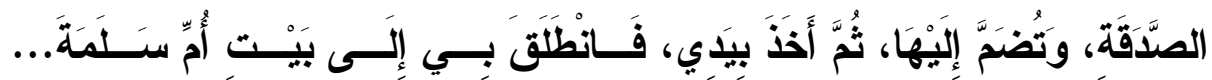
فَذَكَرَ الْحَديثَ.

\section{تخريج الحديث:}

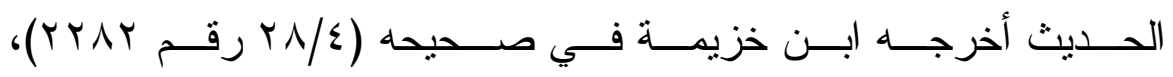

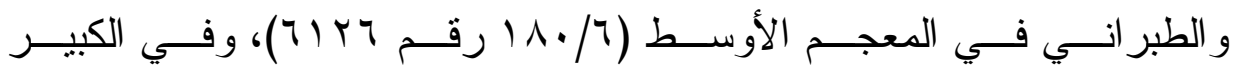

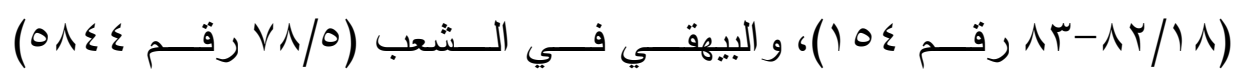

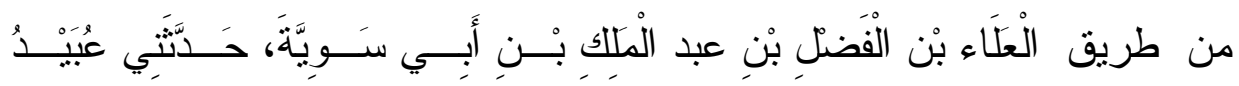

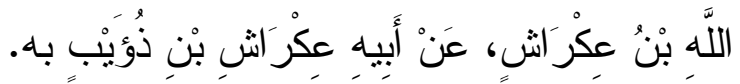

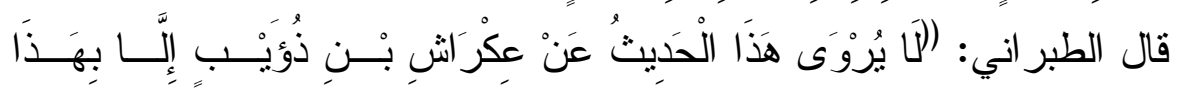

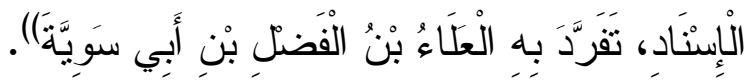

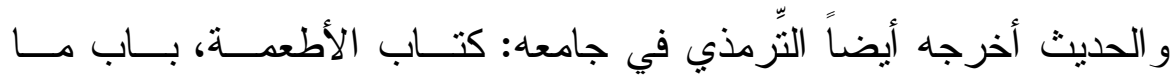

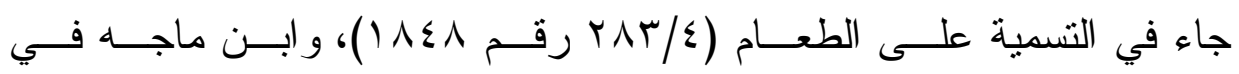

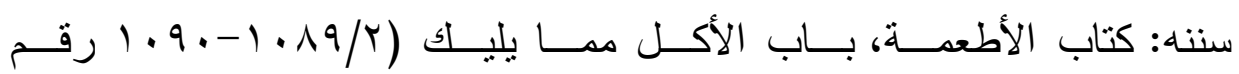
ع (YTV من الطريق نفسها بنحوه، وليس فيه موضع الثـاهد.

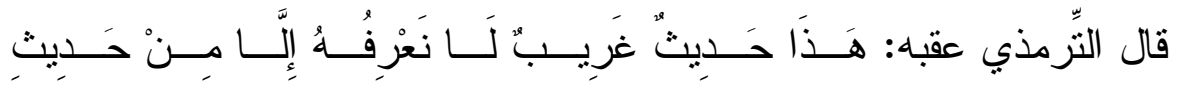

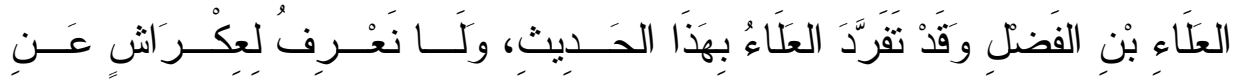
النبّبِيِ

وفي إسناده العلاء بن الفضل هذا، قال ابـن حجــر : ضـــيف. التقريــب . (OrOr) 
وشيخه عبيد الله بن عكر اش نقل الحافظ فيـهـهـ قـــول البُخـــاري: لا يثبــــ

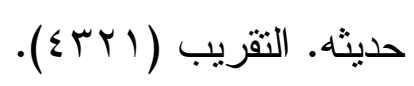

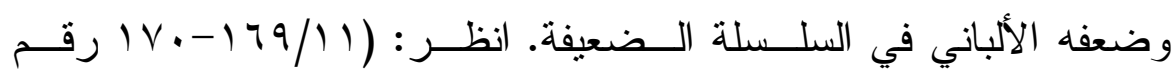

$$
\cdot(0.91
$$

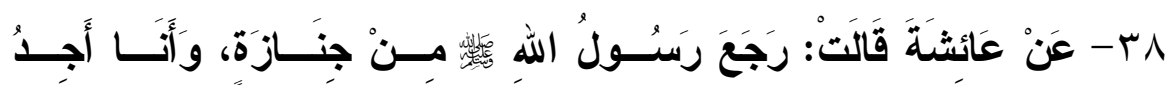

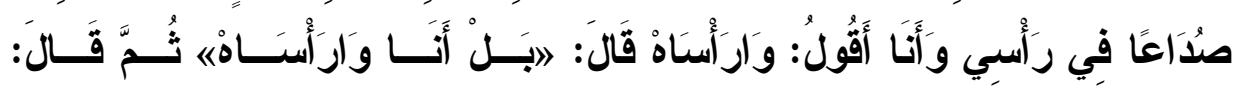

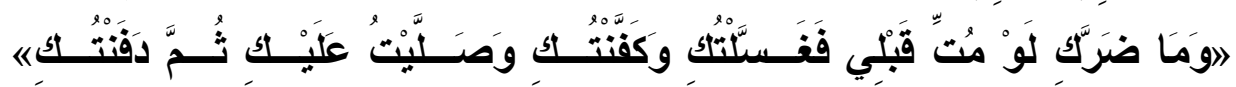

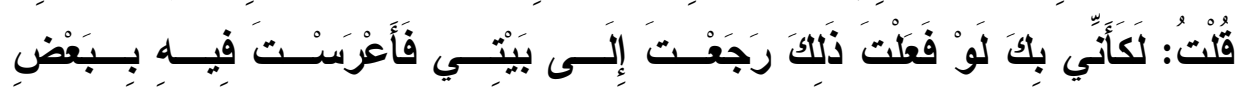

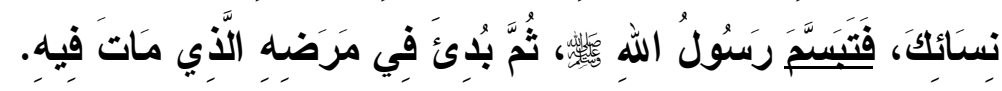

\section{تخريج الحديث:}

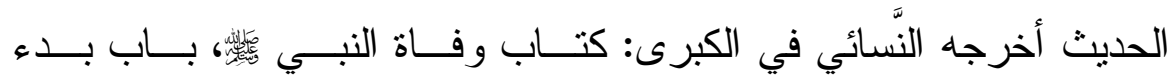

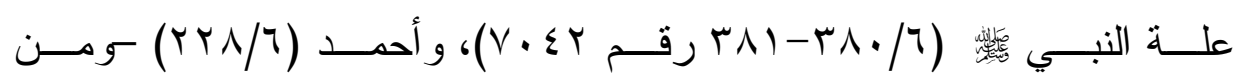

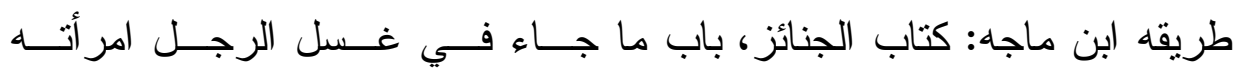

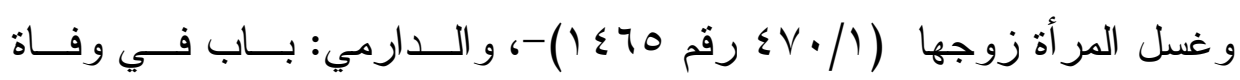

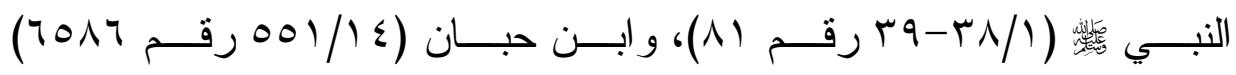
كلهم من طريق محمد بن مسلمة عن محمد بــن إبــحاق عــن يعقـوب بــن ونـ

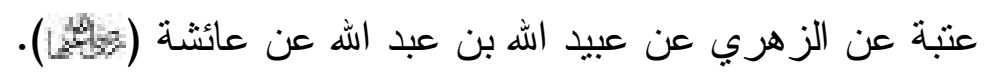

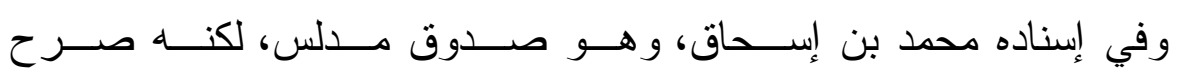

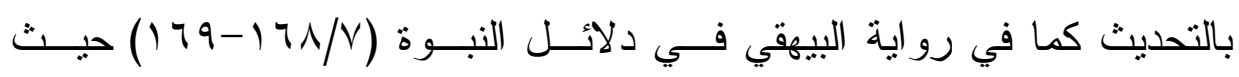

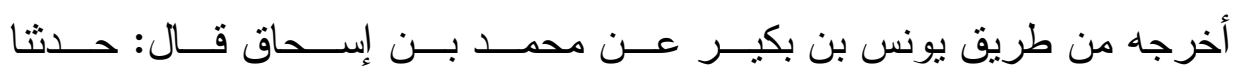
يعقوب بن عتبة به. 


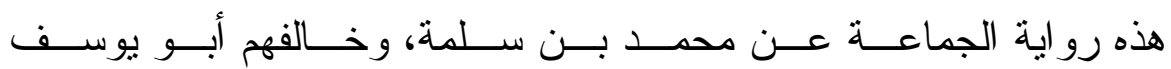

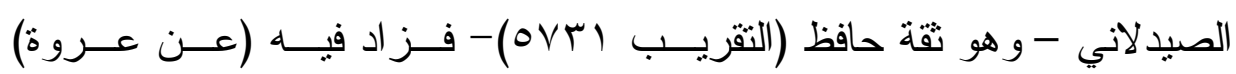

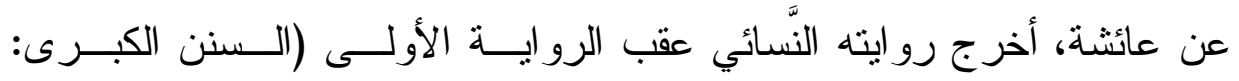
الموضع السابق رقم rی • V).

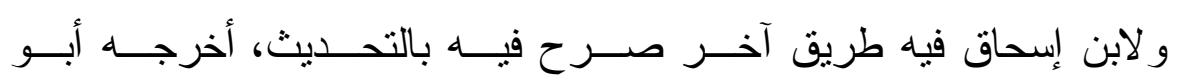

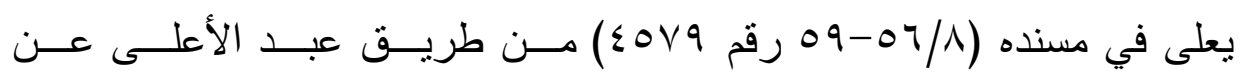

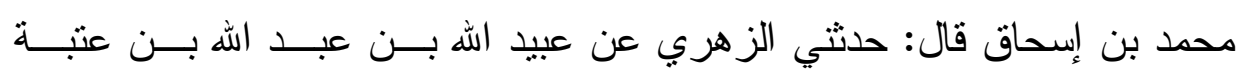
عن عائشة.

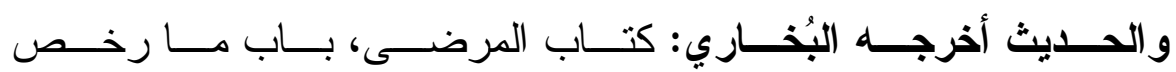

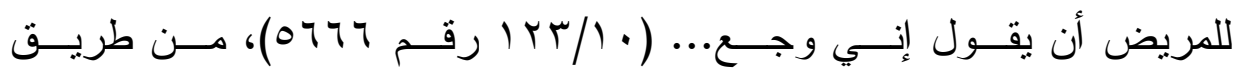

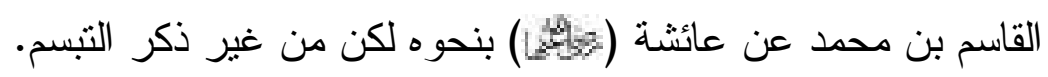

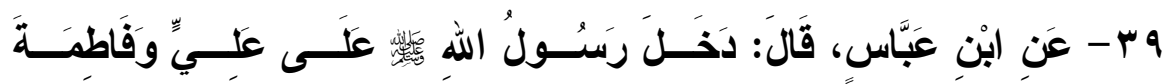

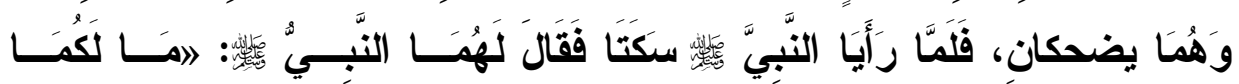

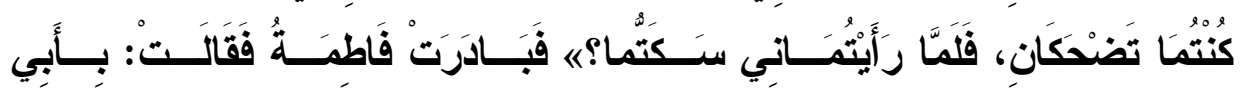

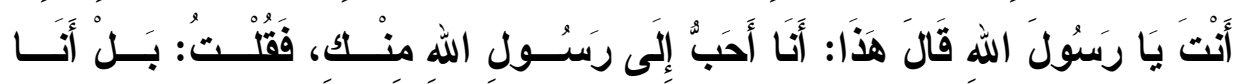
أَحَبٌُ إلَلَى رَسَوْلِ اللَهِ

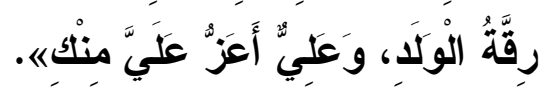

\section{تخريج الحديث:}

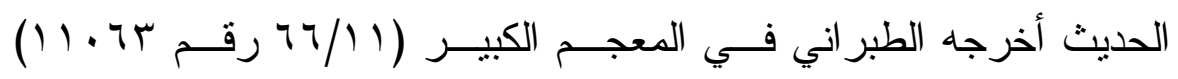

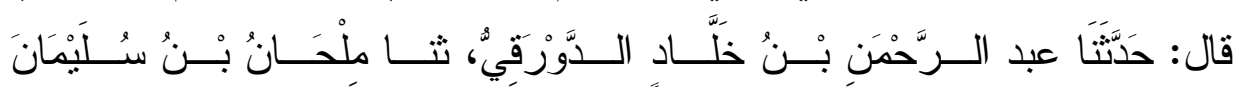




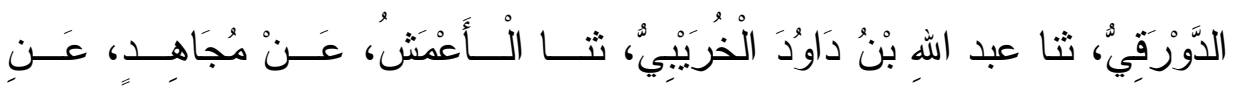
ابَنْ عَبَّاسِ

قــال الهيثـــي: رو اه الطبر انــي، ورجالــهـهـ رجــال الــصحيح. مجمــع

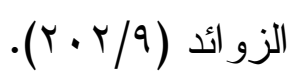

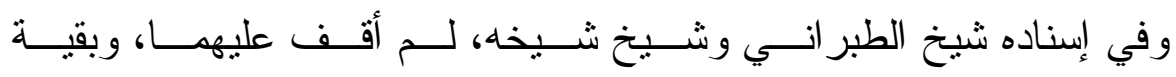
رجاله ثقات.

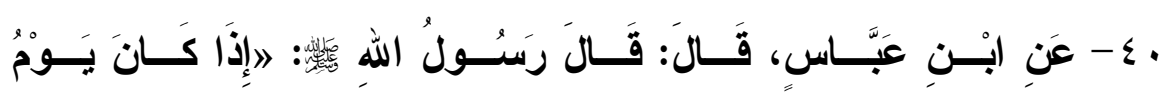

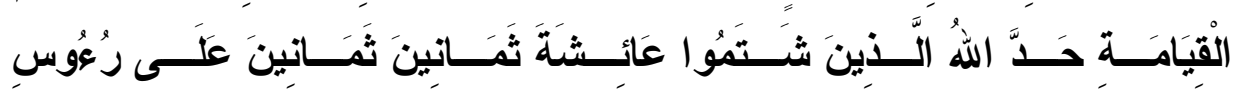

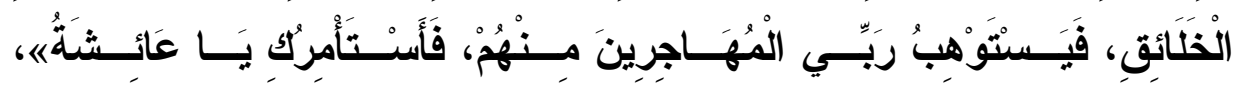

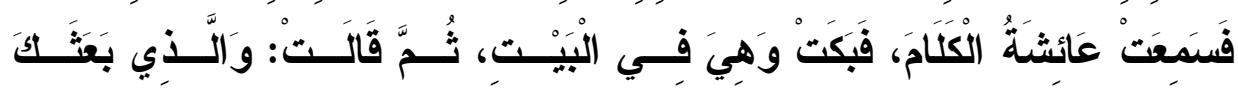

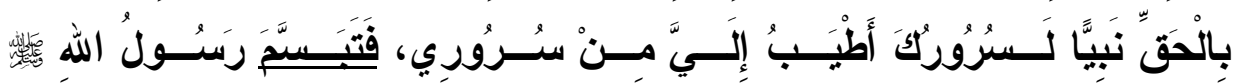

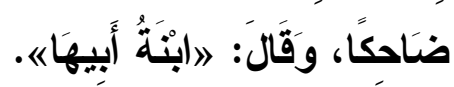

\section{تخريج الحديث:}

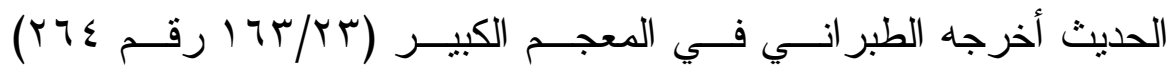

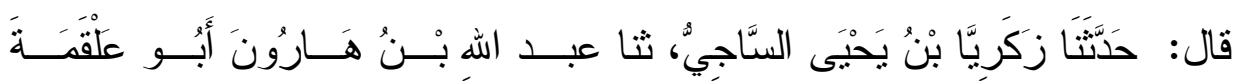

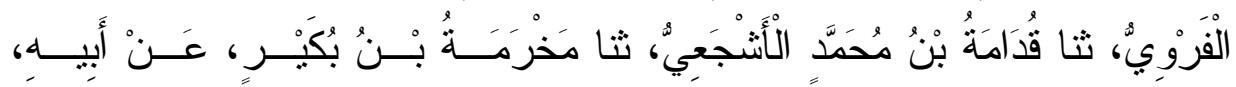
عَنْ ابْنِ شِهَابِ، عَنْ عُبِيْدِ الله بْنِ عبد الله، عَنْ ابْنِ عَبَّاس.

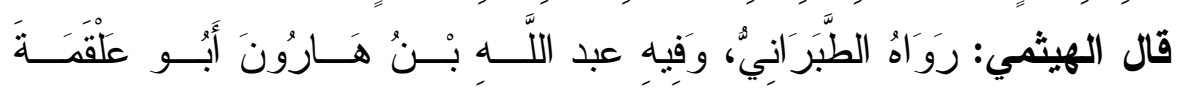

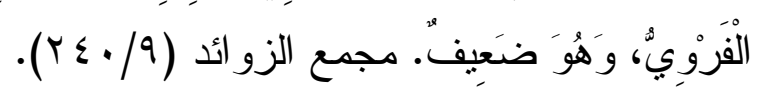

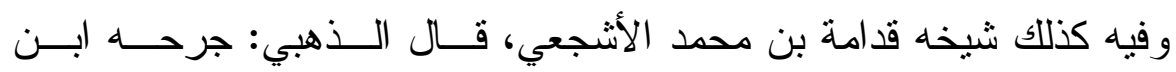

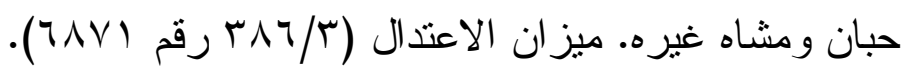




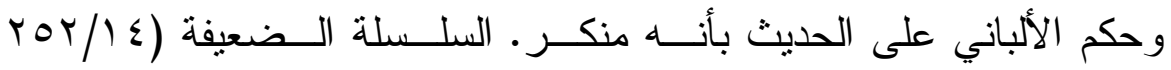

$$
\text { رقم } 0 \text {. (77). }
$$

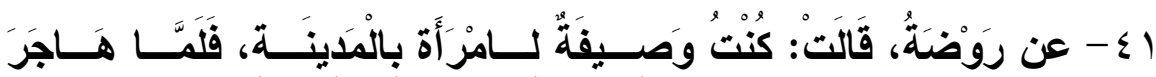

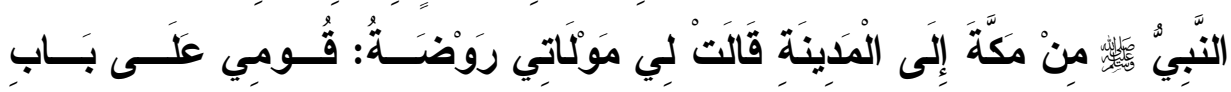

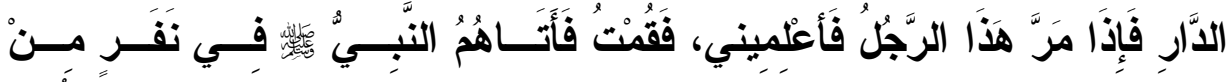

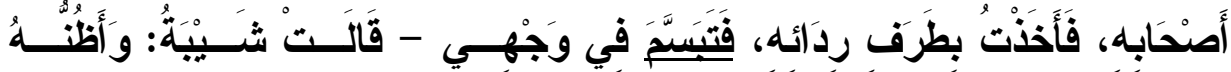

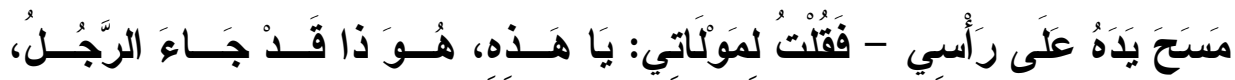

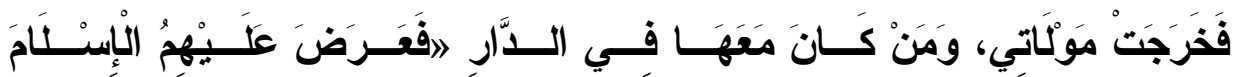

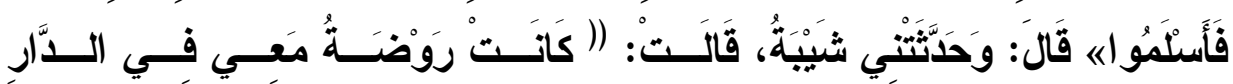

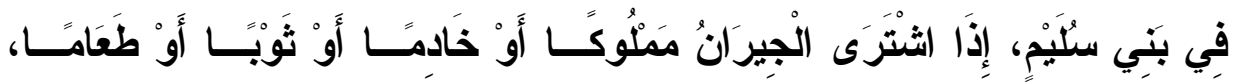

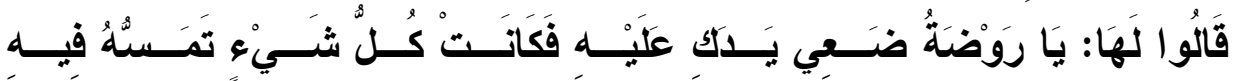
الْبَركَةُة.

\section{تخريج الحديث:}

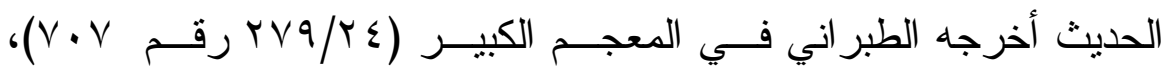

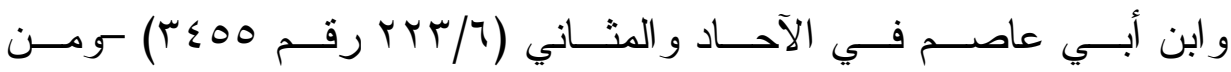

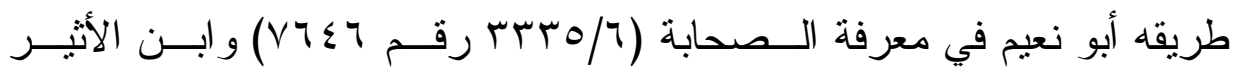

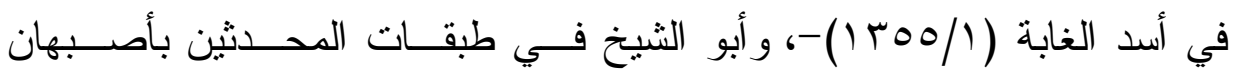

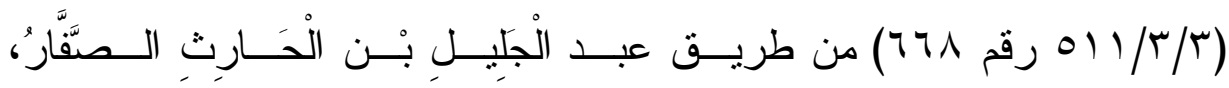

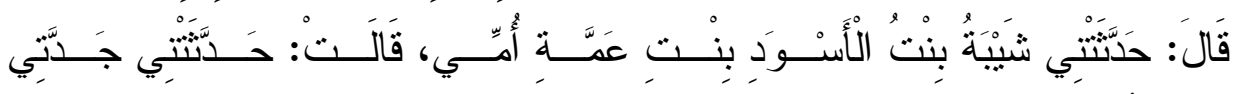




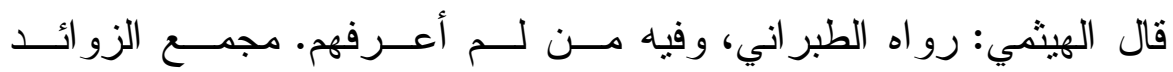
.$(r+r / 9)$

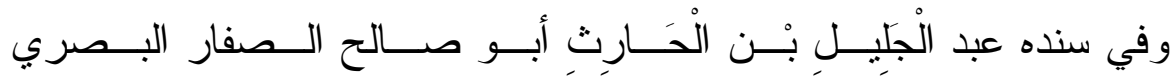

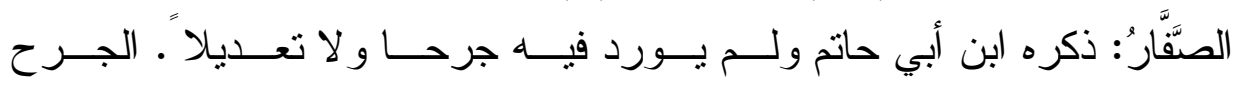

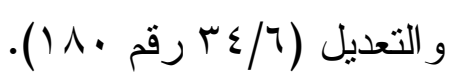

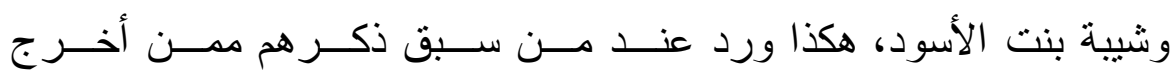

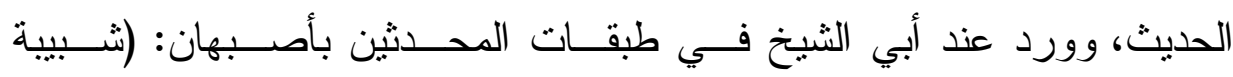
بنت الأسود)، وورد فــي الإصــابة لابــن حجـر (TOV/V): (ثبيتــة)، ولـــ أقف على ترجمتها.

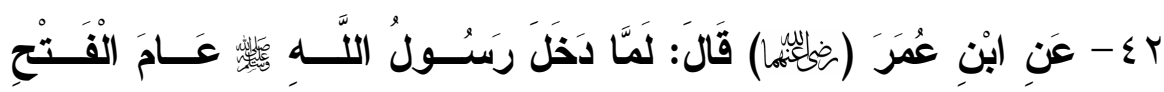

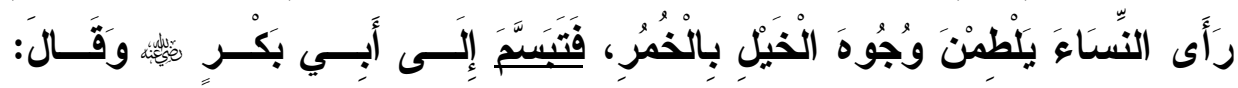

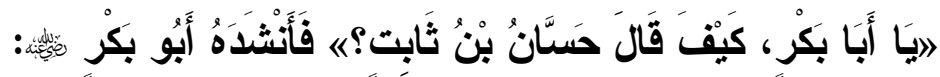

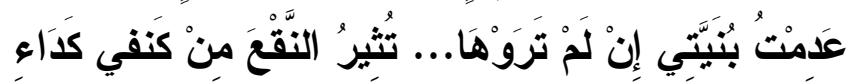

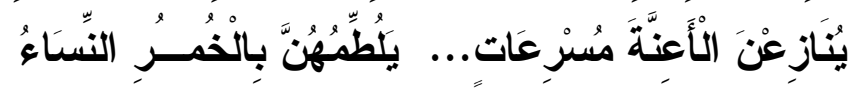

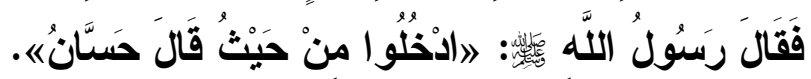

\section{تخريج الحديث:}

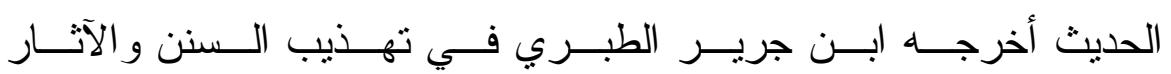
( (

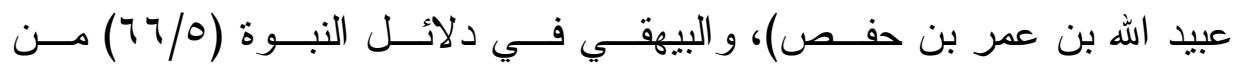

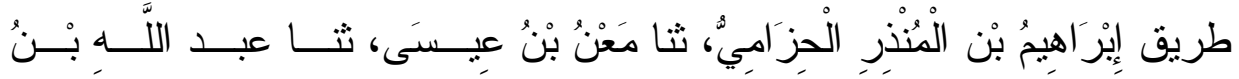

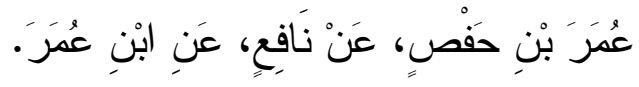




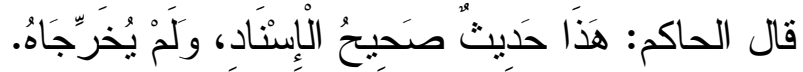

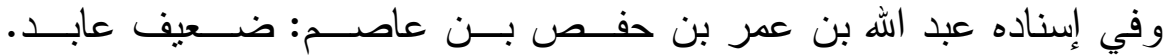

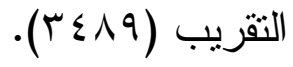

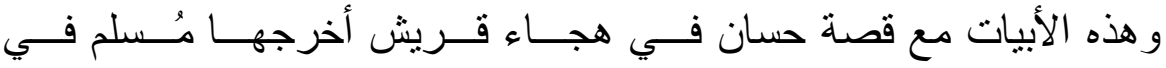

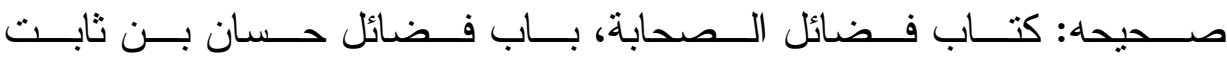

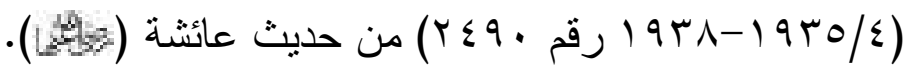

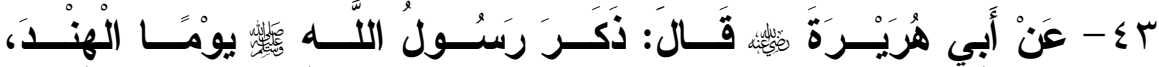

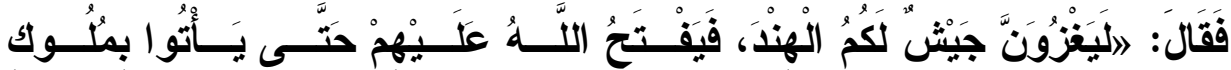

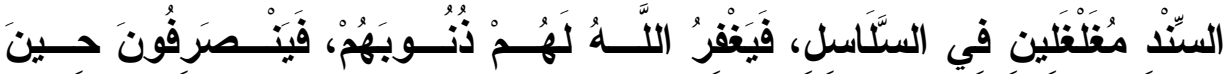

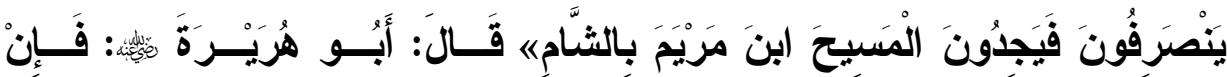

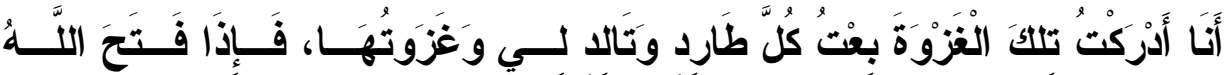

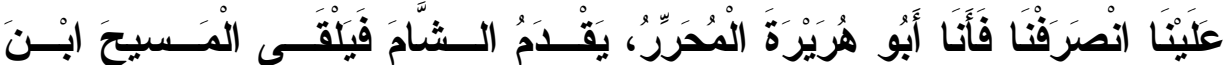

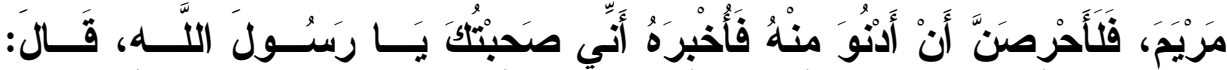

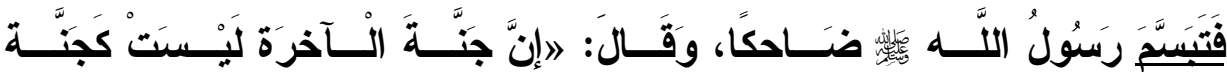

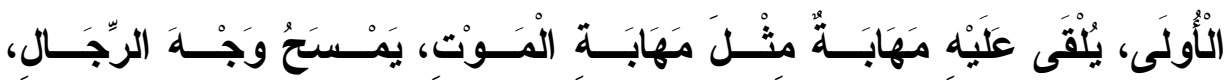

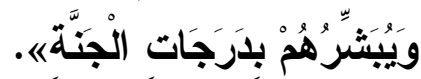

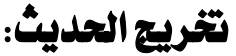

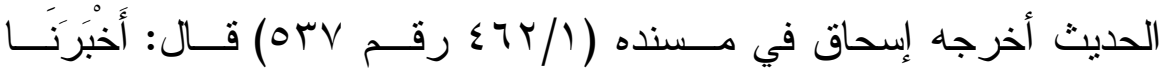

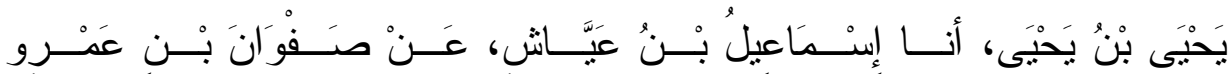

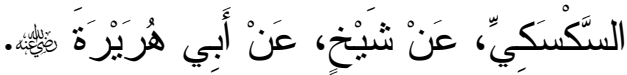
و إسناده ضعيف، فيه رجل مبهه، وهو الر اوي عن أبي هريرة. 


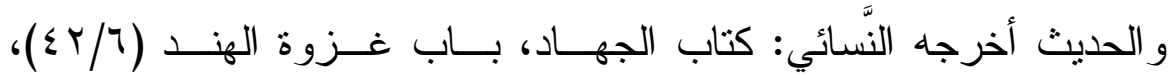

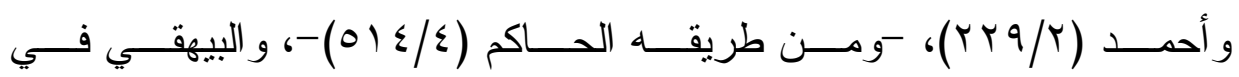

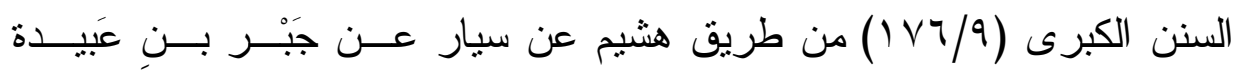

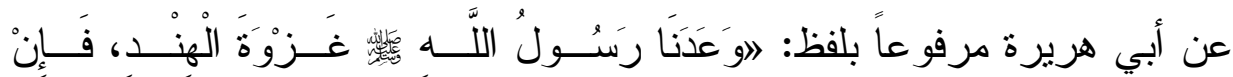

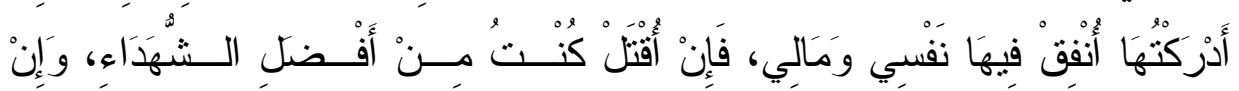

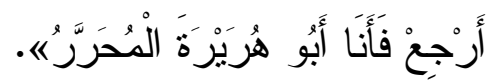

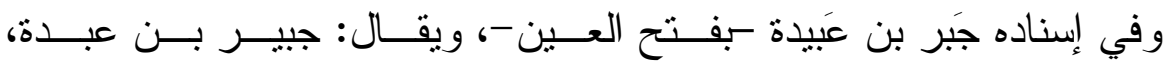

$$
\text { مقبول. التقريب (rqr). }
$$

قال الأهبي: عن أبي هريرة بخبــر منكــر لا يعــرف مــن ذا، وحديثــه:

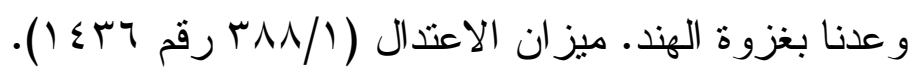

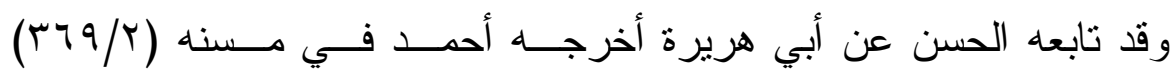

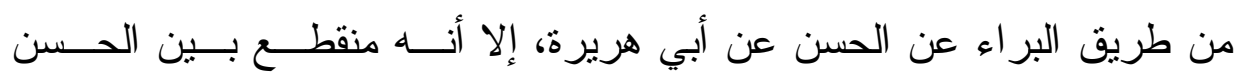

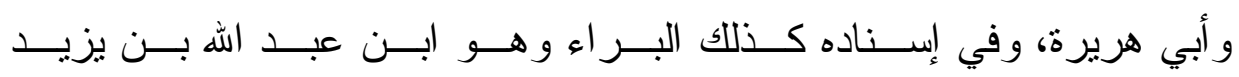

$$
\text { الغنوي، ضعيف. التقريب (9 ( ؟ ؟). }
$$

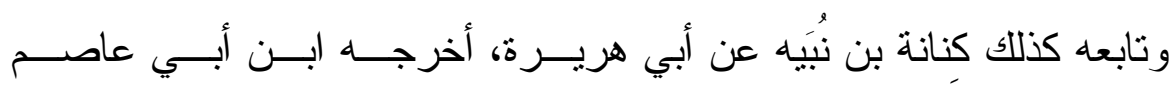

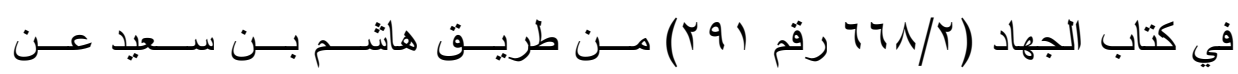
كنانة بن نبييه مولى صفية عن أبي هريرة.

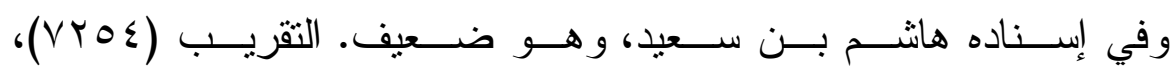
وكنانة قال الحافظ: مقبول، ضعفه الأزدي بلا حجة. التقريب (79 (79ه). و الحديث بمجموع طرقه يتقوى، ويدل على أن له أصلاً، و اله أعلم. 


\section{المبحث الخامس}

الأحاديث الهاردة في تبسم النبي لهب

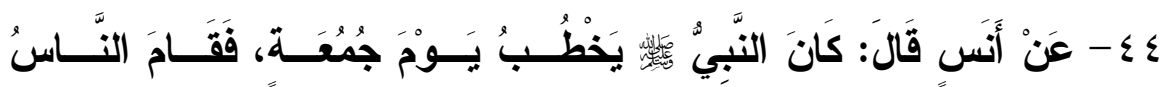

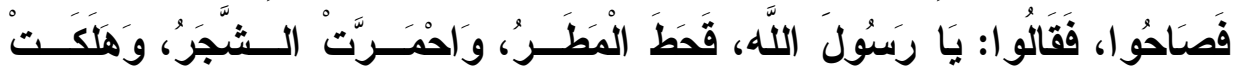

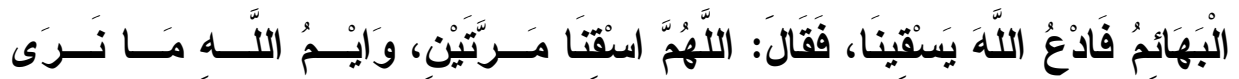

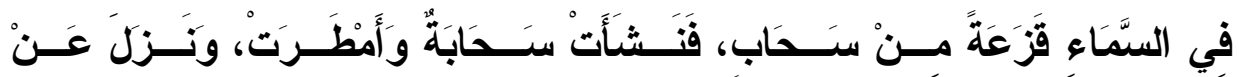

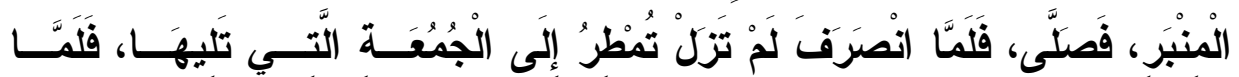

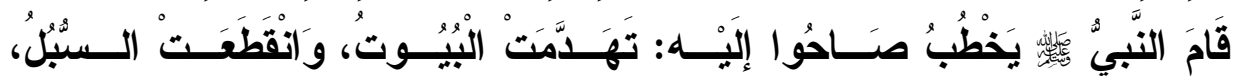

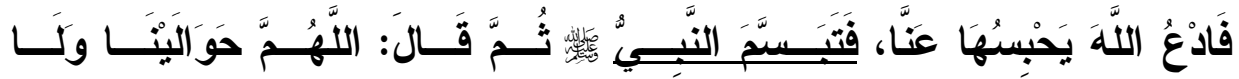

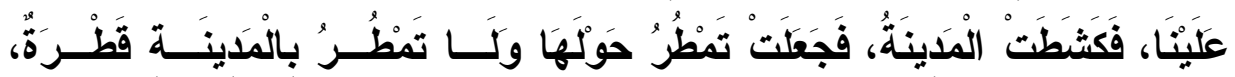

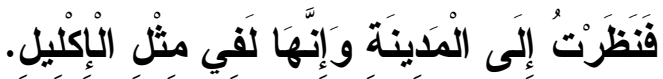

\section{تخريج الحديث:}

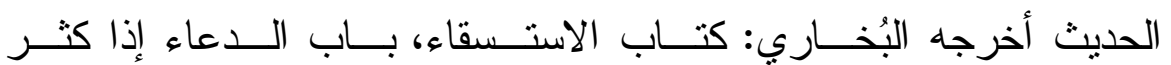

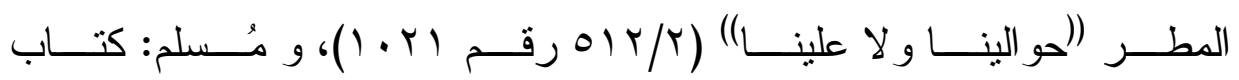

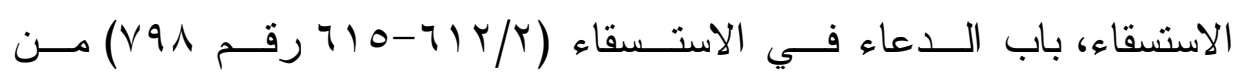
طريق ثابت عن أنس، ومن طرق أخرى عنه نِّئيَ أيضاً.

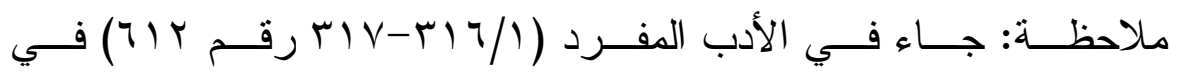

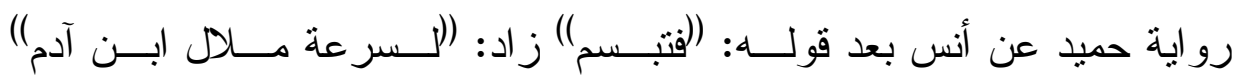
و هو تعليل لابتسامته ئل وانظر: فتح الباري (r/0.0). 


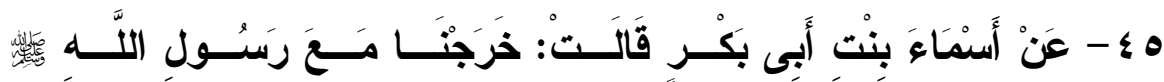

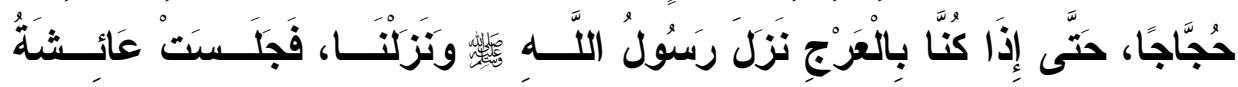

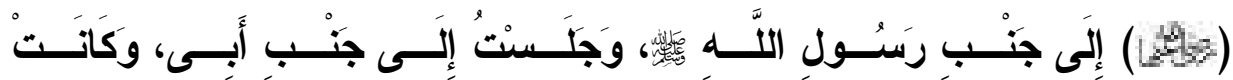

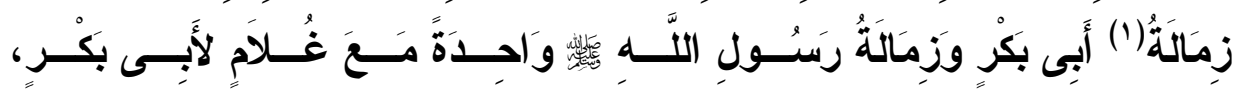

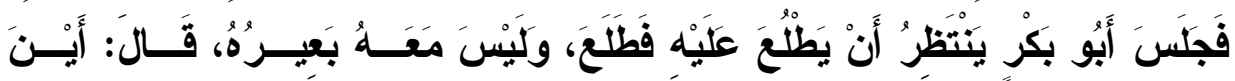

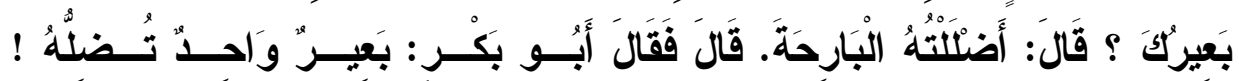

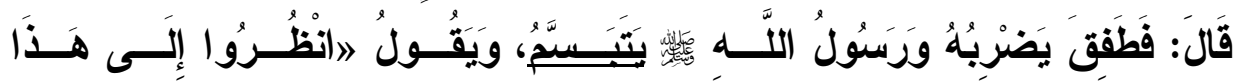

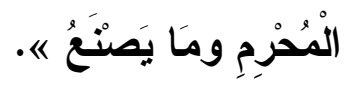

\section{تثريج الحديث:}

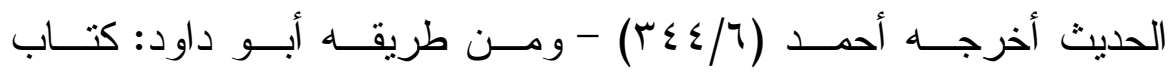

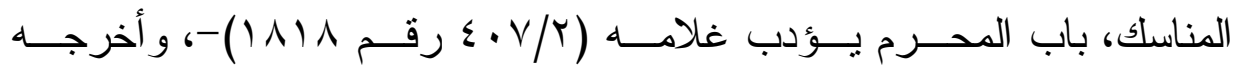

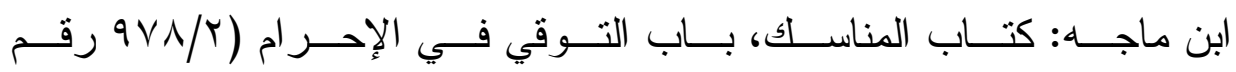

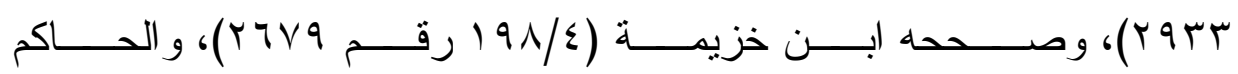

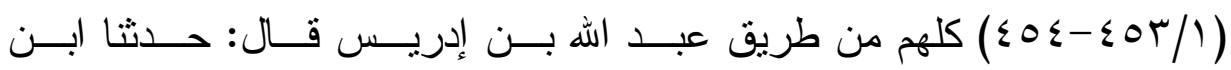

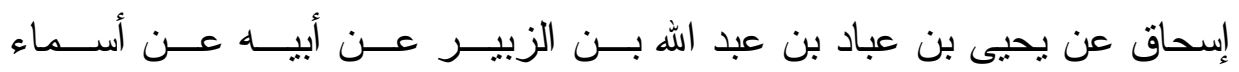
بنت أبي بكر به.

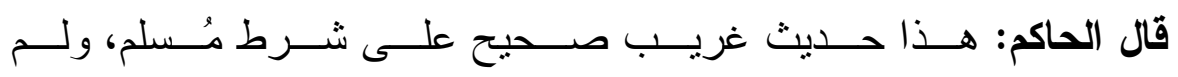
يخرجاه.

ورجاله إسناده ثقات، غير أن فيه عنعنــة ابــن إســحاق، وهـــو مـــلس،

فالإسناد ضعيف.

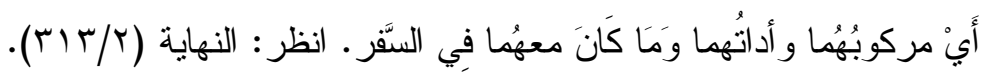




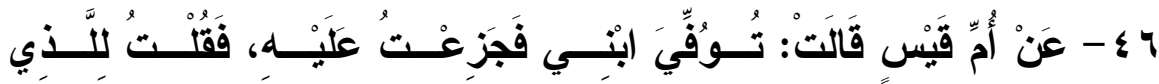

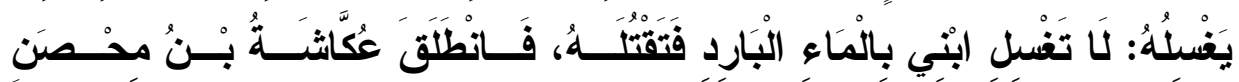

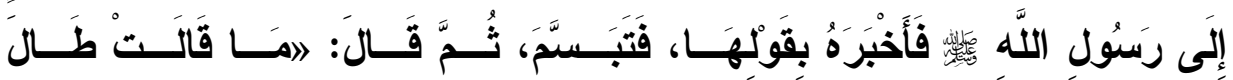

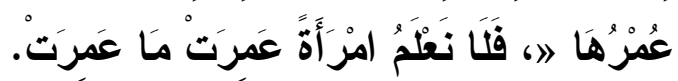

\section{تخريج الحديث:}

الحديث أخرجه النسائي: كتاب الجنــائز ، بــاب غـــل الميــــــــالحميم

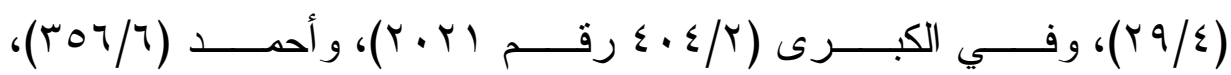

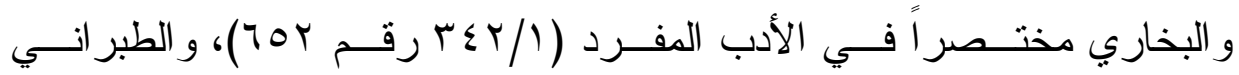

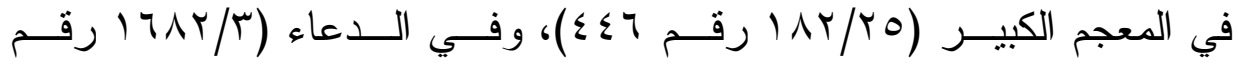

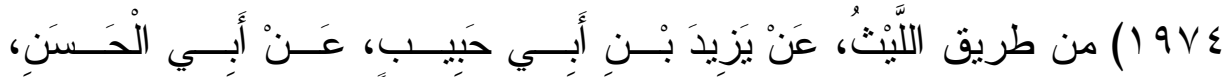

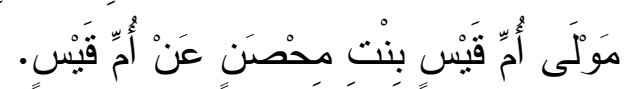

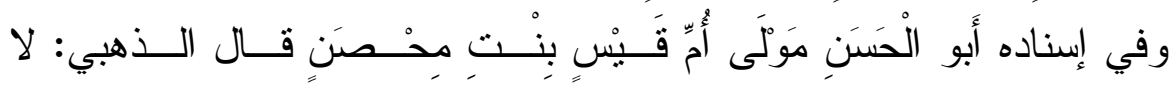

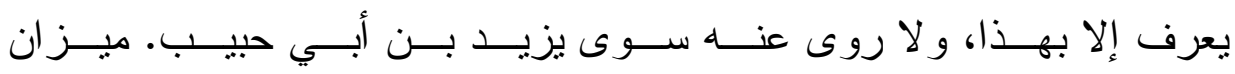

$$
\begin{aligned}
& \text { الاعتدال (ع/0 10 رقم r · 1. 1). } \\
& \text { وقال الحافظ في التقريب: مقبول. }
\end{aligned}
$$

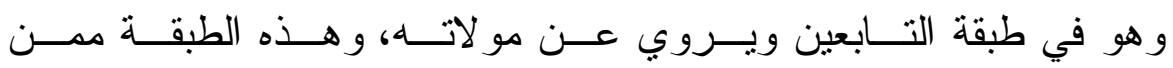

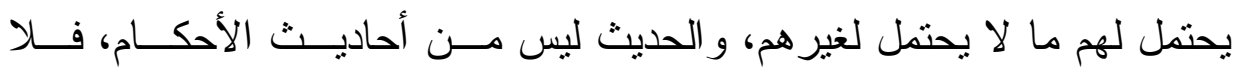
يبعد أن يكون له أصلا، و الله أعلم.

ع V

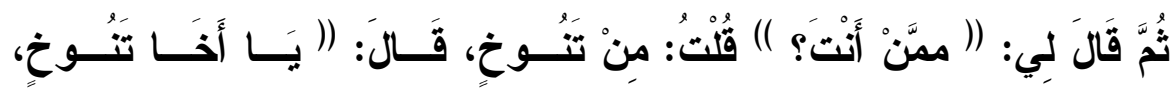

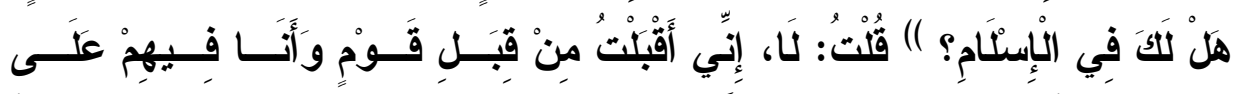

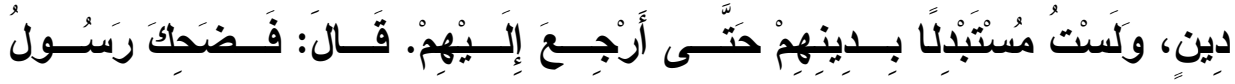




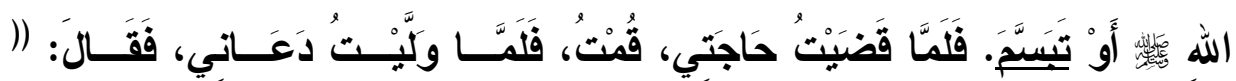

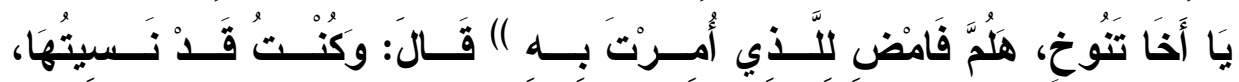

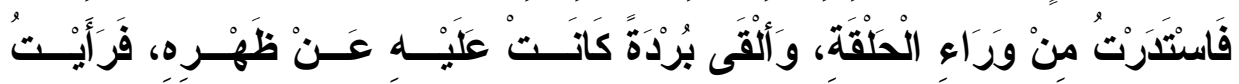

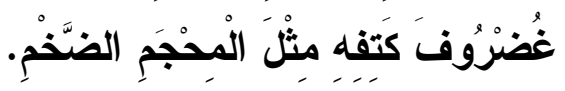

\section{تخريج الحديث:}

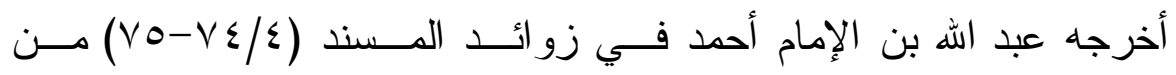

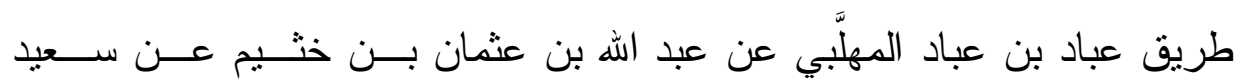
بن أبي راثد عن التتوخي... فذكره.

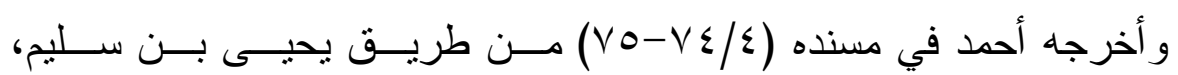

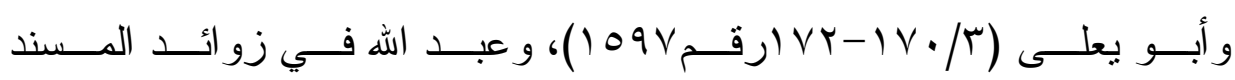

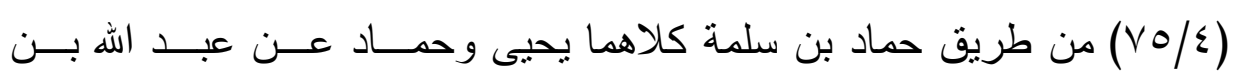

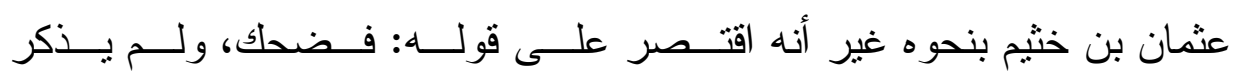

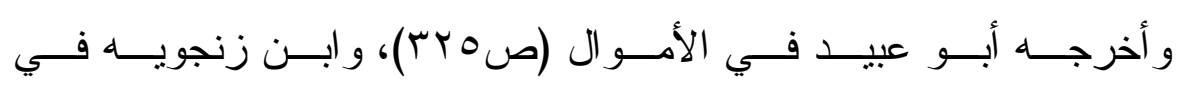

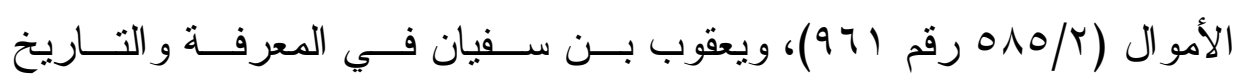
(T/T) سليم مختصر اً من غير ذكر موضع الثاهد.

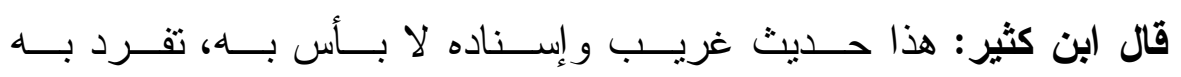
أحمد.البداية و النهاية (1/ ج ( ).

وقال الهيثمي: رواه عبد الله بن أحمد وأبو يعلـى، ورجــال أبــي يعلــى

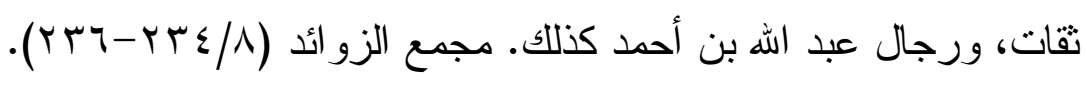




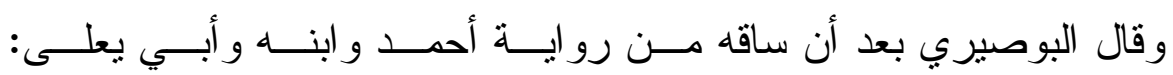
إسناد صحيح.

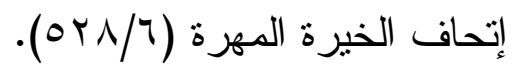
وفي إسناده: سعيد ابن أبي راثد، مقبول. التقريب (1 ـ ب r).

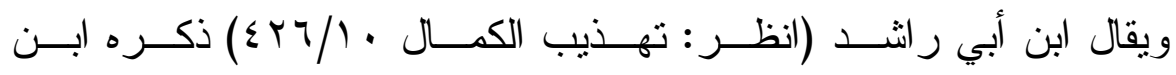

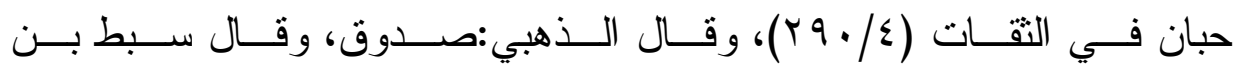

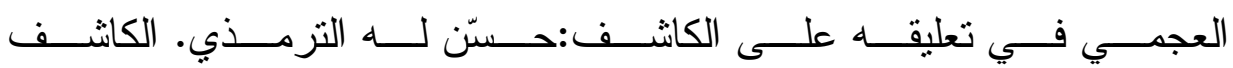

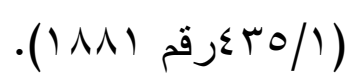

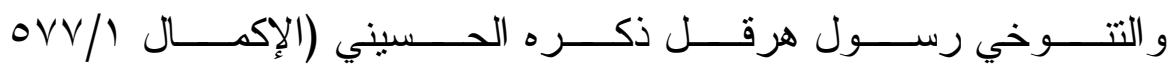

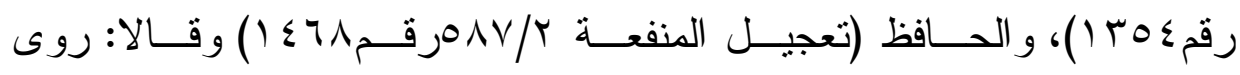
عنه سعيد بن ر اثند.

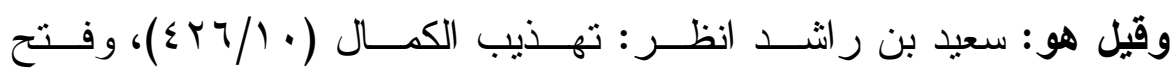

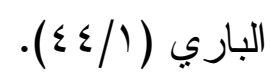
ويذكره علماء المصطلح مثالا لحـديث التـابعي وهـــو موصــول، قـال

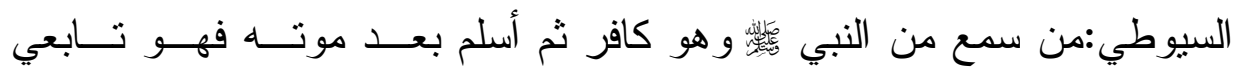

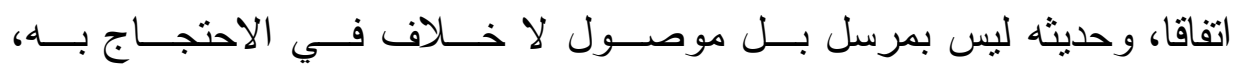

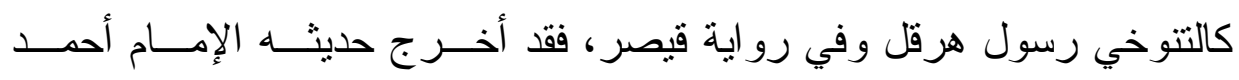

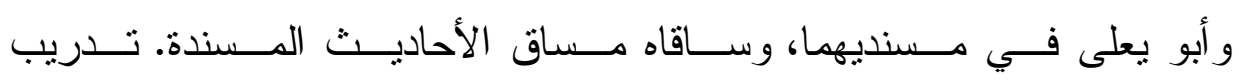

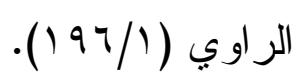

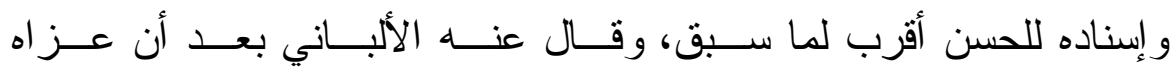

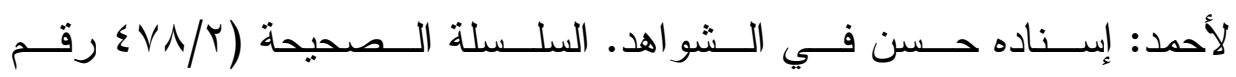




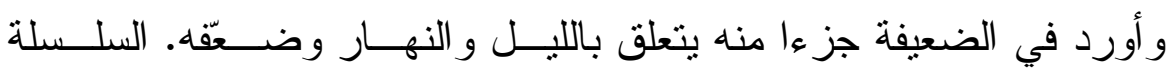

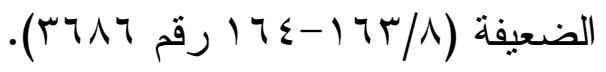

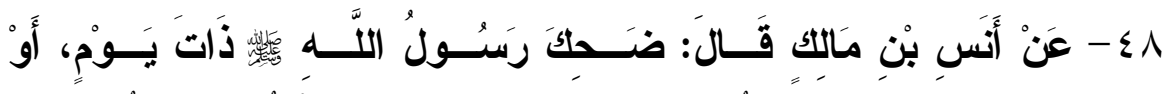

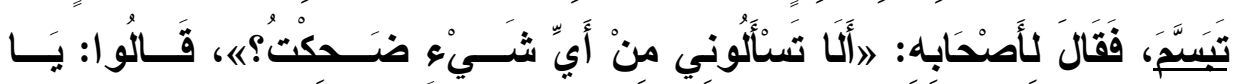

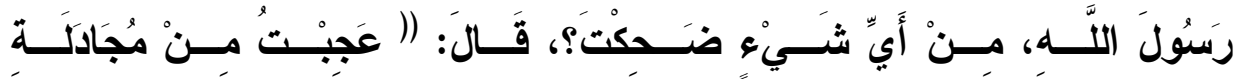

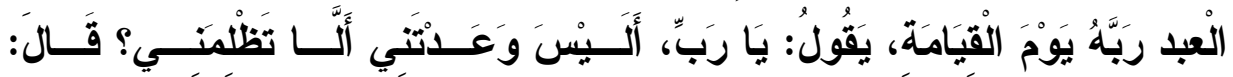

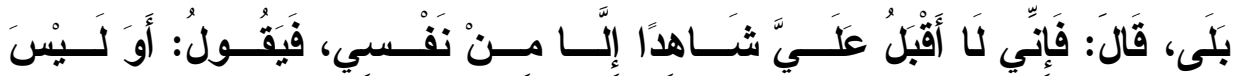

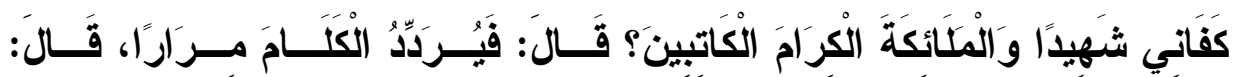

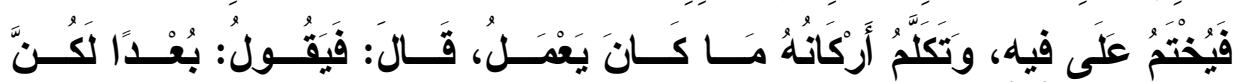

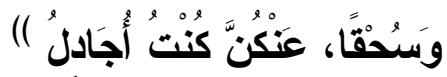

\section{تخريج الحديث:}

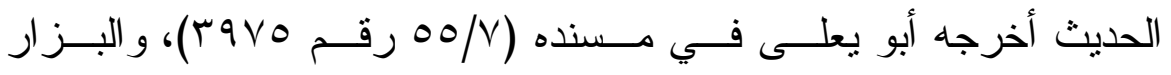

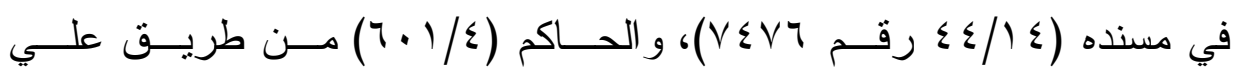

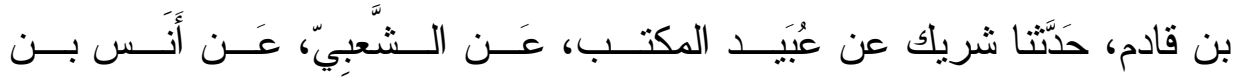
ماللك.

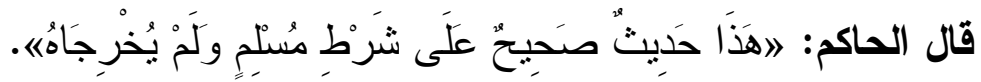

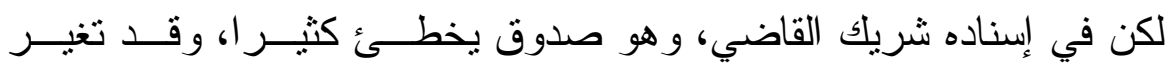
حفظه منذ ولي القضاء. التقريب (rVAV).

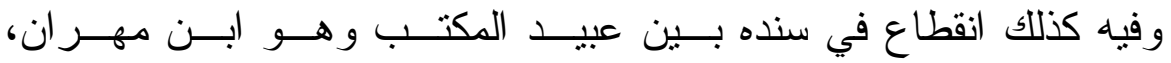

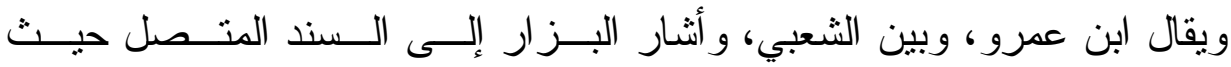




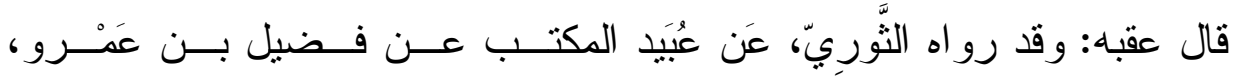

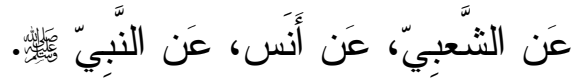
وسئل أبو زرعة عن الحديث برواية شــريك وبروايــة سـفيان الثــوري

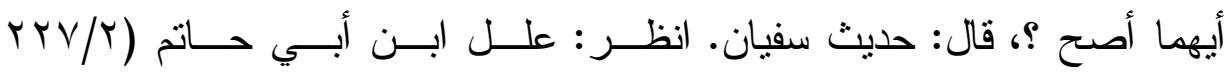

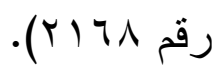

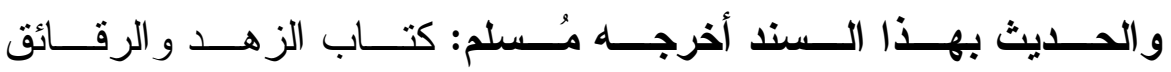

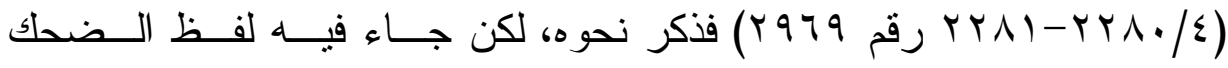
فقط.

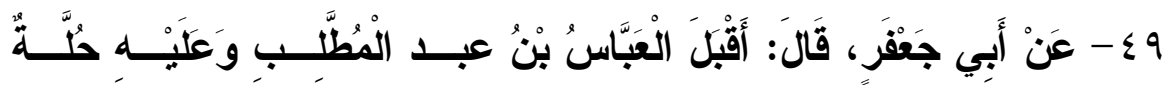

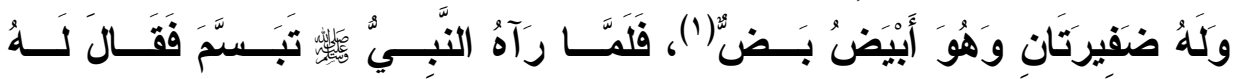

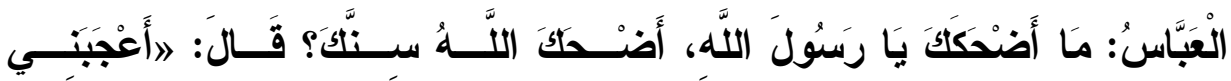

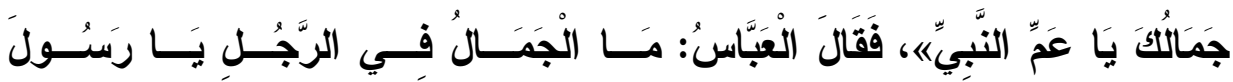

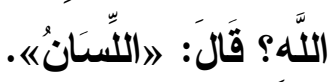

\section{تخريج الحديث:}

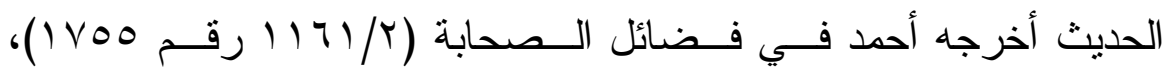

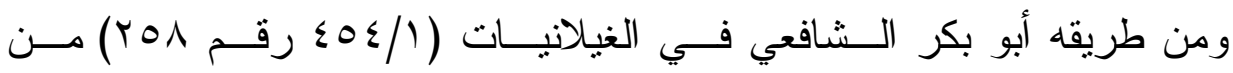
طريق الحكم بن المنذر عن عمر بن بشر الختعمي عن أبي جعفر .

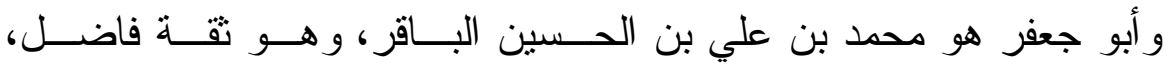
من الر ابعة. التقريب (107 (1) و وعليه فالإسناد منقطع أو معضل.

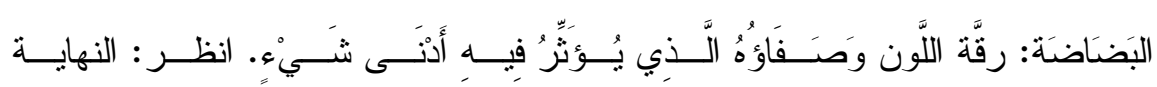

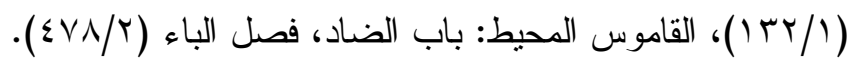


وفيه عمر بن بشر و الحكم بن المنذر لم أقــف علــى ترجمتهــــا. وقـــال

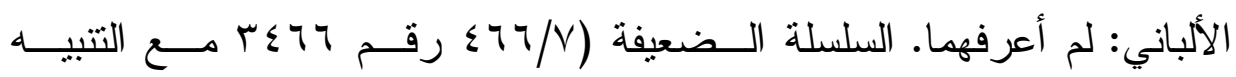

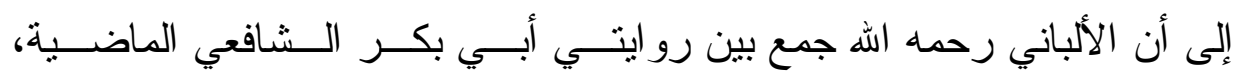
ورو اية الحاكم التالية وهي مختلفة السياق كما سيأني).

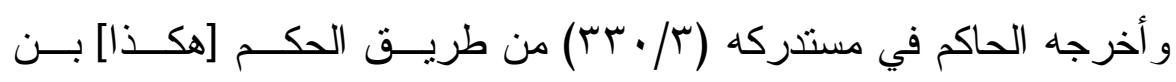

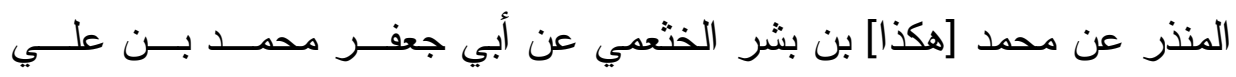
بن الحسين عن أبيه. فز اد قوله: عن أبيه.

قال الذهبي في التلخيص: مرسل.

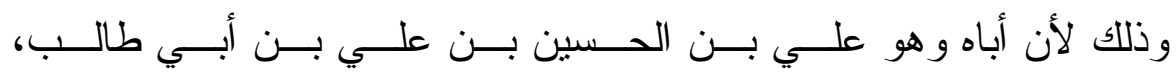
المعروف بزين العابدين، من الثالثة. التقريب (OV (O).

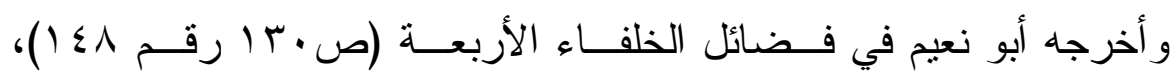

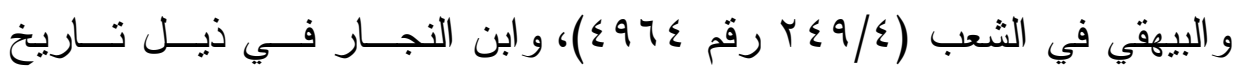

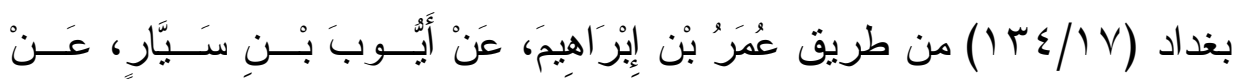

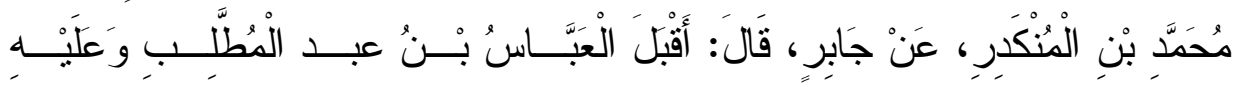

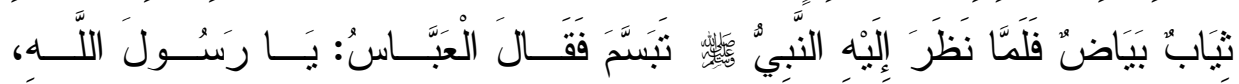

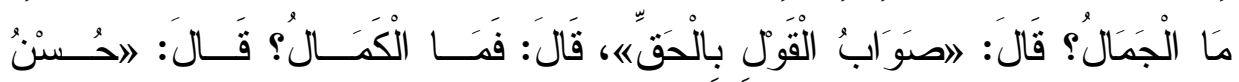
الْفَعَال بالصِّدقق

قال البيهقي عقبه: تقرد به عمر بن إير اهيخ، وليس بالقوي.

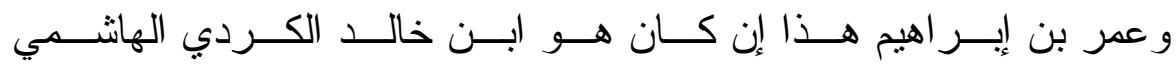
مو لاهم، فقد قال فيه الدارقطني: كذاب خبيث، وقال الخطيب: غير ثقة.

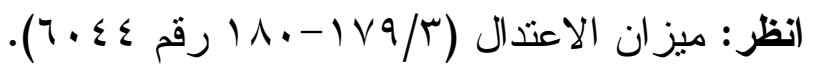




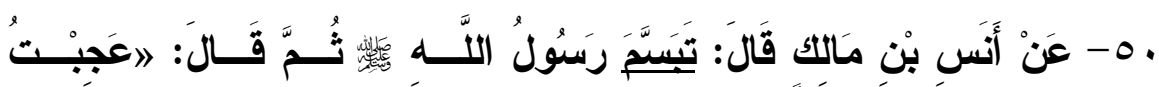

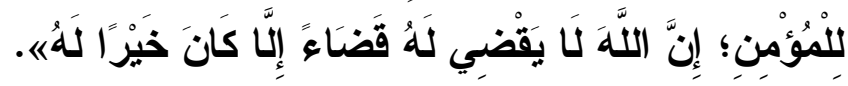

\section{تخريج الحديث:}

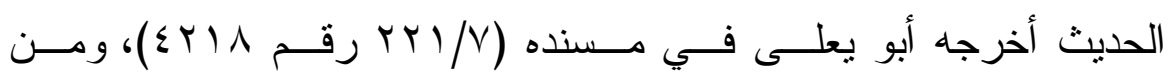

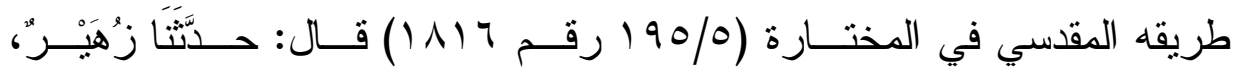

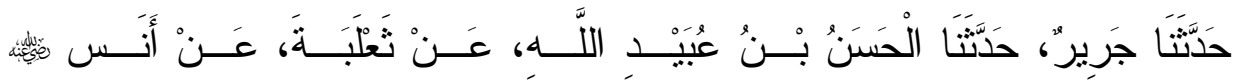
فذكر ه.

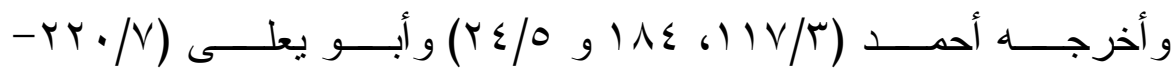

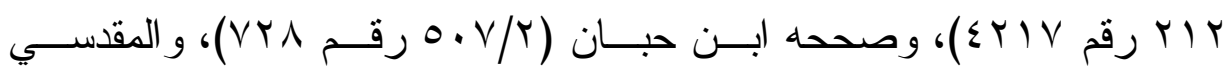

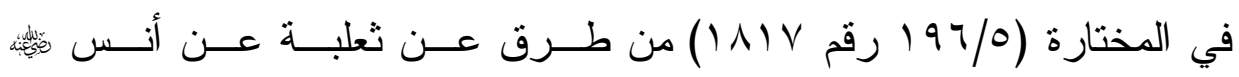
نحوه، وليس فيه موضع الثاهد منه.

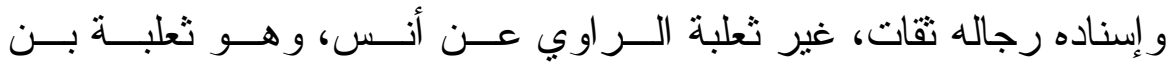

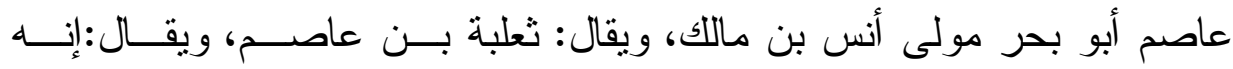

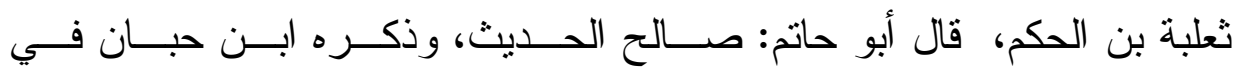
الثقات.

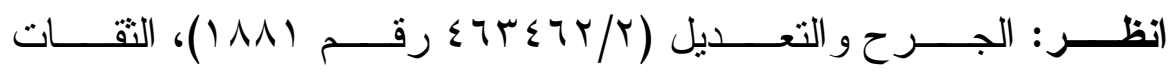

قال الهيثي: رجال أحمد ثقات، وأحد أسانيد أبــي يعلـى رجالــهـ رجـال

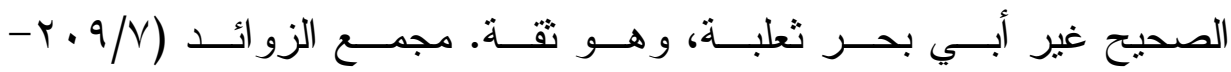
$\cdot(r)$.

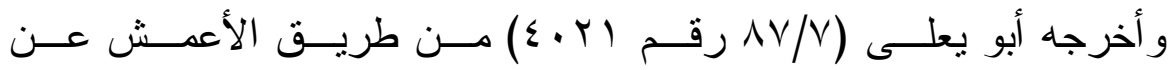

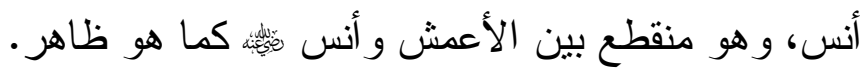




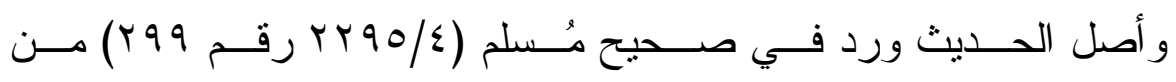
حديث صهيب بنحوه.

1

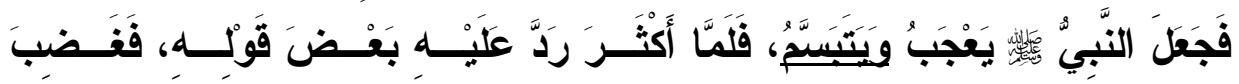

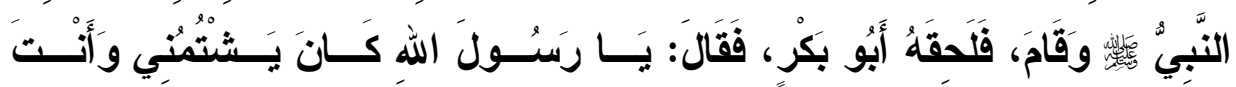

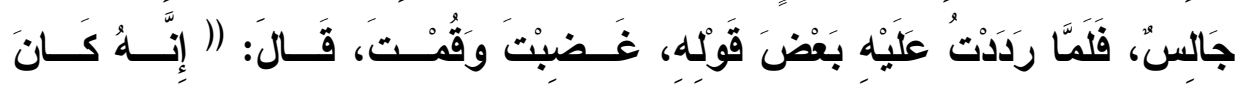

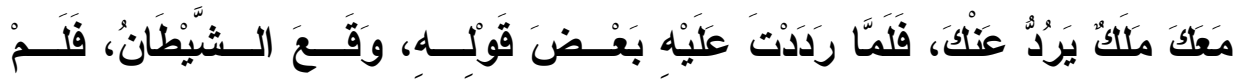

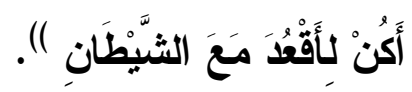

\section{تخريج الحديث:}

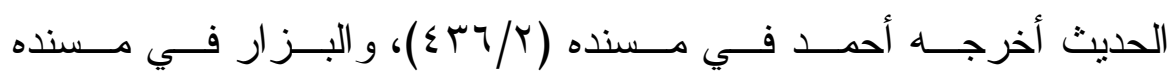

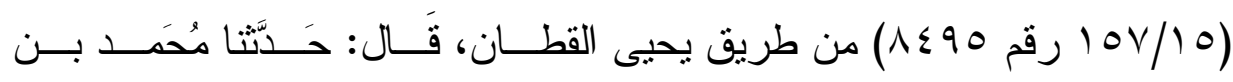
عَجْلان، عَن سَعِيد المقبري، عَن أبي هُرَيَرة.

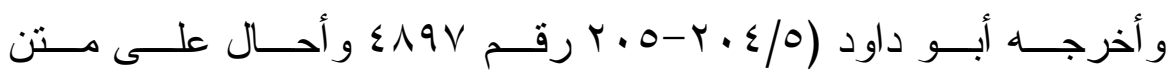

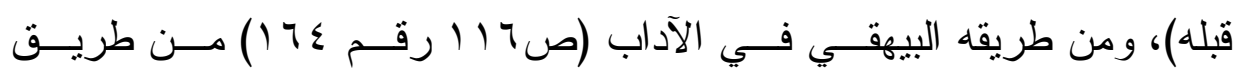
سفيان بن عيينة عن محمد بن عجلان به.

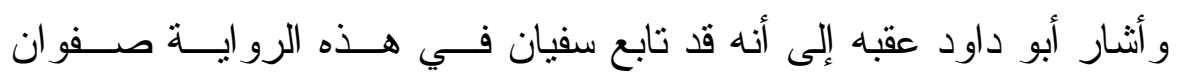
بن عيسى.

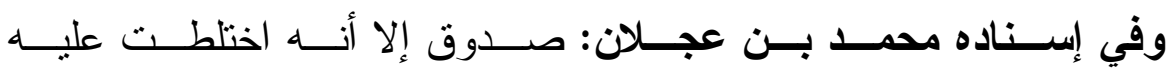

$$
\text { أحاديث أبي هريرة. التقريب (Tس آب). }
$$

وقد خالفه الليث بن سعد فرو اه عـن ســعيد المقبـري عـن بـشير بـن المحرر عن سعيد بن المسيب مرسلا: 


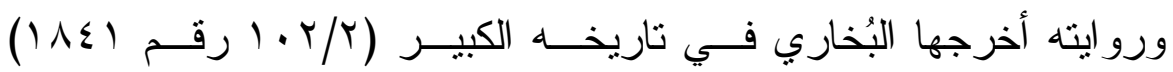

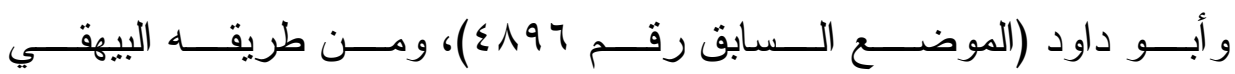

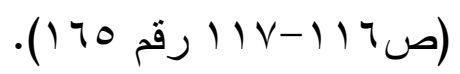

و الليث بن سعد الفهمــي المــصري: ثقــة ثبــت فقيــهـ إمـام مــشهور.

$$
\text { التقريب (or^乏). }
$$

وهو أصح الناس رواية عــن المقبـري، كمـــا ذكــر يحيــى بــن معــين و أحمد بن حنيل. انظر : علل الدر اقطني (A/

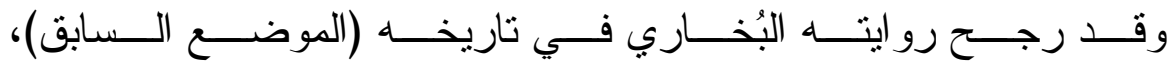

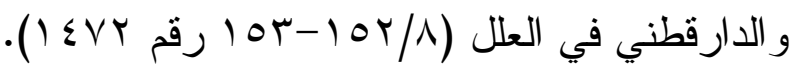

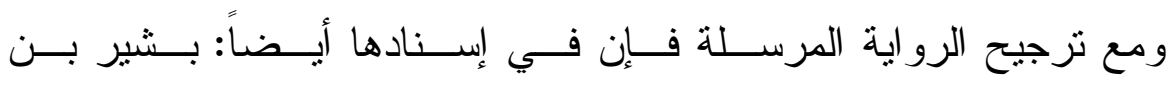

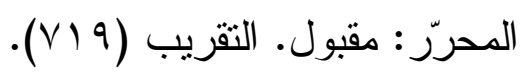

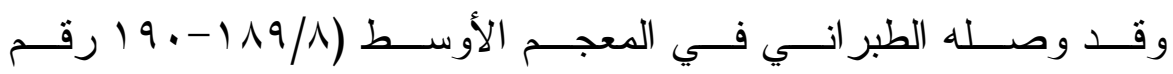

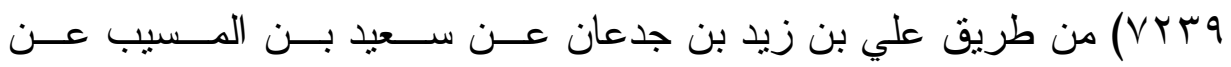

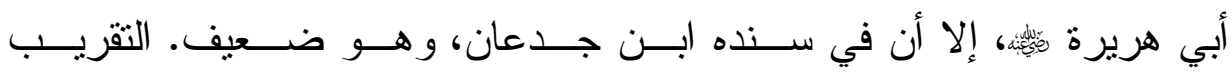
. ( $\varepsilon \vee T \varepsilon)$

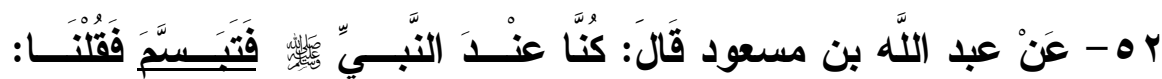

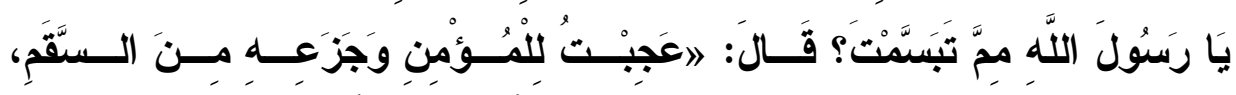

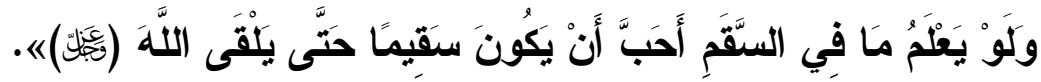

\section{تخريج الحديث:}

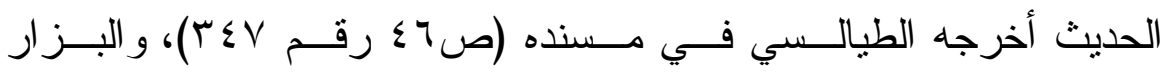

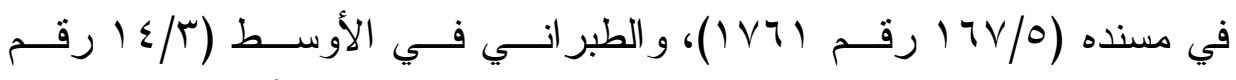

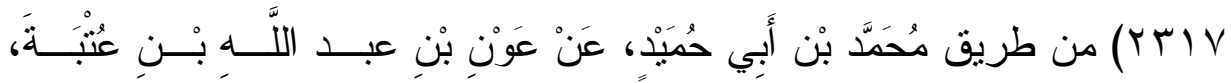




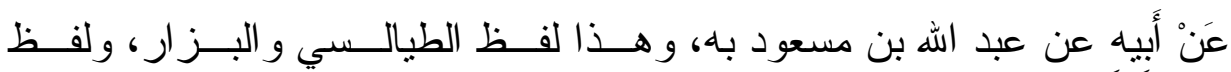
الطبر اني بنحوه و فيه زيادة.

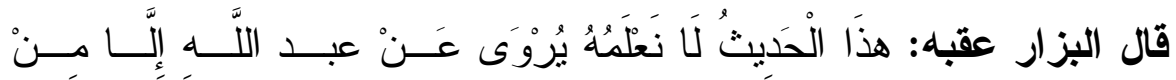
هَذَا الْوَجْهُ.

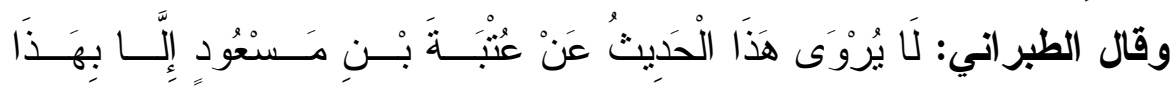

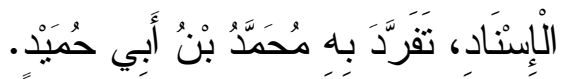
وفي إسناده محمد بن أبي حميد هـــا، قــال الهيثـــي: رواه الطبر انــي

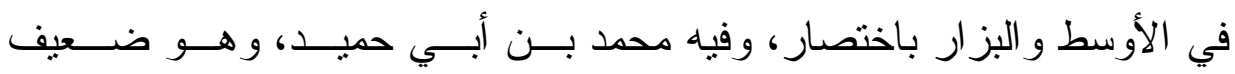
جدا. مجمع الزوائد (ب/؟ • بـ).

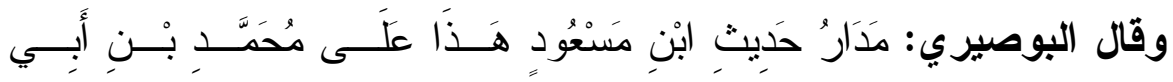

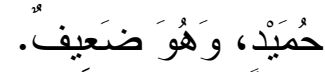

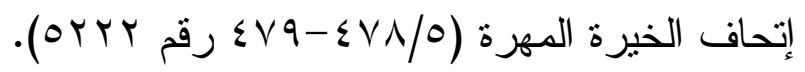

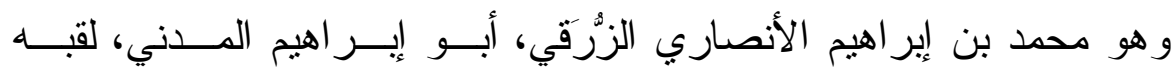
حماد، ضعيف. التقريب (بrمه).

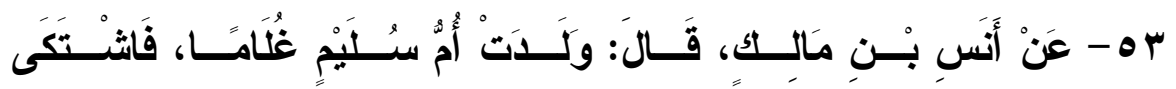

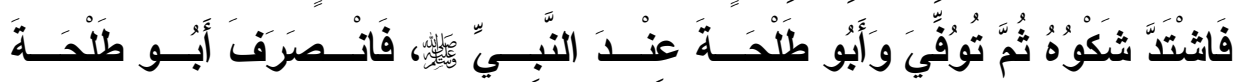

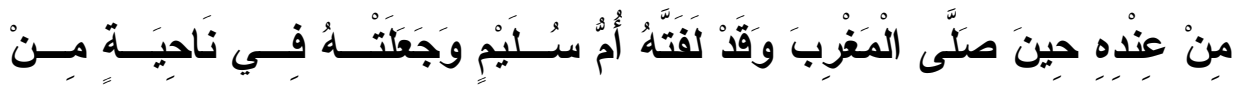

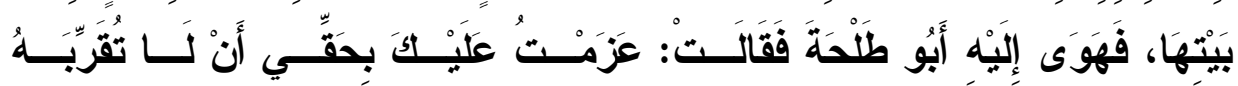

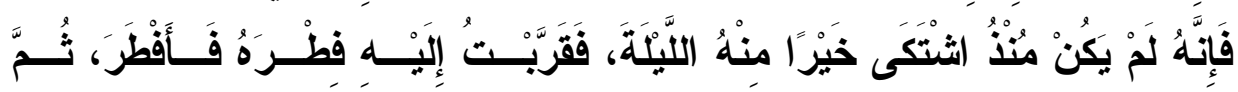

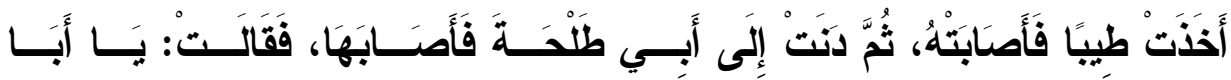

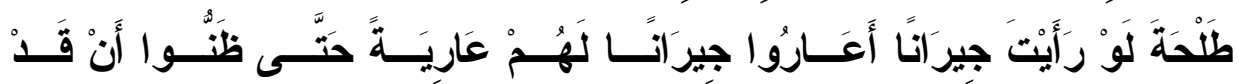




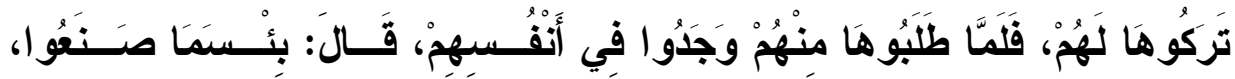

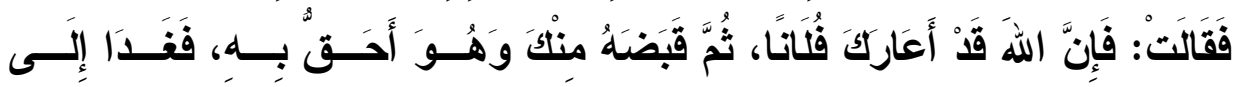
النَّبَِِ

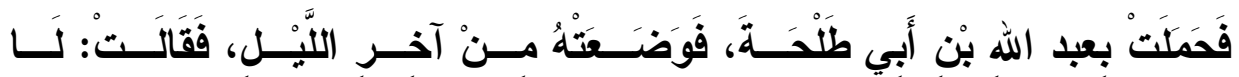

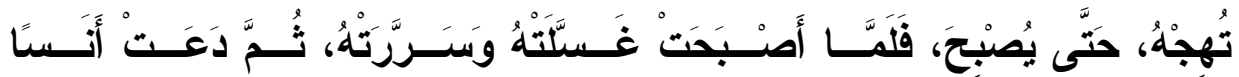

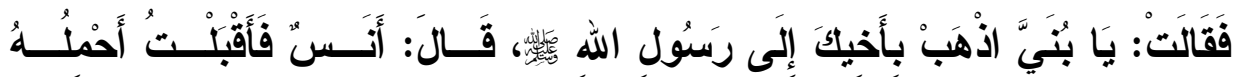

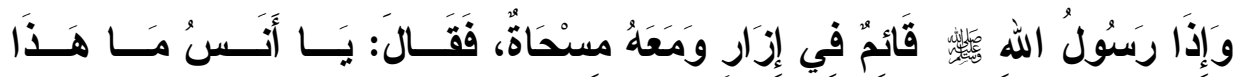

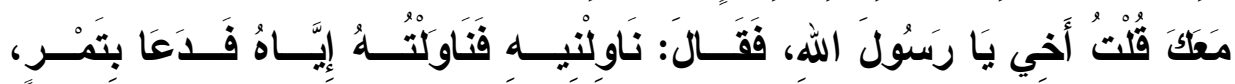

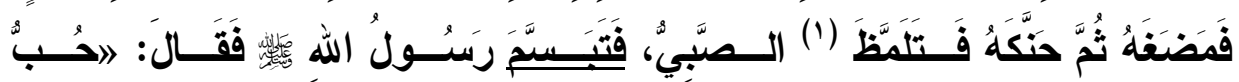

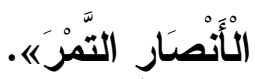

\section{تخريج الحديث:}

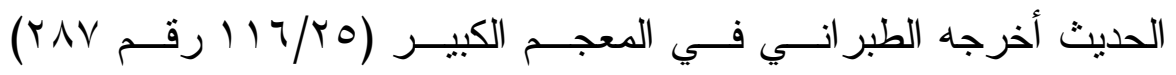

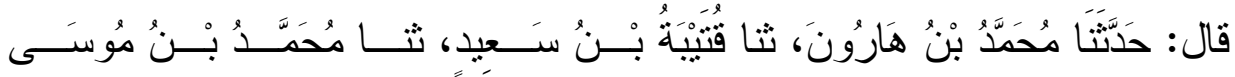

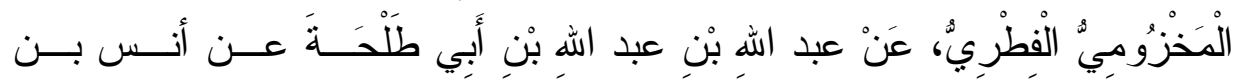
مالك.

و الحديث أخرجه الثيخان في صحيحيهما من طــرق عـن أنـس بنحـــوه غير أنه لم يرد فيه حكاية التبسم. انظر: صحيح البُخاري: كتاب الزكاة، بــاب وســم الإمـــام إبــل الـــدقة

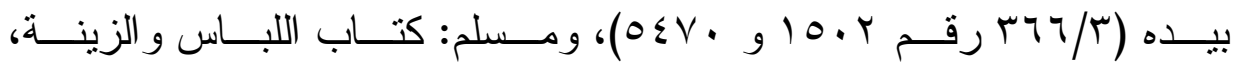

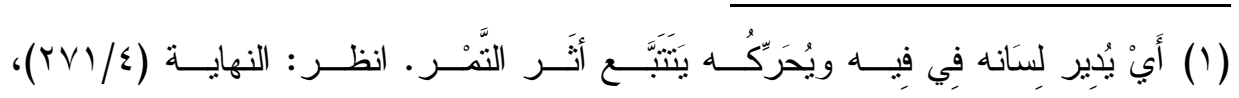

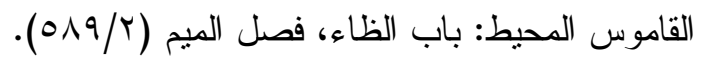




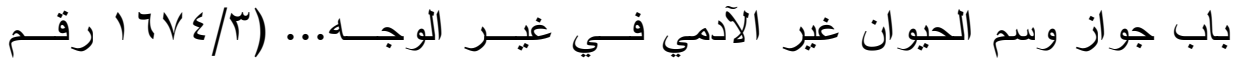

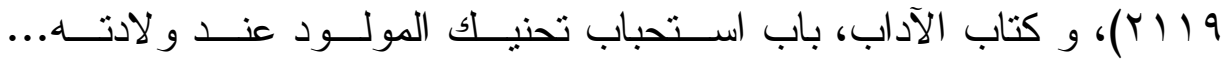

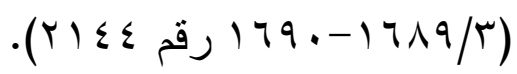

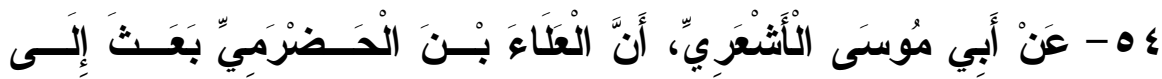

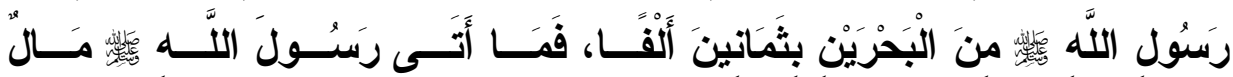

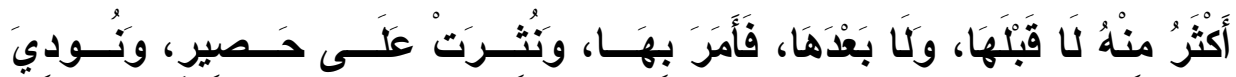

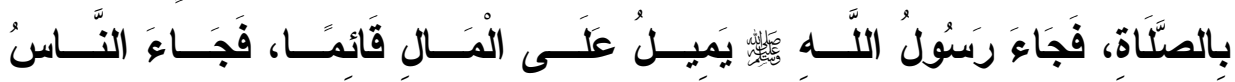

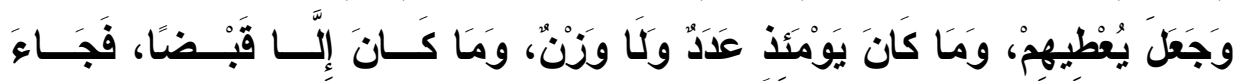

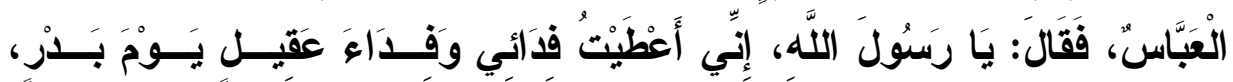

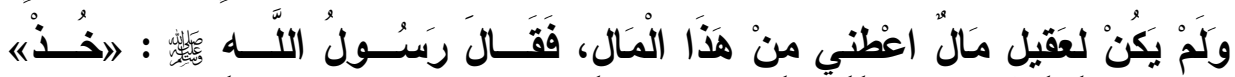

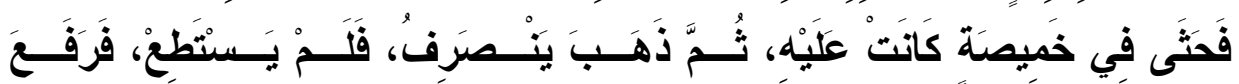

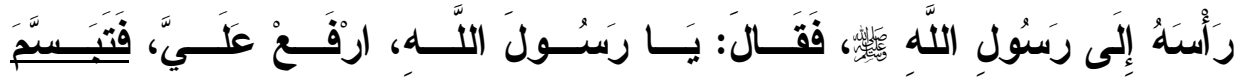

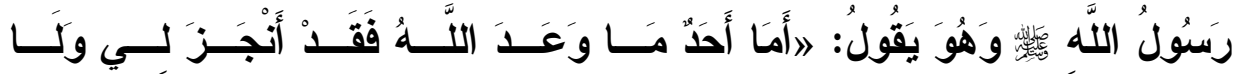

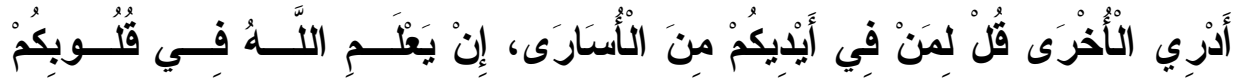

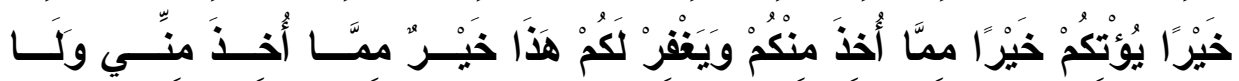

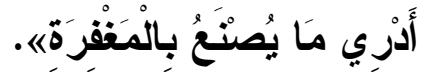

\section{تخريج الحديث:}

الحديث أخرجه الحاكم فـي المـستدرك (

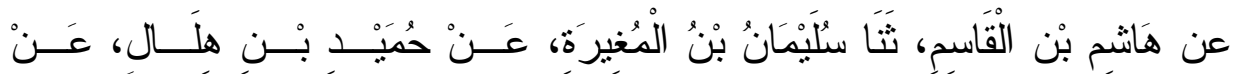

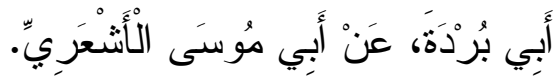
قال الحاكم: هذا حديث صحيح على شرط مُسلم ولم يخرجاه. 
ورجال إسناده من هاثم بن القاسم فمن بعده كلهم ثقات.

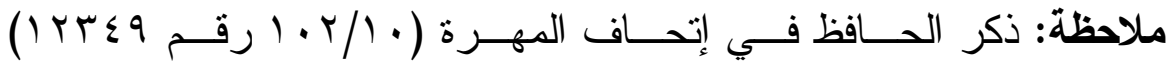
أن الطريق الثانية التي أوردها الحاكم ليس فيها (عن أبي بردة). لكن الموجود في مستدرك الحاكم في الموضــعين بإثبــات (أبــي بـردة) في الموضعين. انظر: مستدرك الحاكم طـ الهنديــة (الموضــع الــسابق)، وط مؤسـسـة آل إبر اهيم الخيرية وبهامشه تعليقـات البيهةــي و الــذهبي و ابــن الملقـن و ابــن

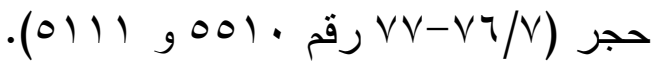
وقد علقه البُخاري في صحيحه: كتاب الـصـلاة، بــاب القـسمة وتعليـق

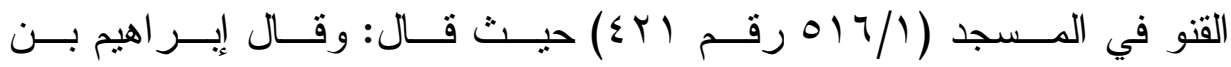
عبد العزيز بن صهيب عن أنس فذكر نحوه.

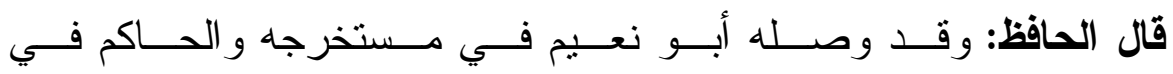
مستدركه من طريق أحمد بن حفص بـن عبــــ الله النيـسابوري عـن أبيـــه عن إبر اهيم بن طهمان، وقد أخرج البخاري بهذا الإســنـاد إلــى إبــر اهيم بـن

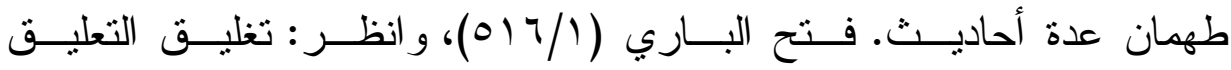
$\cdot(r Y \Lambda-r Y T / r)$

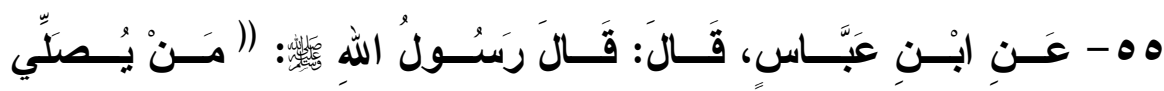

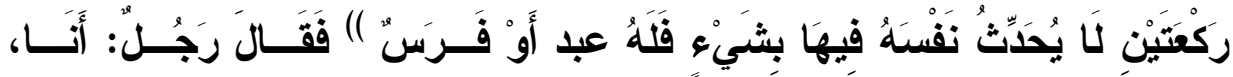

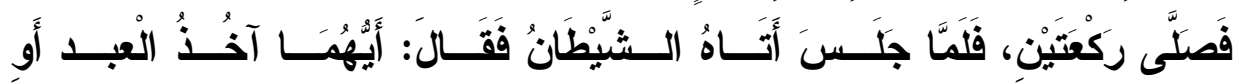

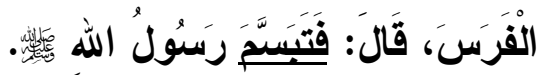




\section{تخريج الحديث:}

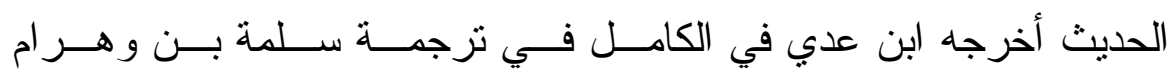

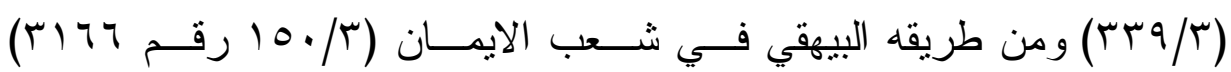
قال:

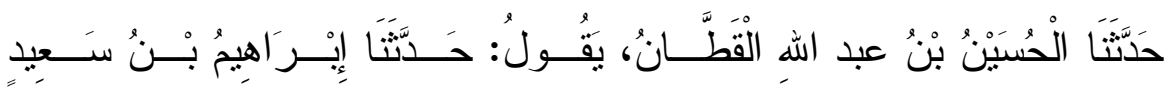

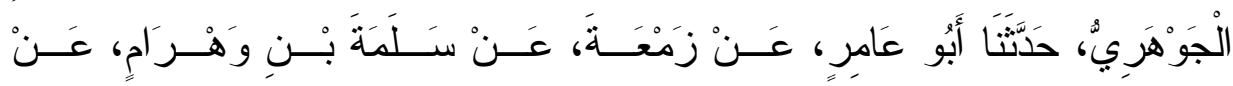
عَكِرِمَةَ، عَنْ ابْنِ عَبَّاسِ

وفي إسناده صاحب التزجمة: سلمة بن وهر ام نقل فيـهـ ابـن عــدي فـي

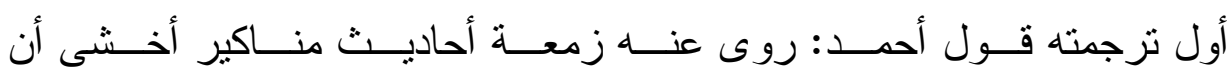

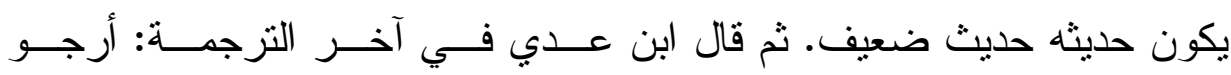
أنه لا بأس برو اياته هذه الأحاديث التي يرويها عنه زمعة.

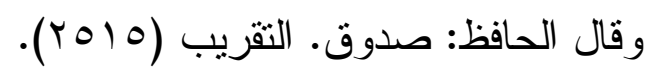

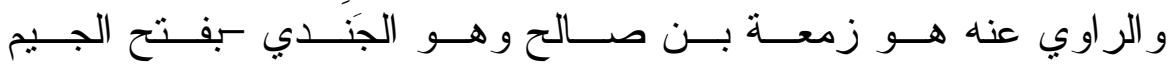

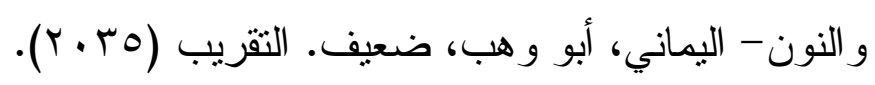
و عليه فإسناد الحديث ضعيف.

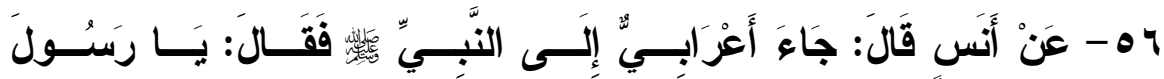

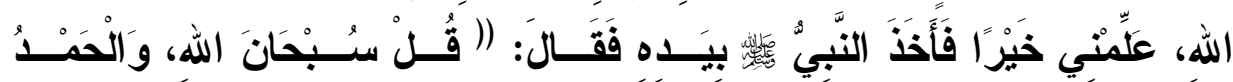

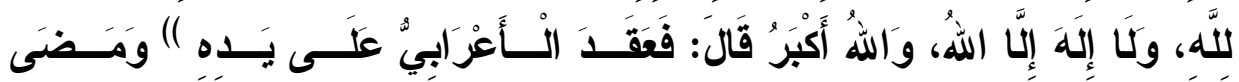

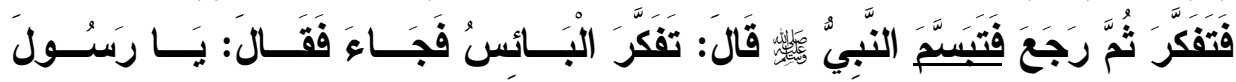

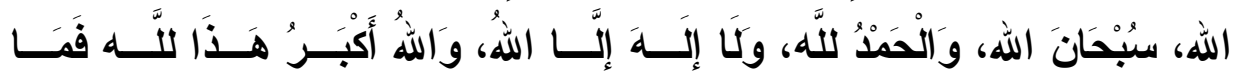

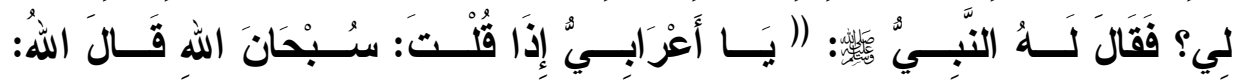

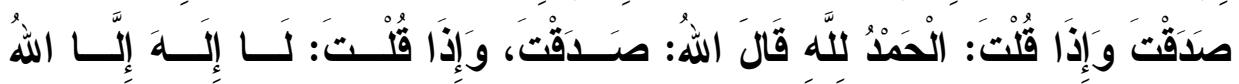




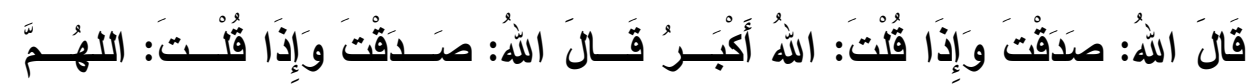

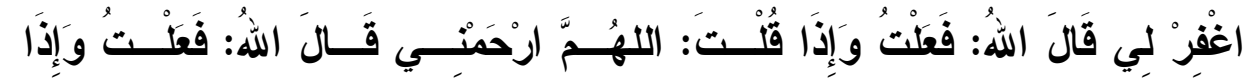

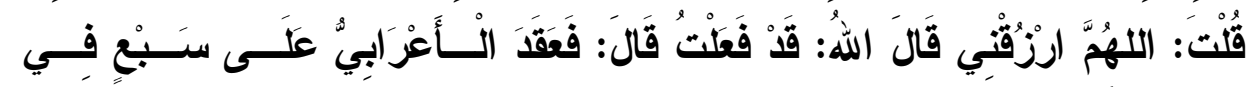

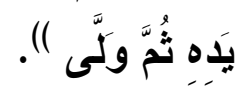

\section{تخريج الحديث:}

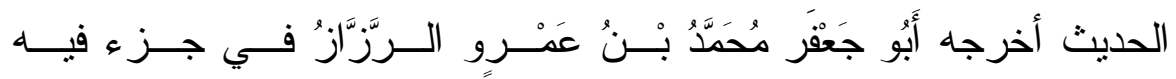

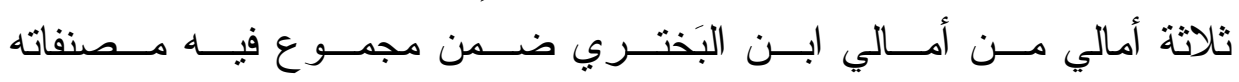

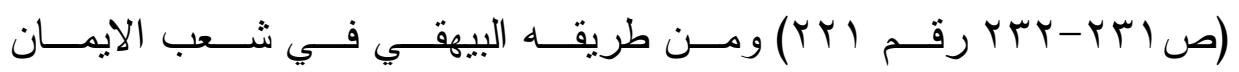
(1/1)

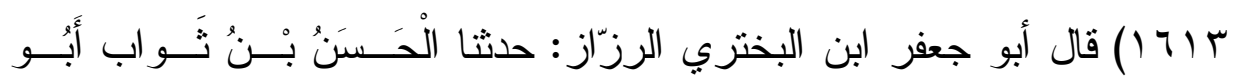

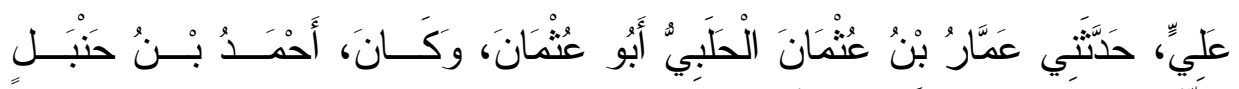

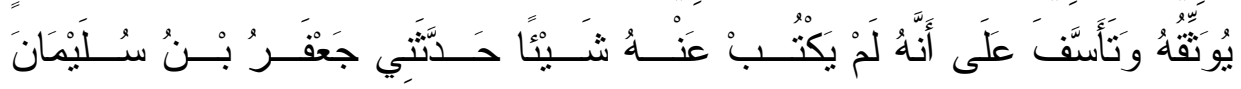

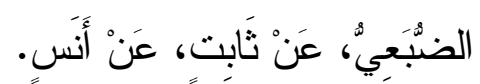

و إسناده حسن، فيه الحسن بن ثــواب: قــال الــــر اقطني: ثقـــة، وذكـــره

$$
\text { انظ حبان في النقات. }
$$

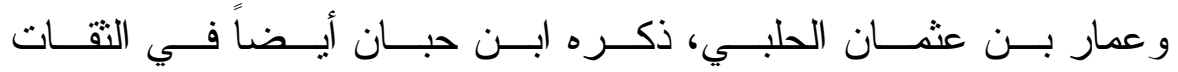

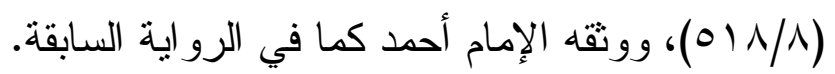

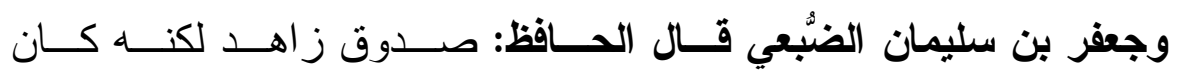

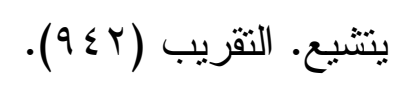

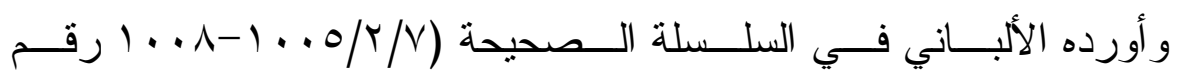




\section{المبحث |لسادسل}

\section{الأحاديث الواردة في تبسم النبي}

ه - OV تبوك، وفي الحديث قَالَ كَعْبُ بْنُ مَالكَ:

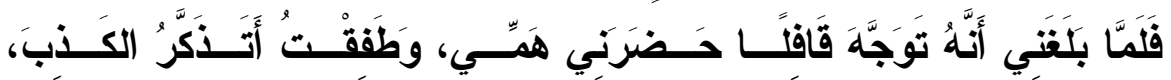

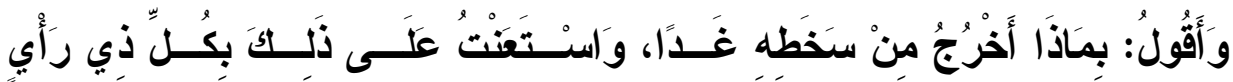

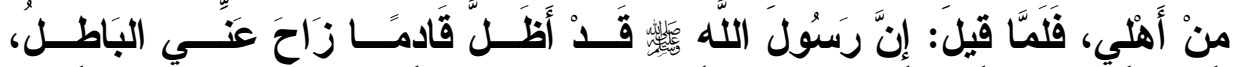

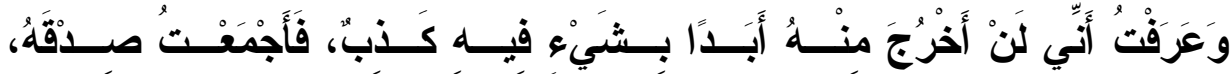

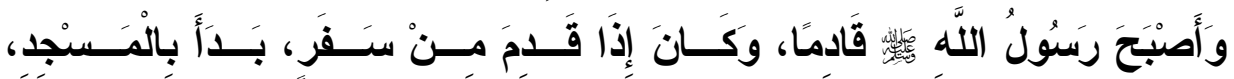

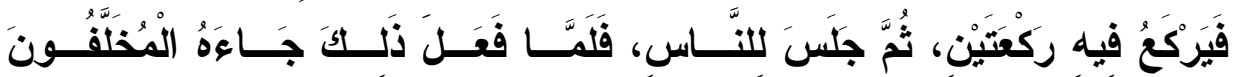

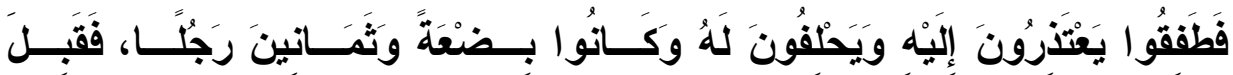

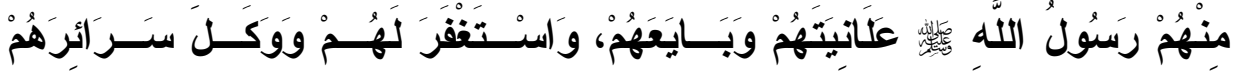

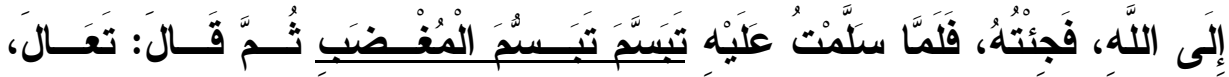

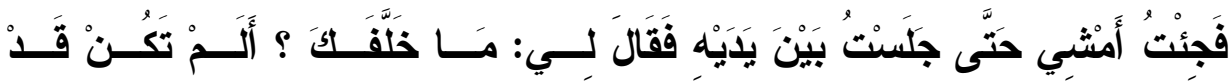

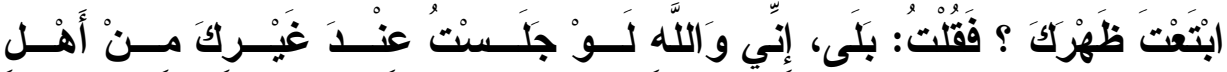

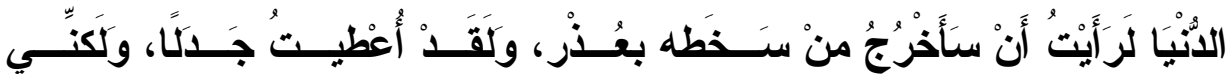

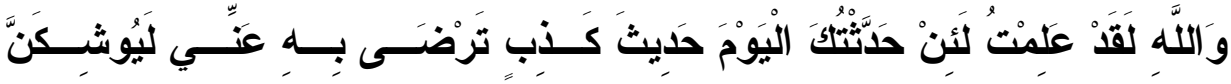

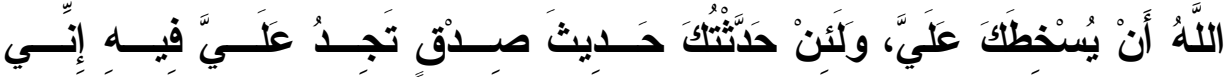

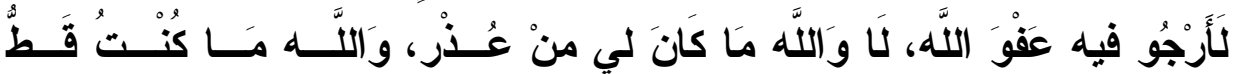

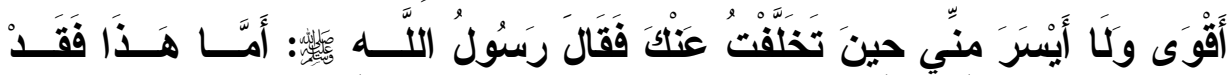

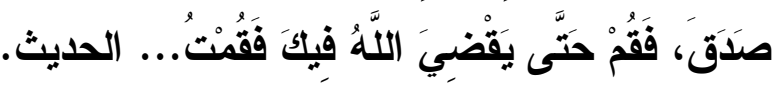




\section{تخريج الحديث:}

الحديث أخرجه البخــاري: كتــاب المغـــازي، بــاب حــديث كعــب بـن

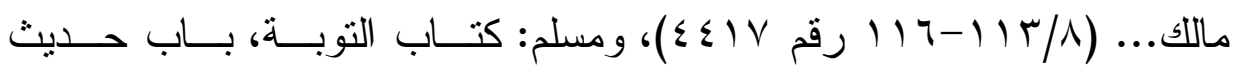

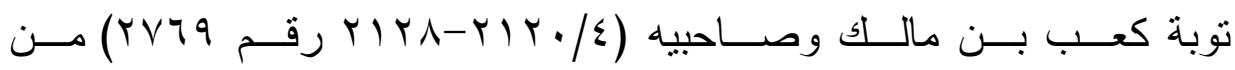

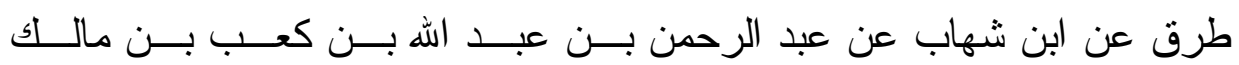
عن عبد الله بن كعب بن مالك عن أبيه به.

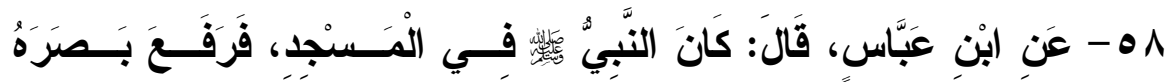

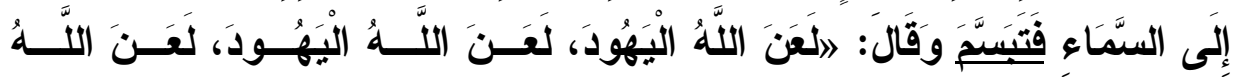

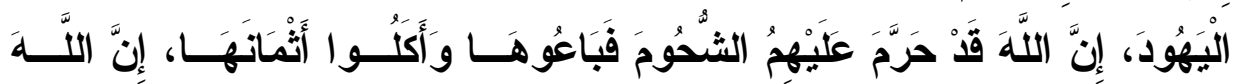

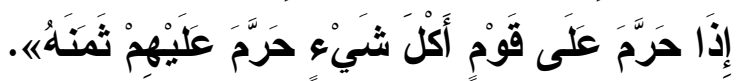

\section{تخريج الحديث:}

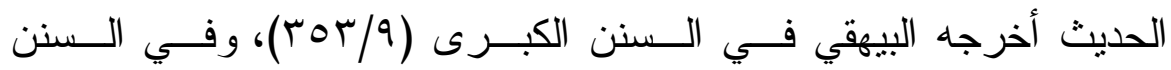

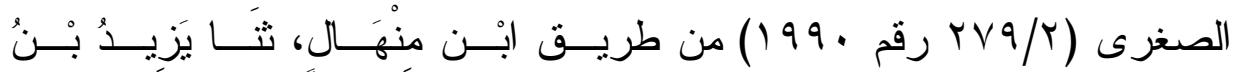

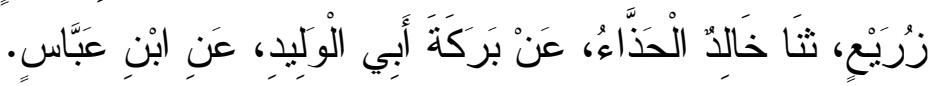

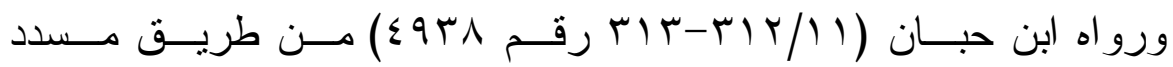
عن يزيد بن زريع، ولم يذكر فيه: (فتبسم).

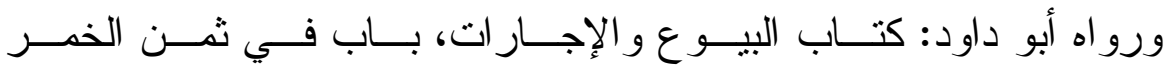
و الميتة (س/

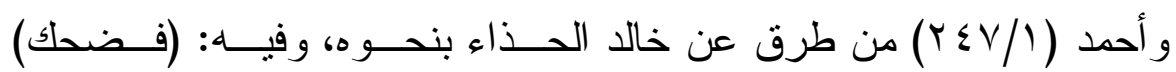
بدل (فتبسم). و إسناد الحديث رجاله ثقات.

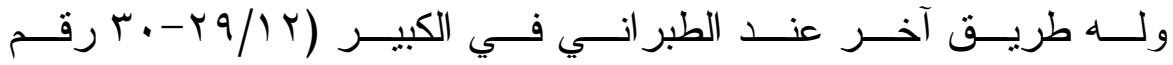
( ) R MVA

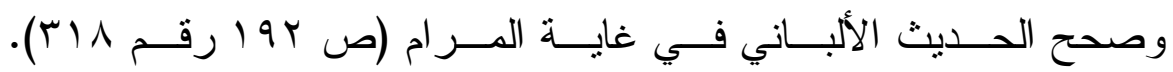




\section{المبحرغ |لسابع}

\section{الأحاديثث الهاردة في تبسم النببي}

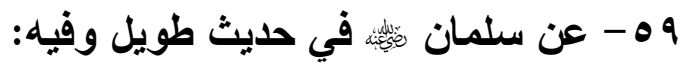

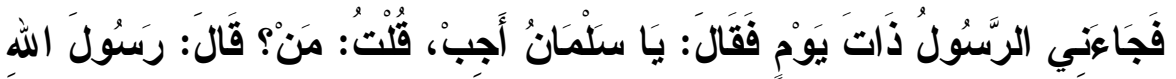

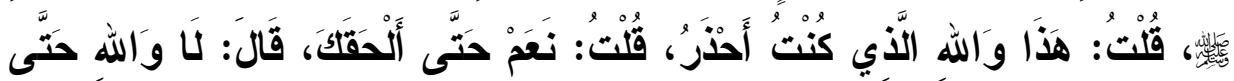

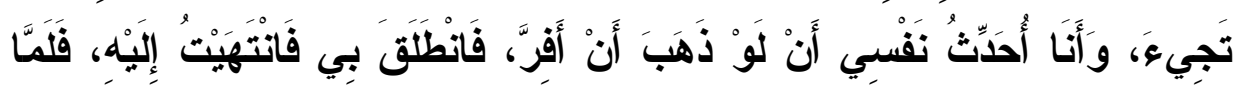

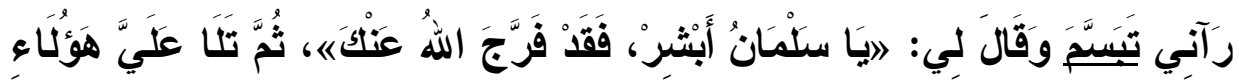

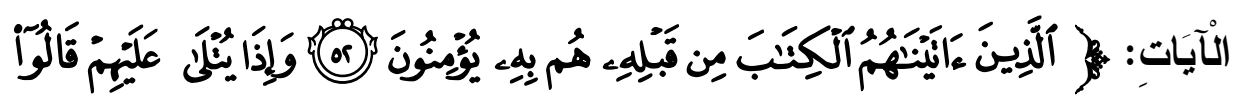

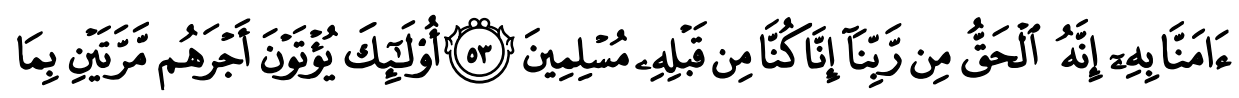

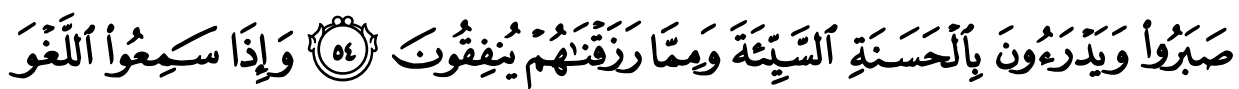

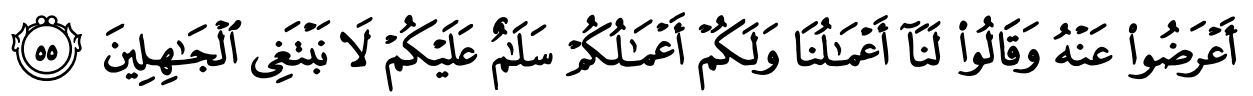

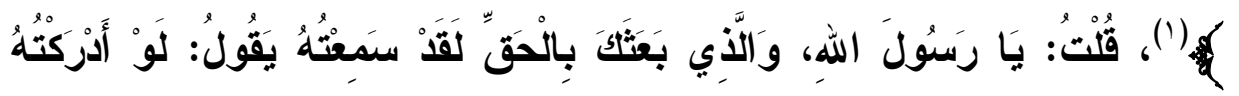

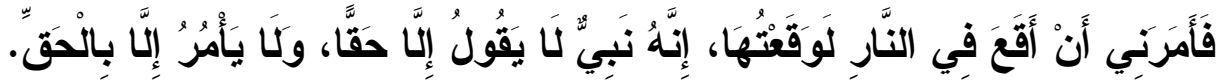

\section{تخريج الحديث:}

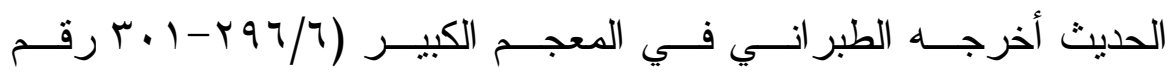

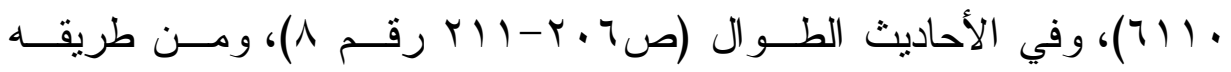

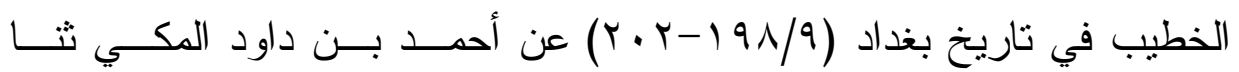

$$
\text { سورة القصص آية رقم: (ro-O0). (Y). }
$$


قيس بن حفص الدارمي ثنا مسلمة بن علقمــة المــازني ثتـــا داود بــن أبــي هند عن سماك بن حرب عن سلامة العجلي عن سلمان.

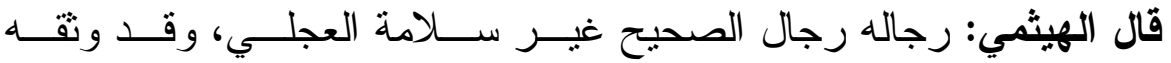

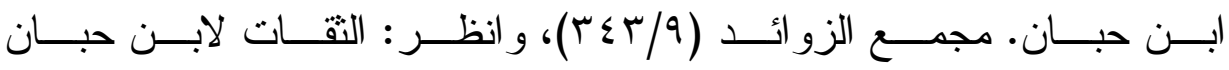
$\cdot(r \leq r / \varepsilon)$

وقال الأهبي: غريب جــدا، وســلامة لا يعـرف. ســير أعــلام النــبلاء .$(0 \mathrm{rv} / 1)$

• -

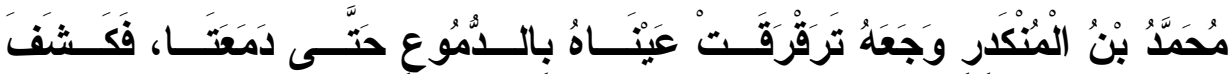

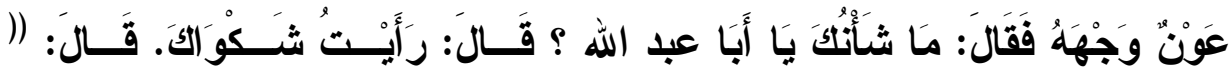

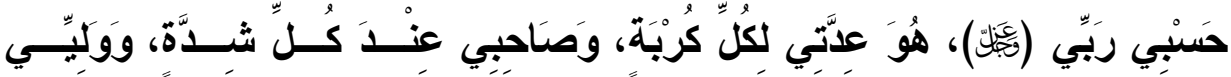

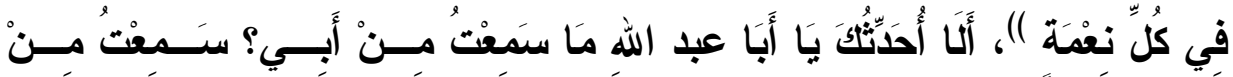

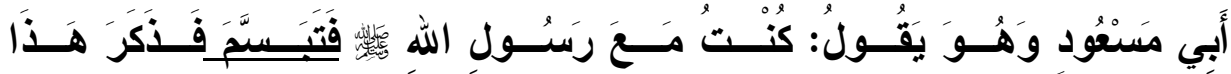
الَْحَيثَ.

\section{تخريج الحديث:}

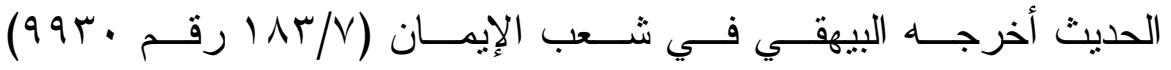

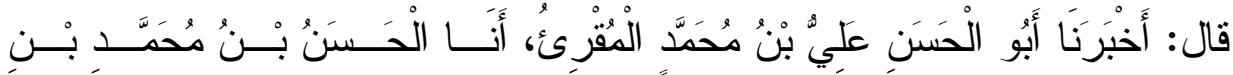

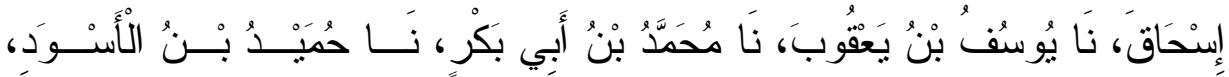

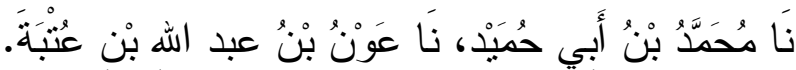

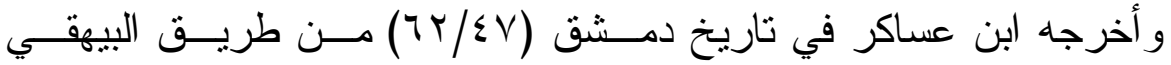

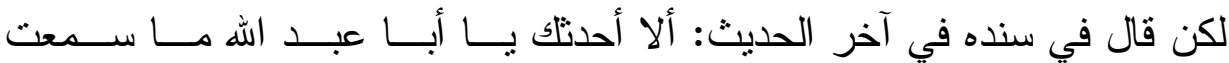
أبي سمعه عن ابن مسعود. 


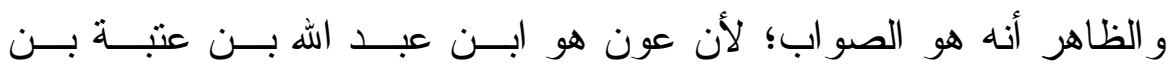

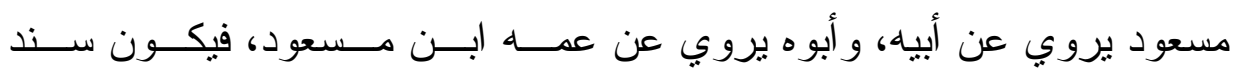

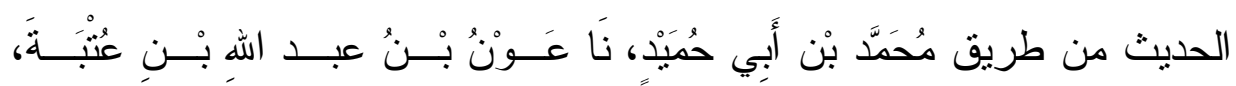
عن أبيه، عن ابن مسعود.

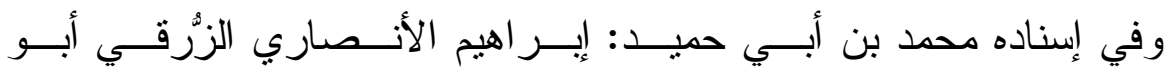

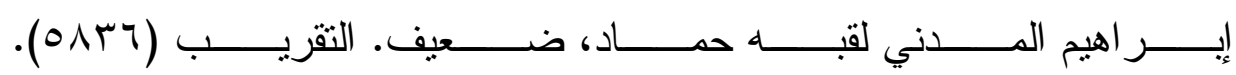




\section{الهبحث |لثامن}

\section{الأحاديث الواردة في تبسم النببي}

ا 1

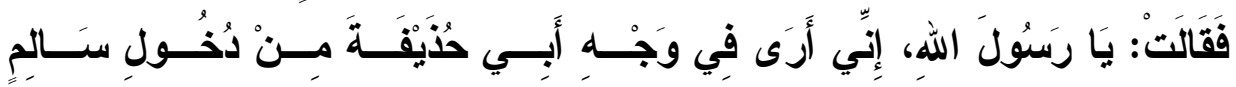

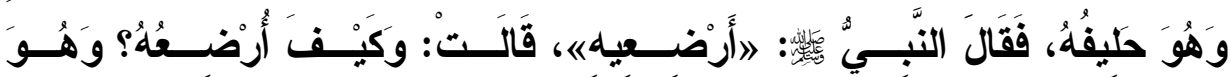

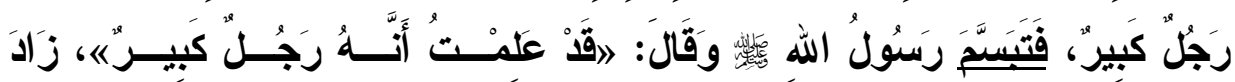

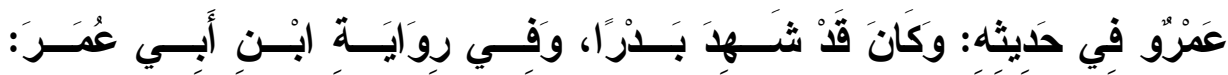

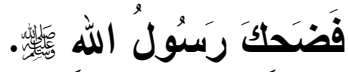

\section{تخريج الحديث:}

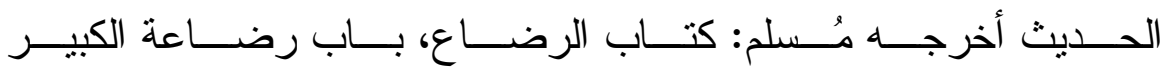

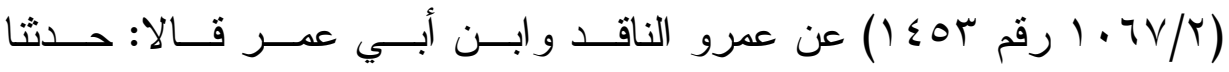
سفيان بن عيينة عن عبد الرحمن بن القاسم عن أبيه عن عائشة.

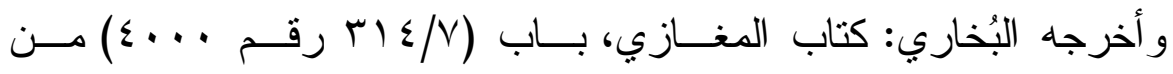

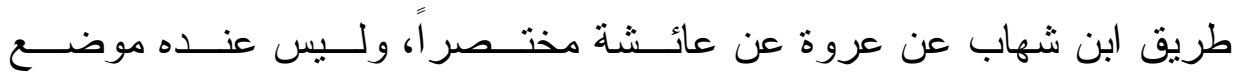
الثـاهد.

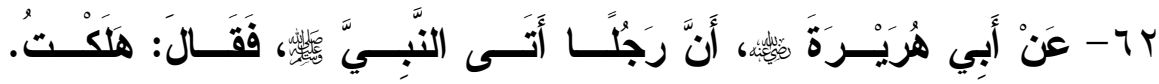

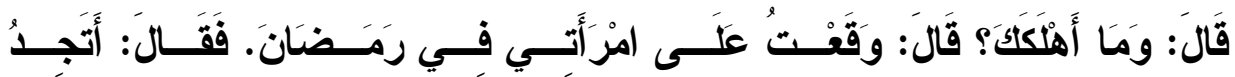

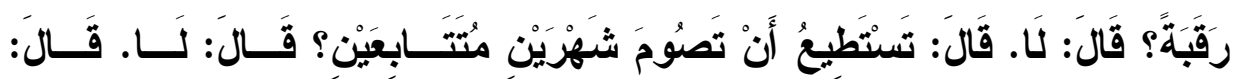

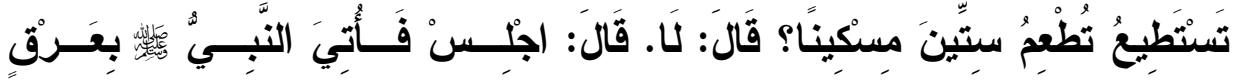

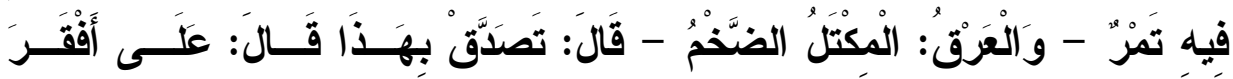




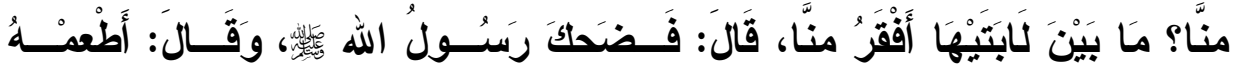

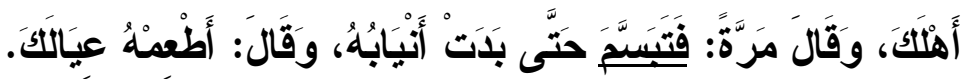

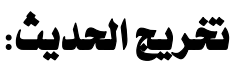

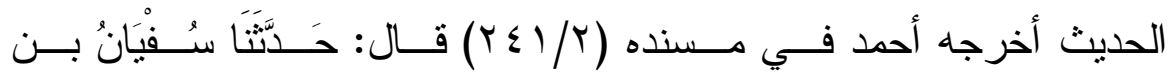

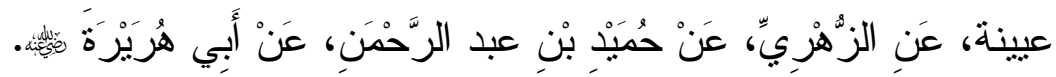

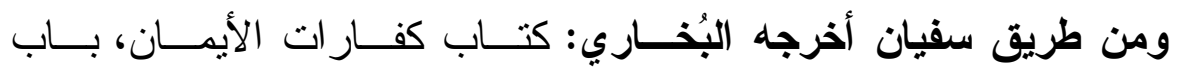

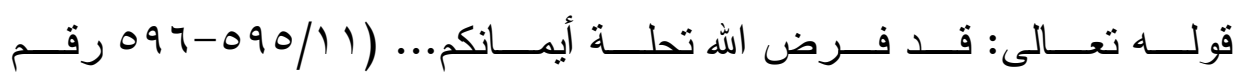

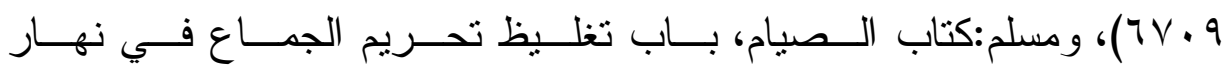

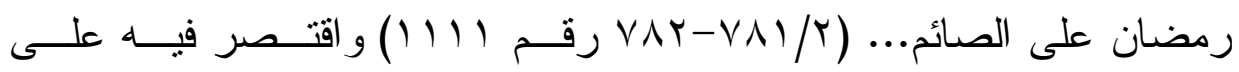

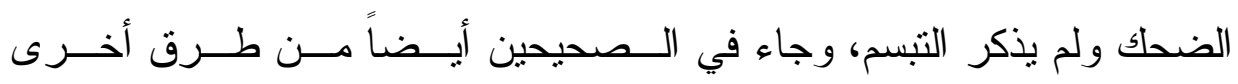
بنحوه.

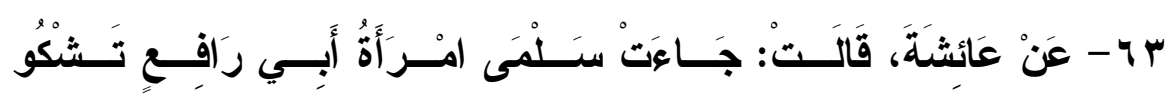

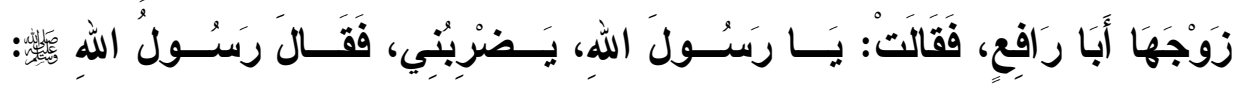

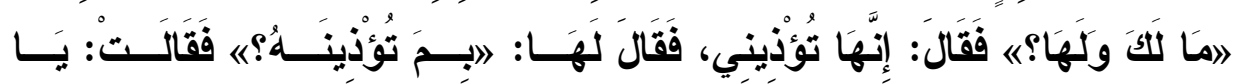

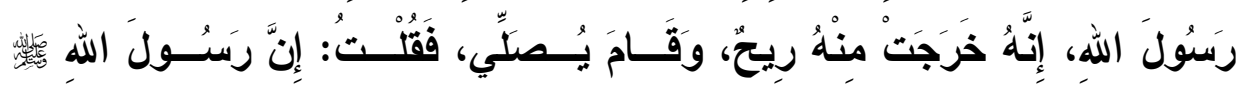

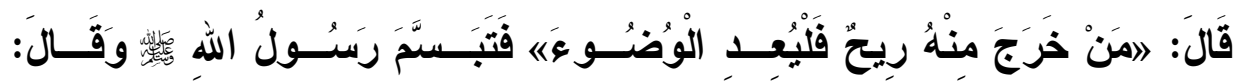

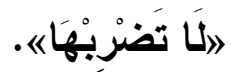

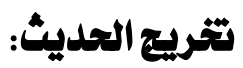

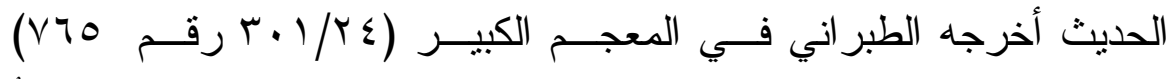

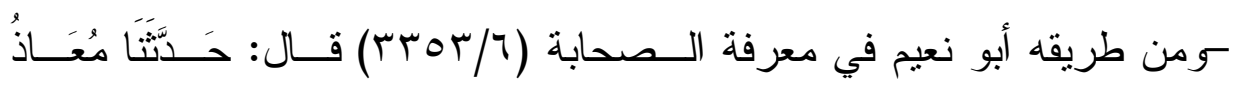

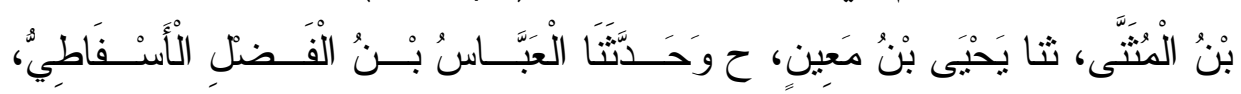




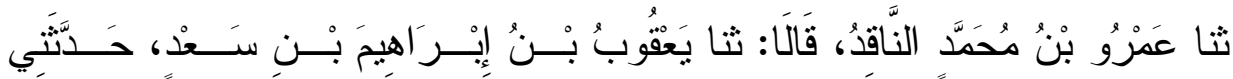

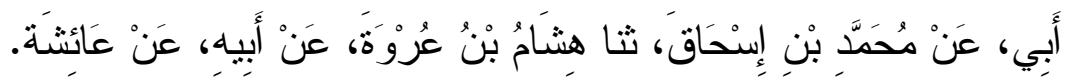

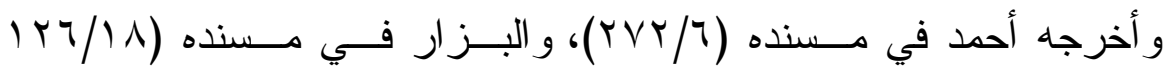

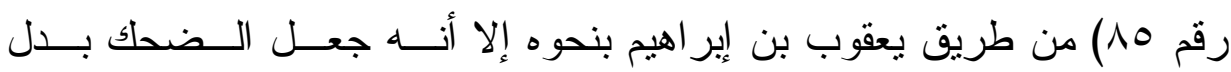
التبسم.

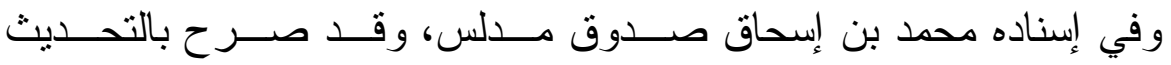
كما في رواية أحمد. و أثنار البُخاري وأبو زرعة و البزار إلى أنه قد تقرد به.

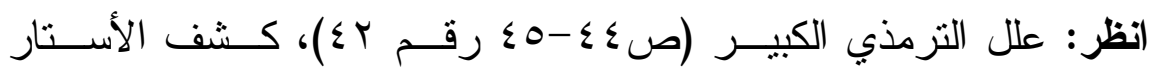
( $(r \wedge \cdot 1 \leqslant \vee / 1)$

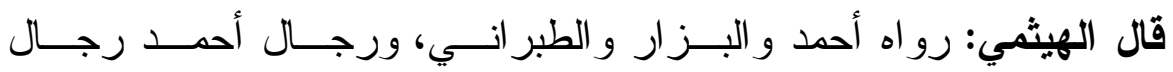
الصحيح، إلا أن فيه محمد بن إسحاق، وقد قال: حـدثثي هـــام بــن عـروة،

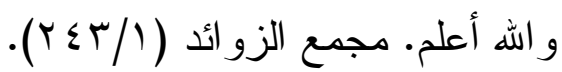

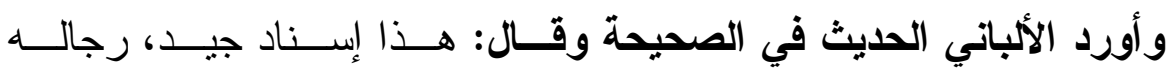

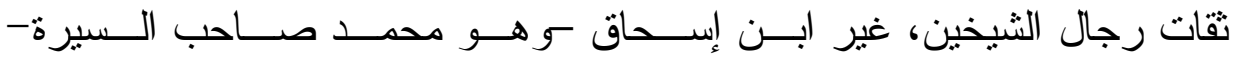

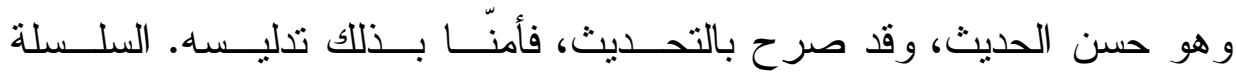

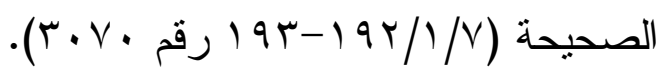

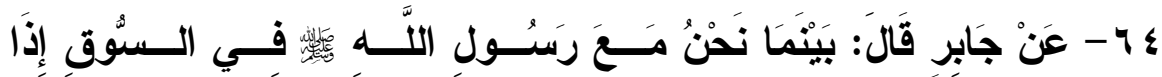

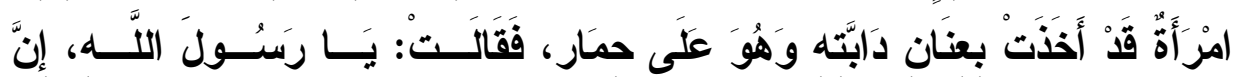

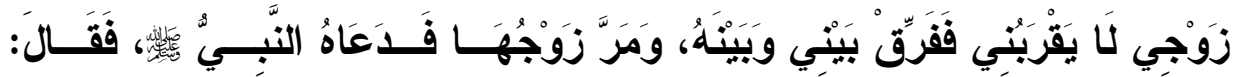

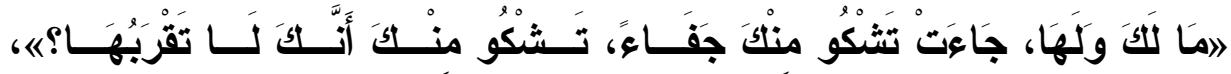




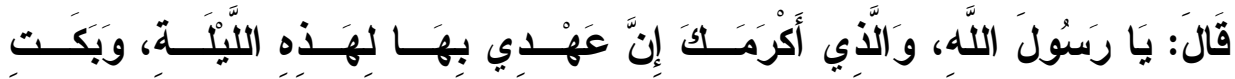

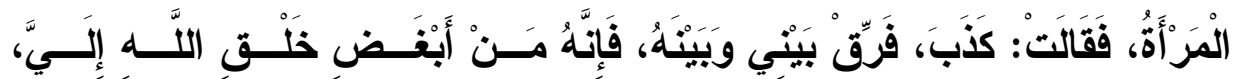

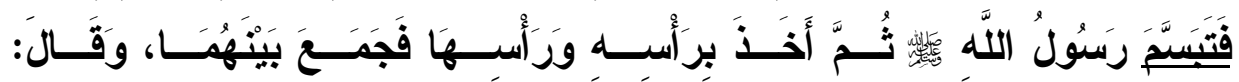

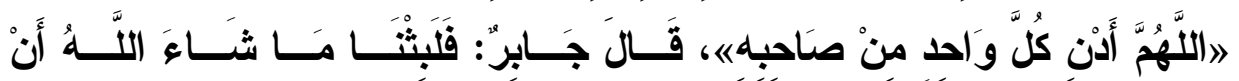

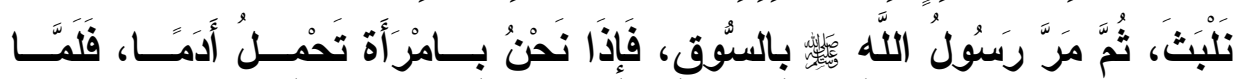

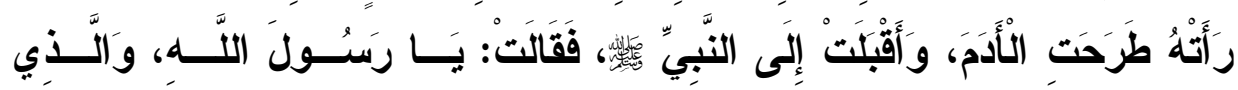

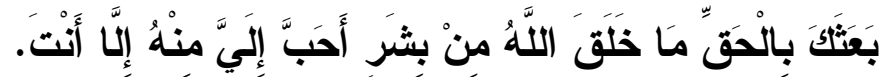

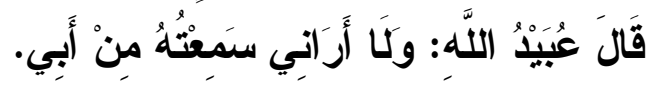

\section{تخريج الحديث:}

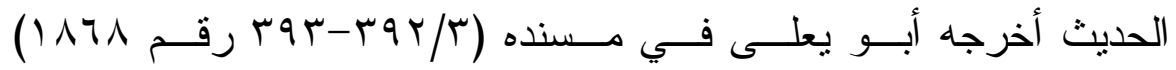

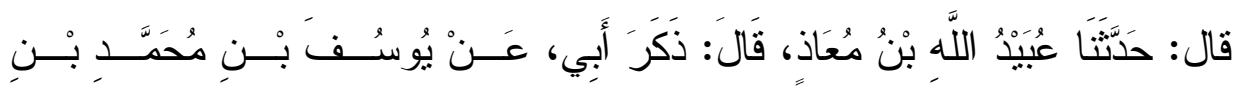

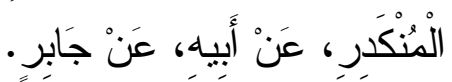

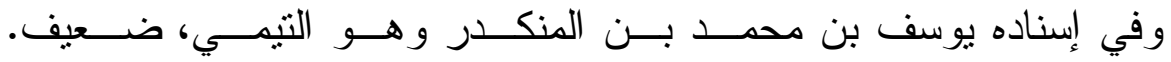

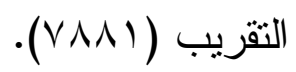

قال الهيثي: ور اه أبو يعلى، ورجالــهـ رجـال الــصحيح غيـر يوســف

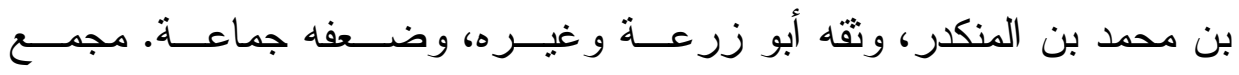

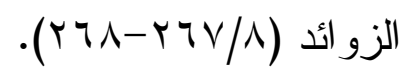

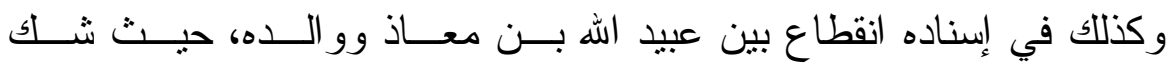
في سماعهاه هذا الحديث منه كما ذكر ذلك بنفـسه فـي نهايــة الحــديث حيــث قال : وَكَا أَرَانِي سَمَعْتُهُ مِنْ أَبِي. 


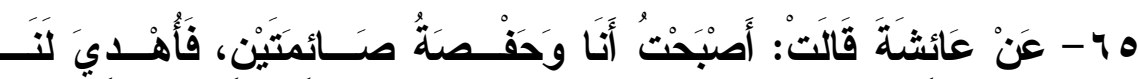

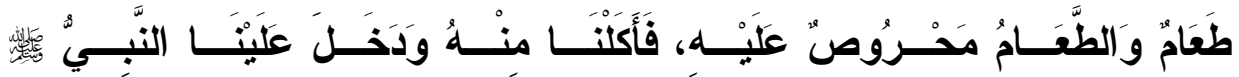

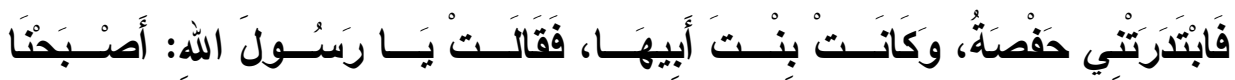

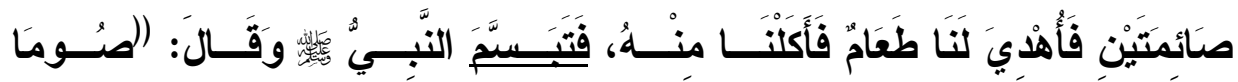

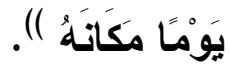

\section{تخريج الحديث:}

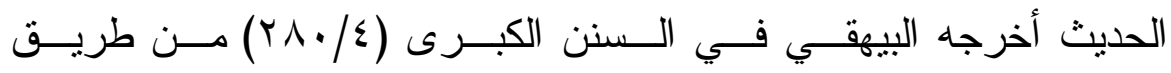

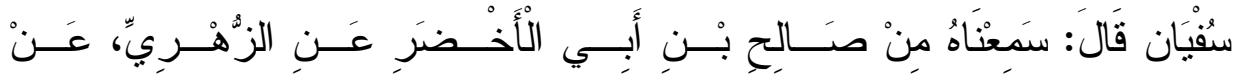

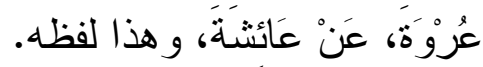

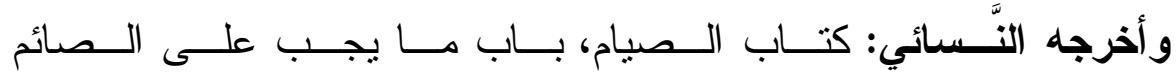

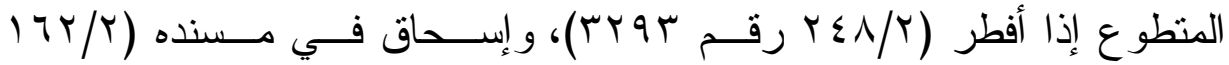
رقم • 7 آ) من طريق النضر بن شــميل عـن صــالح بـن أبــي الأخــر بنحوه، ولم يذكر التبسم. ورواه أيضا من غير ذكر التبسم:

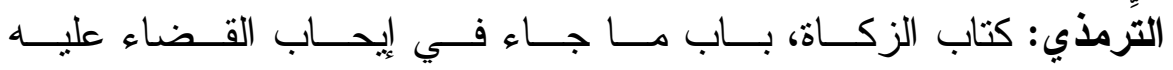

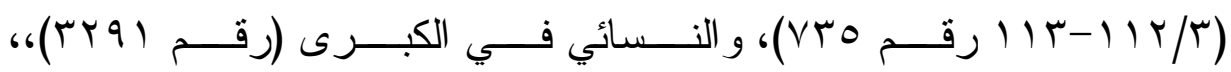

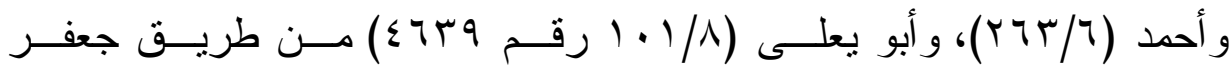

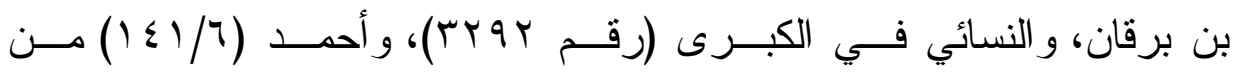

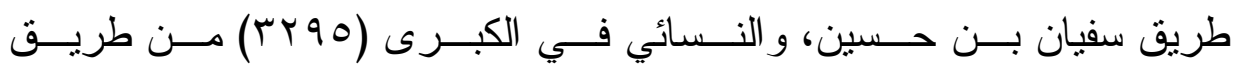

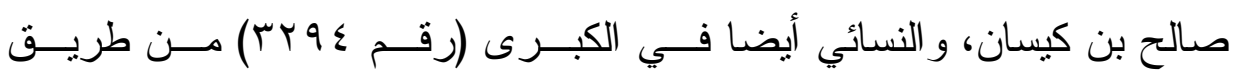
إسماعيل بن إبـر اهيم (أو إبـــماعيل بــن عقبـة)، و الطحــاوي فــي شــرح 


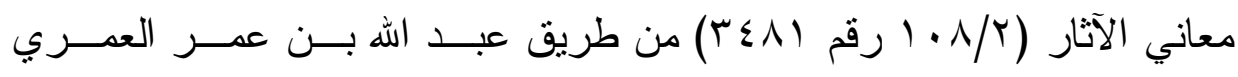
و غير هم كلهم عن الزهري عن عروة عن عائشة.

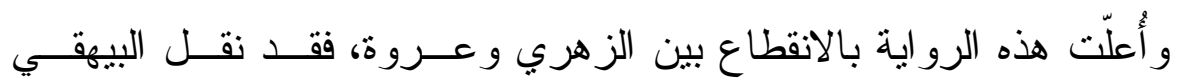

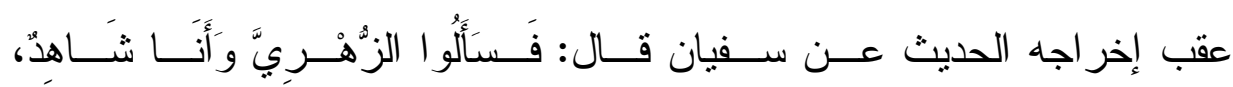

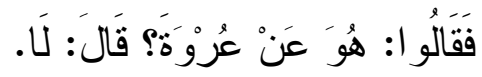

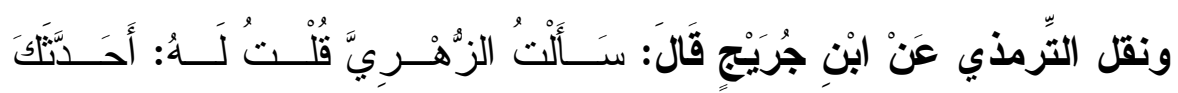

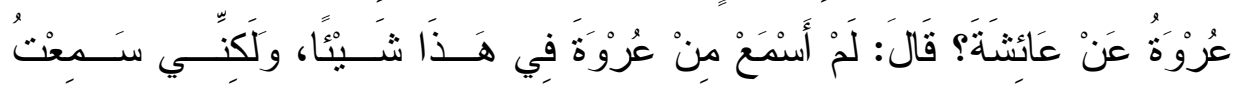

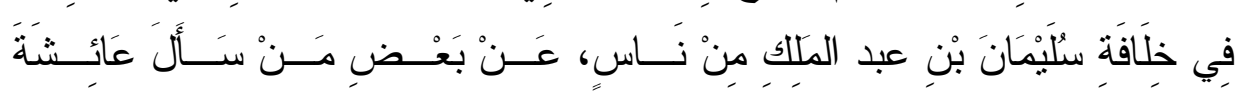

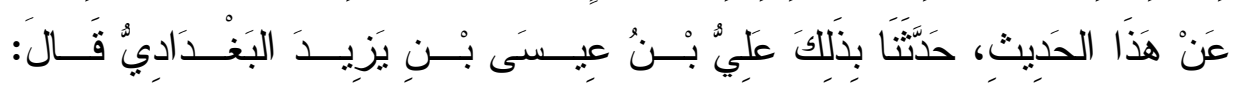

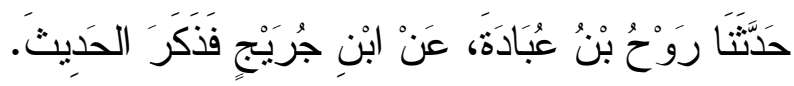

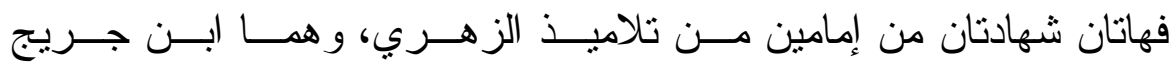

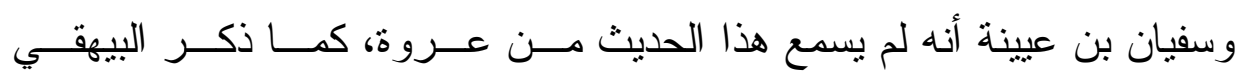

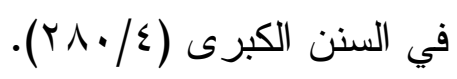

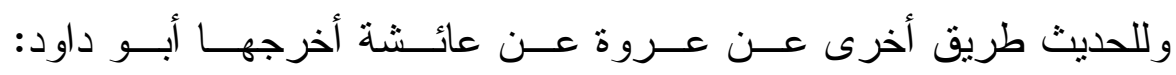

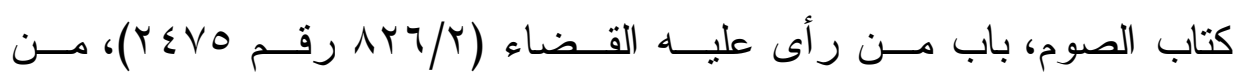
طريق ابن الهاد عن زميل مولى عروة عن عروة عن عائشة به.

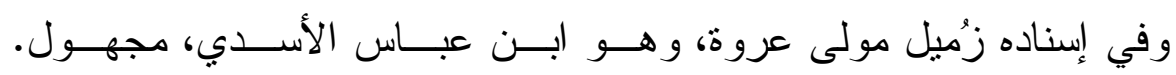

$$
\text { التقريب (דr • (ץ). }
$$

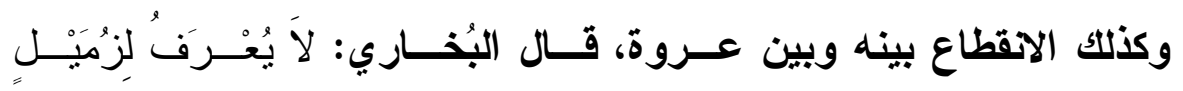

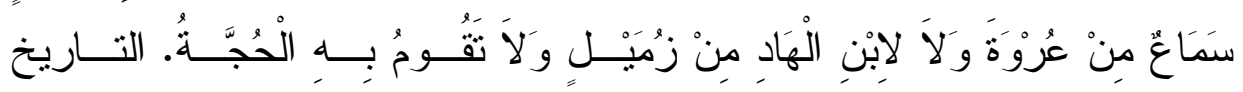

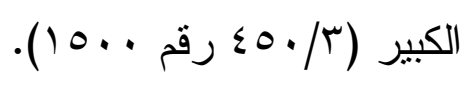


وله طريق أخرى عـن عمـرة عـن عائسشة، أخرجهـــا النَّسائي فـي

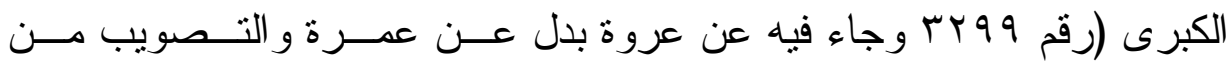

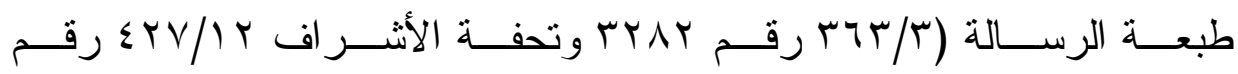

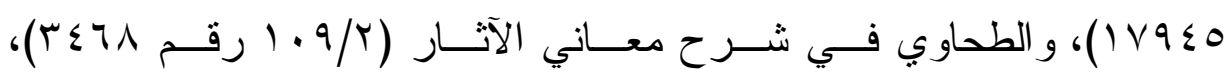

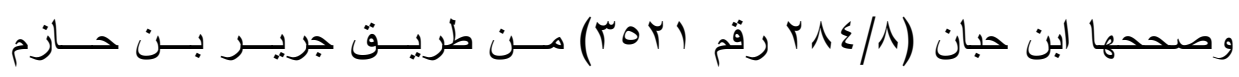
عن يحيى بن سعيد الأنصاري عن عمرة عن عائشة.

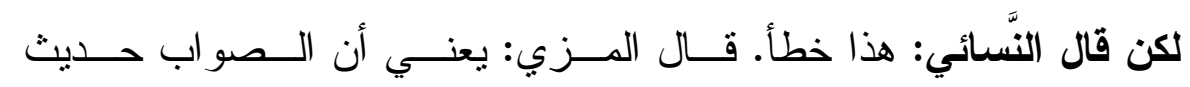
يحيى بن سعيد عن الزهري عن عروة عن عائشة.

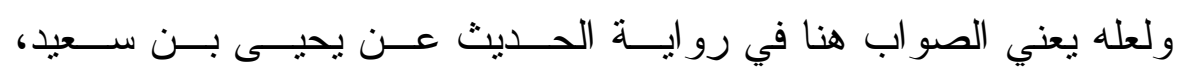
وليس على الاطلاق. - مات.

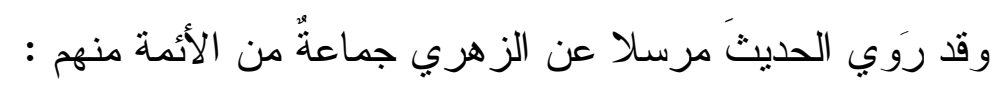

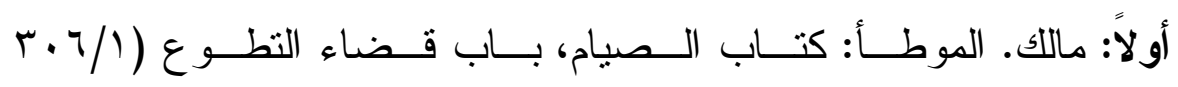

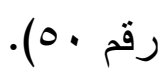

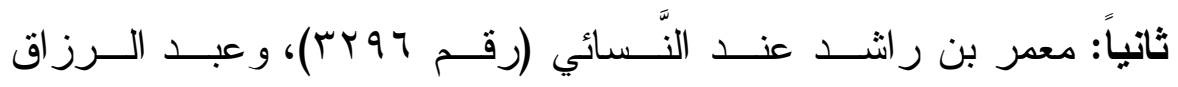

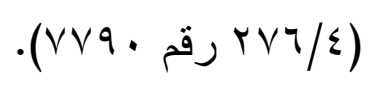

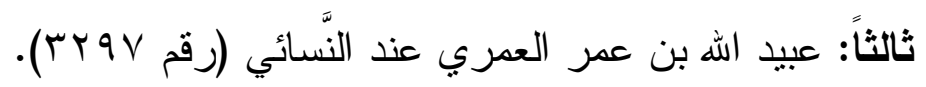

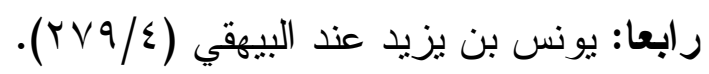
و غيرهم، أثنار إليهم البيهقي.

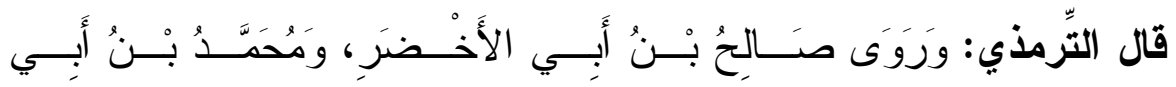

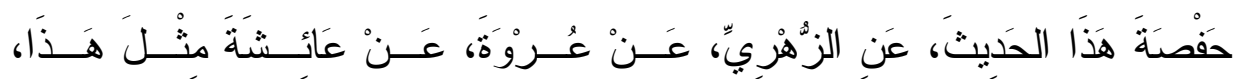

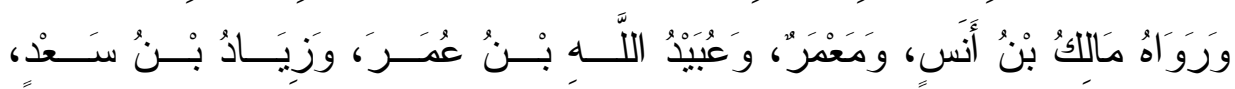

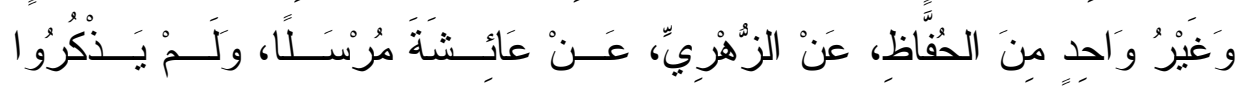




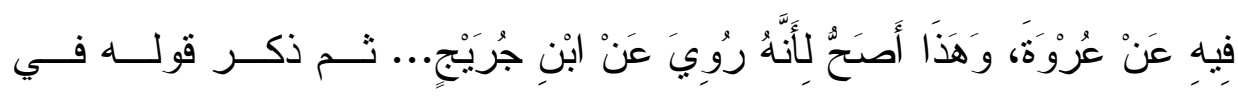
عدم سماع الزهري لهذا الحديث من عروة، وقد تقدم.

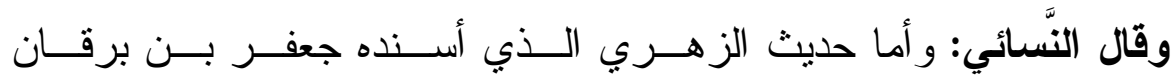

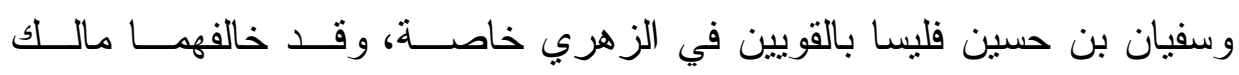

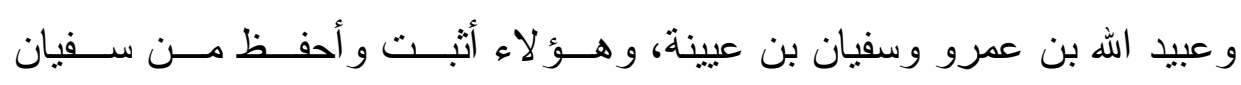

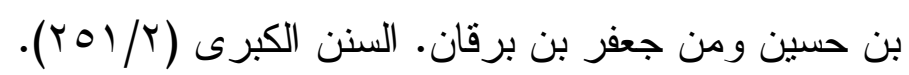

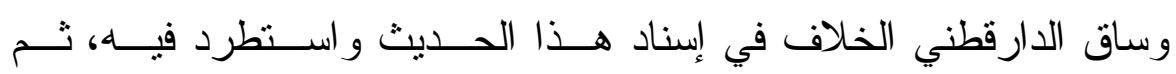
قال في آخر كلامه: ((لوليس فيها كلها شيء ثابت)، ثـــ ســاق الحـديث مــن

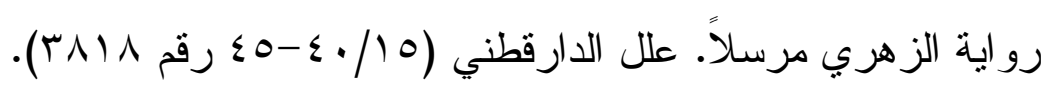

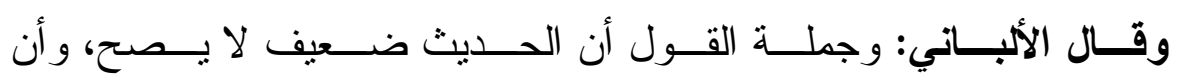

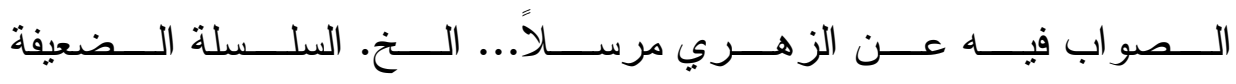

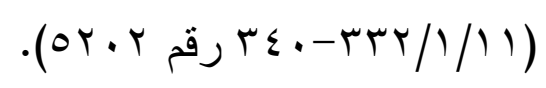




\section{الهبحث الناسع}

\section{الأماديث الواردة في تبسم النبي \\ | (المواب}

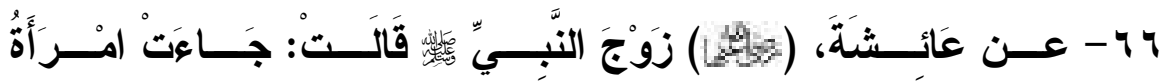

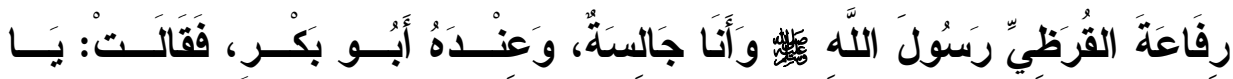

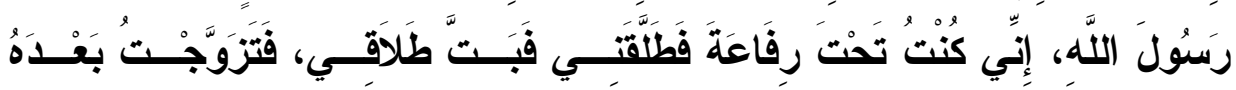

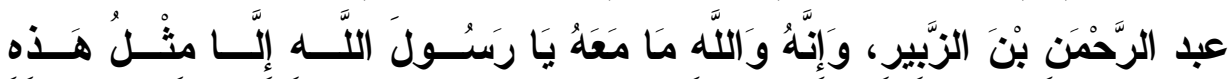

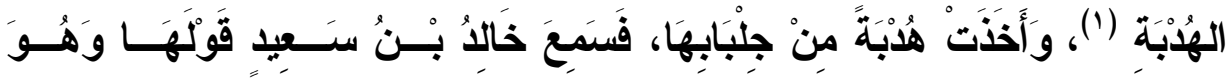

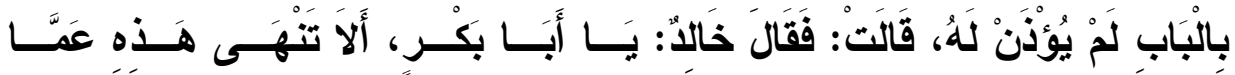

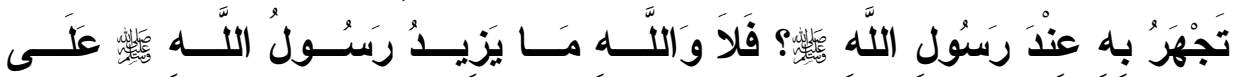

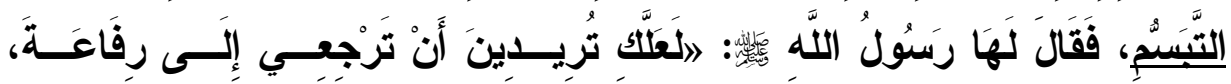

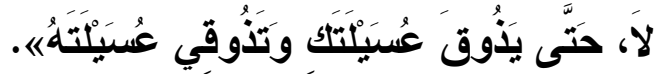

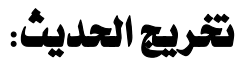

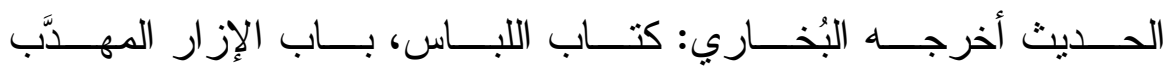

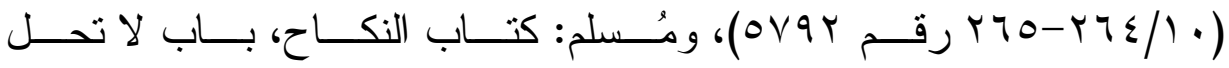

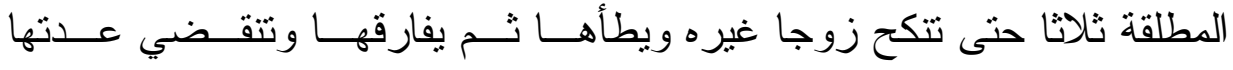

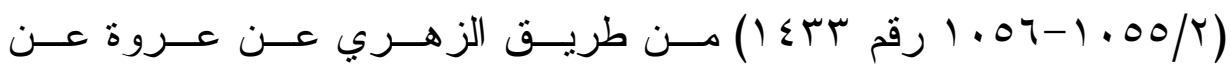

عائنة.

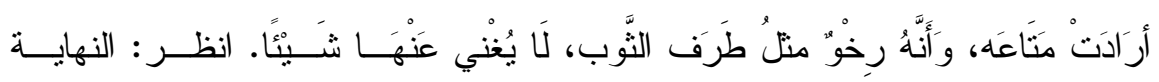

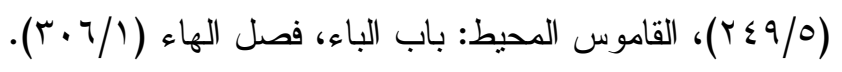




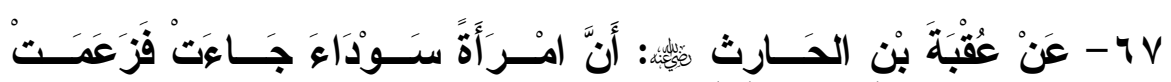

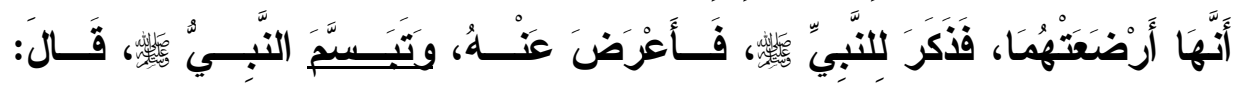

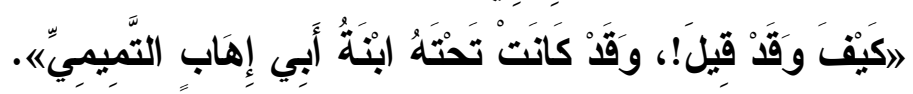

\section{تخريج الحديث:}

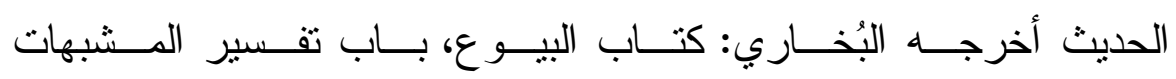

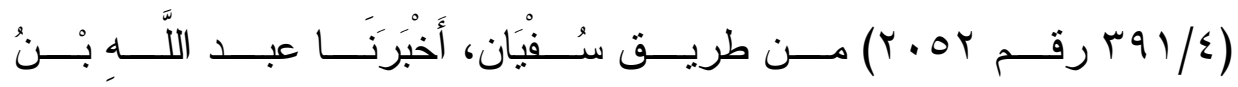

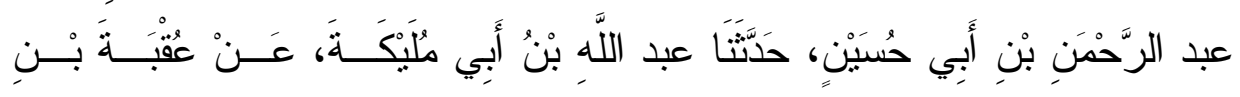
الحَارِثِ

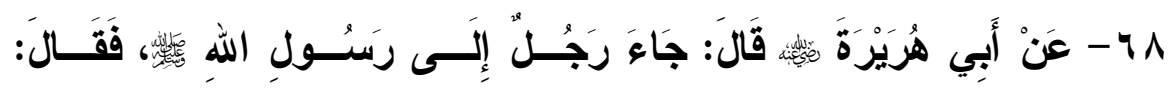

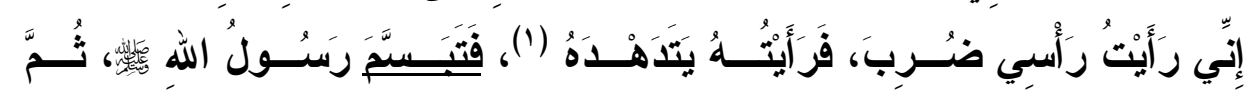

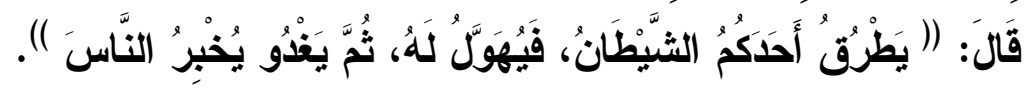

\section{تخريج الحديث:}

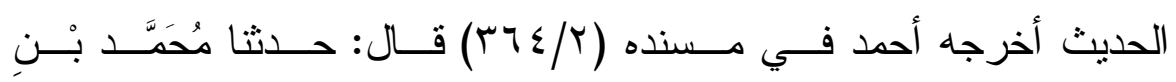

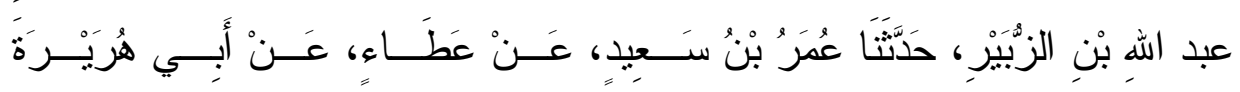

وأخرجه ابن ماجه في سنته: كتاب تعبير الرؤيــا، بــاب مــن لعــب بــــ

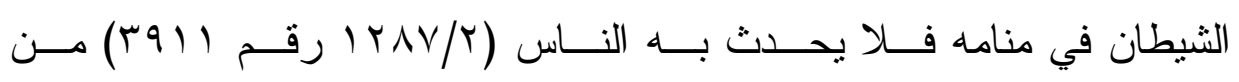

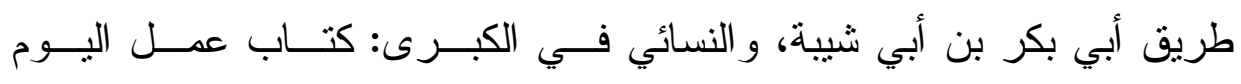

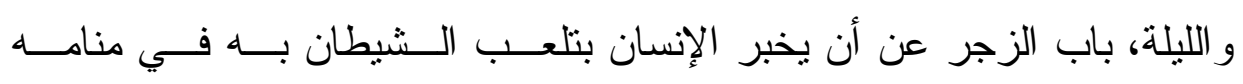




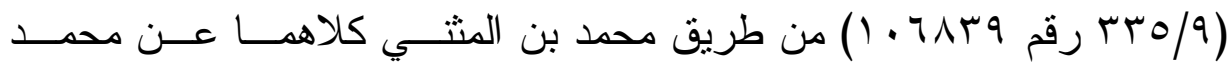

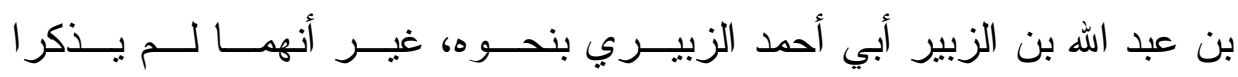
التبسم، و اقتصر النسائي على قوله: (فضحك). و إسناد الحديث رجاله كلهم ثقات.

وأخرج مُسلم فـي صـــيحه: كتــاب الرؤيــا، بــاب لا يخبــر بتلعــبـ

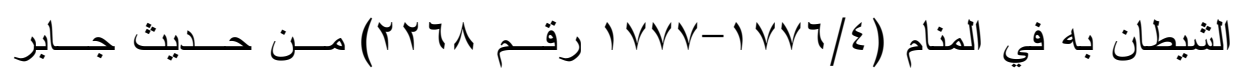

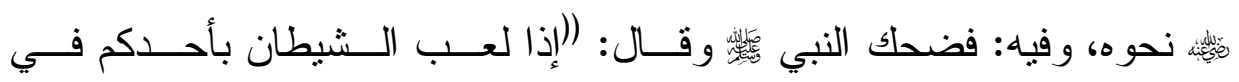

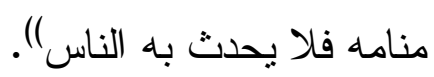

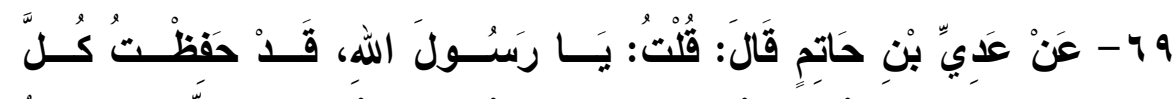

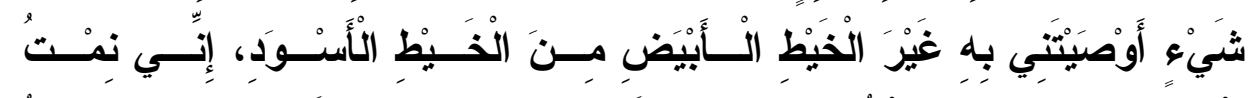

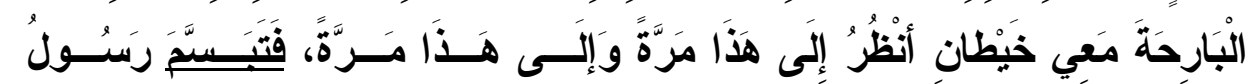
اللهِهِ السنَّمَاءعاء

\section{تخريج الحديث:}

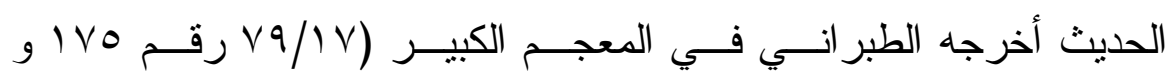

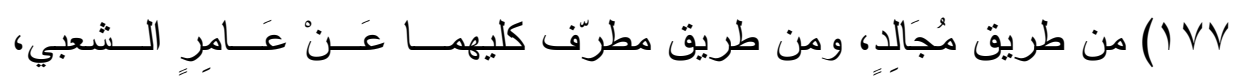
عَنْ عَدِيِّ بْنِ حَاتِمٍ. و الحديث أخرجه الــنيخان، البُخـــاري: كتهـاب الــصوم، بــاب قــول الله

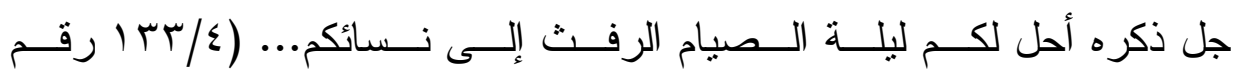

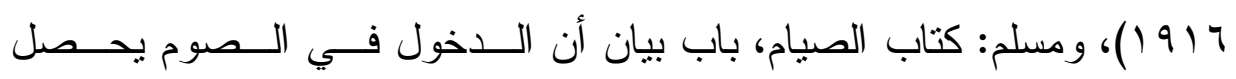

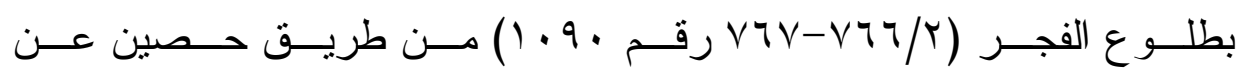
الثنببي 
وأخرجه البُخاري: كتاب التفسير، بــاب وكلــو ا و اثـــربو ا حتــى يتبــين

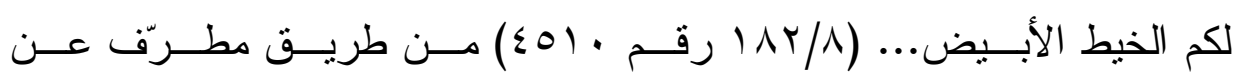
الثعبي

فذكر نحوه، غير أنه لم يرد فيه ذكر التبسم. 


\section{المبحث |لعاشر}

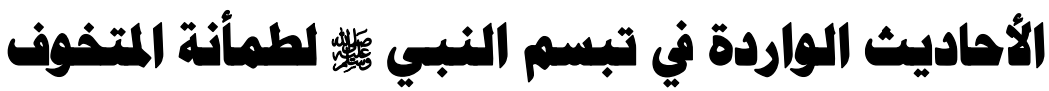

•

وفيه:

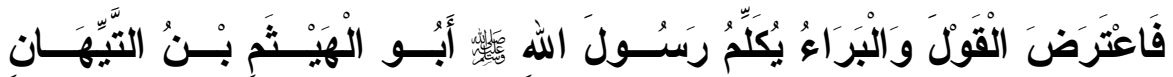

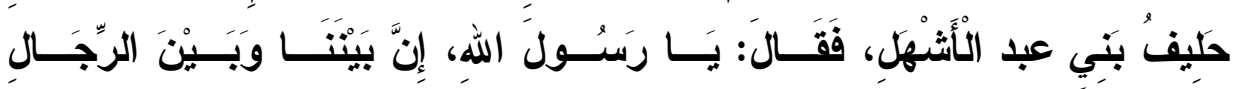

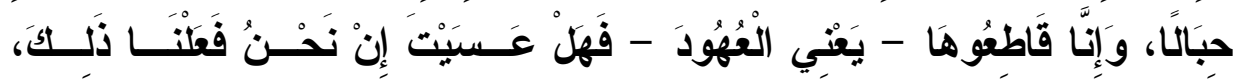

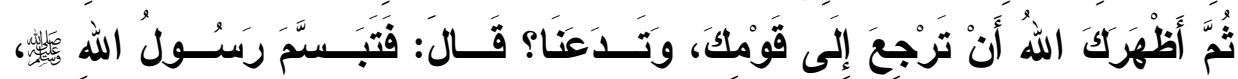

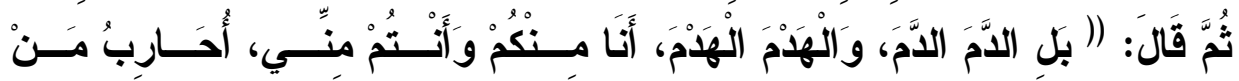

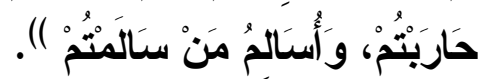

\section{تخريج الحديث:}

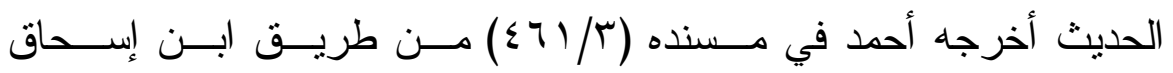

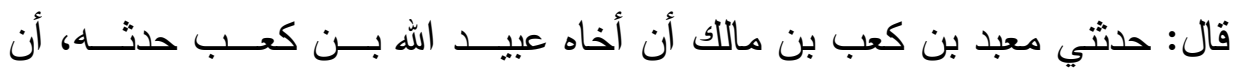

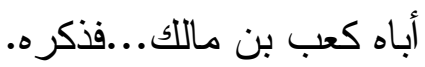
و أخرجه ابـن حبــان (10/

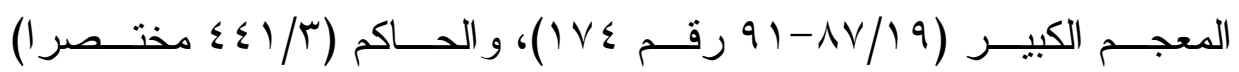
من طريق ابن إسحاق بنحوه، وليس فيه موضع الثـاهد في ذكر التبسم.

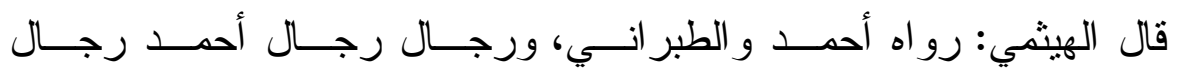
الصحيح غير ابن إسحاق، وقد صر ح بالسماع. مجمع الزو ائد (7/ ؛ ؛).

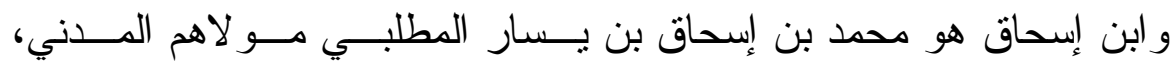

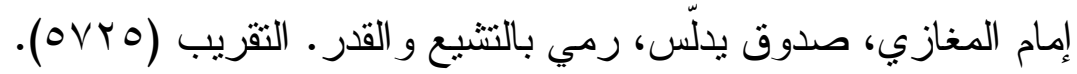

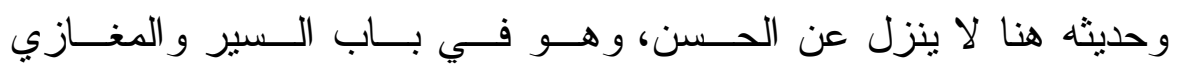
الذي هو إمامه. 


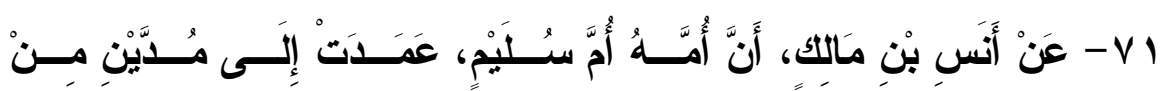

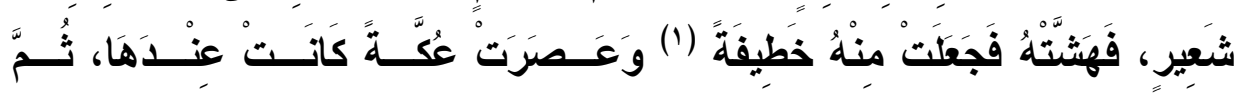

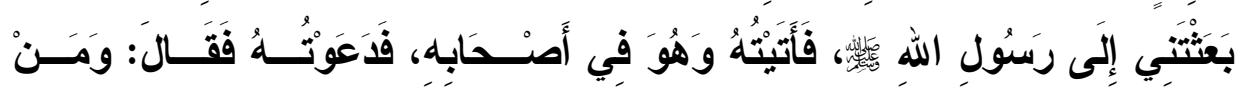

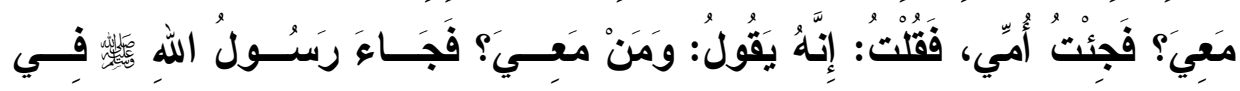

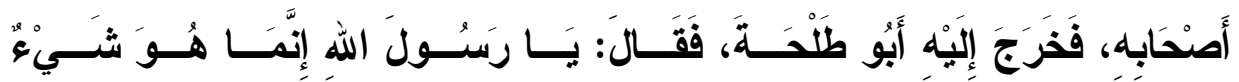

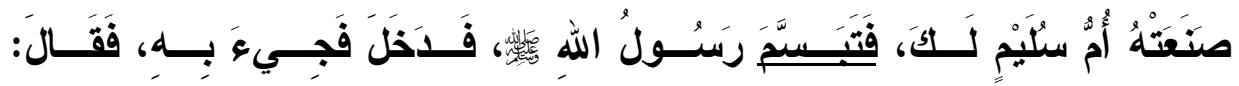

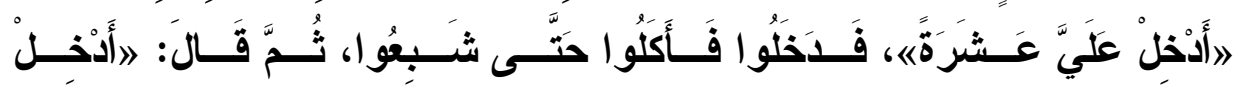

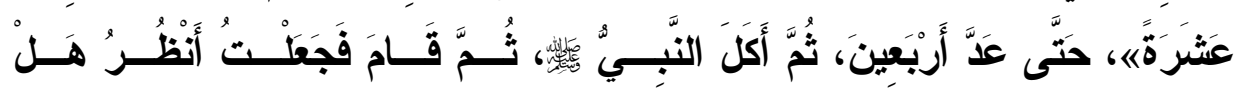

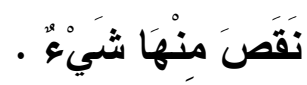

\section{تخريج الحديث:}

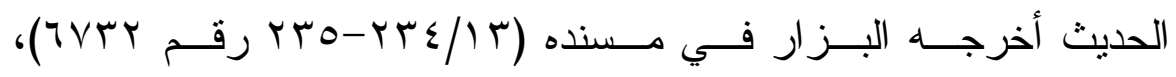

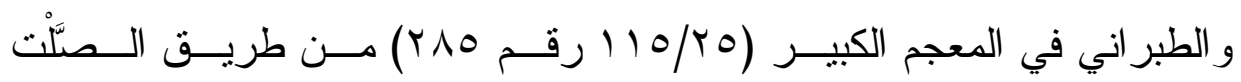

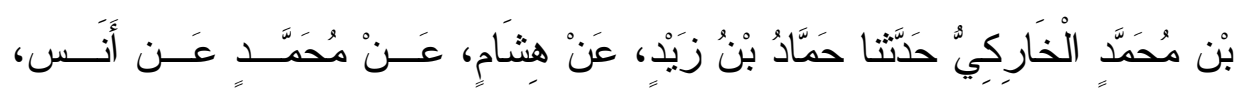

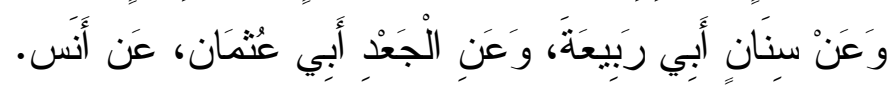

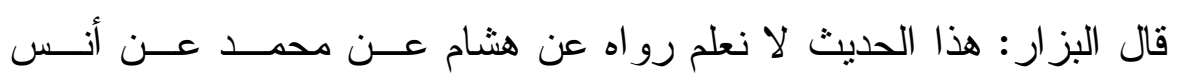
إلا حماد بن زيد.

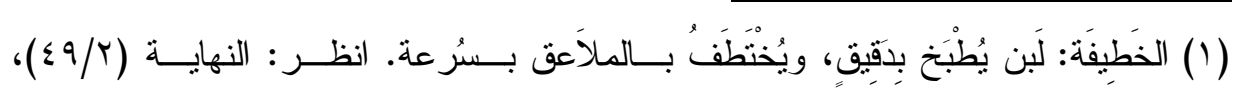
القاموس المحيط: باب الفاء، فصل الخاء (ب/ 19/1). 
والحديث أخرجه البُخاري: كتاب الأطعمة، بــاب مــن أدخـل الــضيفان

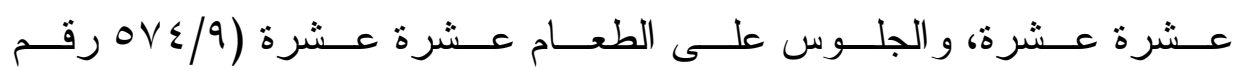

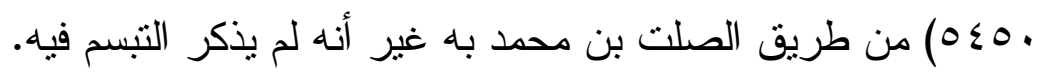

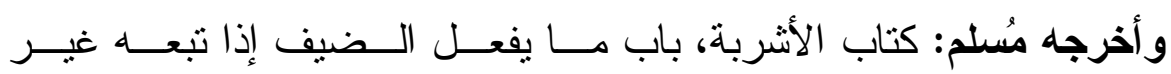

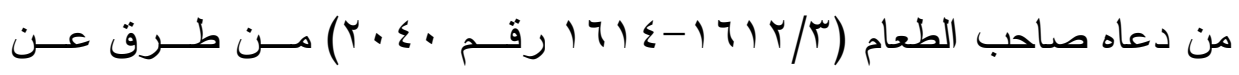

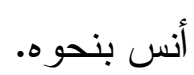




\section{المبحث الحادي عثَر}

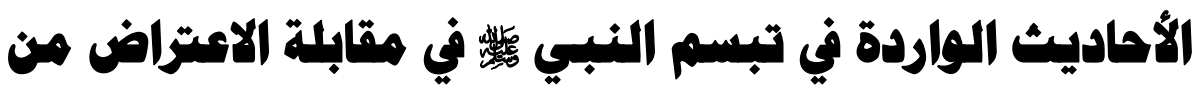 بمض أصمابه أو الإساءة من بمض الأعراب}

عَد

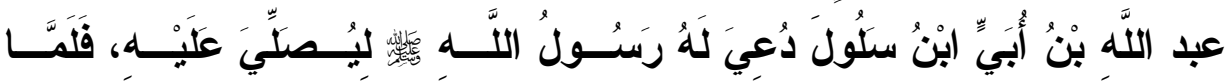

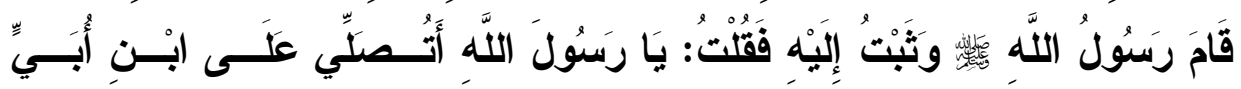

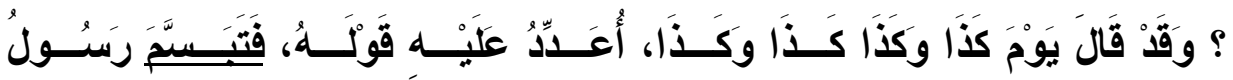

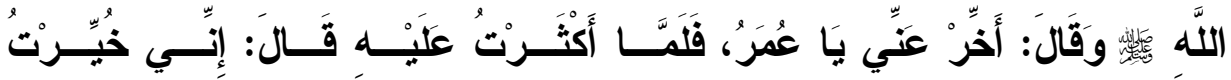

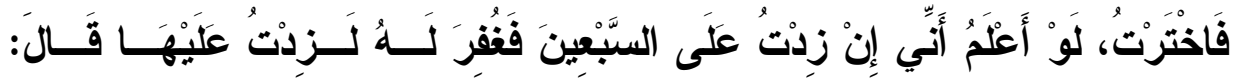

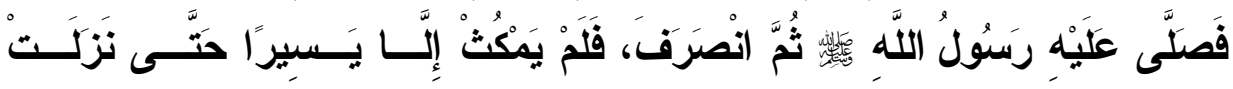

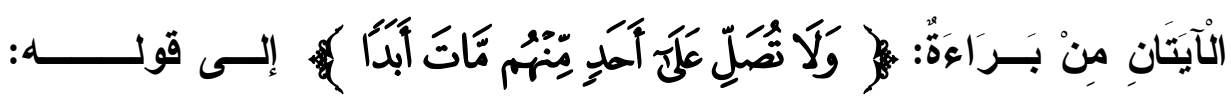

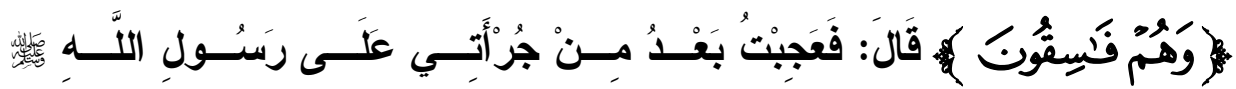

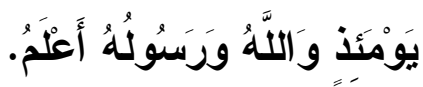

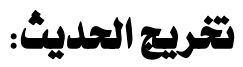

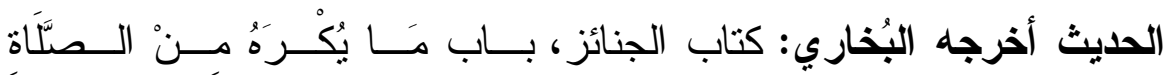

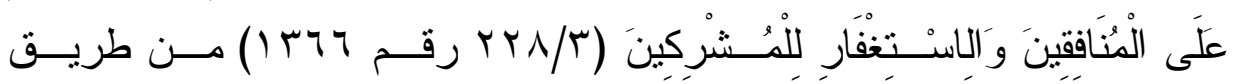
ابن شهاب عن عبيد الله بن عبداله عن ابن عباس عن عمر مَّبه..

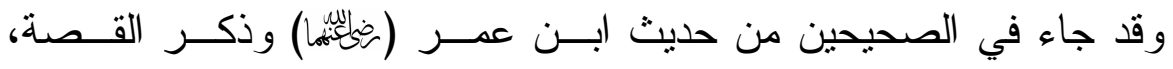

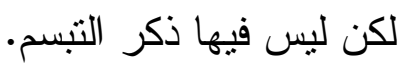




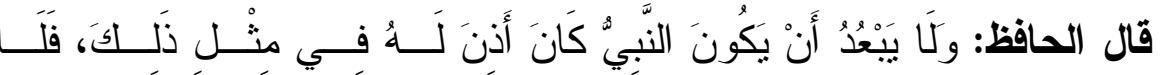

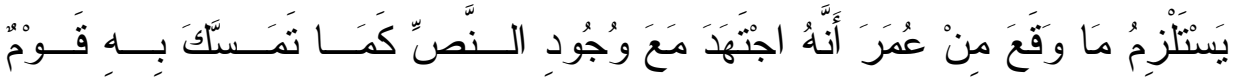

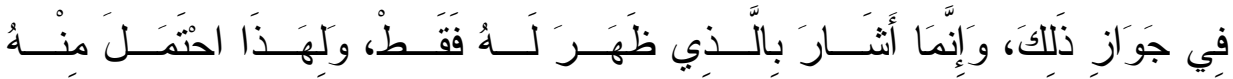

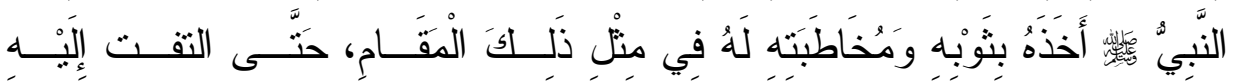

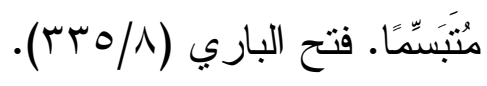

كَانَ

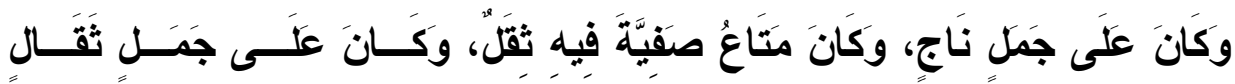

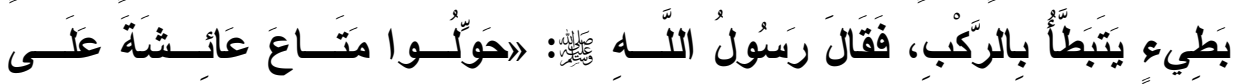

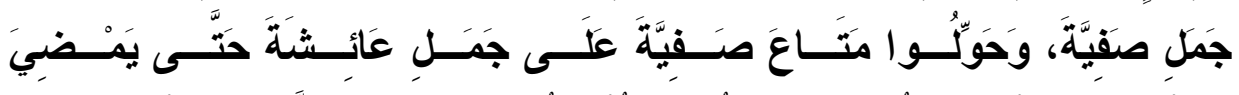

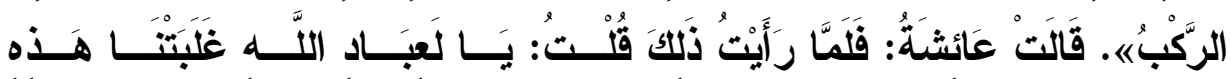

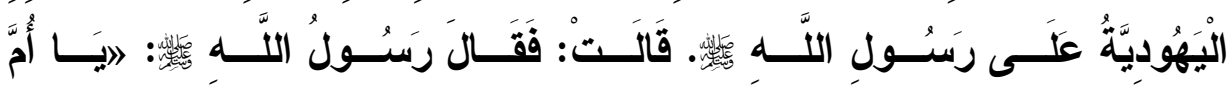

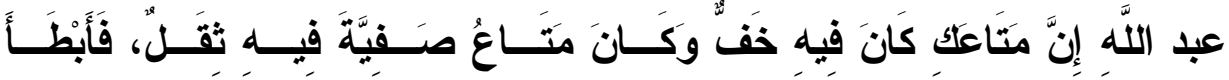

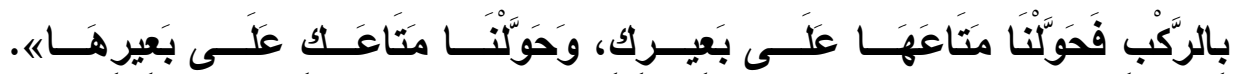

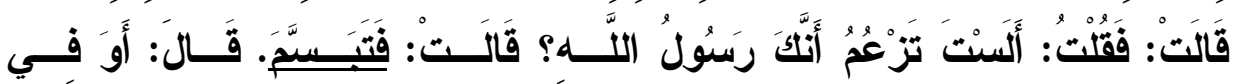

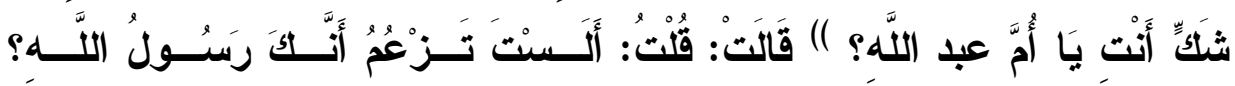

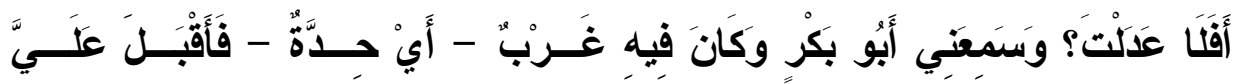

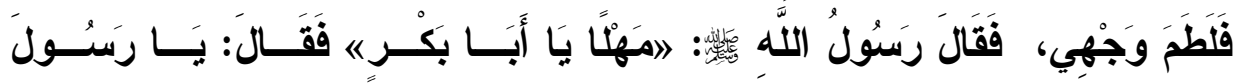

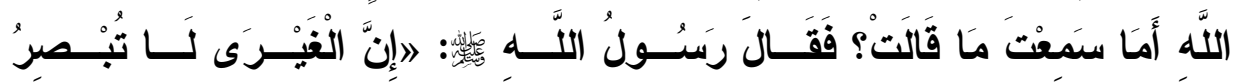

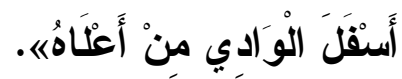

\section{تخريج الحديث:}

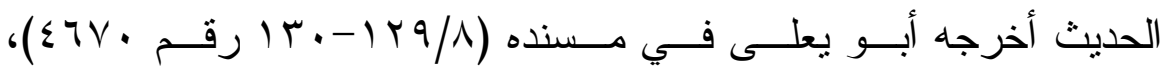

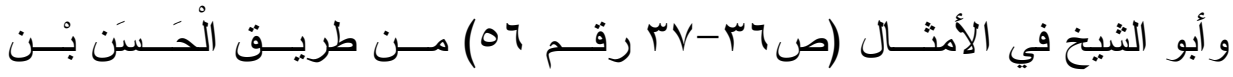




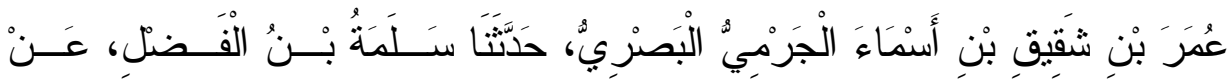

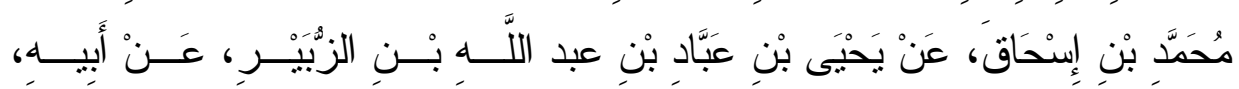
عَنْ عَائشَةَة. وعزاه الحافظ ابن حجر لأبي يعلى وقال: (( بـسند لا بــأس بــهـ ).فــتح

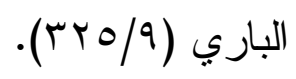

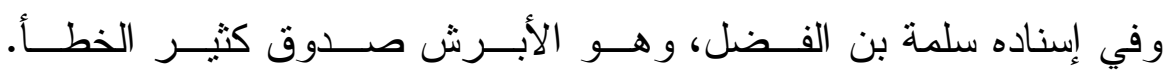

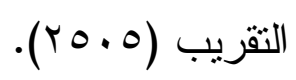

وكذلك فيه ابن إسحاق صدوق مدلس، وقد عنعن هنا.

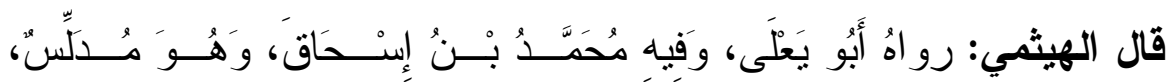

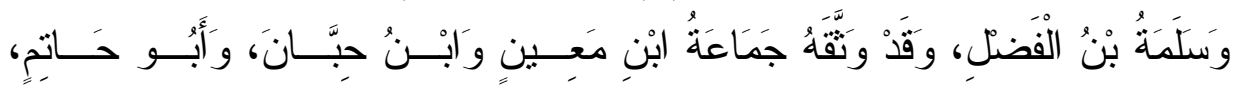

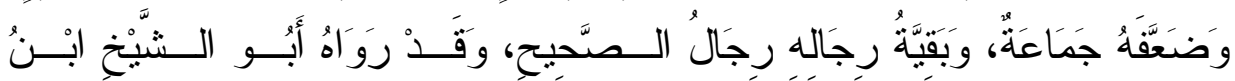

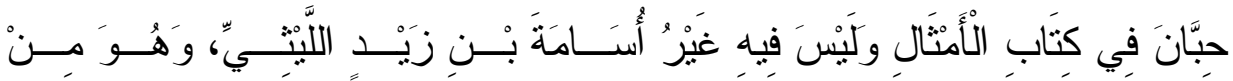

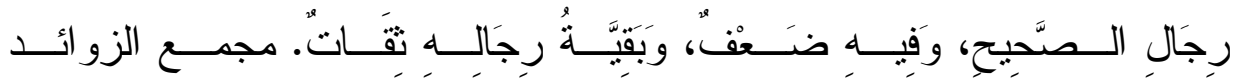
$\cdot(r+r / \varepsilon)$

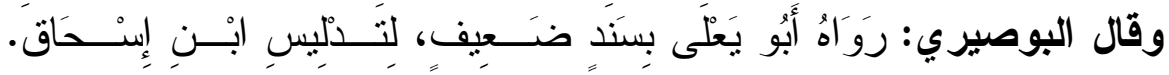

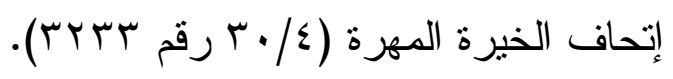

وكلام الهيثمي في ذكر رواية أبي الثيخ هكــذا ورد فـي نـسخة مجمــع

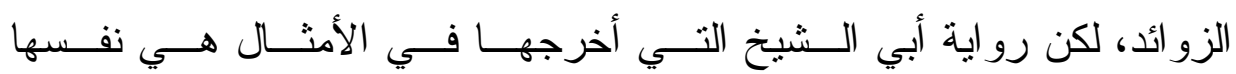
رواية أبي يعلى كما سبق.

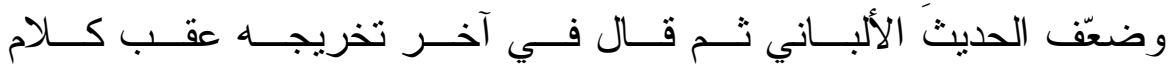

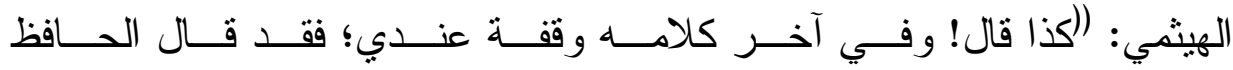
العر اقي في تخريج الإحياء (Y/ • ع): 
(رو اه أبو يعلى في مسنده و أبو الثيخ فــي كتــاب الأمثــال مــن حـديث عائشة، وفيه ابن إسحاق؛ وقاه عنعنه). قلت: فهذا صريح في مخالفة ما ذكره الهيثمي.

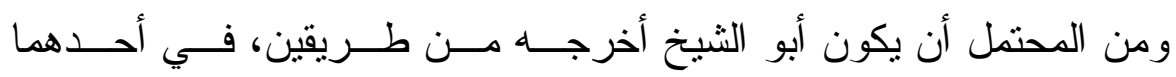

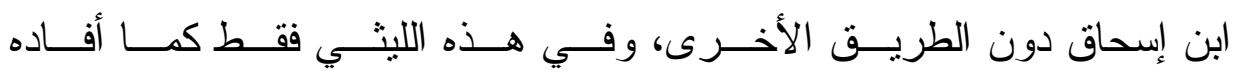

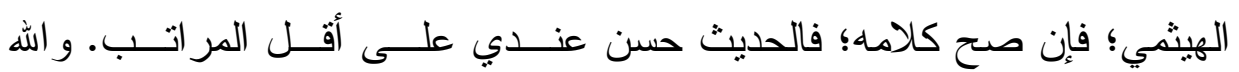

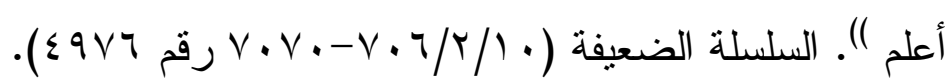

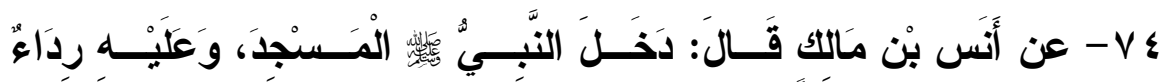

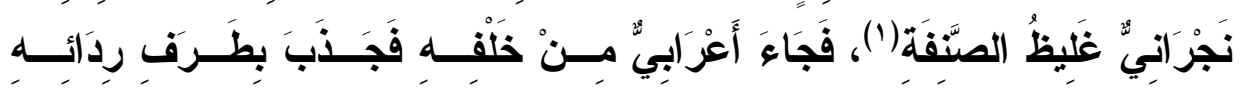

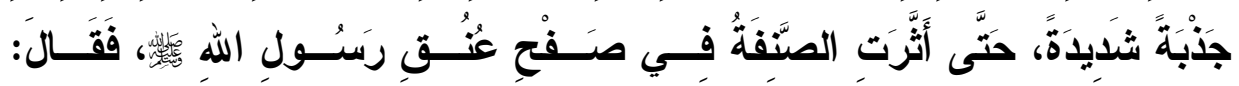

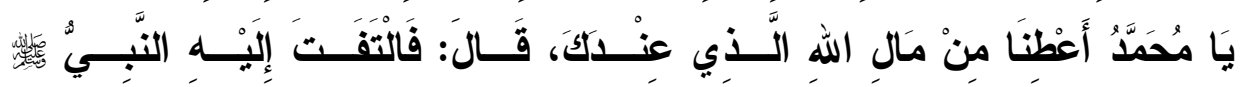

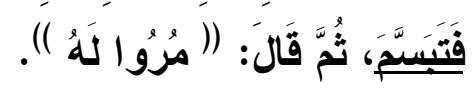

\section{تخريج الحديث:}

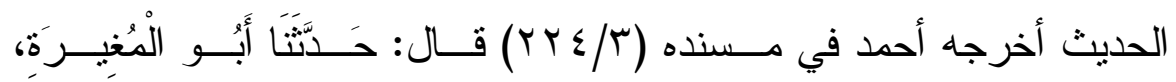

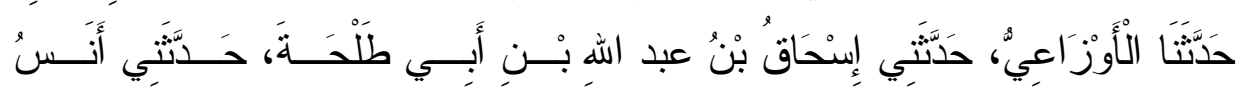
بْنْ مَاللكِ.

الصَّنَفَة: الجانب أبيَّ جانب كان. القــاموس المحــبط: بــاب الفــاء، فـــل الـــــاد $\cdot(r \mu N / T)$ 


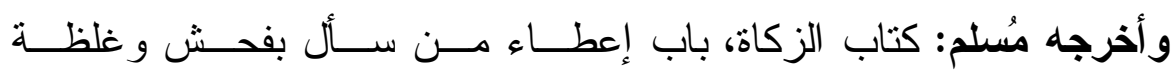

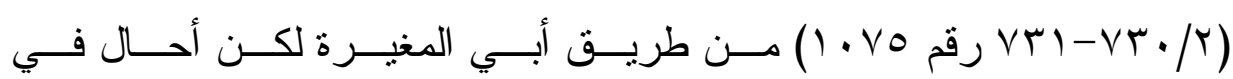
المنت على حديث قبله، وفيه: ((فالتقت إليه فضحك، ثم أمر له بعطاء )")

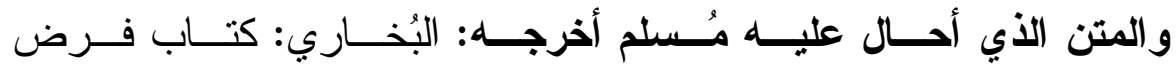

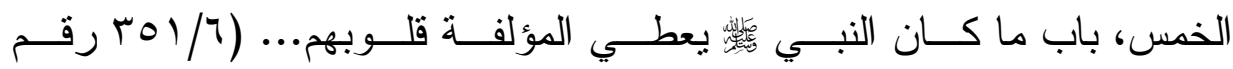

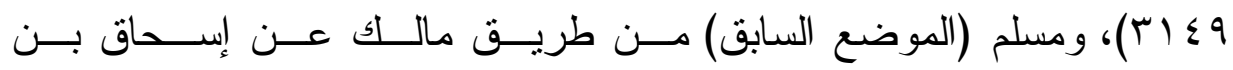
عبد الله بن أبي طلحة عن أنس بن مالك به.

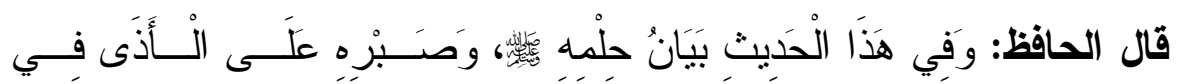

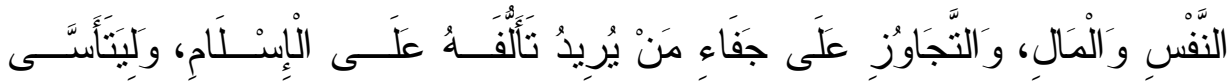

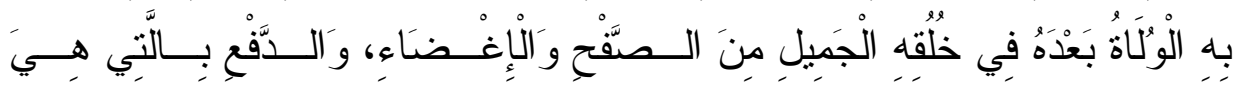

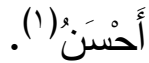




\section{المبحث الثاني عشار}

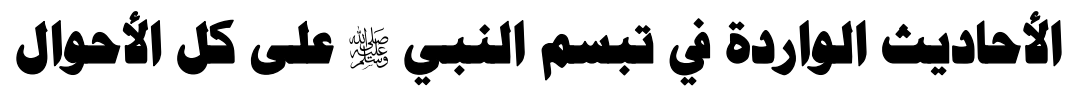

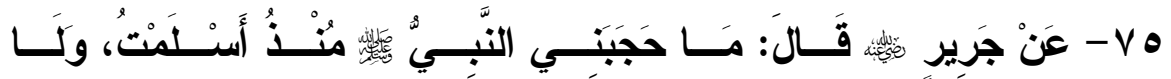

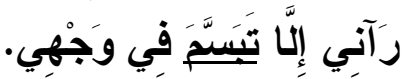

\section{تخريج الحديث:}

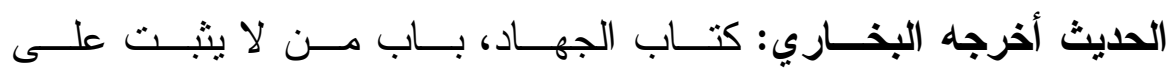

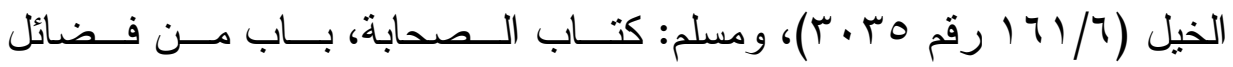

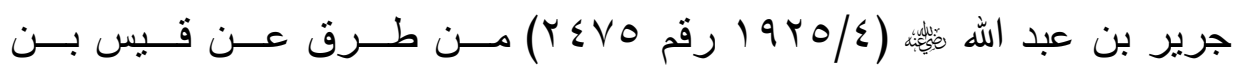
أبي حازم عن جرير، وفي رواية في الصحيحين: ((إلا ضحك )").

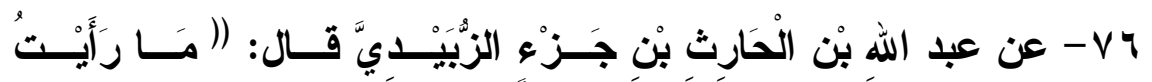

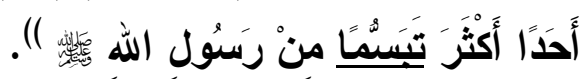

\section{تخريج الحديث:}

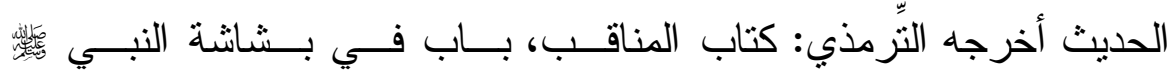

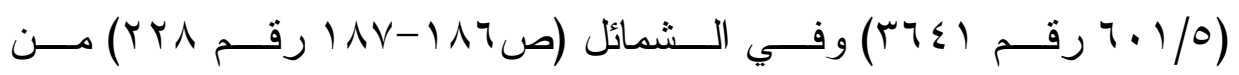

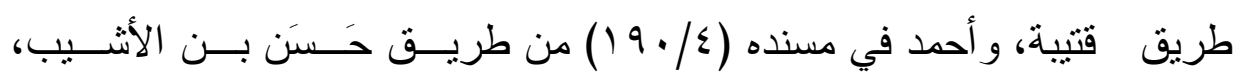

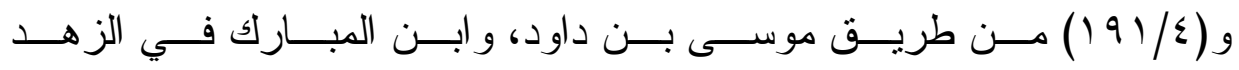

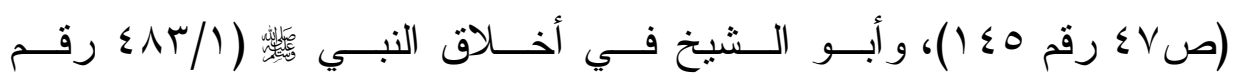

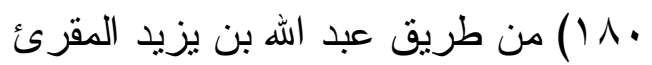

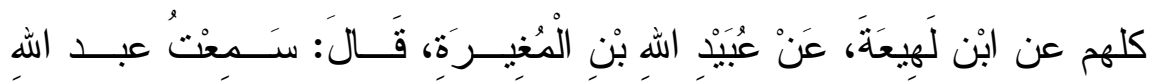

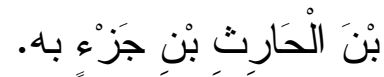




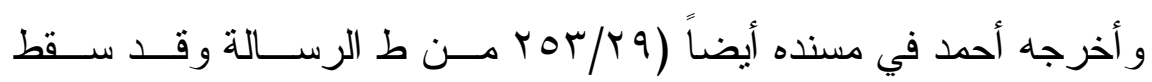

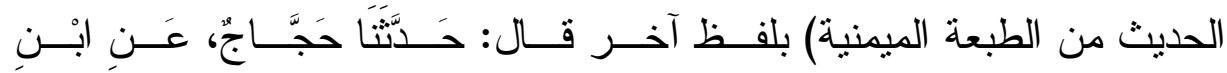

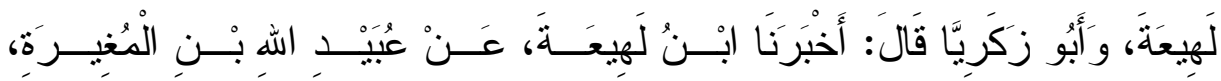

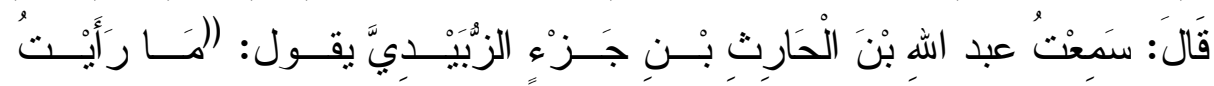
رَسُول اللهِ

و الحديث في إسناده ابن لهيعة: صــدوق، خلــط بعــد احتــراق كتبـــه،

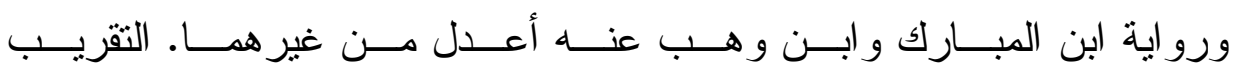

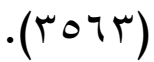

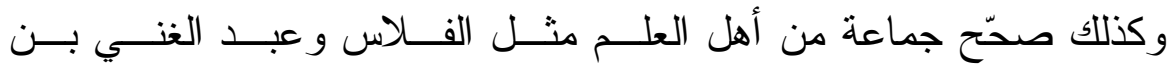
سعيد وابن حبان رواية المقـربي عنــهـ. انظـــر : ملحــق الكو اكــبـ النيــرات

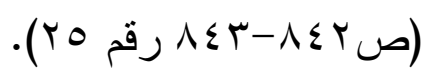

وقد روى هذا الحديث عن ابـن لهيعــة ابــنُ المبــارك و المقــرئ كمـــا سلف في تخريج الحديث. قال التّرمذي في جامعه: هذا حديث حسن غريب.

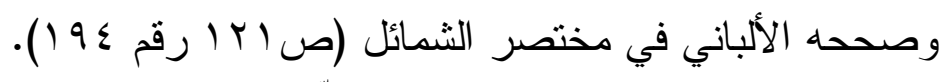

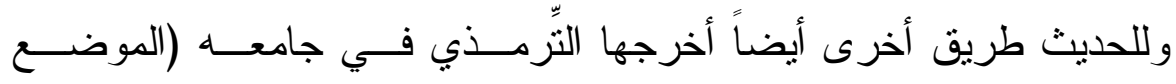

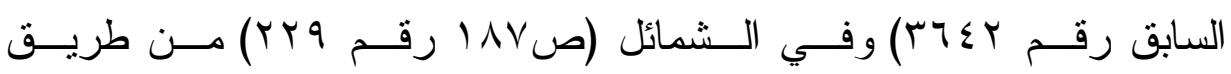

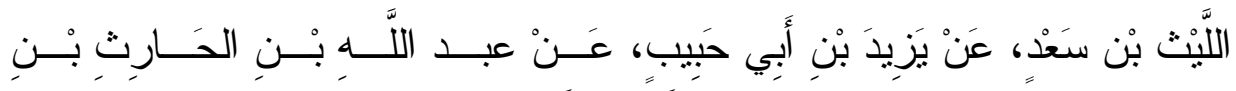

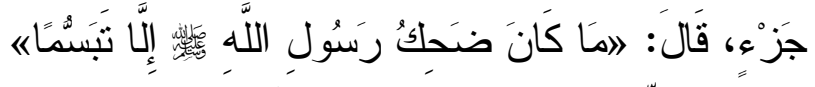

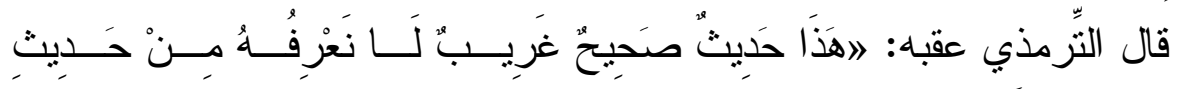

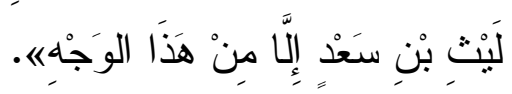
وصححه الألباني في مختصر الثمائل (الموضع السابق). 


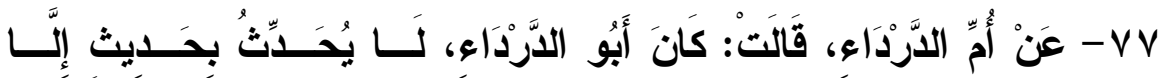

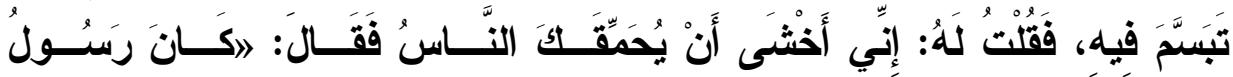

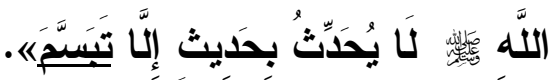

\section{تثريج الحديث:}

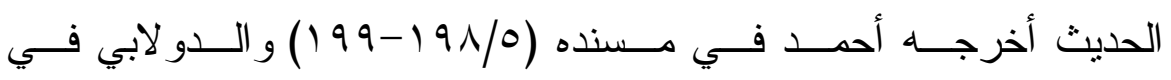
الكنى (1/1 • r رقم

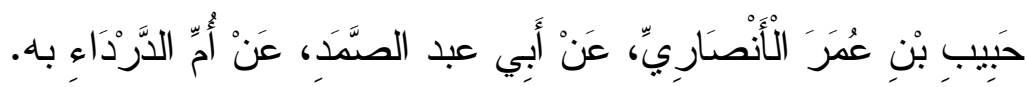

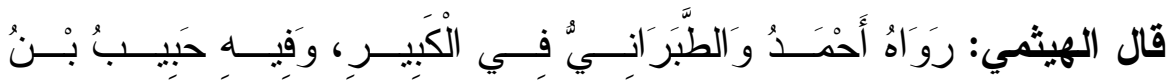

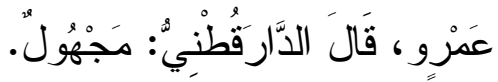

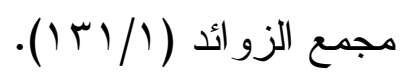

وفي إسنـاده: أبو عبد الصمد: مجهول، وذكره ابـن حبــان فـي التقــات.

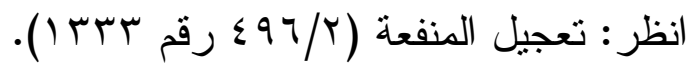

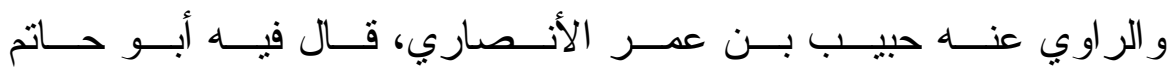

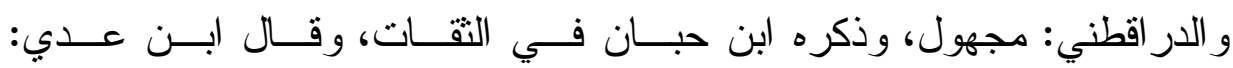

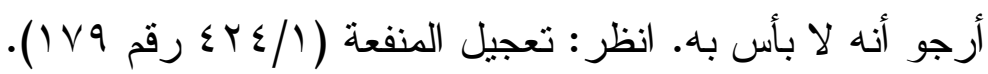
وفيه أيضا عنعنة بقية، وهو ممن يدلس تدليس التسوية. قال الألباني: هذا إسناد ضعيف؛ أبو عبــد الــصمد وحبيـبـ بـن عمــر الأنصاري؛ مجهو لان. وبقية؛ مدلس وقد عنعنه. السلسلة الضعيفة (q (

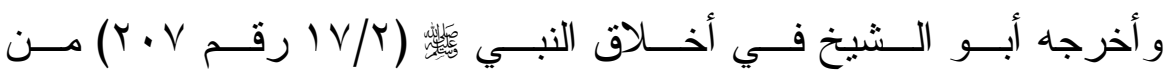

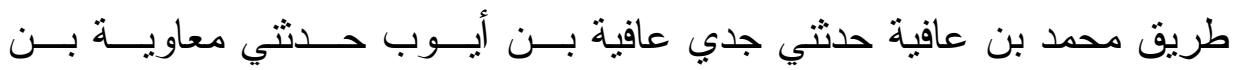


صالح حدثني عبد الرحمن بن ميسرة عـن أم الــدرداء عـن أبــي الــدرداء، فذكره و اقتصر فيه على المرفوع.

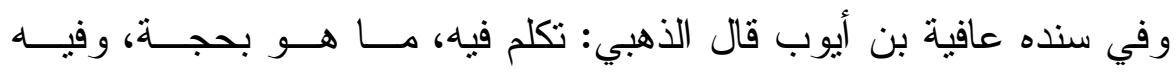

جهالة.

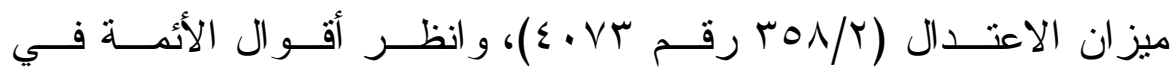

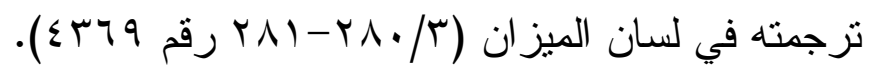
و ابنه محمد لم أقف على تزجمته.

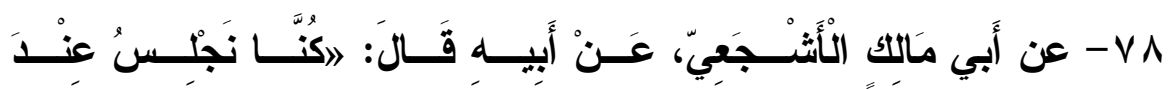

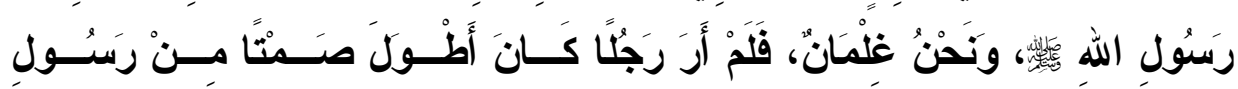
اللهِ

\section{تخريج الحديث:}

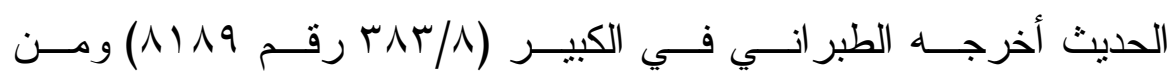

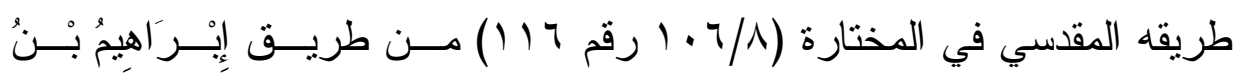

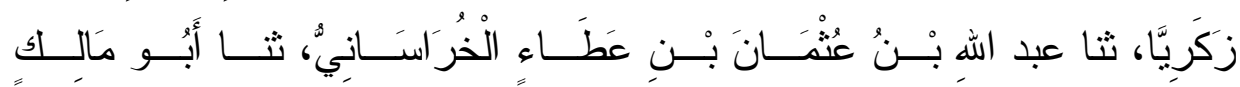

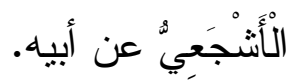

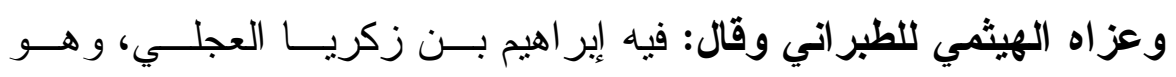

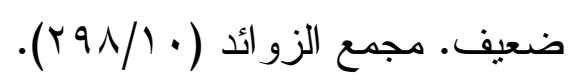

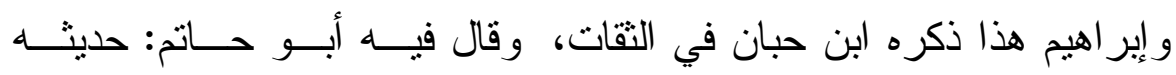
منكر ، وقال ابن عدي: حدث بالبو اطيل.

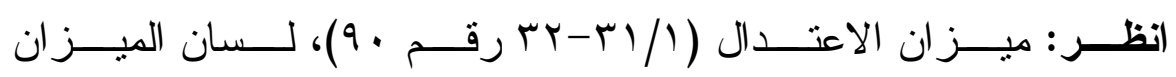

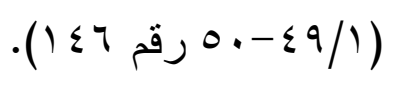




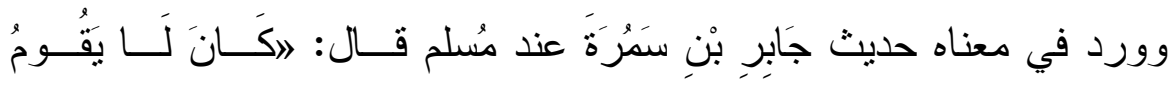

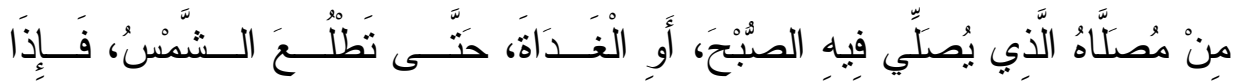

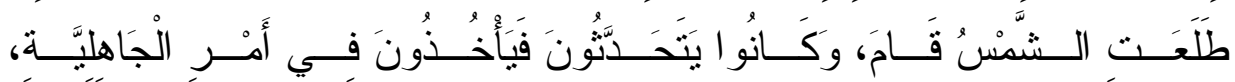

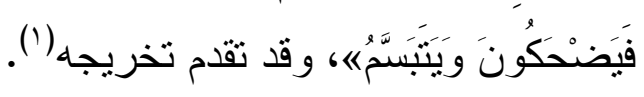




\section{الهبحث الثالث عشر}

الأحاديث الواردة في كيفية تبسمه

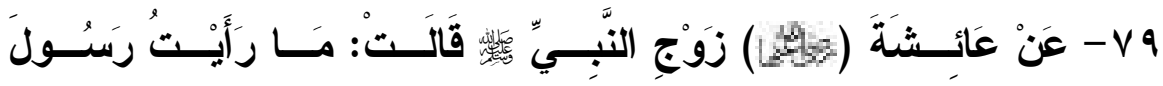

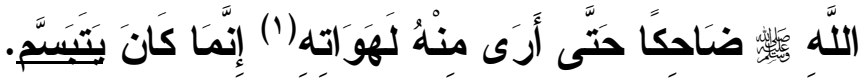

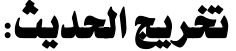

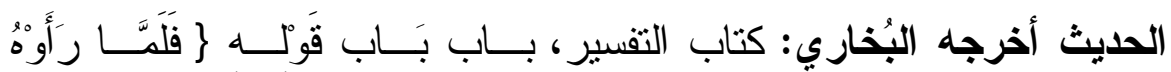

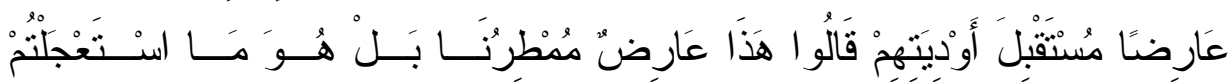

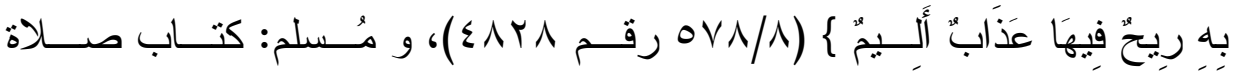

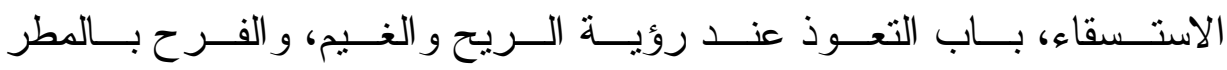

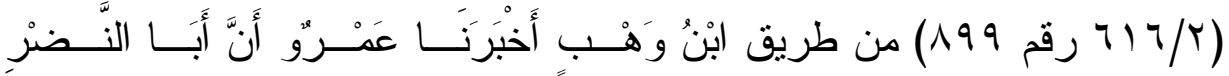

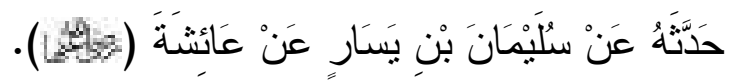

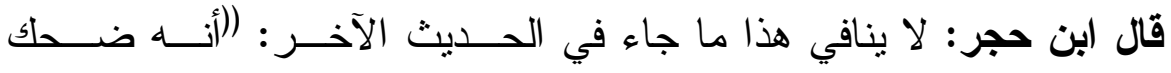

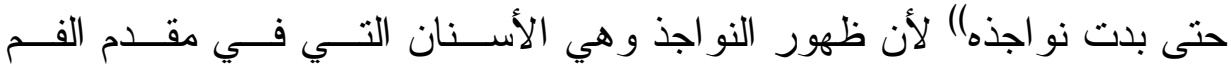
أو الأنياب لا يستلزم ظهور اللهاة(؟).

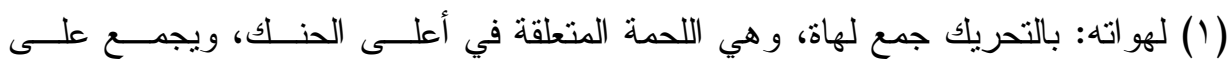

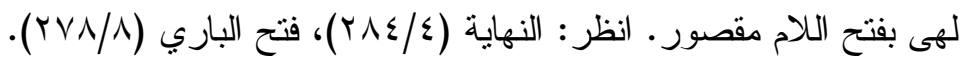

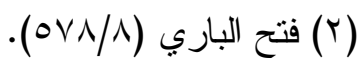




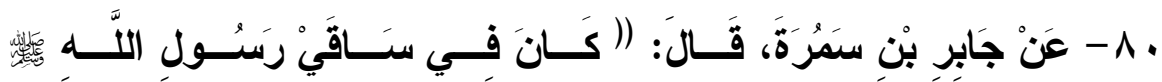

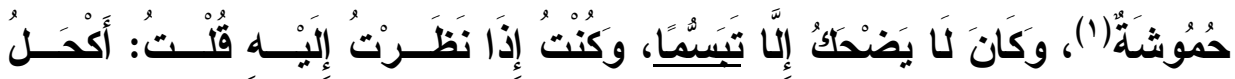

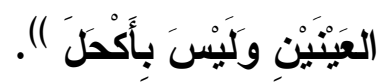

\section{تخريج الحديث:}

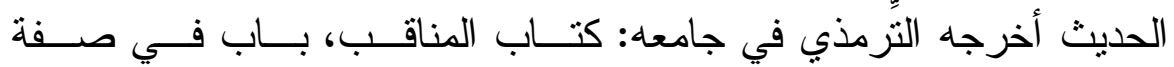

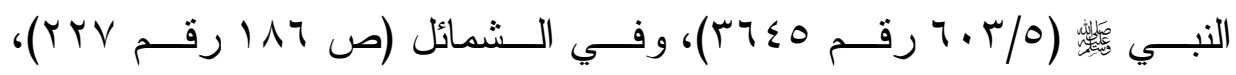

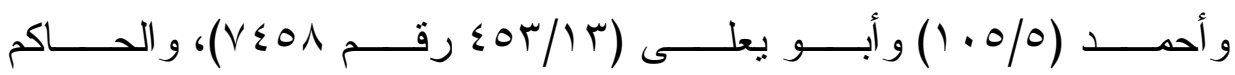

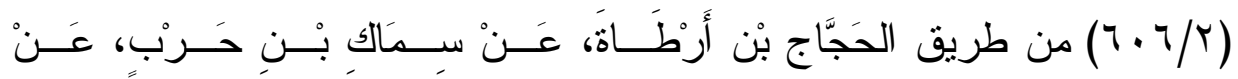
جَابر بْنَ سَرْرَةً

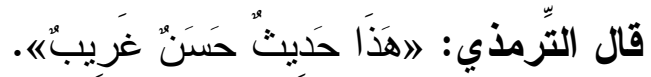
وقال الحاكم: هذا حديث صحيح الإسناد ولم يخرجاه. وتعقبه الأهبي فقال: قلت: حجاج لين الحديث.

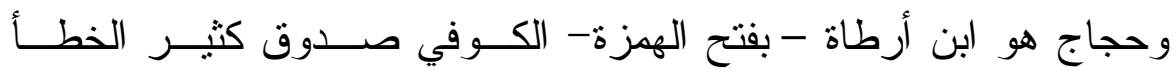

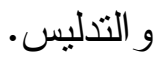
وقد دلّس هنا.

وقال الألباني في مختصر الشمائل (ص • r ا رقم ب 9 ( )): ضعيف.

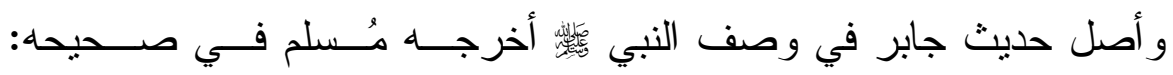

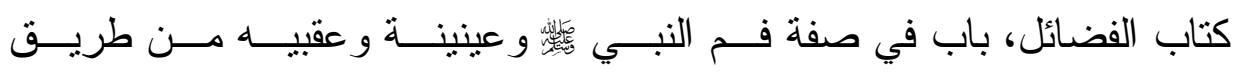

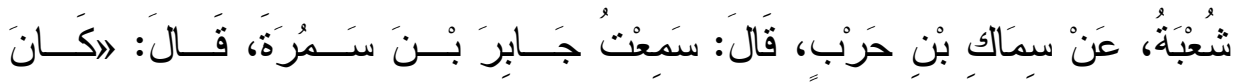

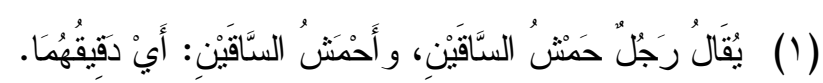

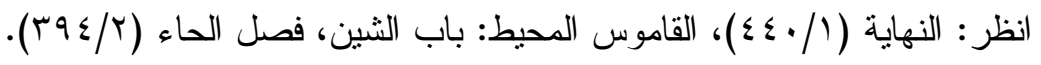




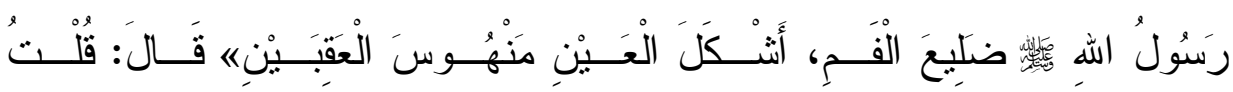

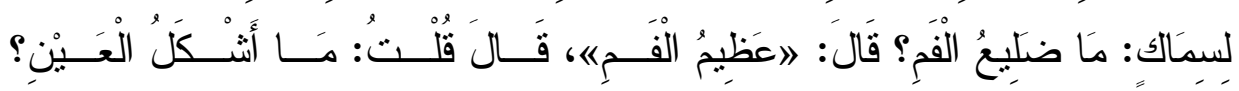

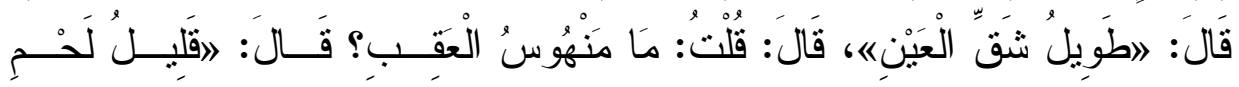

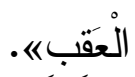

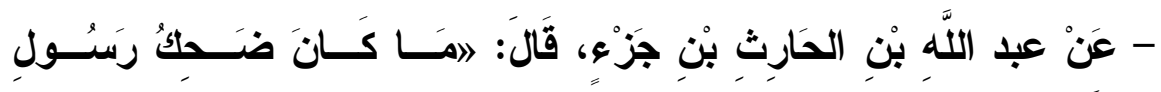
اللَّلَه

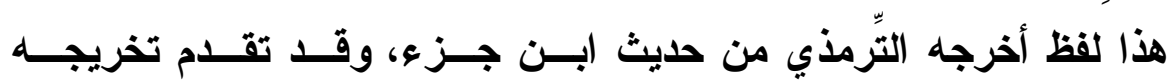

في المبحث الثاني عشر (').

فائدة:

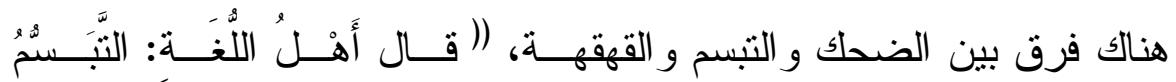

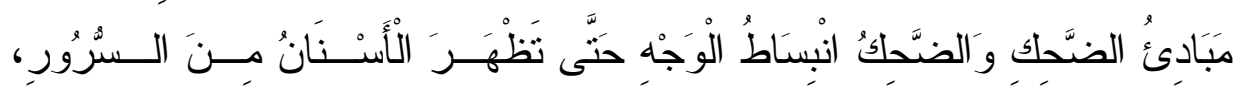

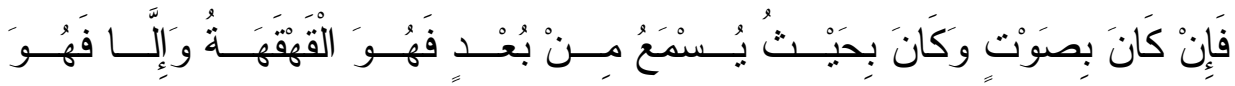

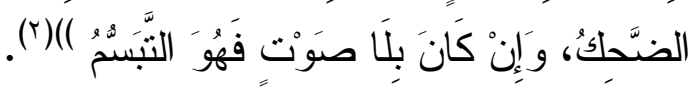

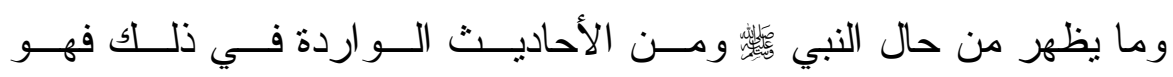

تبسمه

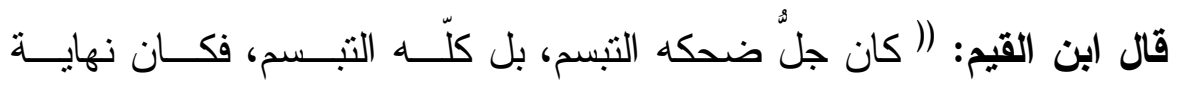
ضحكه أن تبدو نو اجذه.

وكان يضحك مما يضحك منه، وهو مما يتعجــب مــن منلـــه ويـستغرب

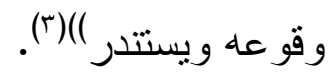

$$
\begin{aligned}
& \text { انظر : تخريج حديث رقم (VT). }
\end{aligned}
$$

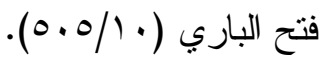

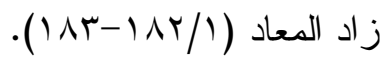




\section{الغنَانَّة}

الحمد لله الذي بنعمته تتم الصالحات، وبعد:

فهذه أهم النتائج التي وصلت إلبها في هذا البحث:

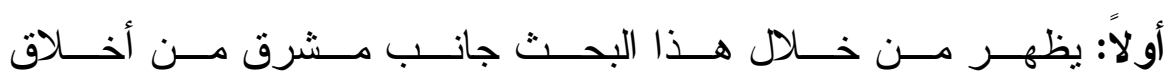

المصطفى

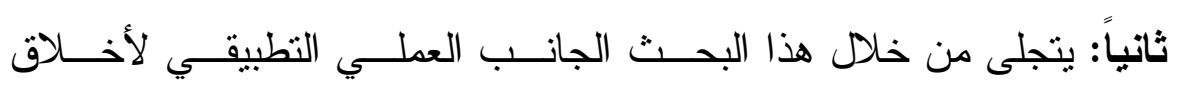

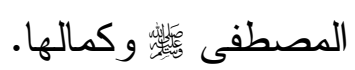

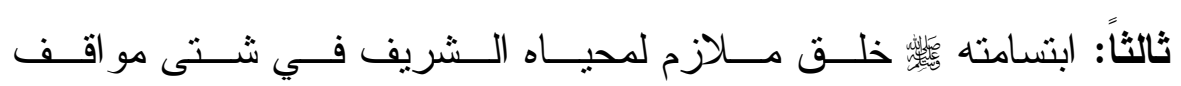

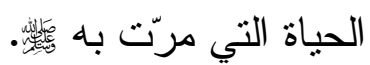

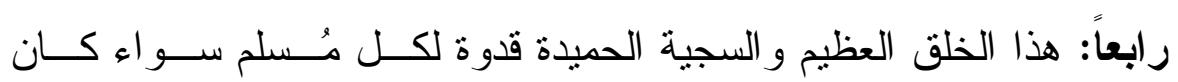

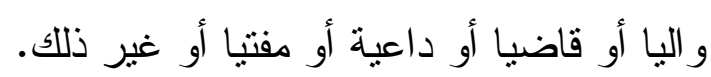

خامساً: الغالب على حال النبي لئي

(1) (1) ملحوظة: (1) (1)

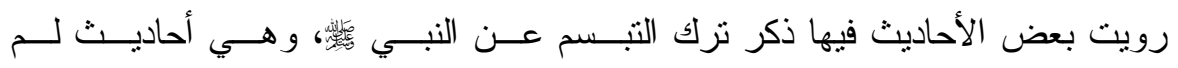

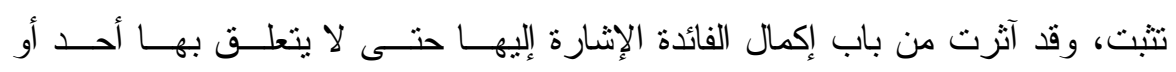

$$
\text { الحتج بها على عمل بر اه، وهي: }
$$

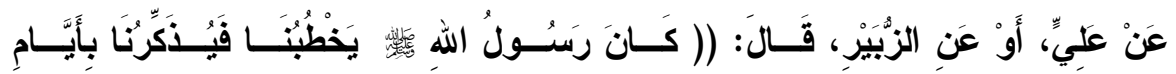

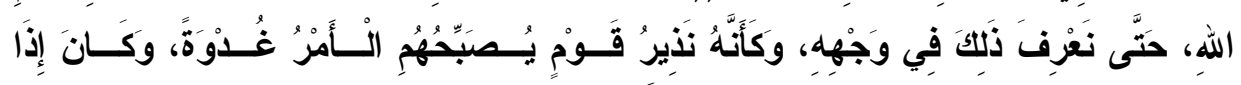

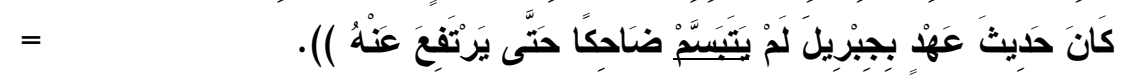




\section{= تخريج الحديث:}

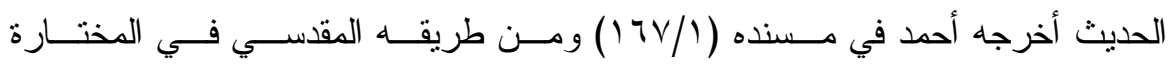

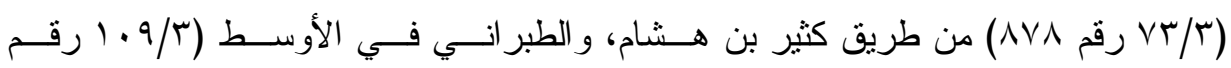

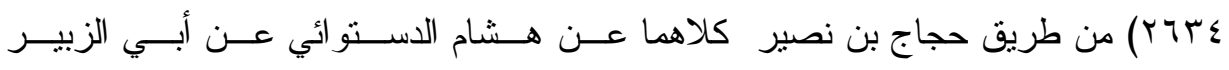

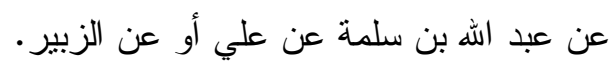

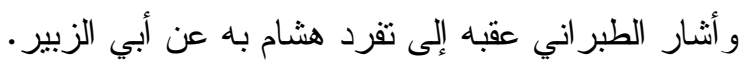

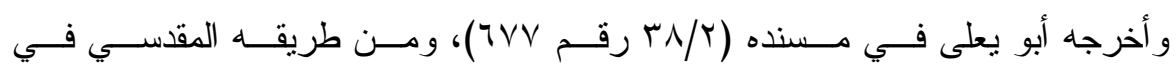

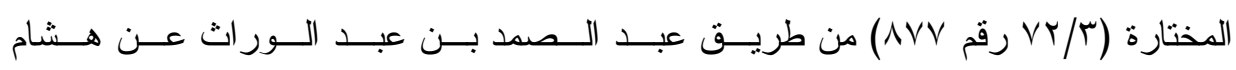
الدستو ائي به وقال فيه: عن الزبير وحده.

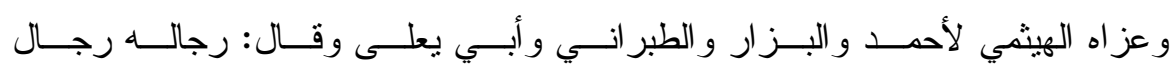

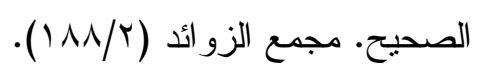

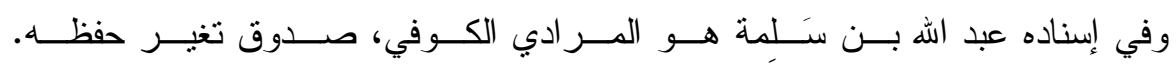

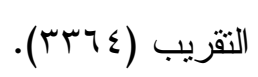

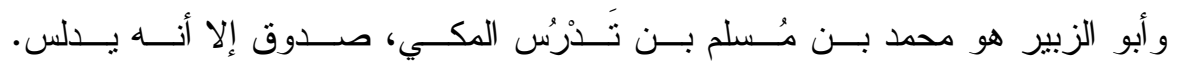

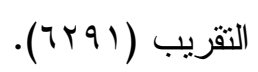

ورو ايته هنا عن عبد الله بن سلمة بالعنعنة، فالإسناد ضعيف.

\section{الحديث الثاني:}

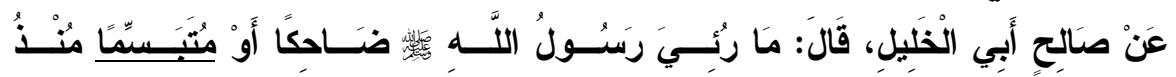

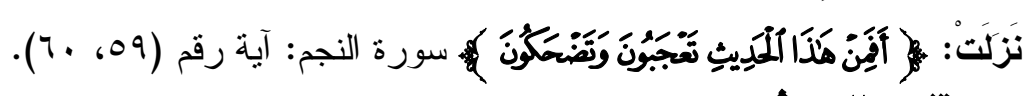
تخريج الحديث:

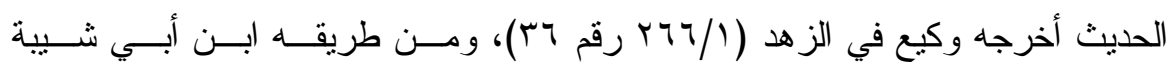

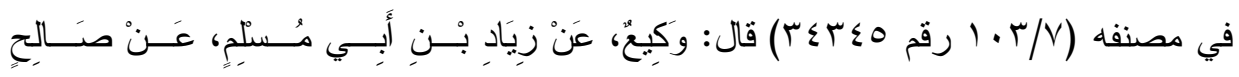
أَبِي الْخلِيلِ.

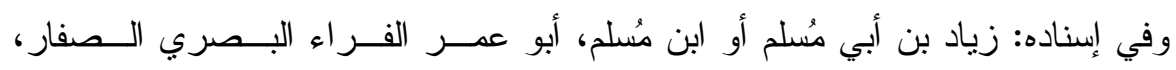

$$
\begin{aligned}
& = \\
& \text { صدوق فيه لين. الثقريب ( . (r). }
\end{aligned}
$$




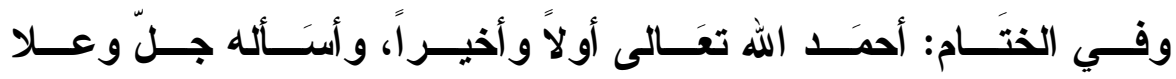

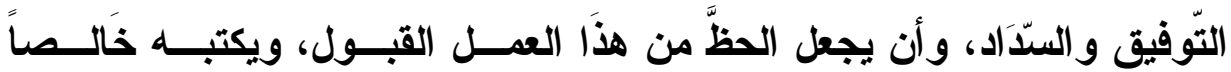

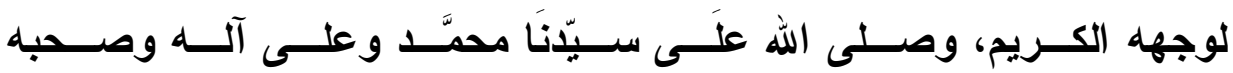
أجمعين، والحمد الله رب العَالمين.

$=$

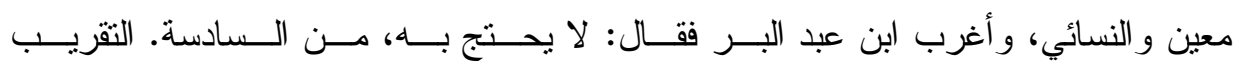
.$(Y \wedge \wedge \vee)$

و الخبر ضعيف لعدم اتصاله، ومتته فيه نكــــارة ومخالفـــة لــسائر الأحاديــث الـــواردة

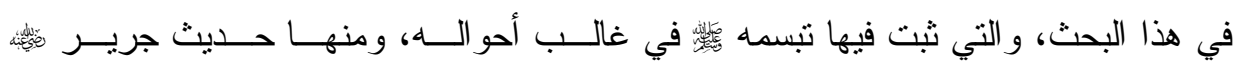

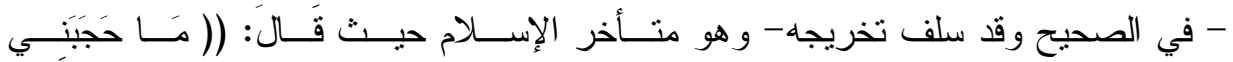

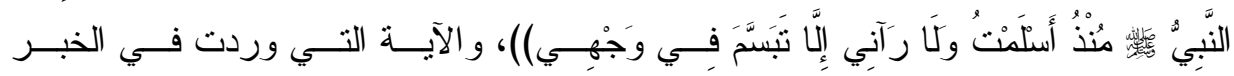

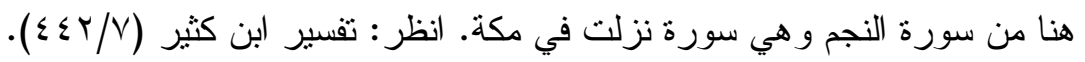

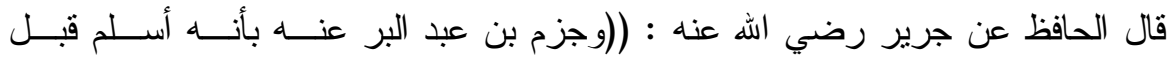
وفاة النبي

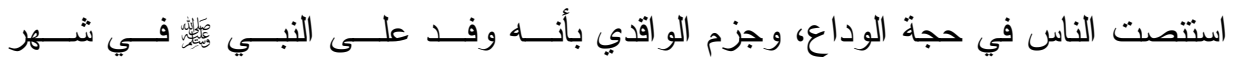

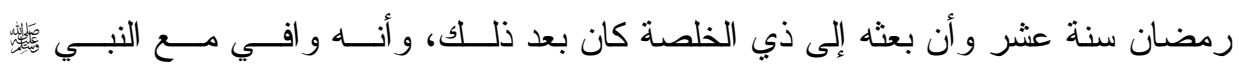

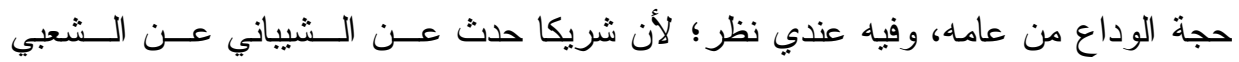

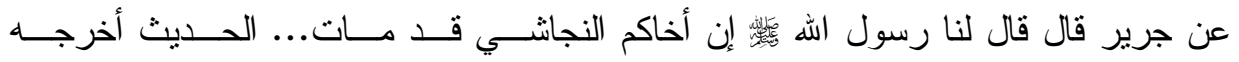

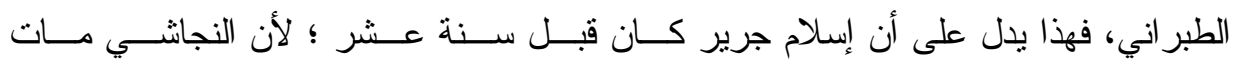

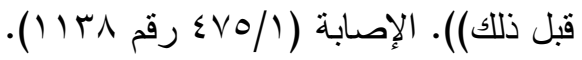




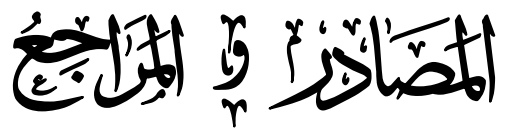

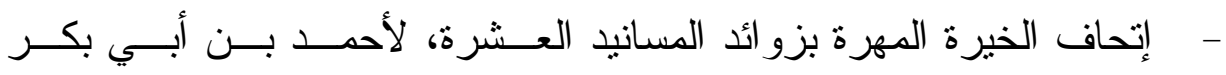

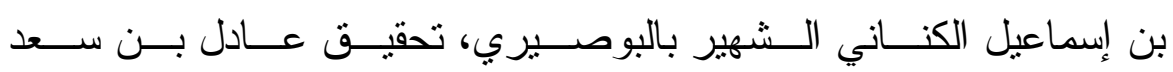

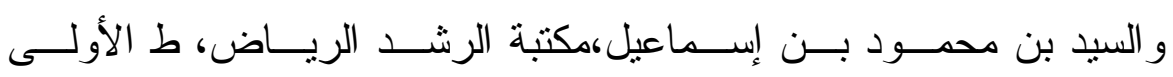
$\rightarrow 1519$

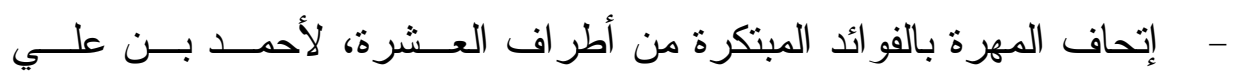
بن حجر العـسقلاني، تحقيـق زهيــر بــن ناصــر الناصــر و آخــرين،

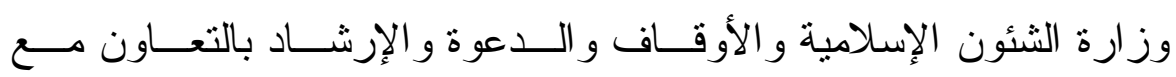
الجامعة الإسلامية، ط الأولى.

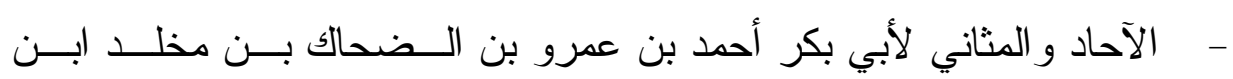

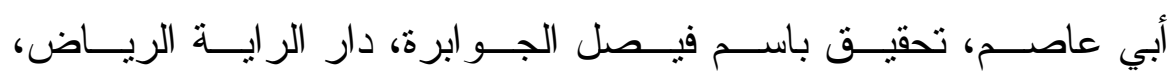

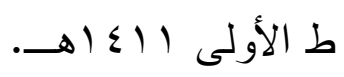

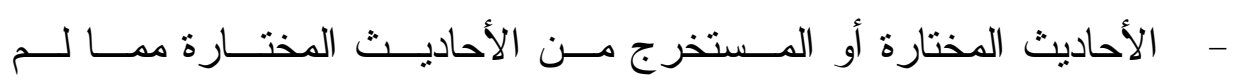
يخرجه البخاري ومسلم فـي صـــيحهما، لــضياء الــدين أبــي عبــــالله

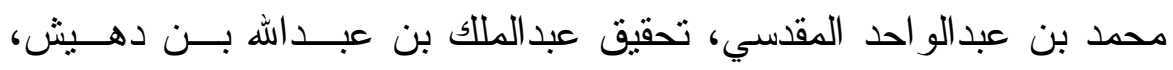

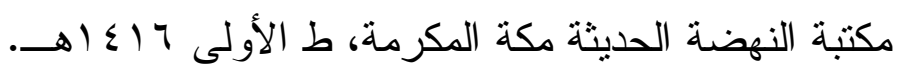

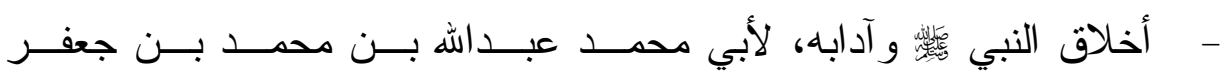

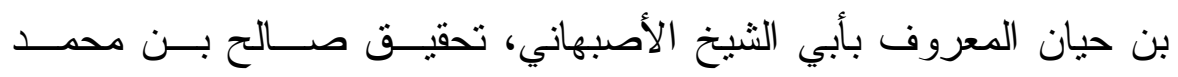

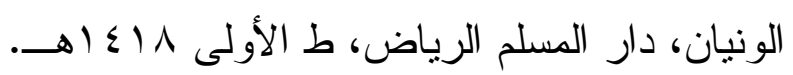

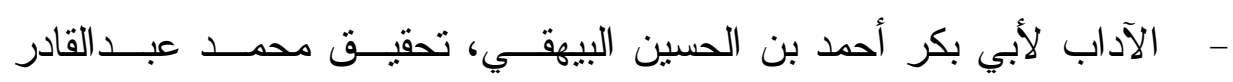

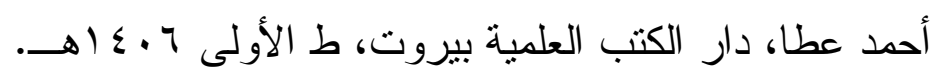


- - الأدب المفرد لمحمد بن إسماعيل البخــاري، تحقيــق ســمير بــن أمسـين

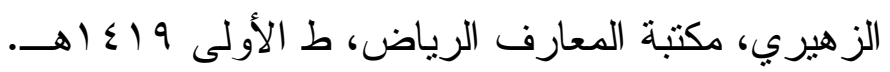

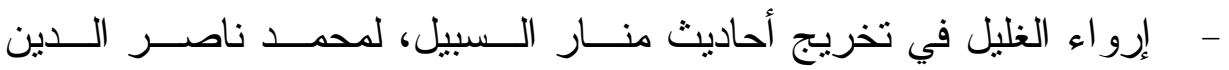

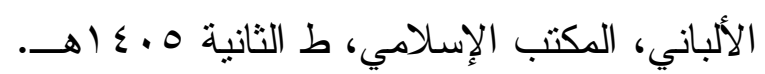

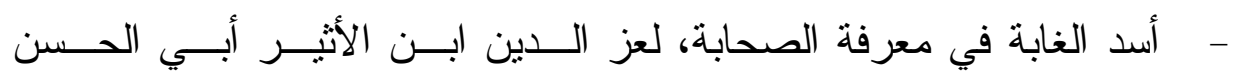

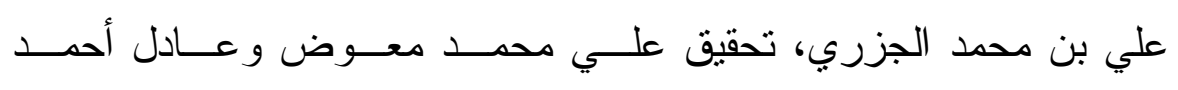

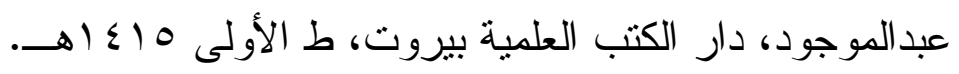

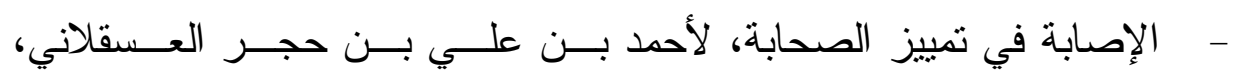

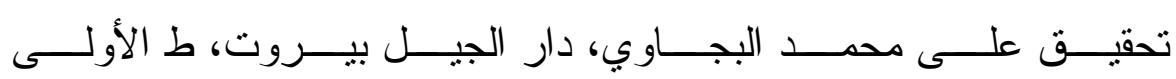
. - الإكمال في ذكر من له رواية في مـسند أحمــــ سـوى مــن ذكــر فـي تهذيب الكمال، لأبي المحاسن محمد بـن علـي بــن الحــسين الحــسيني،

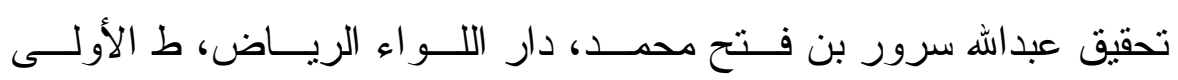

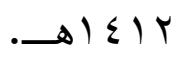

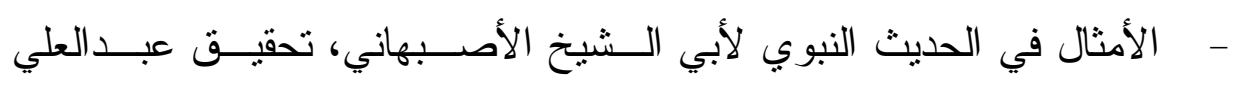

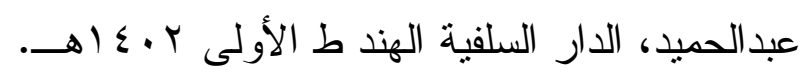

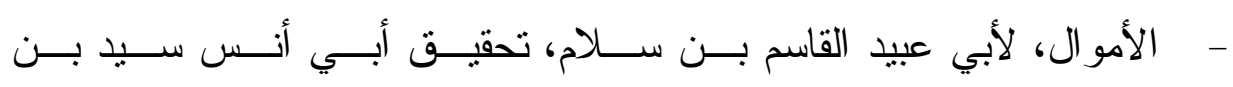

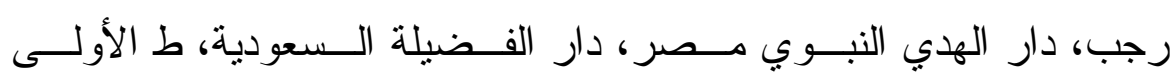
$\rightarrow 1 \leqslant r \wedge$

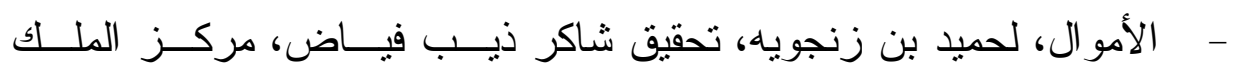
فيصل للبحوث و الدر اسات الإسلامية. 
- - البحر الزخار المعروف بمسند البزار، لأبــي بكـر أحمـــــــن عمــرو بن عبدالخالق البزار، تحقيق محفوظ الــرحمن زيــن الله، مكتبــة العلـــوم

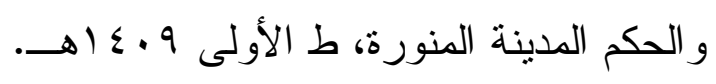

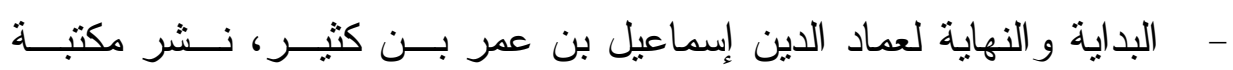

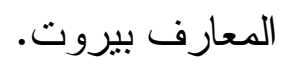

- - تاريخ الرسل و الملوك، لأبي جعفر محمد بـن جريــر الطبــري، تحقيـق

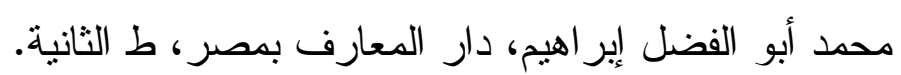
- - تاريخ الطبري = تاريخ الرسل و الملوك. - - التاريخ الكبير، لأبي عبداله محمد بــن إبــماعيل البخــاري، نـشر دار

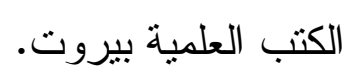

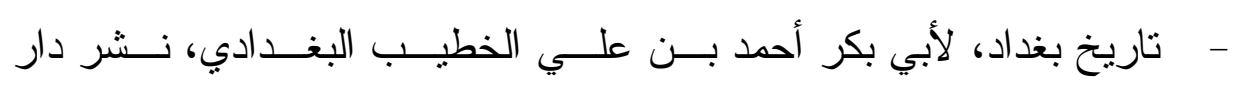

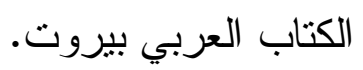

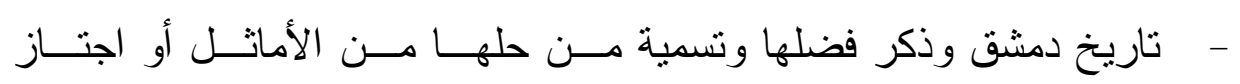

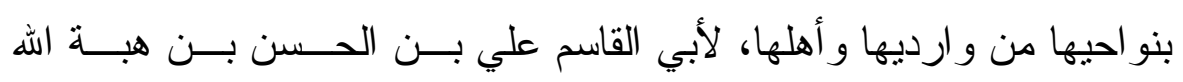

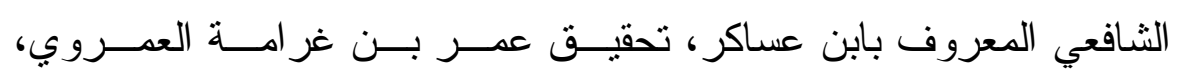

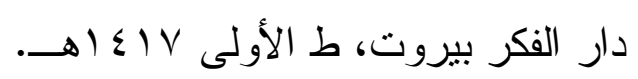
- تخريج الإحياء = المغني عن حمل الأسفار •

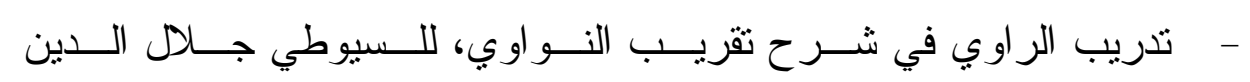

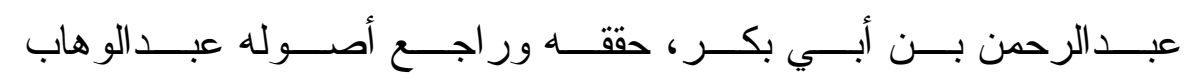

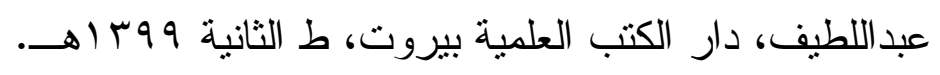




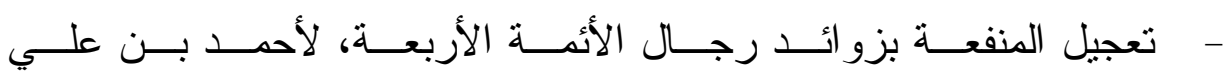

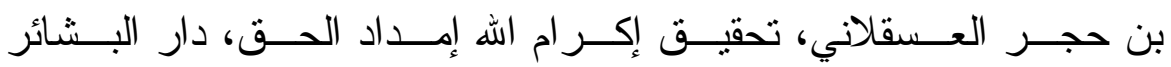

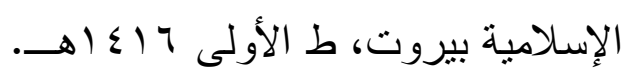

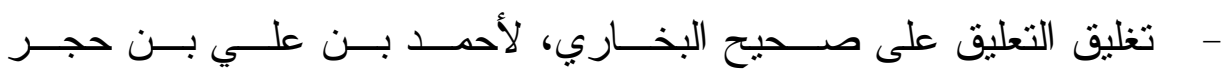

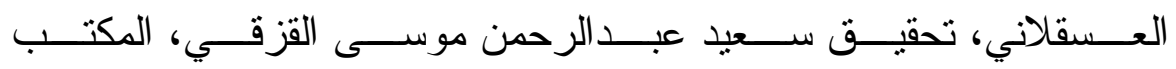

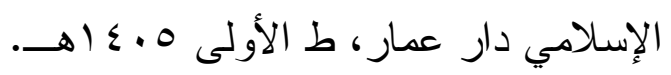
- تقسير القرآن العظيم، لأبي المؤلف: أبــو الفــداء إبــماعيل بــن عمــر

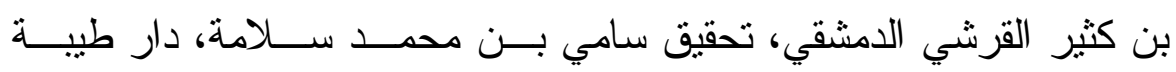

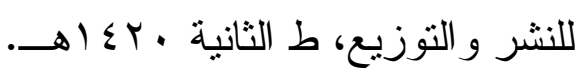
- تقريب التهذيب لثهاب الدين أحمد بـن علـي بـن حجــر العـسقلاني،

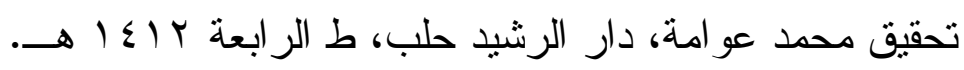

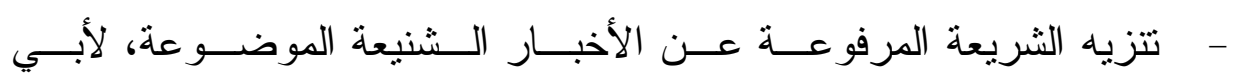

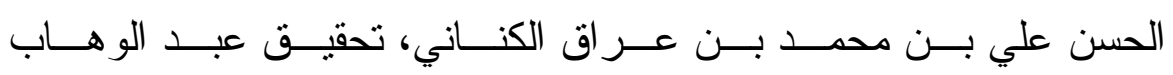

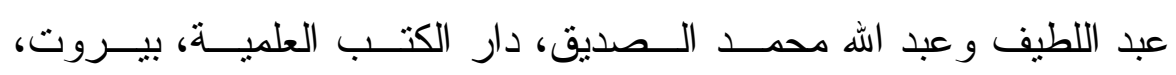

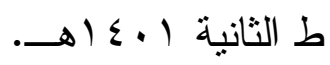

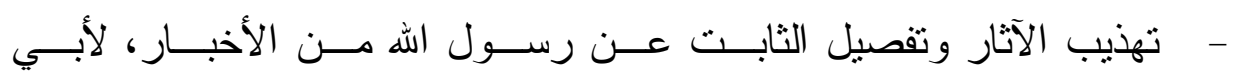

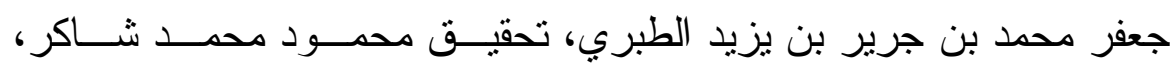
ط مطبعة المدني، القاهرة. - تهذيب التهذيب لأبي الفضل أحمـــــــن علـي بـن حجــر العـسقلاني،

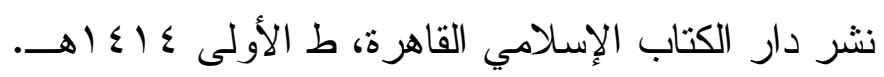




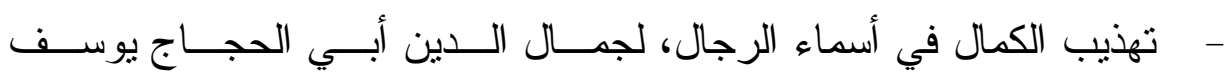

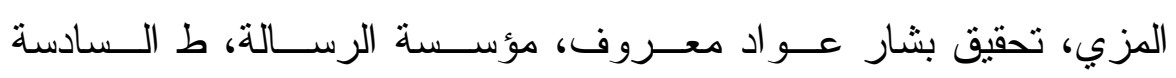
$\rightarrow 1 \leqslant 10$

- الثقات لهحد بن حبان البستي، مصورة عـن الطبعــة الأولـى بمطبعـة

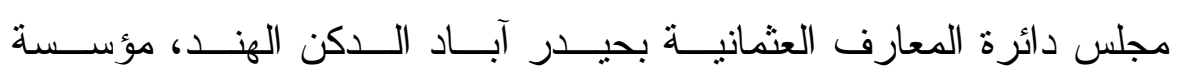

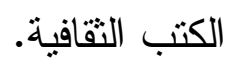

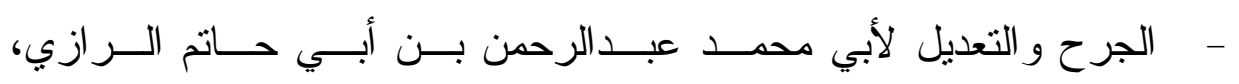

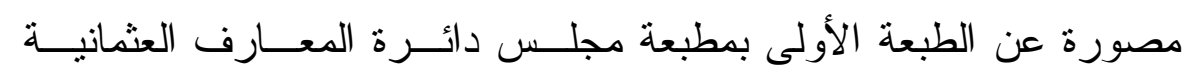

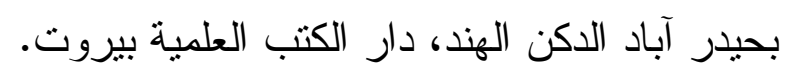

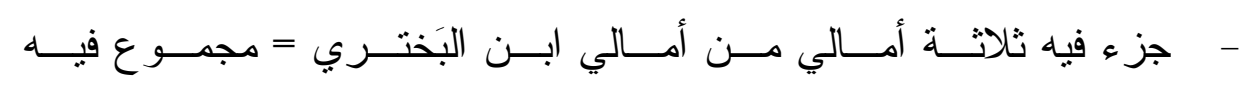
مصنفات أبي جعفر ابن البختري.

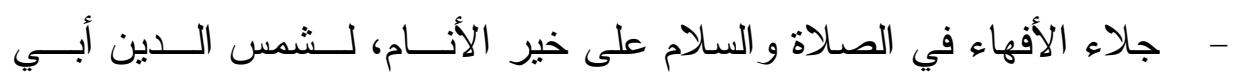

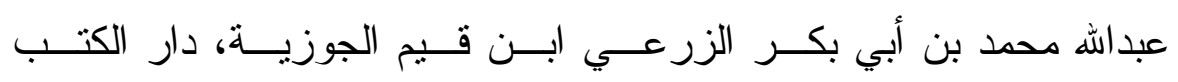

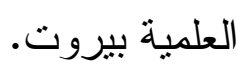

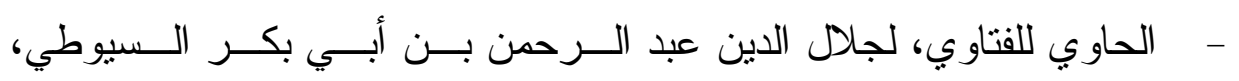

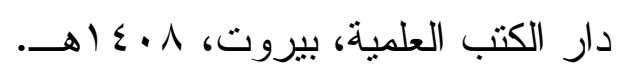

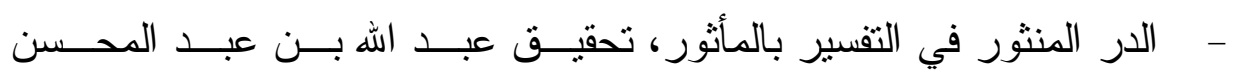

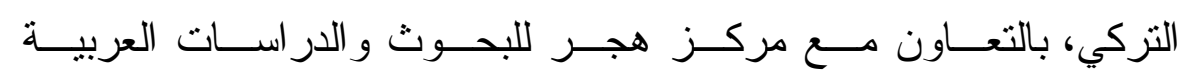

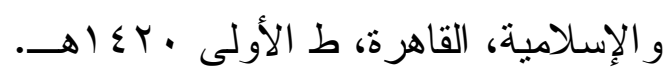

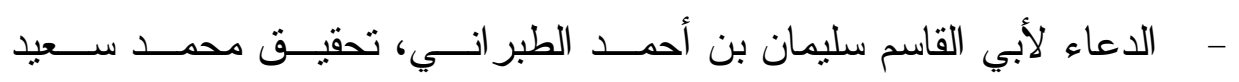

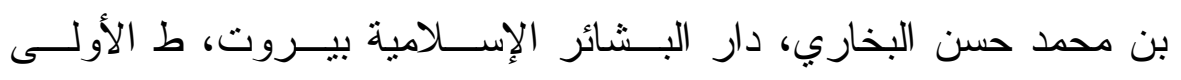
$\rightarrow$. $\rightarrow$. $V$ 


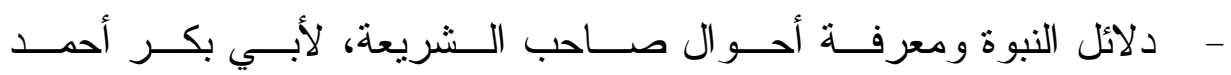

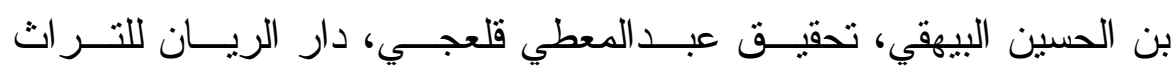

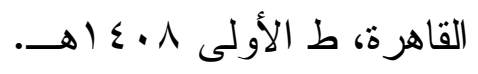

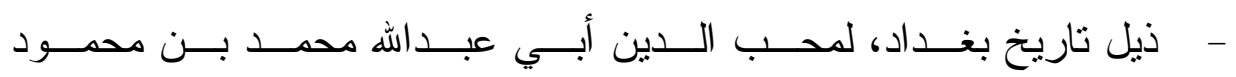

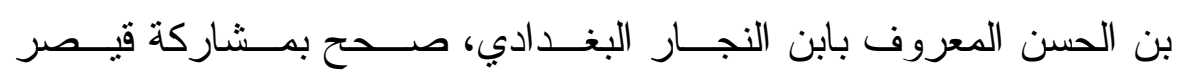
فرح، دار الكتاب العربي بيروت.

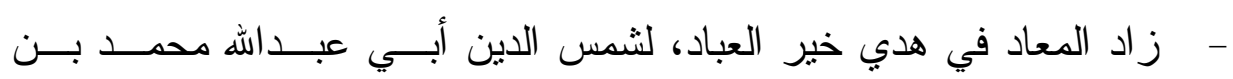

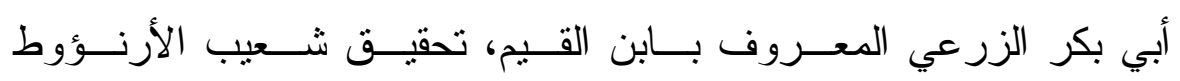

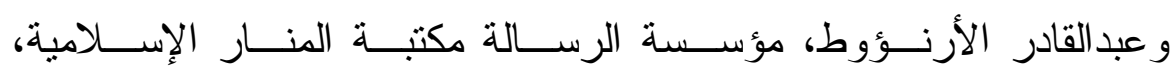

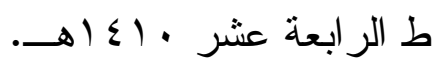

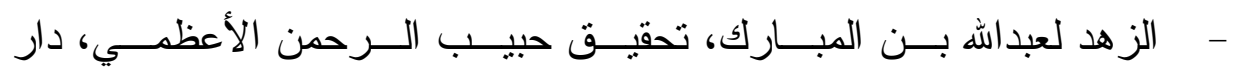
الكتب العلمية بيروت.

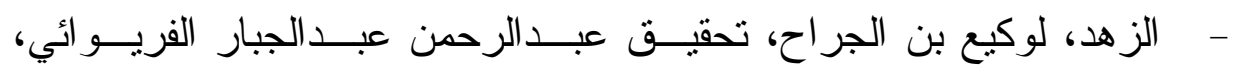

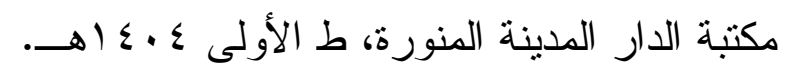
- زو ائد المسند لعبداله بن أحمد= مسند أحمد.

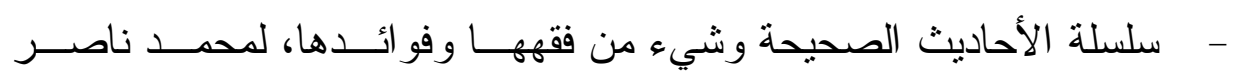
الدين الألباني، مكتبة المعارف الرياض.

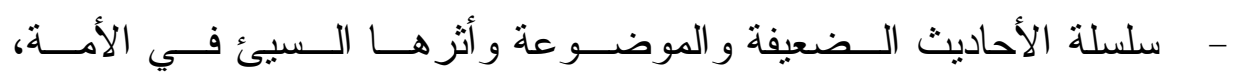
لمحمد ناصر الدين الألباني، مكتبة المعارف الرياض. - السنن الصغرى للبيهقي = مع المنة الكبرى. 
- السنن الكبرى لأبي بكر أحمد بـن الحسسين بــن علـي البيهة يكي، وفـي ذيله الجوهر النقي لعلاء الدين بن علي بــن عثـــان المــارديني الـشهير

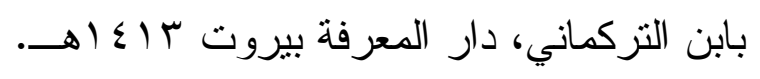

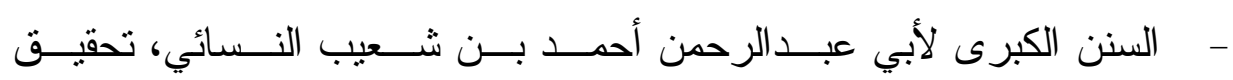
عبدالغفار سليمان البنداري وسيد كـسروي حسـن، دار الكتـبـ العلميــة

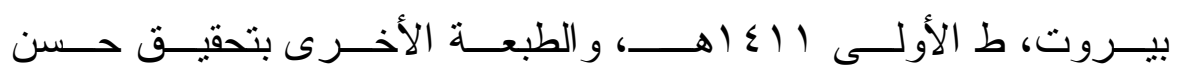

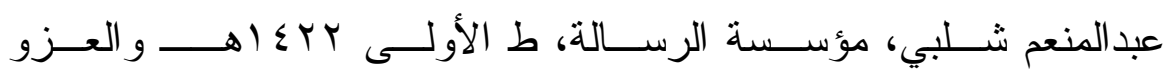
للطبعة الأولى، وللثانية إذا قيدت.

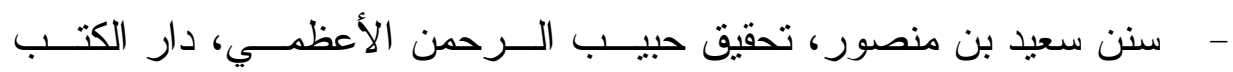

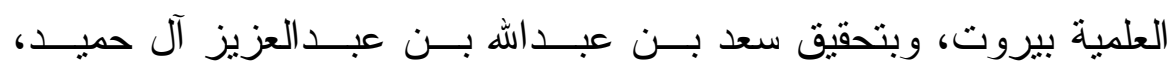

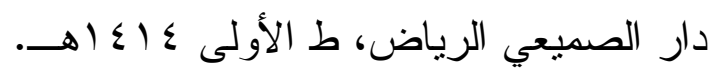

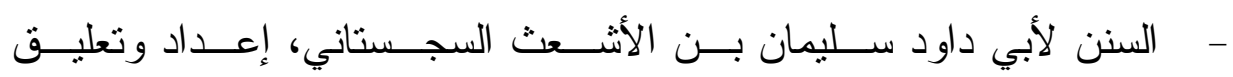
عزت عبيد دعاس، دار الحديث حمص.

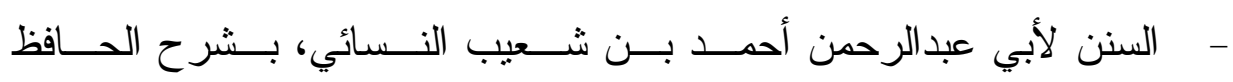

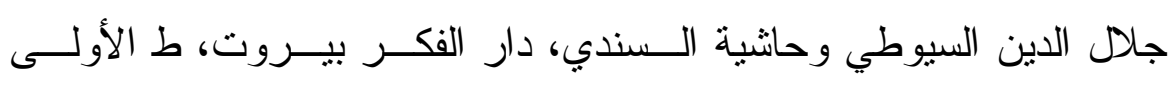
1

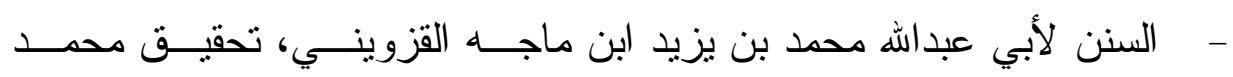
فؤ اد عبدالباقي، دار الحديث القاهرة.

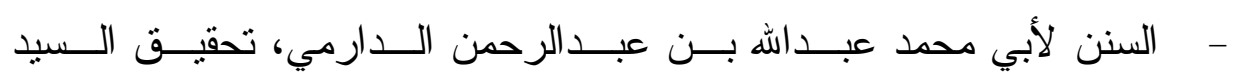

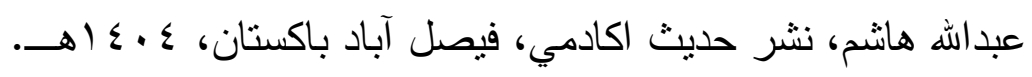

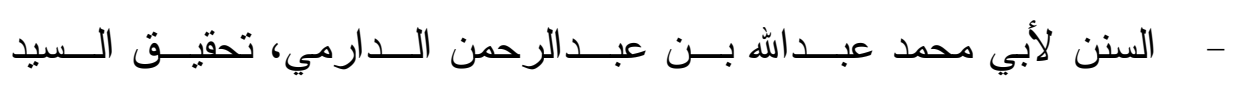

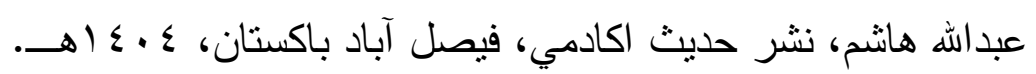




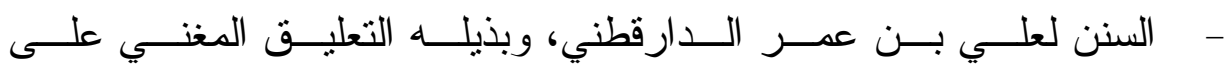

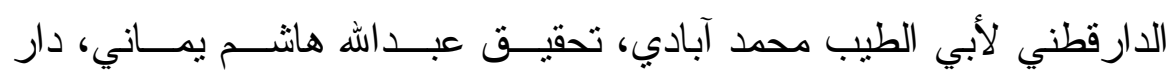

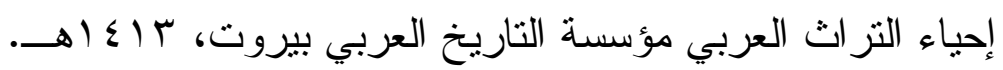

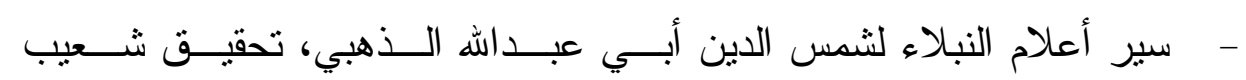

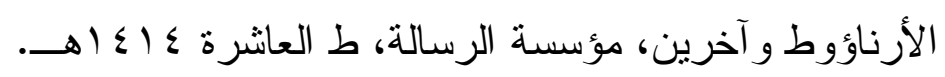

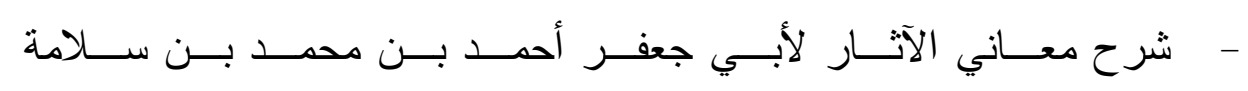

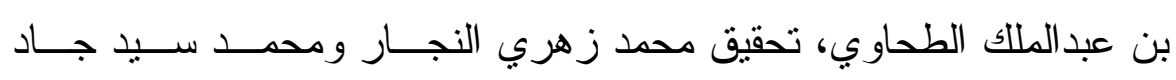

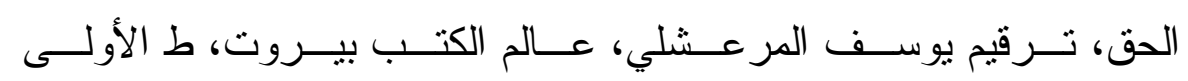
.

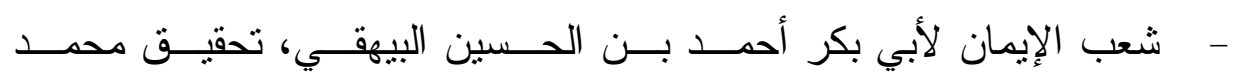

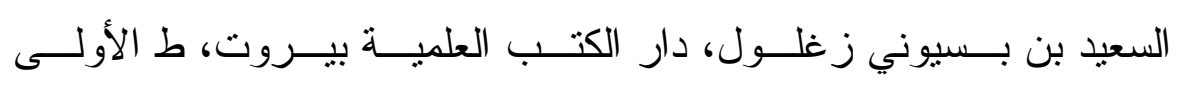
$\rightarrow$. 1 .

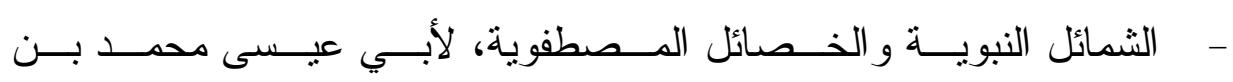
عيسى التزمذي، تحقيق ســبـ بــن عبــاس الحليمـي، مؤســسة الكتهـبـ

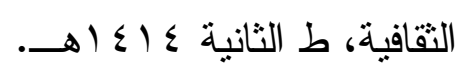
- - صحيح ابن حبان بترنيب ابـن بلبــان عــلاء الــدين علــي بـن بلبــان

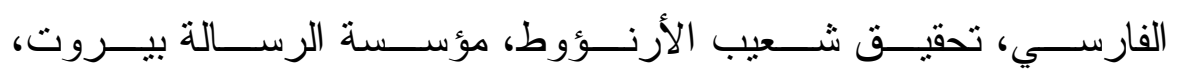

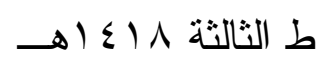

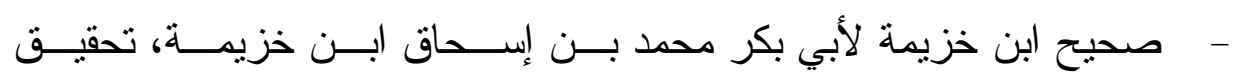

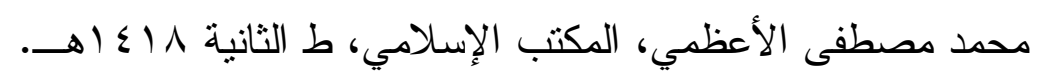

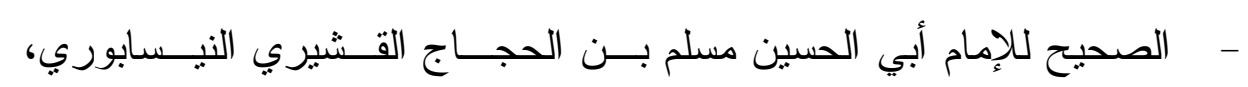
تحقيق محمد فؤاد عبدالباقي، دار إحياء التزاث العربي. 
- - الصحيح للإمام البُخَارِيّ= فتح الباري.

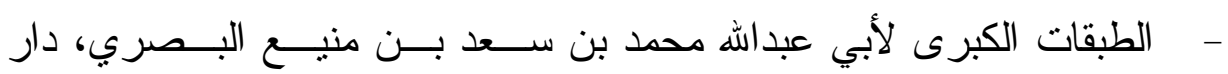
صادر بيروت.

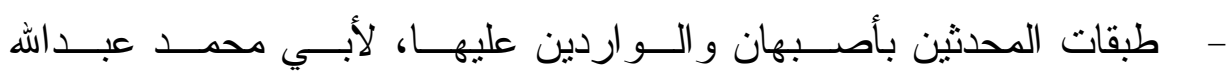

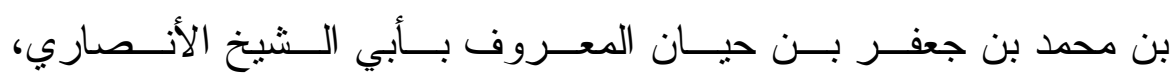

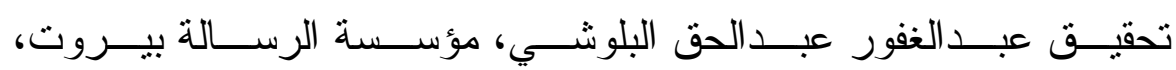

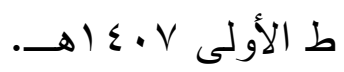
- علل التزمذي الكبير، رتبه على كتـب الجــامع أبــو طالــب القاضــي،

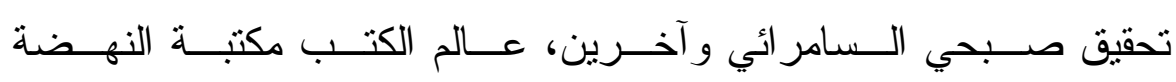

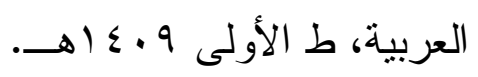
- علل الحديث، لأبي محمد عبد الرحمن بن محمــــــــن إدريـس الـــرازي

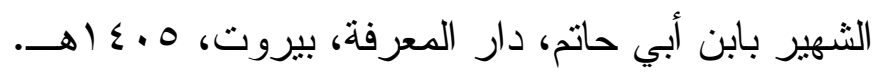

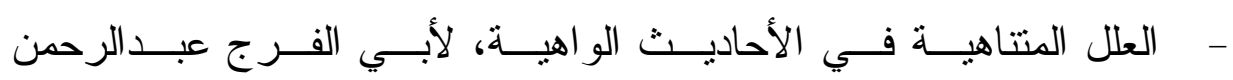

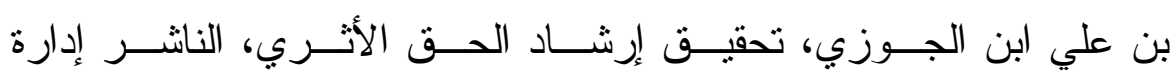

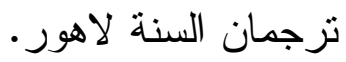

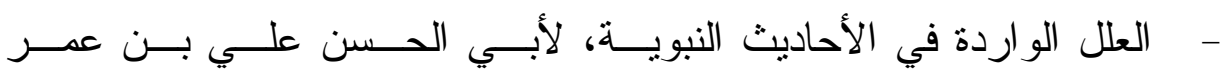
الــدارقطني، تحقيــق محفــوظ الــرحمن زيــن الله الـــلفي، دار طيبــة

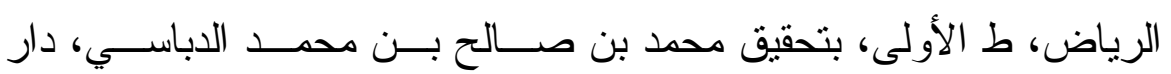

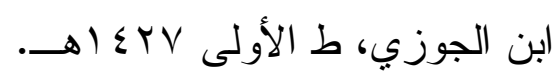

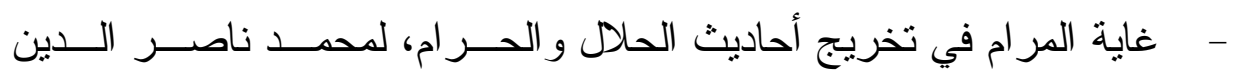

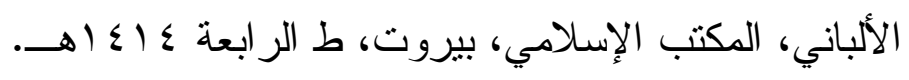


- الغيلانيات، لأبي بكر محمد بن عبداله بــن إبـر اهيم الـشافعي، تحقبــق

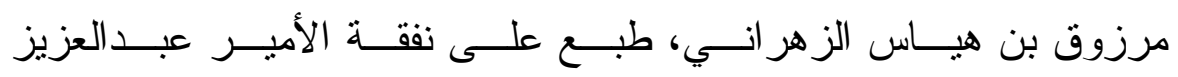

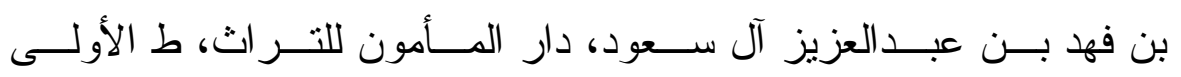
.

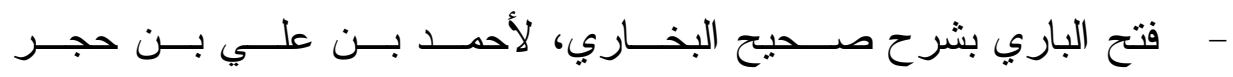
العسقلاني، مصورة عن الطبعة السلفية، مكتبة دار الفيحاء دمشق.

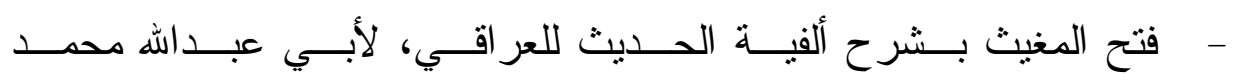

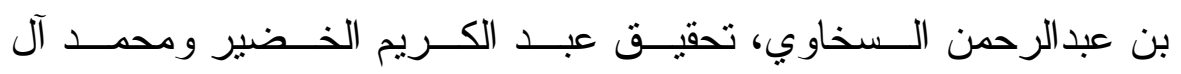

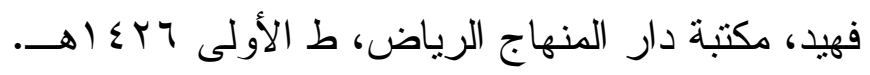

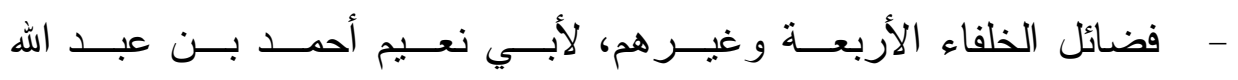

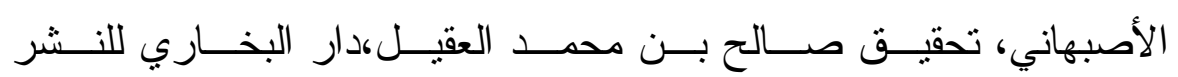
و التوزيع، المدينة، بريدة.

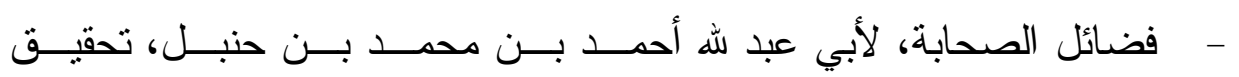

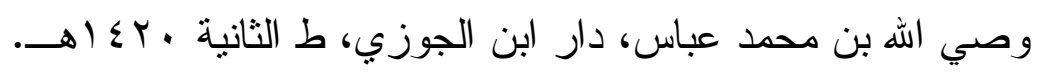

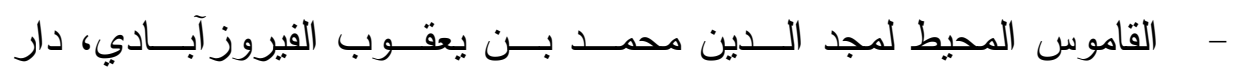

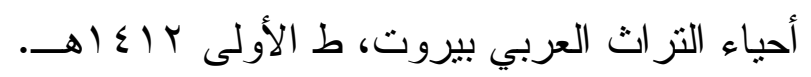

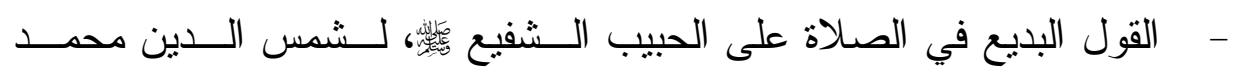
بن عبدالرحمن السخاوي الثافعي، دار الريان للتز اث مصر •

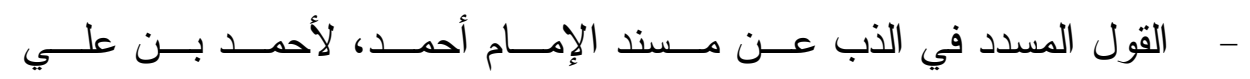

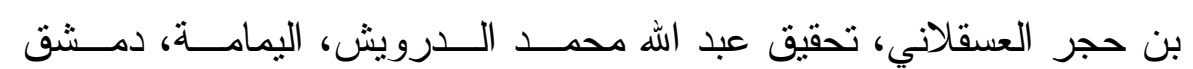

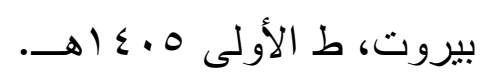


- الكاثف في معرفة من له رواية في الكتب الـستة لأبــي عبــداله محمــد

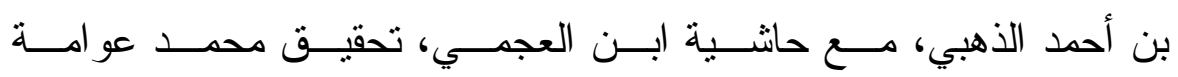

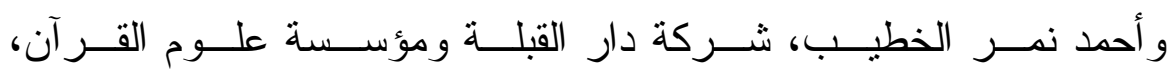

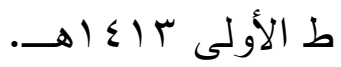

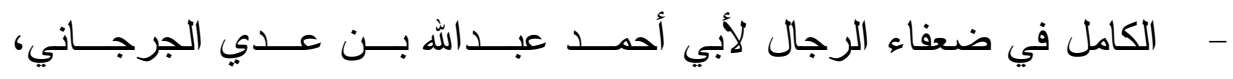

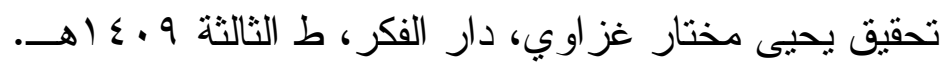

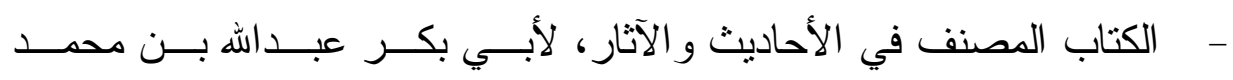

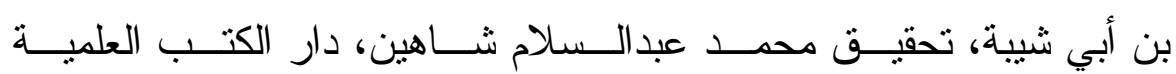

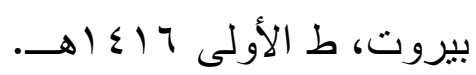
- كثف الأستار عن زوائد البــز ار، لنــور الــدين علــي بــن أبــي بكــر

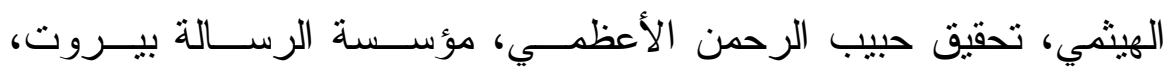

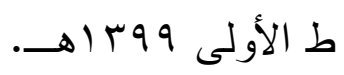
- كثف الخفاء ومزيل الإلباس عما اشــتهر مــن الأحاديــث علــى ألــسنة

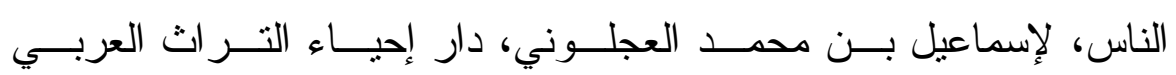

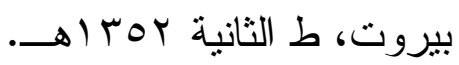

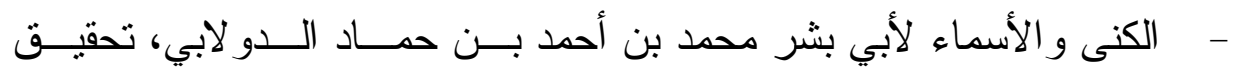

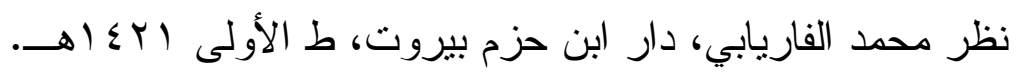

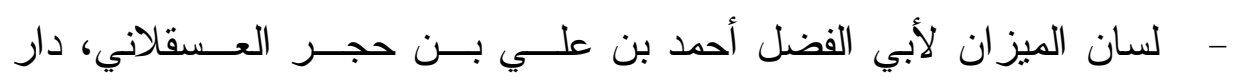

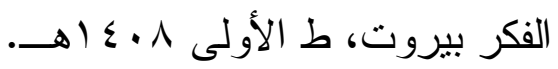

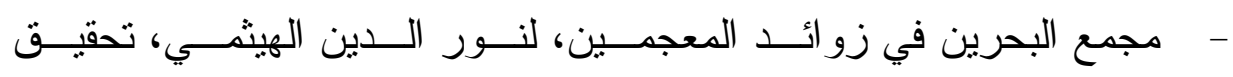

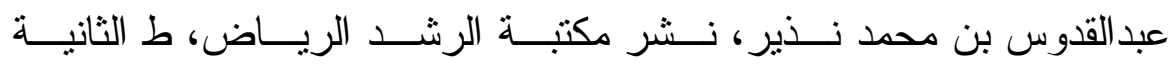
. 1510 
- مجمع الزو ائد ومنبع الفوائد، لنور الدين علي بـن أبــي بكــر الهيثـــي،

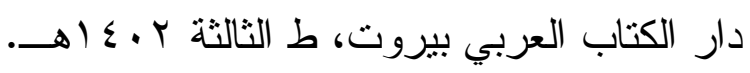

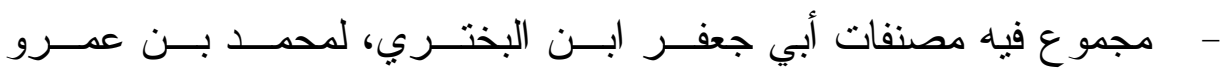

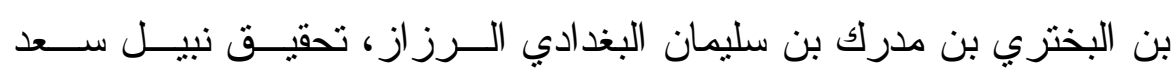

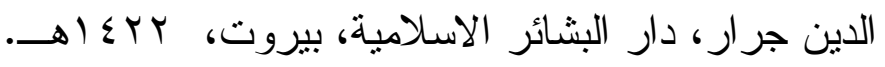
- محاسن الاصطلاح في تـضمين ابــن الـصـلاح، لـسر اج الــدين عمــر

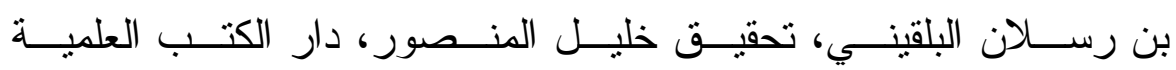

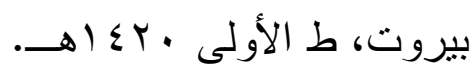
- - المختارة = الأحاديث المختارة.

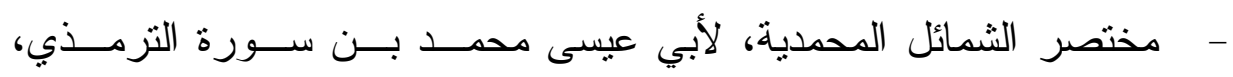

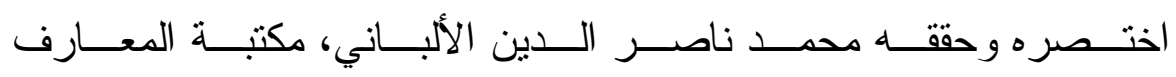

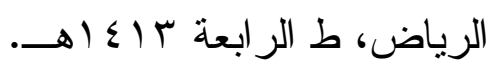

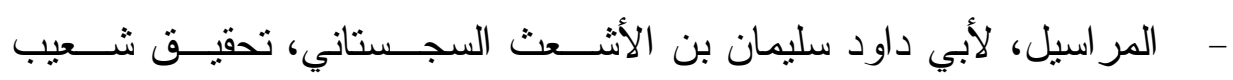

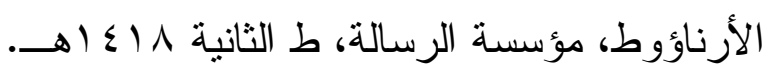

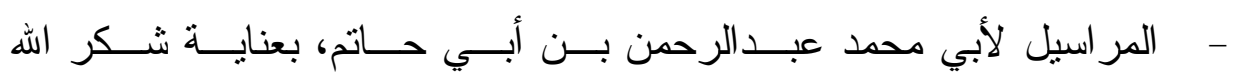

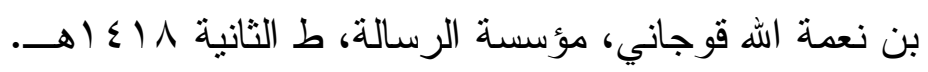

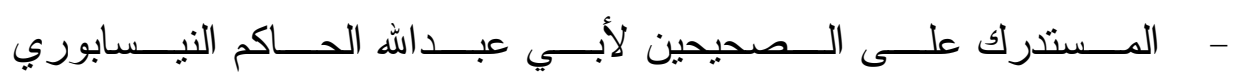

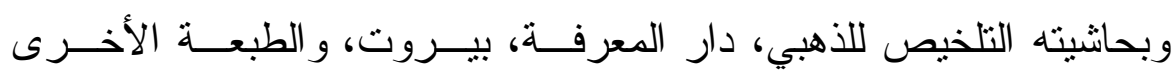

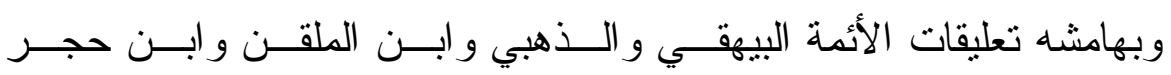

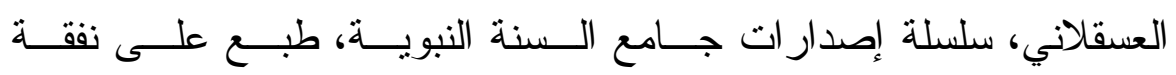

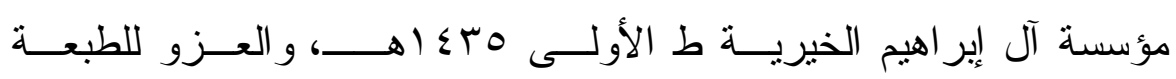
الأولى، وللثانية إذا قيدت. 
- مسند أبــي داود ســليمان بــن داود الطيالـسـي، دار المعرفــة بيـروت.

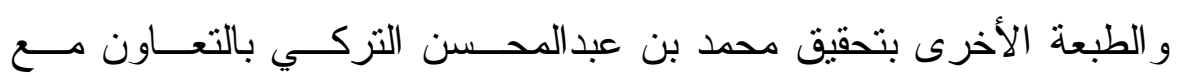

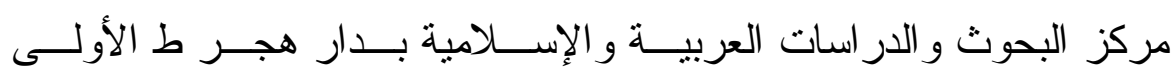
9 إ اهـــ و العزو للطبعة الأولى، وللثانية إذا قيدت.

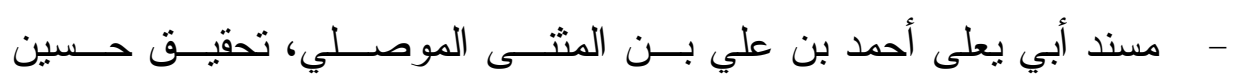

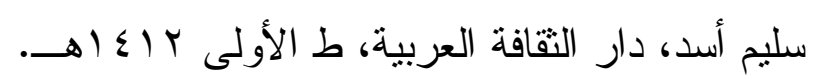

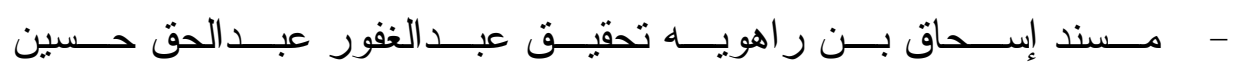

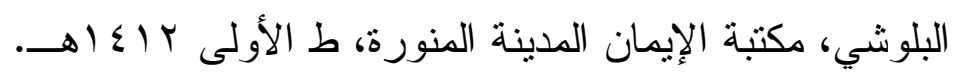

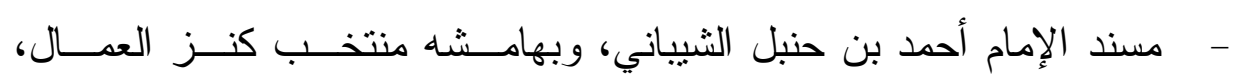

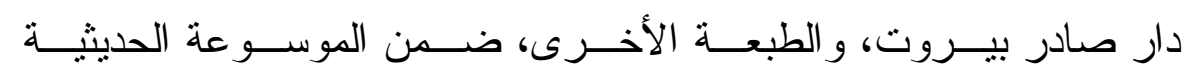

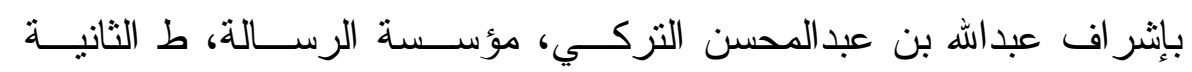
• . أهـ. و العزو للطبعة الأولى، وللثانية إذا قيدت.

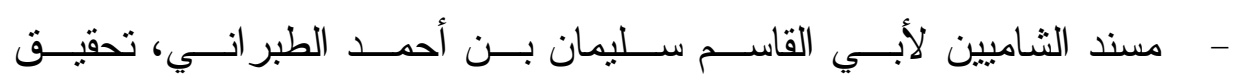

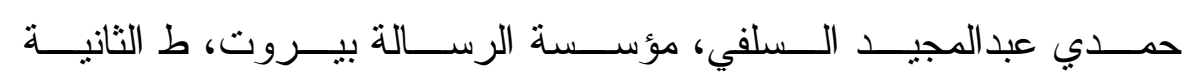
. إV

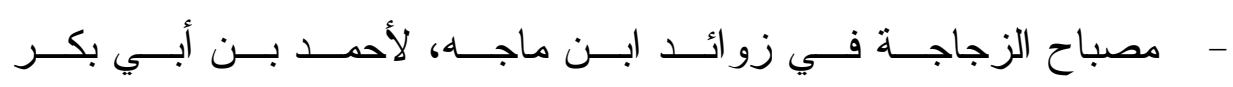

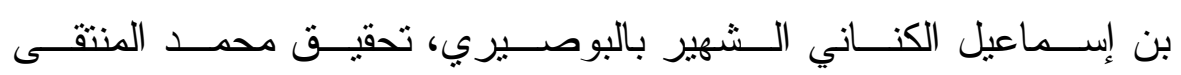

$$
\text { - مصنف ابن أبي شيبة= الكتاب المصنف، دار العربية بيروت، مـ اهــ. }
$$

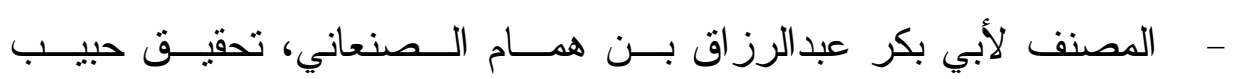

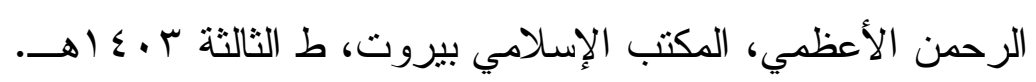




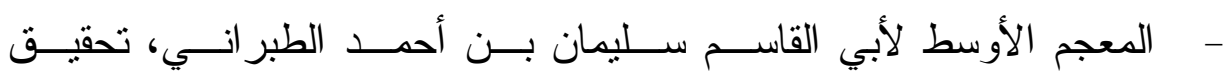

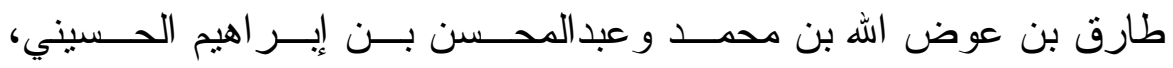

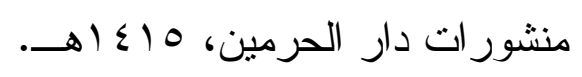

- - المعجم الكبير لأبي القاسم سليمان بن أحمــد الطبر انــي، تحقبــق حمــدي عبدالمجيد السلفي، نشر مكتبة الرشد الرياض، طـ الثانية.

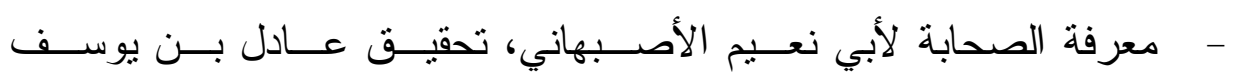

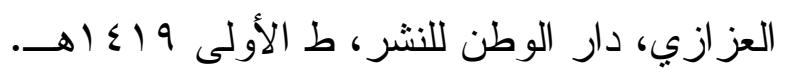

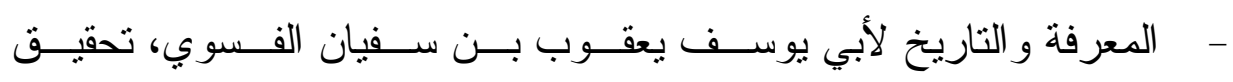

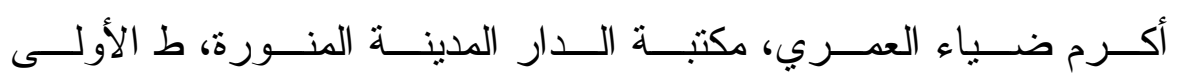
.

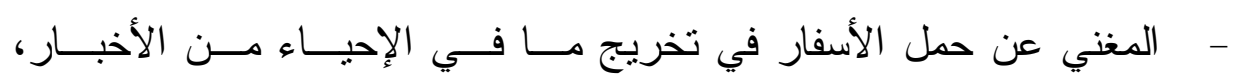

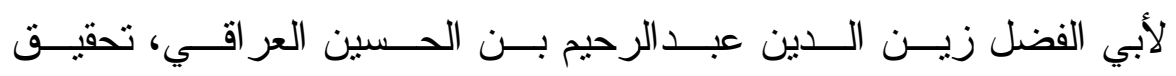

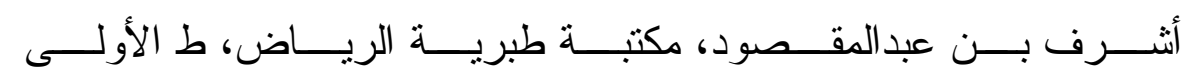
$\rightarrow 1 \leqslant 10$ - المنة الكبرى شرح وتخريج السنن الــصغرى، لمحمــد ضــياء الــرحمن

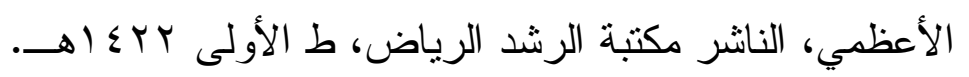

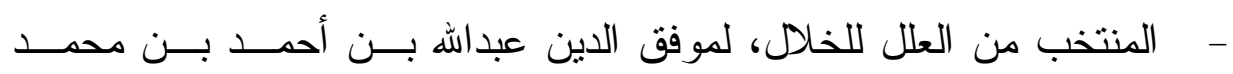

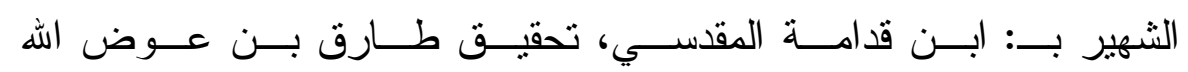

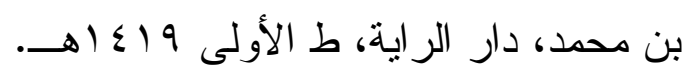

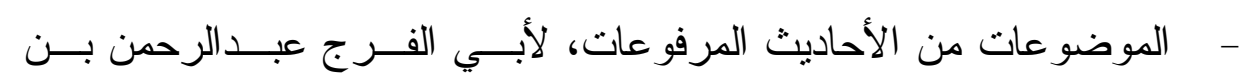
علي ابن الجوزي، تحقيق نور الدين بن شــكري بــن علــي بويــاجيلار،

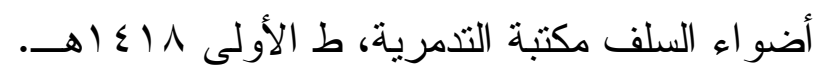




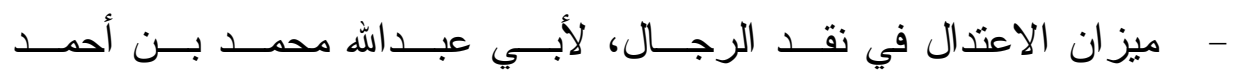

بن عثمان الذهبي، تحقيق علي محمد البجاوي، دار الفكر .

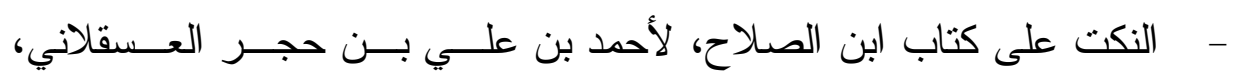
تحقيق ربيــع بـن هــادي عميـر، المجلـس العلمــي إحيــاء التــراث

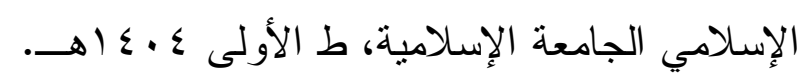

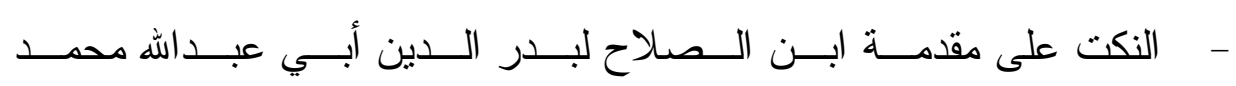
بن جمال الدين بن عبدالله بن بهادر الزركـــي، تحقيــق زيــن العابــدين

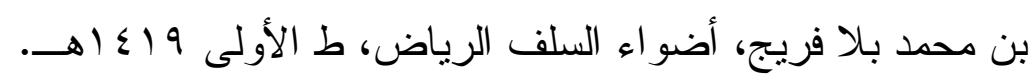

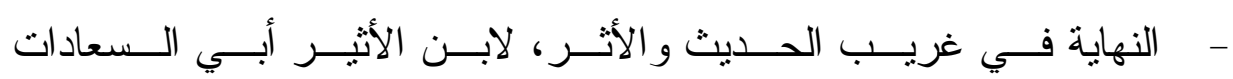

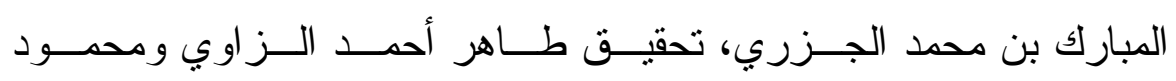
محمد الطناحي، دار الفكر. 
C.94)

- IM 


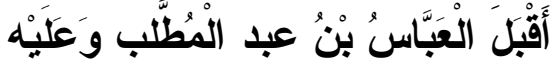

حُلَّةُ وكَلَهُ ضَفِيرَتَان

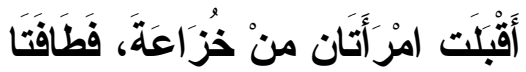

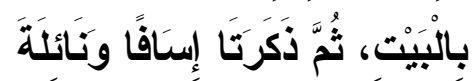

11

أَنَّ أَبَا بَكْرِ كَانَ يُصَلِّي لَهُمْ فِي وَجَع النَّبِّ

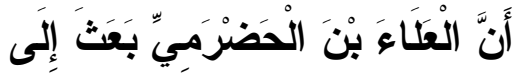

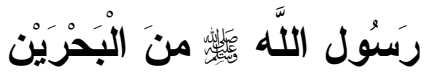

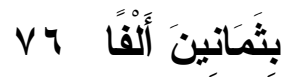

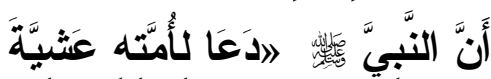

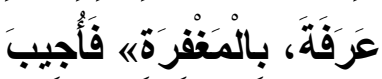

$\mu$.

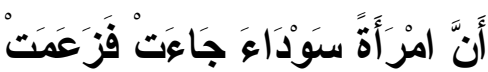

أَنَهَهَا أَرْضَضَعَتْهُمَا،

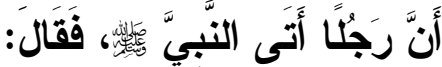

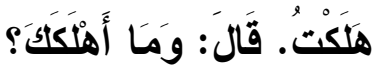

$$
\text { 1० }
$$

أَنَّ رَجْلًا جَاءَ إِلَى النَبي

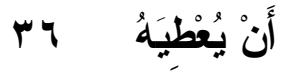

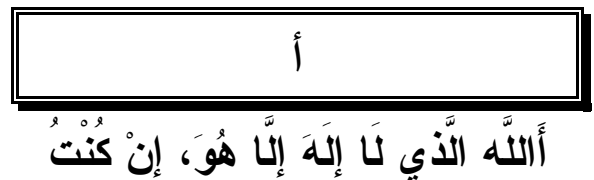

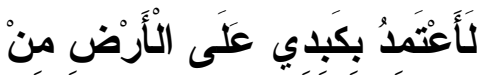

$$
\text { الْجوُعِ، }
$$

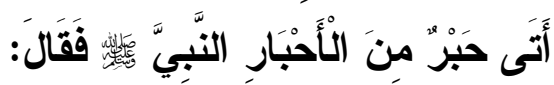

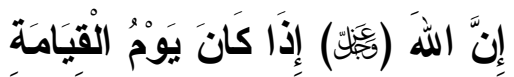

Y

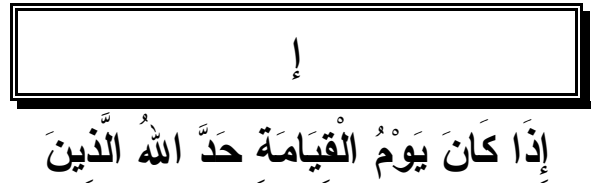

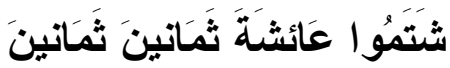

$\bullet \Lambda$

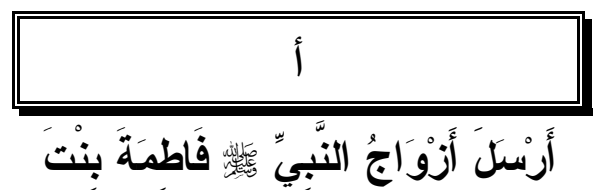

رَسنول الله لهُ

10

أَصَبْتُ جِرَبًَا مِنْ شَحْمِ، يَوْمَ خَيْبرَ هِ

10

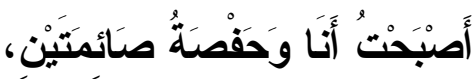

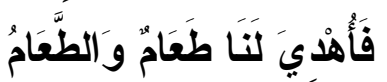

$\wedge 9$ 


\section{$\varphi$}

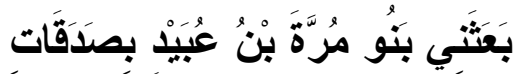

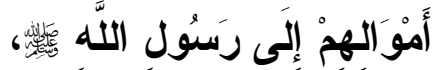

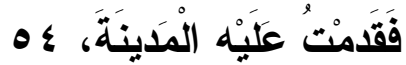

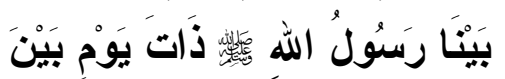

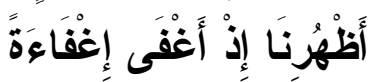

r $\wedge$

بَيْنَمَا نَحْنُ مَعَ رَسَولِ اللَّهِ

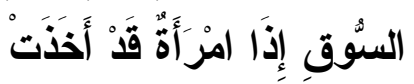

$\Lambda \mathrm{V}$

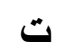

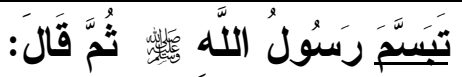

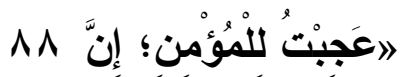

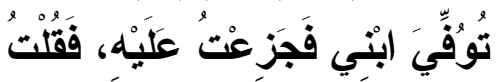

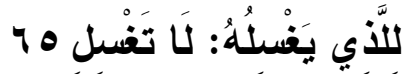

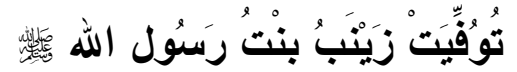

فَخَرَجْنَا مَعَهُ

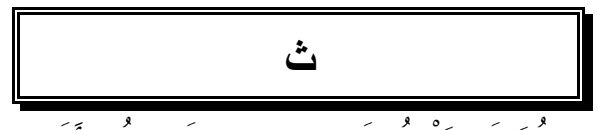

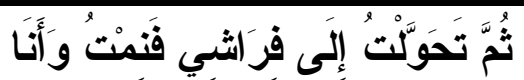

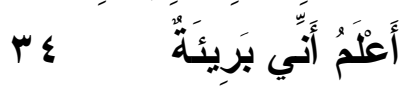

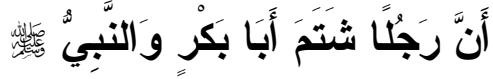

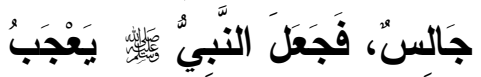

VY

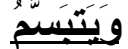

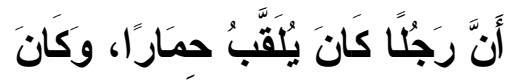

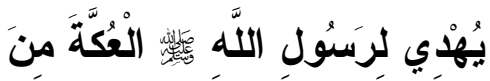

الستَّْن

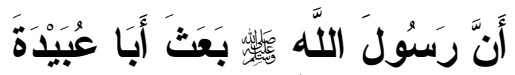

بْنَ الْجَرَّاح إِلَى الََْحْرَيْنِ

$$
\varepsilon
$$

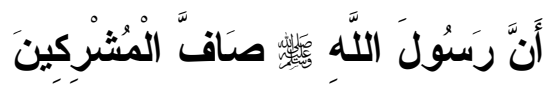

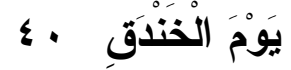

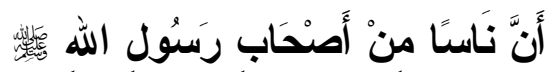

كَاتُوا فِي سَفَرِ

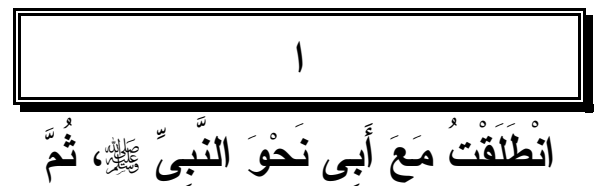

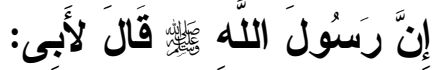

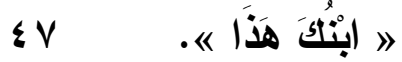

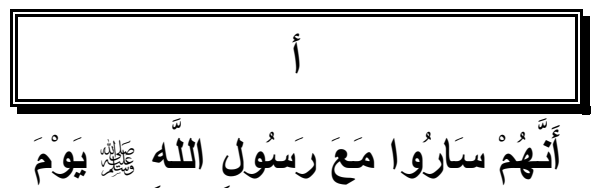

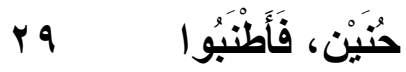


حديث التنوخي رسول هرقل قال:

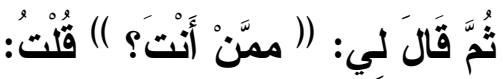

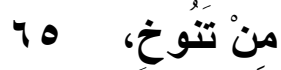

حديث طويل في قصة وفاة زوجها

في الحبشة وزواجها من النبي

$$
\text { ro }
$$

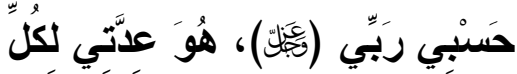

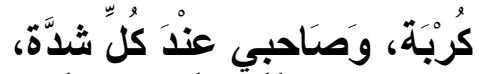

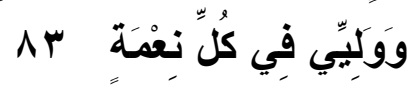

حَضَرْنَاَ مَجْلِسَ مُعَاوِيَة بْنَ أَبِي

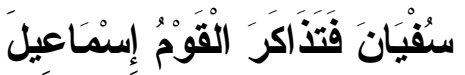

و إِسنحَاقَ بْنَ إِبْرَاهِيمَ

$$
\dot{\tau}
$$

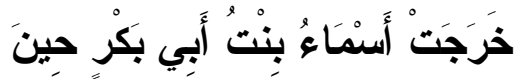

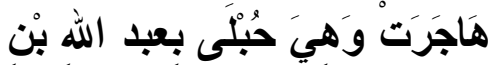

\section{الزَبَيَرْيز}

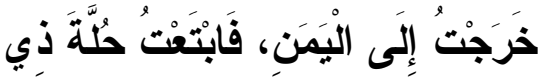

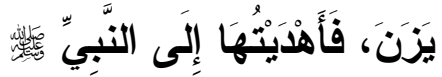

$$
\text { or }
$$

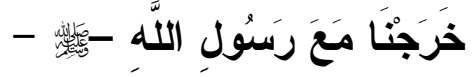

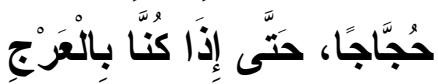

$$
7 \varepsilon
$$

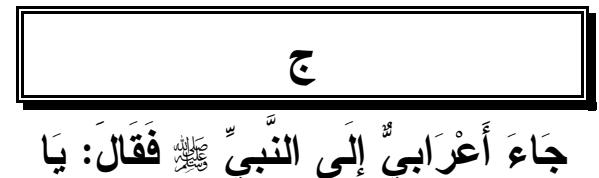

رَسنولَ الله، عَلَّمنْي خَيْرًا

$\vee \wedge$

جَاهَ رَجُلْ إلَّى رَسنُولِ اللهِ

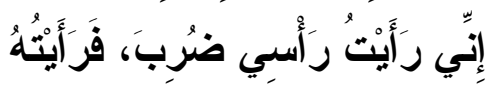

$$
\text { يَتَذَهْدَنُ }
$$

جَاعَتْ امْرَأَةُ رِفَاعَةَ القُرَظِيِّ رَسَوُلَ

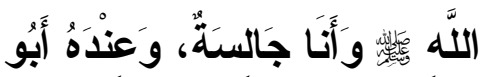

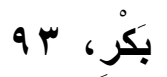

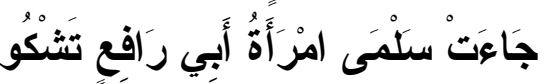
زَوَجْهَا أَبَا رَافِعِ، فَقَالَتْ :

$$
\wedge 7
$$

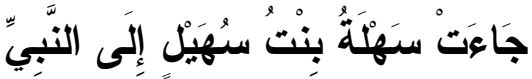

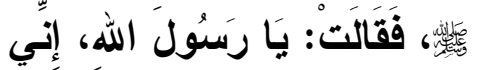

$$
\text { أَرَى فِي وجَجْهِ أَبِي حُنَيَفَةَ }
$$

$$
\text { 10 }
$$

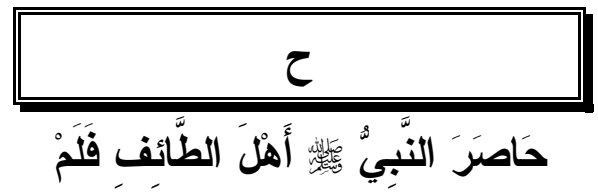

$$
\text { Ir }
$$




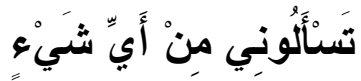

ضَحكتبْهُ،

\section{$\varepsilon$}

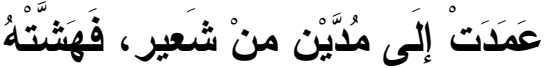

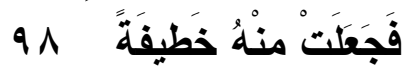

ف

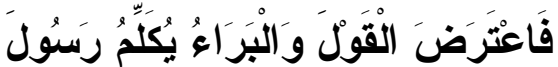
اللهِ

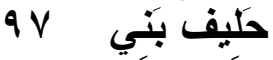

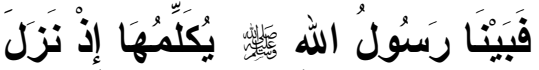

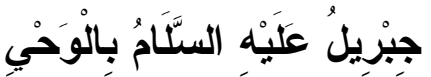

$$
\text { ro }
$$

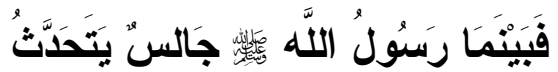

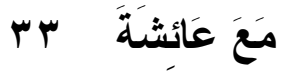

فَجَاعَنِي الرَسَسُولُ ذَاتَ يَوَمْ فَقَالَ: يَاِ

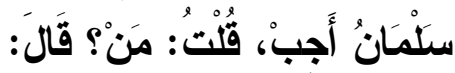

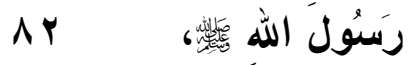

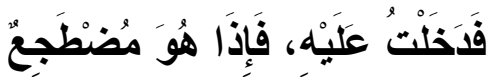

عَلَى رِمَالِ حَصِيرٍ لَيَسنَ بَيْنَهُ

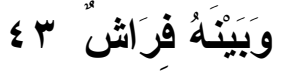

$$
د
$$

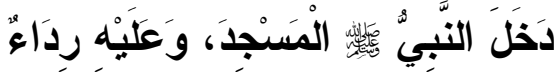

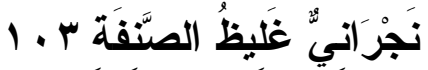

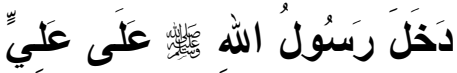

وَفَاطَمَةَ وَهُمَا يضحكَان، فَلَََّّا

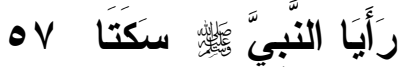

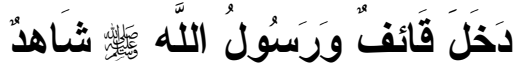

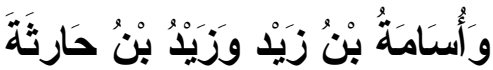

rv مُضْطَجَان

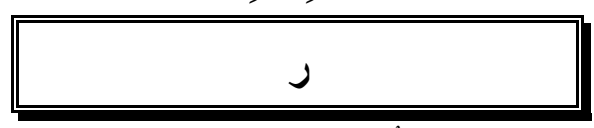

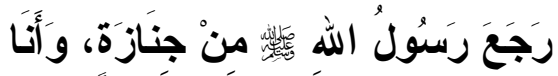

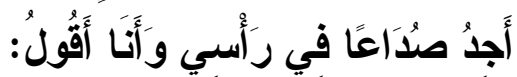
وَارَأُسَاهْ

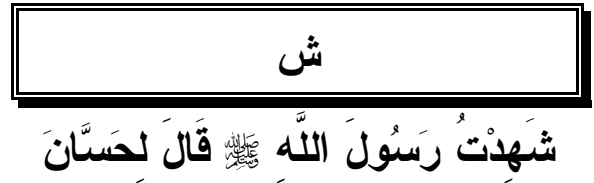

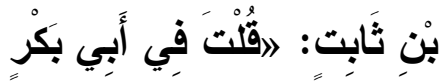

ش ش

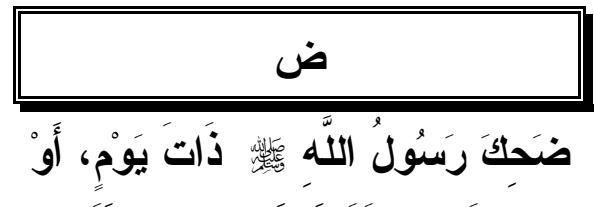

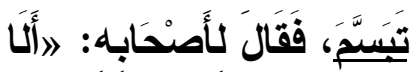


كَانَ فِي سَاقَيْ رَسَولِ اللَّه

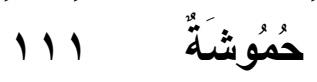

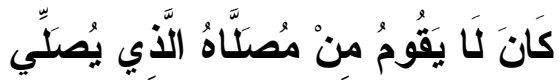

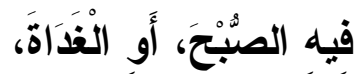

\section{$\leq 7$}

كَانَ يَخْرُجُ عَلَى أَصْحَابِه منَ

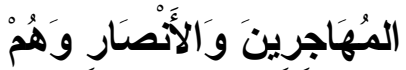

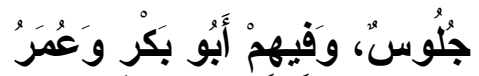
$\bullet$

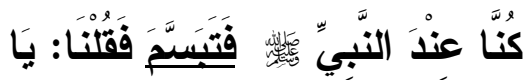

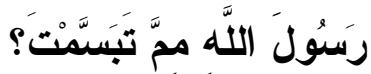

$$
\text { Vr }
$$

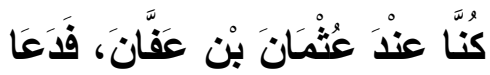

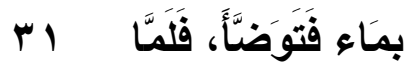

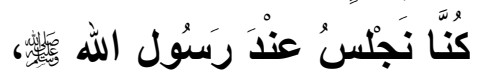

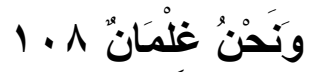

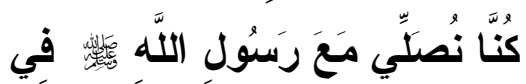

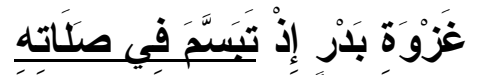

\section{\&}

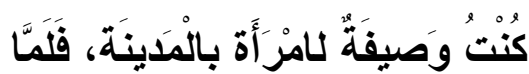

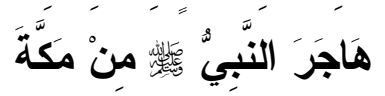

$$
\text { ق }
$$

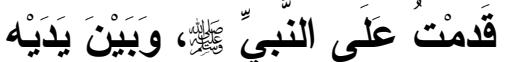

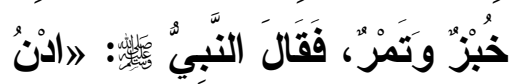

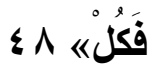

قصة تخلفه ومن معه عن غزوة

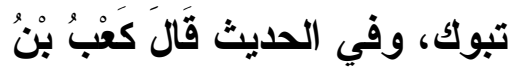

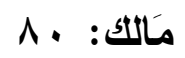

قصة صلح الحديبية، وبعث قريش لعروة بن مسعود الثقفي إلى

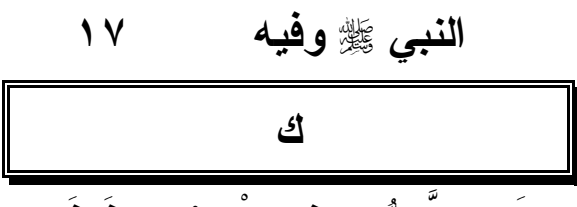

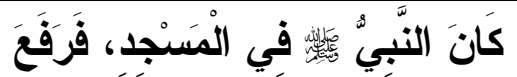

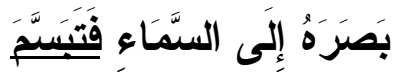

$$
\wedge 1
$$

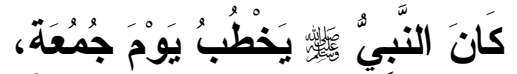

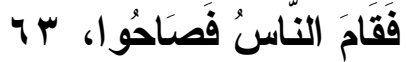

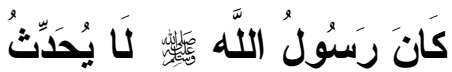

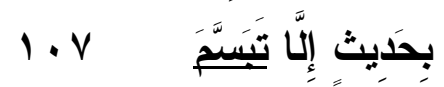

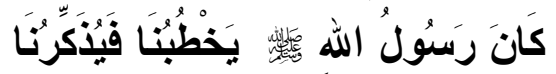

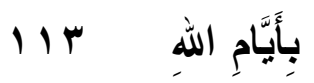


مَنْ يُصَلِّي رَكْعَنَيْن لََا يُحَدِّثُ نَفْسَهُ

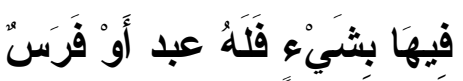
VV

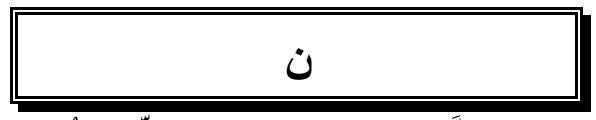

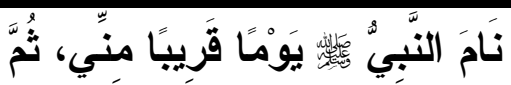

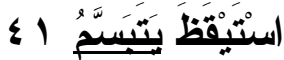

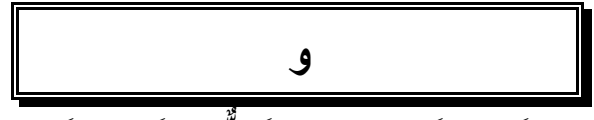

وكَكَانَ مَتَاعَي فيها خَفَ، وكَانَ عَلَّل

جَمَل نَاج، وكَانَ مَتَاعُ صَفِيَّةَ فيه

$$
\text { ثَقَل } 1.1
$$

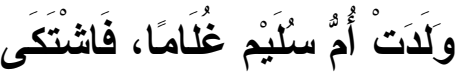

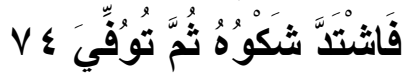

$$
\text { ي }
$$

يَا أَبَا بكرْ تَعَالَ، ويَّا عُمَرُ تَعَالَ،

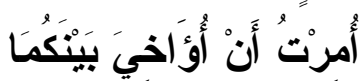

$$
r \text {. }
$$

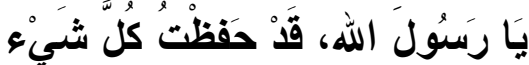

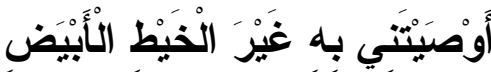

هo

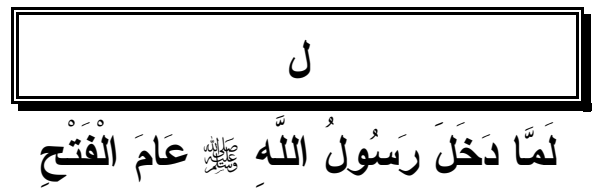

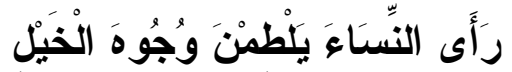

7. بالْخُمُر

لَمَّا مَاتَ عبد اللَّهَ بْنُ أُبَبٍِّ ابْنُ

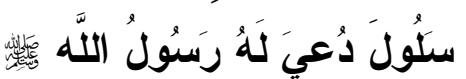

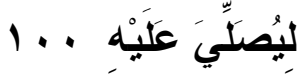

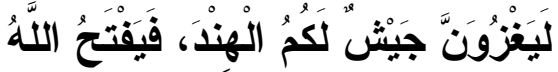

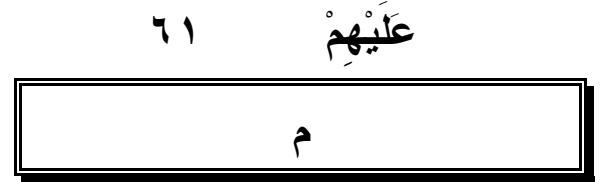

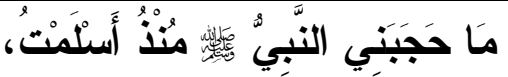

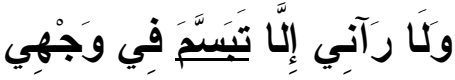

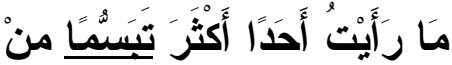
رَسيول الله

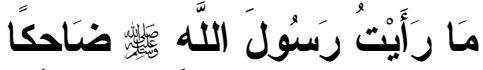

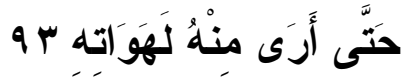

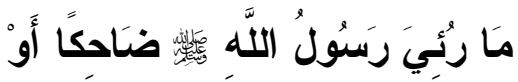

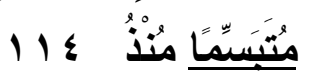

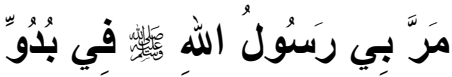

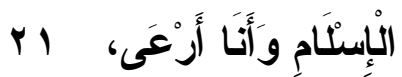




\section{فهرس الموضوعات}

\begin{tabular}{|c|c|}
\hline |لصفحة & الهوضوع \\
\hline$r$ & مقدمة \\
\hline 10 & الرضا و الإقر ار . \\
\hline$r$. & 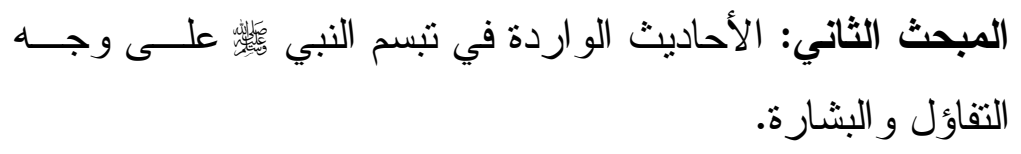 \\
\hline$\varepsilon \mu$ & النصر و التمكين. \\
\hline$\varepsilon 0$ & 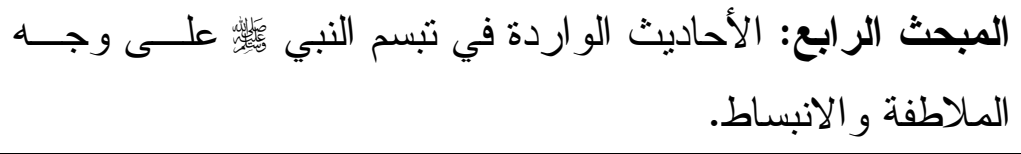 \\
\hline 70 & 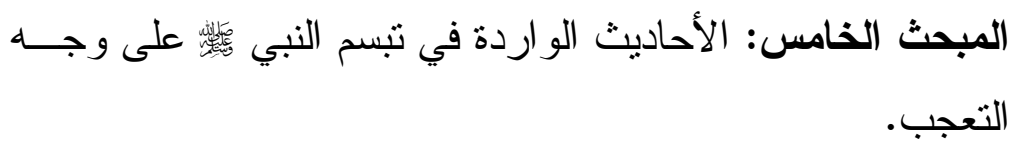 \\
\hline$\Lambda r$ & 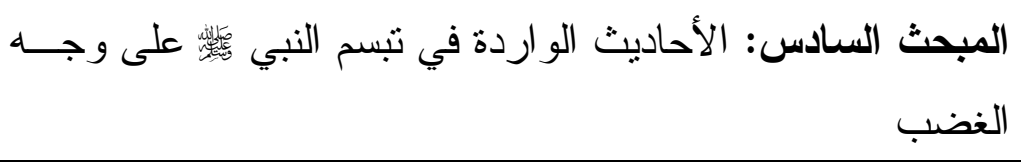 \\
\hline$\Lambda \varepsilon$ & 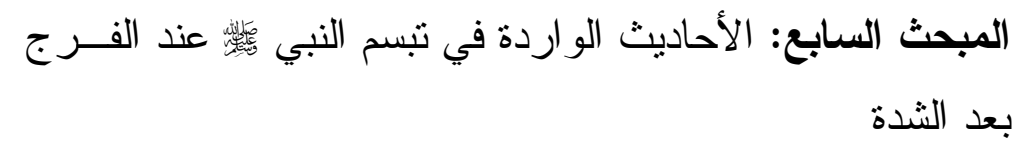 \\
\hline$\Lambda V$ & المبحث الثامن: الأحاديث الو اردة في تبسم النبي ثلئ عند الفتوى أو \\
\hline
\end{tabular}




\section{الأحاديث الواردة في الابتسامة}

\begin{tabular}{|c|c|}
\hline 90 & 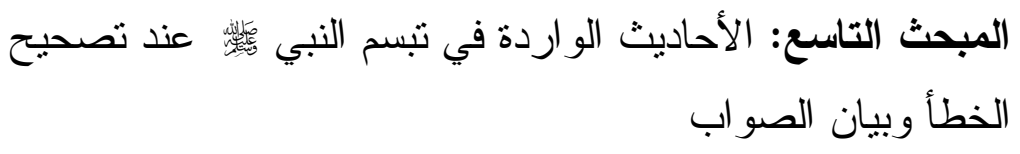 \\
\hline 99 & 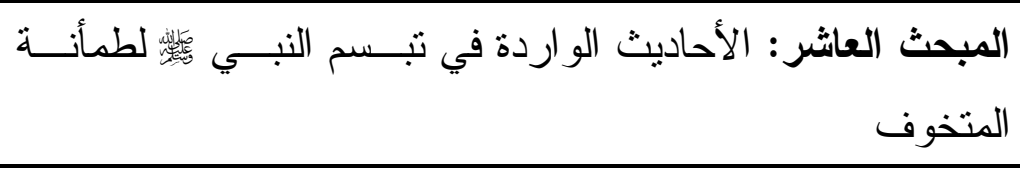 \\
\hline $1 \cdot r$ & 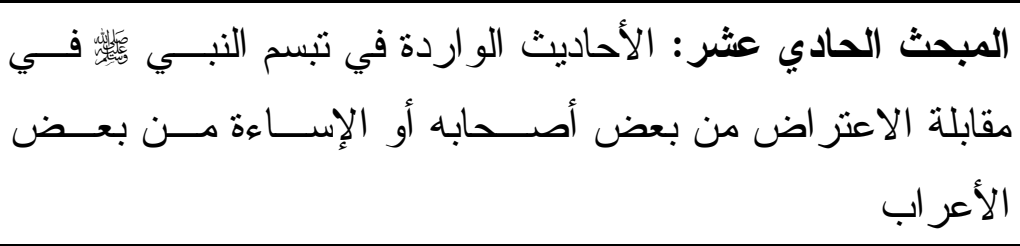 \\
\hline $1 \cdot v$ & 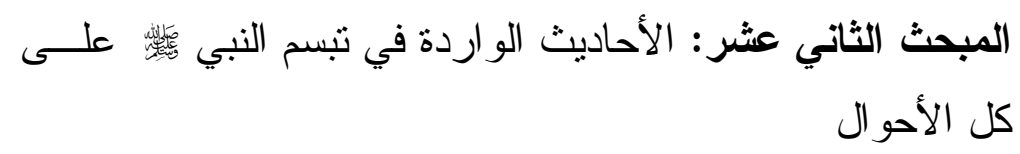 \\
\hline $11 r$ & 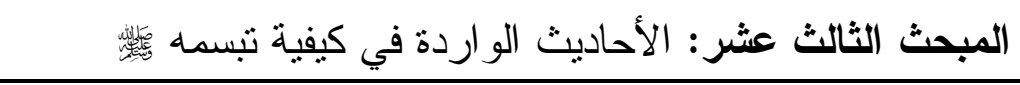 \\
\hline 110 & الخاتمة \\
\hline 111 & ثبث المصادر والمراجع \\
\hline $1 \leq 1$ & فهرس الموضوعات \\
\hline
\end{tabular}

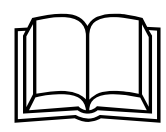

